Prepared in cooperation with the Milwaukee Metropolitan Sewerage District

\title{
Ecological Status of Aquatic Communities in Selected Streams in the Milwaukee Metropolitan Sewerage District Planning Area of Wisconsin, 2004-13
}

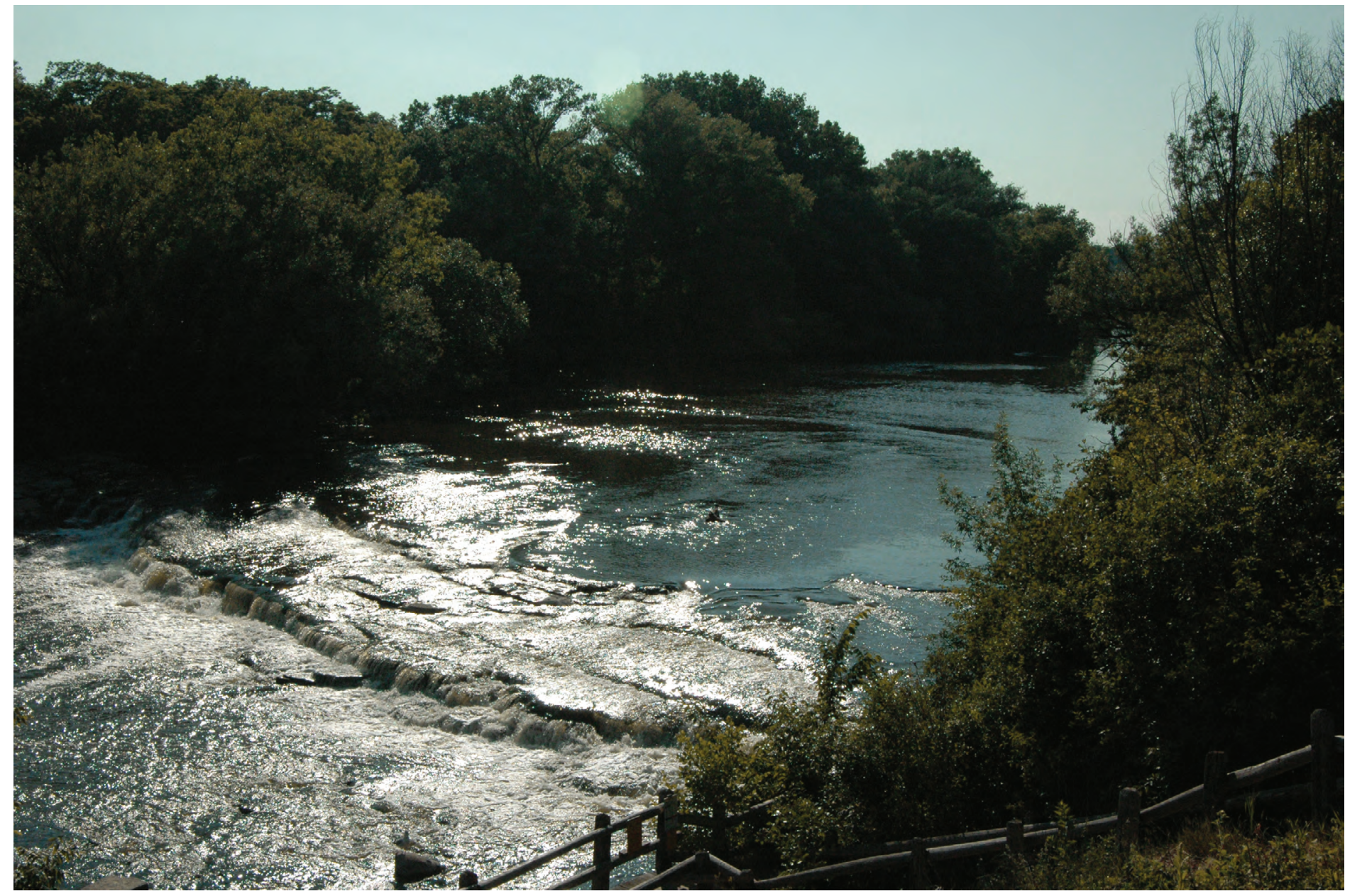

Scientific Investigations Report 2020-5035 
Cover. Photograph showing the Milwaukee River at Milwaukee, Wisconsin (U.S. Geological Survey station 04087000), looking upstream from the falls near the U.S. Geological Survey streamgage in Estabrook Park, taken by Michelle Nott, U.S. Geological Survey, June 23, 2007. 


\section{Ecological Status of Aquatic Communities in Selected Streams in the Milwaukee Metropolitan Sewerage District Planning Area of Wisconsin, 2004-13}

By Barbara C. Scudder Eikenberry, Michelle A. Nott, Jana S. Stewart, Daniel J. Sullivan, David A. Alvarez, Amanda H. Bell, and Faith A. Fitzpatrick

Prepared in cooperation with the Milwaukee Metropolitan Sewerage District

Scientific Investigations Report 2020-5035 


\title{
U.S. Department of the Interior \\ DAVID BERNHARDT, Secretary
}

\author{
U.S. Geological Survey \\ James F. Reilly II, Director
}

U.S. Geological Survey, Reston, Virginia: 2020

For more information on the USGS - the Federal source for science about the Earth, its natural and living resources, natural hazards, and the environment—visit https://www.usgs.gov or call 1-888-ASK-USGS.

For an overview of USGS information products, including maps, imagery, and publications, visit https://store.usgs.gov/.

Any use of trade, firm, or product names is for descriptive purposes only and does not imply endorsement by the U.S. Government.

Although this information product, for the most part, is in the public domain, it also may contain copyrighted materials as noted in the text. Permission to reproduce copyrighted items must be secured from the copyright owner.

Suggested citation:

Scudder Eikenberry, B.C., Nott, M.A., Stewart, J.S., Sullivan, D.J., Alvarez, D.A., Bell, A.H., and Fitzpatrick, F.A., 2020, Ecological status of aquatic communities in selected streams in the Milwaukee Metropolitan Sewerage District planning area of Wisconsin, 2004-13: U.S. Geological Survey Scientific Investigations Report 2020-5035, 84 p., https://doi.org/10.3133/sir20205035.

Associated data for this publication:

Scudder Eikenberry, B.C., Nott, M.A., Stewart, J.S., Sullivan, D.J., Fitzpatrick, F.A., Bell, A.H., and Olds, H.T., 2020, Aquatic community and environmental data for 14 rivers and streams in the Milwaukee Metropolitan Sewerage District Planning Area, 2004-13: U.S. Geological Survey data release, https://doi.org/10.5066/P9FWMODL.

U.S. Geological Survey, 2016, USGS water data for the Nation: U.S. Geological Survey National Water Information System database, https://doi.org/10.5066/F7P55KJN.

ISSN 2328-0328 (online) 


\section{Acknowledgments}

Funding was provided by the Milwaukee Metropolitan Sewerage District (MMSD) with Cooperative Matching Funds by the U.S. Geological Survey (USGS). We thank MMSD employees Chris Magruder, Matt Magruder, Beth Sauer, and Eric Waldmer. Additional thanks to Beth Sauer for providing MMSD water-quality data summaries for ecological sampling years 2004-13.

The Academy of Natural Sciences in Philadelphia, under the supervision of Don Charles and Frank Acker, identified and counted algal taxa. The Aquatic Biomonitoring Laboratory at the University of Wisconsin-Stevens Point (Stevens Point, Wisconsin), under the supervision of Stanley Szcztyko and Jeffrey Dimick, identified and counted invertebrate taxa. Semipermeable membrane device dialyses and extract preparations were done by Terri Spencer with EST Labs, St. Joseph, Missouri; the USGS Columbia Environmental Research Center completed Microtox and Fluoroscan tests on extracts; David R. Johnson and Choo Yaw Ang completed cytochromeP450 reporter gene system toxicity tests on semipermeable membrane device extracts at the U.S. Army Corps of Engineers, Engineer Research and Development Center-Waterways Experiment Station in Vicksburg, Mississippi.

Many USGS employees assisted with data collection over the years, including Austin K. Baldwin, Cheryl A. Buchwald, Nicolas H. Buer, Dean Burdett, Daniel J. Burns, Rebecca B. Carvin, Mitchell A. Harris, Jennifer L. Hogan, Krista A. Hood, Ryan T. Jirik, Leah E. Kammel, James L. Kennedy, Bernard N. Lenz, S. Bridgett Manteufel, Kassidy T. Mapel, Hayley T. Olds, Mark L. Olson, Kevin D. Richards, Laura L. Rozamulski, David A. Saad, Denis P. Scanlan, Jeffery J. Steuer, Judith C. Thomas, Rebecca H. Woll, and Benjamin M. Young. Kassidy T. Mapel also assisted with compilation of water-quality data, and Hayley T. Olds also computed light extinction coefficients. Daren M. Carlisle computed additional invertebrate metrics. Jessica L. Thompson computed annual discharge metrics from USGS streamgage data. Sara B. Levin and Edward G. Dobrowolski provided technical comments, and Janet M. Carter provided technical and editorial comments on an earlier version of the report. 



\section{Contents}

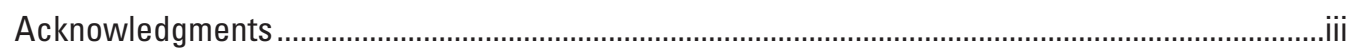

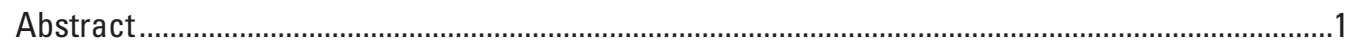

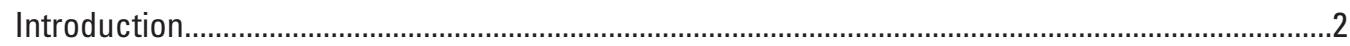

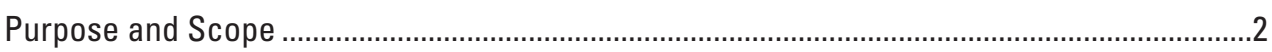

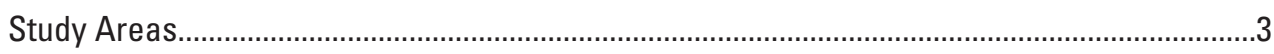

Methods

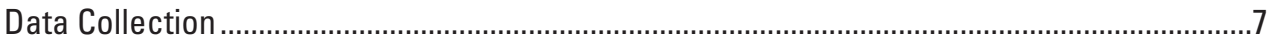

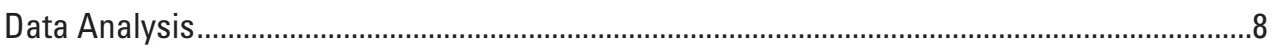

Assessment of Aquatic Communities in Relation to Stream Condition ............................................10

Comparative Bioassessment across Sampled Streams ........................................................10

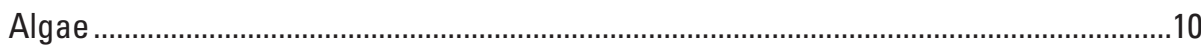

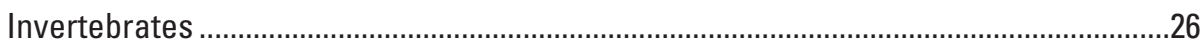

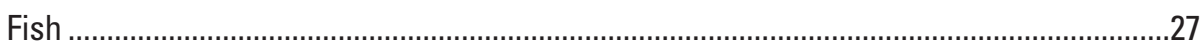

Comparative Bioassessment among Algae, Invertebrates, and Fish .......................................49

Physical and Chemical Stressors at Sampled Sites ..........................................................49

Toxicity and Chemical Assessment with Passive Sampling Devices .............................49

Relations between Biological Metrics and Environmental Stressors .............................52

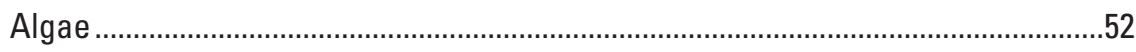

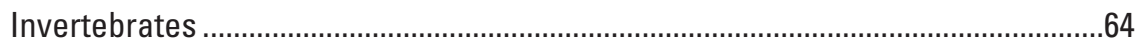

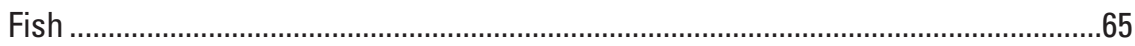

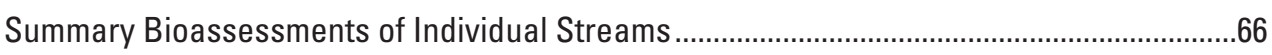

Milwaukee River near Cedarburg ..........................................................................66

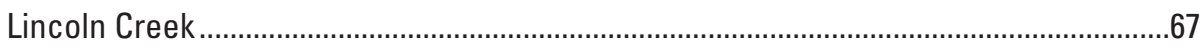

Milwaukee River at Milwaukee.................................................................................68

Willow Creek

Menomonee River at Menomonee Falls .......................................................................

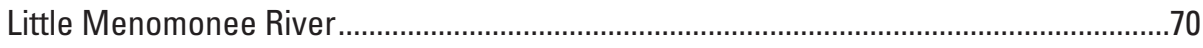

Underwood Creek ……................................................................................................

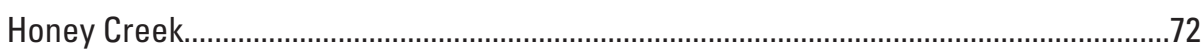

Menomonee River at Wauwatosa ................................................................................

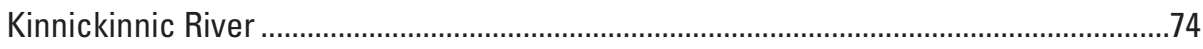

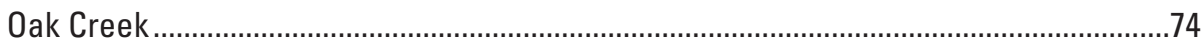

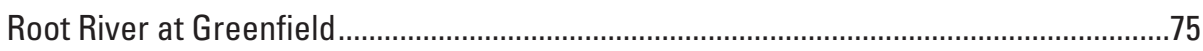

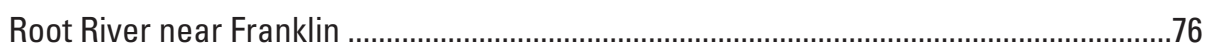

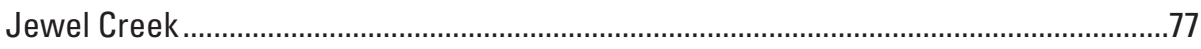

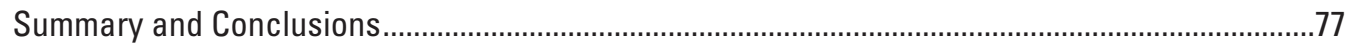

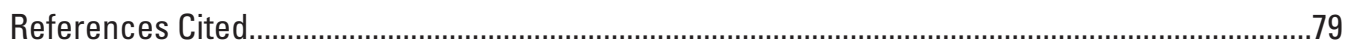




\section{Figures}

1. Map showing sites where biological assessments were completed in 2004-13 in the Milwaukee Metropolitan Sewerage District planning area of Wisconsin . . .4

2. Multidimensional scaling ordination plot for algal assemblages collected at 14 sites in the Milwaukee area, Wisconsin, 2004-13

3. Bar plots showing selected algal metrics for each of 14 stream sites in the Milwaukee area, Wisconsin, 2004-13.

4. Map showing pollution-sensitive diatom algae scores at 14 stream sites in the Milwaukee area, Wisconsin, 2004-13.

5. Multidimensional scaling ordination plot for invertebrate assemblages collected at 14 sites in the Milwaukee area, Wisconsin, 2004-13

6. Bar plots showing selected invertebrate metrics for each of the 14 stream sites in the Milwaukee area, Wisconsin, 2004-13.

7. Map showing invertebrate Hilsenhoff Biotic Index scores, modified to limit the number of individuals per taxon to 10 for index computation, for fall samples at 14 stream sites in the Milwaukee Metropolitan Sewerage District planning area, Wisconsin, 2004-13

8. Multidimensional scaling ordination plot for fish assemblages collected at 14 sites in the Milwaukee area, Wisconsin, 2004-13

9. Bar plots showing selected fish metrics for each of the 14 stream sites in the Milwaukee area, Wisconsin, 2004-13

10. Map showing fish Index of Biotic Integrity scores for fall samples at 14 stream sites in the Milwaukee Metropolitan Sewerage District planning area, Wisconsin, 2004-13

11. Graphs showing relations between algal metrics and environmental metrics for 14 streams in the Milwaukee area, Wisconsin, 2004-13

12. Graphs showing relations between invertebrate metrics and environmental metrics for 14 streams in the Milwaukee area, Wisconsin, 2004-13..

13. Graphs showing relations between fish metrics and environmental metrics for 14 streams in the Milwaukee area, Wisconsin, 2004-13

\section{Tables}

1. U.S. Geological Survey stream sites where biological assessments were completed in 2004-13 in the Milwaukee Metropolitan Sewerage District planning area of Wisconsin, showing drainage area.

2. Algal-assemblage information from surveys completed in 2004, 2007, 2010, and 2013 at 14 stream sites in the Milwaukee Metropolitan Sewerage District planning area, Wisconsin..

3. Comparison of algal-assemblage data at 14 stream sites in the Milwaukee Metropolitan Sewerage District planning area, Wisconsin, 2004-13.

4. Water-quality ratings for the invertebrate Hilsenhoff Biotic Index and macroinvertebrate Index of Biotic Integrity for streams

5. Comparison of invertebrate-assemblage data at 14 stream sites in the

Milwaukee Metropolitan Sewerage District planning area, Wisconsin, 2004-13. 
6. Scores and ratings for the fish Index of Biotic Integrity for warmwater streams...........38

7. Comparison of fish-assemblage data at 14 stream sites in the Milwaukee Metropolitan Sewerage District planning area, Wisconsin, 2004-13............................39

8. Mean trophic-level rankings and aggregate bioassessment rankings for 14 stream sites in the Milwaukee area, Wisconsin, 2013 and 2004

9. Results for toxicity tests and selected chemical analyses of passive sampling devices deployed at 10 of 14 sites in the Milwaukee area, Wisconsin, 2004-13............51

10. Summary of environmental metrics correlated to metrics for algae, invertebrates, and (or) fish in streams of the Milwaukee Metropolitan Sewerage District planning area of Wisconsin, 2004-13

\section{Conversion Factors}

U.S. customary units to International System of Units

\begin{tabular}{|c|c|c|}
\hline Multiply & By & To obtain \\
\hline \multicolumn{3}{|c|}{ Length } \\
\hline inch (in) & 2.54 & centimeter $(\mathrm{cm})$ \\
\hline inch (in) & 25.4 & millimeter (mm) \\
\hline mile (mi) & 1.609 & kilometer $(\mathrm{km})$ \\
\hline \multicolumn{3}{|c|}{ Area } \\
\hline square mile $\left(\mathrm{mi}^{2}\right)$ & 2.590 & square kilometer $\left(\mathrm{km}^{2}\right)$ \\
\hline \multicolumn{3}{|c|}{ Flow rate } \\
\hline cubic foot per second $(\mathrm{ft} 3 / \mathrm{s})$ & 0.02832 & cubic meter per second $\left(\mathrm{m}^{3} / \mathrm{s}\right)$ \\
\hline
\end{tabular}

International System of Units to U.S. customary units

\begin{tabular}{|c|c|c|}
\hline Multiply & By & To obtain \\
\hline \multicolumn{3}{|c|}{ Length } \\
\hline centimeter $(\mathrm{cm})$ & 0.3937 & inch (in) \\
\hline meter (m) & 3.281 & foot $(\mathrm{ft})$ \\
\hline liter (L) & 1.057 & quart (qt) \\
\hline liter (L) & 0.2642 & gallon (gal) \\
\hline \multicolumn{3}{|c|}{ Area } \\
\hline square centimeter $\left(\mathrm{cm}^{2}\right)$ & 0.001076 & square foot $\left(\mathrm{ft}^{2}\right)$ \\
\hline square centimeter $\left(\mathrm{cm}^{2}\right)$ & 0.1550 & square inch $\left(\mathrm{ft}^{2}\right)$ \\
\hline
\end{tabular}

Temperature in degrees Celsius $\left({ }^{\circ} \mathrm{C}\right)$ may be converted to degrees Fahrenheit $\left({ }^{\circ} \mathrm{F}\right)$ as ${ }^{\circ} \mathrm{F}=\left(1.8 \times{ }^{\circ} \mathrm{C}\right)+32$. 


\section{Supplemental Information}

Specific conductance is given in microsiemens per centimeter at 25 degrees Celsius $(\mu \mathrm{S} / \mathrm{cm}$ at $\left.25^{\circ} \mathrm{C}\right)$.

Concentrations of chemical constituents in water are given in milligrams per liter (mg/L), micrograms per liter ( $\mu \mathrm{g} / \mathrm{L})$, or nanograms per liter (ng/L).

A water year is the 12-month period from 0ctober 1 to September 30 and is designated by the year in which it ends; for example, water year 2015 was from 0 ctober 1, 2014, to September 30, 2015.

\section{Abbreviations}

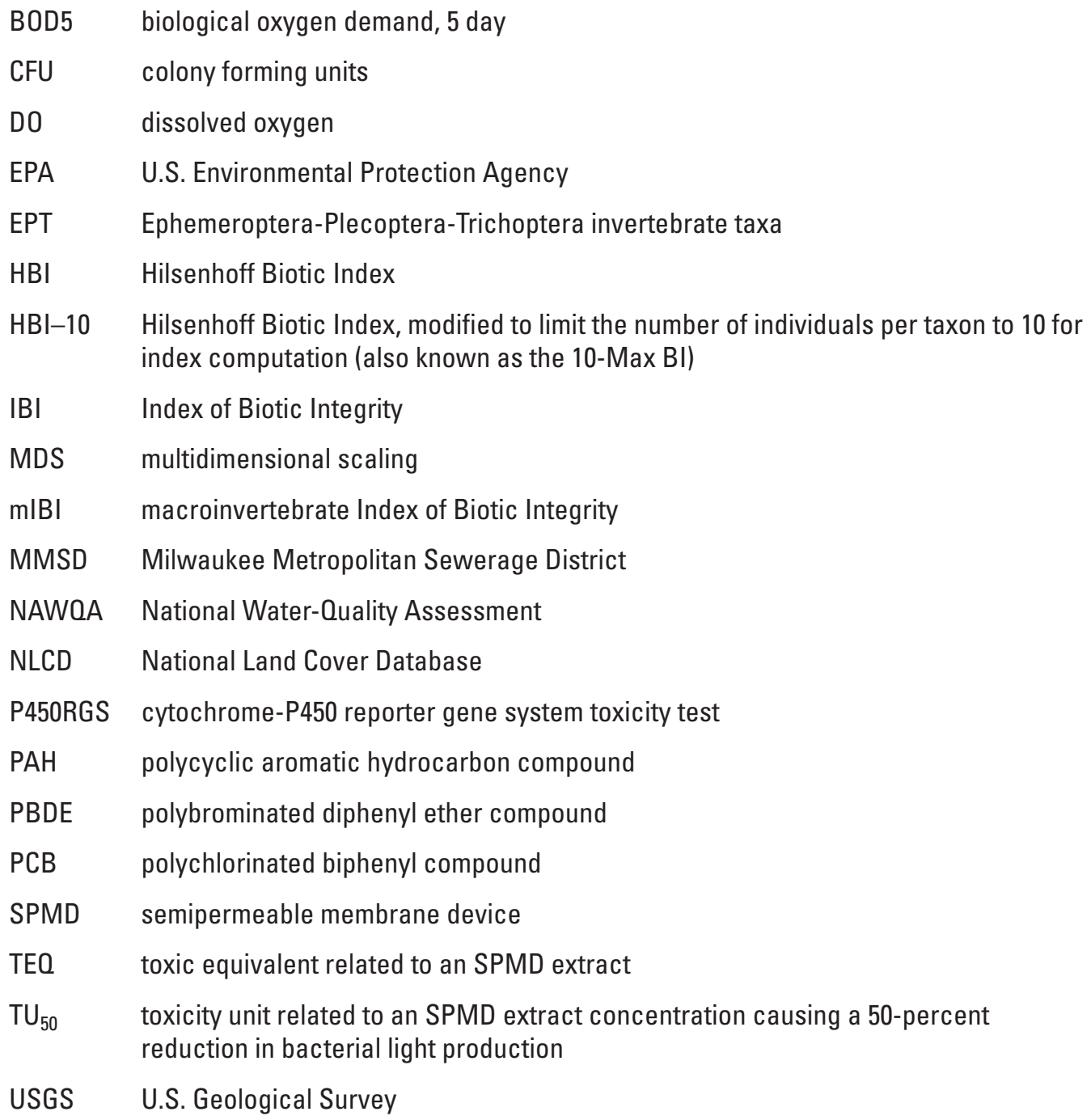

USGS U.S. Geological Survey 


\title{
Ecological Status of Aquatic Communities in Selected Streams in the Milwaukee Metropolitan Sewerage District Planning Area of Wisconsin, 2004-13
}

\author{
By Barbara C. Scudder Eikenberry, Michelle A. Nott, Jana S. Stewart, Daniel J. Sullivan, David A. Alvarez, \\ Amanda H. Bell, and Faith A. Fitzpatrick
}

\section{Abstract}

A total of 14 wadable streams in urban or urbanizing watersheds near Milwaukee, Wisconsin, were sampled in 2004, 2007, 2010, and 2013 to assess the ecological status of aquatic communities (biota), including benthic algae and invertebrates, and fish. To assess temporal variation, additional community sampling was also done at a subset of three sites in 2011 and 2012. Relative abundances of each type of organism were used to calculate biological metrics, such as richness and diversity, percentages of intolerant and tolerant organisms, and indexes of biotic integrity for invertebrates and fish. Selected environmental (physical and chemical) data in the streams were collected to evaluate potential relations to the biota and the ecological health of the stream. Physical and chemical data included land use/land cover, stream discharge from U.S. Geological Survey (USGS) streamgages (except at 2 creeks that were not gaged), stream habitat, microhabitat at invertebrate collection locations, water quality (except at 2 creeks that were not gaged), field measurements of several water-quality constituents, measures of benthic algal biomass, and toxicity and chemical tests on extracts from passive samplers deployed at a subset of 6 sites. Relative abundances of organisms and biological metrics were compared among sampling years and with environmental metrics to evaluate the ecological status of these streams and determine primary stressors on the aquatic communities, with the aim of helping resource managers understand and work toward improving the ecological health of these and other urban and urbanizing rivers in the study area.

Biological metrics for most sites indicated some level of diminished ecological status when compared across all sampled sites and when compared with rating scales for selected metrics. The least degraded sites among all those sampledindicated by aggregate bioassessments for algae, invertebrates, and fish metrics and in order starting with the best overall condition-were the Milwaukee River near Cedarburg, Menomonee River at Menomonee Falls, Jewel Creek, and Milwaukee River at Milwaukee. The most degraded sites were
Menomonee River at Wauwatosa, Root River at Greenfield, Lincoln Creek, and the Kinnickinnic River. Differences in aggregate bioassessments indicate that aquatic communities at the Menomonee River at Wauwatosa site and the Root River at Greenfield site were worse in 2013 than in 2004; however, Oak Creek and Honey Creek sites were better. In 2013, several sites had less than 30-percent pollution-sensitive diatoms indicating degraded algal assemblages. Invertebrate metrics for most of the 14 sites in 2013 were lower than in 2004 and indicate that invertebrate assemblages at most sampled sites were more degraded in 2013. Tolerant fish taxa made up more than 40 percent of assemblages at most sites and nearly 100 percent of assemblages at four sites. At times, in some smaller streams, too few fish were captured to compute an Index of Biotic Integrity with confidence, and invertebrates provided a better means for assessing the ecological status and water quality. With these few exceptions, the use of all three groups of biota provided the most robust assessments at the 14 sites in 2004-13.

Physical and chemical stressors were correlated to adverse effects on aquatic biota at the sampled streams. Passive samplers were deployed at a subset of six sites in 2013. Microtox results indicated there was little or no toxicity at the Milwaukee River near Cedarburg site and at the Oak Creek site, slight toxicity at the Lincoln Creek and Honey Creek sites, and moderate toxicity at the Milwaukee River at Milwaukee site and the Little Menomonee River site; however, based on cytochrome-P450 reporter gene system toxicity tests, potential toxicity from hydrophobic organic contaminants was measured at all six sites. For all 14 sites, physical and chemical stressors related to urbanization correlated with biological metrics for algae, invertebrates, and fish. Most stressors for aquatic biota reflected an urban signature. Stressors related to ecological condition in our study were chemical and physical, such as developed land, impervious surface in the watershed, urban land in a buffer area around the stream (a 100-foot [30-meter]-wide area on each side of the stream, and maximum instantaneous discharge normalized by drainage area (a measure of flood and scour effects). Chemical stressors included low waterborne concentrations of dissolved 
oxygen and high concentrations of chloride, zinc and other metals, nutrients (nitrite and phosphorus), and fecal coliform bacteria.

Although algae, invertebrates, and fish did not always demonstrate a significant response to the same stressors, higher abundances of high total phosphorus-indicator diatoms, lower ratings for invertebrate biotic integrity indexes and percentages of mayflies-stoneflies-caddisflies, and lower values for fish biotic integrity indexes underscored possible adverse effects of even low levels of developed land. Developed land is typically associated with more rapid runoff, which washes chemicals from impervious surfaces into area waterways and degrades stream habitat for aquatic communities. However, with respect to at least chloride from road salt, diatoms tolerant to dissolved salts were significantly lower with as little as 1-percent mixed forest in the watershed. Lower percentages of urban land in the stream buffer correlated with healthier aquatic assemblages of algae, invertebrates, and fish. The assessment of algal, invertebrate, and fish assemblages coupled with physical and chemical data were highly useful in evaluating the ecological status of aquatic communities at the 14 sites and for determining environmental stressors that may be contributing to reduced stream condition. Some of the stressors could potentially be removed or lessened with stream rehabilitation or changes in watershed management.

\section{Introduction}

With increasing urbanization in many areas of the United States and elsewhere, the resulting changes in stream discharge, water quality, and habitat can degrade streams and resident aquatic biota including algae, invertebrates, and fish (Paul and Meyer, 2001; Walsh and others, 2005; U.S. Environmental Protection Agency, 1997, 2006; Southeastern Wisconsin Regional Planning Commission and others, 2007; Coles and others, 2009, 2012; Richards and others, 2010). Streams in different areas of the country may not respond in the same way to the same environmental stressors because of underlying differences in watershed size, land use/ land cover, agricultural practices, soil chemistry, and topography (Buck and others, 2004; Coles and others, 2012). For this reason, long-term (years or even decades long) monitoring of the biological, chemical, and physical characteristics of stream sites provides a means to assess the relative importance of different stressors on the aquatic communities of selected streams in relation to local climate, soils, and other key environmental settings.

Multiple lines of evidence provided by biological, chemical, and physical data are critical in developing an understanding of how different land uses can adversely affect aquatic communities and how such effects might be mitigated through watershed management actions. An evaluation of the environmental stressors affecting aquatic communities requires monitoring of constituents in sufficient detail and frequency to be able to relate differences in constituents to differences in the aquatic communities. As land surfaces become urbanized, they are covered by less pervious surfaces such as developed open spaces and are more affected by impervious surfaces such as rooftops and paved areas, including roads, driveways, and parking lots (Schueler, 1994). Contaminants accumulate on impervious surfaces. When large amounts of rain fall on these surfaces, there are few, if any, porous and natural vegetated surfaces available to allow rainfall to soak into the ground, and chemicals and debris are therefore rapidly washed into local waterbodies. Increased sediment carried into streams during storms can smother aquatic organisms and fish spawning areas (Waters, 1995); other stream areas can be scoured of fine sediment. Rapid runoff can also lead to flooding and sudden peaks in stream discharge (referred to as "flashiness") with powerful erosion effects on habitat in the stream channel and on resident aquatic biota (Coles and others, 2012). Even low percentages (10 percent or less) of impervious surface in a watershed can have substantial adverse effects on aquatic biota in local waterbodies (Schueler, 1994; Arnold and Gibbons, 1996; Richards and others, 2010).

Aquatic biota are good indicators of stream water quality and overall stream condition even though they may differ in their responses to various environmental stressors (Richards and others, 2010; Scudder Eikenberry and others, 2010; Coles and others, 2012). Benthic organisms - biota attached to rocks, woody snags, and other substrates on the bottom or sides of the stream - are often regarded as the best sentinels for changes in water and sediment quality because of their site fidelity and their proximity to any contaminated sediment that may be present. Benthic algae reproduce quickly, living from days to weeks, and can indicate short-term changes in their environment. Diatom algae are especially good indicators because they are ubiquitous in aquatic environments, most can be identified to species, and their tolerances to a broad range of environmental conditions have been well studied. Benthic invertebrates, such as clams, snails, and the larvae of many insects, are also good indicators of water quality because of their relatively longer lifespans of months to years in comparison to algae, their mostly stationary nature that makes them indicative of site-specific conditions, and species-specific tolerances to environmental conditions. In general, fish have a longer lifespan and are more mobile than invertebrates, so fish can be potentially indicative of stream condition integrated over multiple years within a larger area such as a watershed. For these reasons, 3 groups of aquatic biota (algae, invertebrates, and fish) were collected to facilitate a more complete and robust assessment of stream condition at 14 sites in southeastern Wisconsin.

\section{Purpose and Scope}

The purpose of this report is to summarize U.S. Geological Survey (USGS) assessments of the ecological status of aquatic communities in selected wadable streams 
in the Milwaukee Metropolitan Sewerage District (MMSD) planning area in Wisconsin and implications for water quality in the streams. The assessment also included evaluations of potential physical and chemical stressors on the aquatic communities. The scope of the report includes data collected in 2010-13 (referred to as "phase IV") with comparisons to data collected in 2007 (referred to as "phase III") and 2004 (referred to as "phase II") (Schneider and others, 2004; Thomas and others, 2007; Scudder Eikenberry and others, 2010).

Aquatic communities were assessed at 14 stream sites based on the biological assemblage data and on selected biological measures (metrics) computed from these data. The potential level of toxicity to aquatic biota from synthetic organic compounds is estimated for a subset of six sites where passive sampling devices (semipermeable membrane devices [SPMDs]) were deployed. In addition, an analysis of selected chemical concentrations in SPMDs was completed for a timeintegrated concentration of the bioavailable fraction of polycyclic aromatic hydrocarbon compounds (PAHs). SPMD results are compared with biological assemblage data at sampled sites. Water-quality data from MMSD, stream discharge and water-quality data from USGS streamgages, land-use/landcover data, stream habitat, and measurement of ancillary data $(\mathrm{pH}$, specific conductance, light attenuation, and invertebrate microhabitat characterization) during ecological sampling events were evaluated as potential environmental stressors to aquatic biota in the study streams.

\section{Study Areas}

All stream sites were within the MMSD planning area (fig. 1 and table 1). The mouth of the Milwaukee River receives water from the Milwaukee, Menomonee, and Kinnickinnic River watersheds in addition to water from Lake Michigan (by way of reverse flow). Oak Creek and Root River discharge directly into Lake Michigan south of the Milwaukee Harbor. Jewel Creek ultimately discharges into the Mississippi River by way of the Fox and Illinois Rivers. Aquatic biological communities were sampled at the same 14 sites during 2004-13.

The site at the Milwaukee River near Cedarburg, Wis. (USGS station 04086600; hereafter referred to as the "Milwaukee River near Cedarburg site" or MRC), has probably the least visible disturbance of all sampled streams, and its biological communities support this observation. The lightly stained waters of this stream flow over a substrate of cobble and boulder with diverse habitats and, having generally good water quality, provide suitable habitat for a large number and variety of species of biota. This watershed drains about 607 square miles $\left(\mathrm{mi}^{2}\right)$ of mostly agriculture land (56 percent) and some urban land (12 percent), including two moderatesized cities; agricultural land decreased by about 1 percent since 2004 as development increased. Cedar Creek is a major tributary to the Milwaukee River and has a confluence 1.25 miles (mi) upstream from the sampling site.

At the Lincoln Creek at 47th Street at Milwaukee, Wis., site (USGS station 040869415; hereafter referred to as the "Lincoln Creek site" or LCM), a major stream-restoration project was completed in 2002 and encompassed the sampling reach. Before the 2004 sampling, the USGS completed sampling using the same methods used in 1993-5 (Peters and others, 1998). The restoration project included restructuring the channel and removing and replacing the streambed; all riparian vegetation was removed to allow for the major channel restructuring and streambank replacement. Canopy cover was minimal, even in 2013 in the sampling reach. These substantial modifications to the aquatic habitat contributed to ecological changes at this site independent of direct waterquality changes, and biota continue to adapt to the changed habitat. This is a small and highly urban stream, of which 94 percent is total urban, most of which is low- and mediumintensity developed land. Urban land makes up 65 percent of the stream buffer (a 100-foot [ft; 30-meter]-wide area on each side of the stream), one of the three highest values for urban land together with Honey Creek and the Kinnickinnic River. This small stream has endured decades of use by industry with legacy chemical contamination and downstream effects as well (Wisconsin Department of Health Services, 2005; Epping Overholt, 2014). Lincoln Creek joins the Milwaukee River about 1 mi upstream from the Milwaukee River at Milwaukee, Wis., sampling site (USGS station 04087000; hereafter referred to as the "Milwaukee River at Milwaukee site" or MRM).

The Milwaukee River at Milwaukee site has the largest area of all the MMSD study watersheds, draining $696 \mathrm{mi}^{2}$. The sampling site is in Estabrook Park and immediately downstream from Estabrook Dam, removed in 2018, and a large forested area on both banks. The watershed integrates a large northern area of mixed agriculture (51 percent), forest (14 percent) and low-density urban land with parts of the greater Milwaukee metropolitan urban area for a total of 18-percent urban land. Despite the urban setting, the river at this site supports quite a diverse aquatic community, including freshwater mussels and salmon traveling upstream from Lake Michigan.

Willow Creek at Maple Road, near Germantown, Wis., (USGS station 040870195; hereafter referred to as the "Willow Creek site" or WCG) is a small watershed of about $6 \mathrm{mi}^{2}$ that drains a wooded wetland area in the northwest part of the MMSD planning area. Agricultural land, which makes up 46 percent of the watershed, is slowly being converted to urban land, as urban areas increased by about 1.5 percent between 2001 and 2011. Willow Creek is a sand/silt-bottomed stream with abundant woody snags but no riffles or rock cobbles. For this reason, woody snags and not riffle rocks were sampled for algal and invertebrate samples at this site only. Although algal and invertebrate assemblages on woody snags 


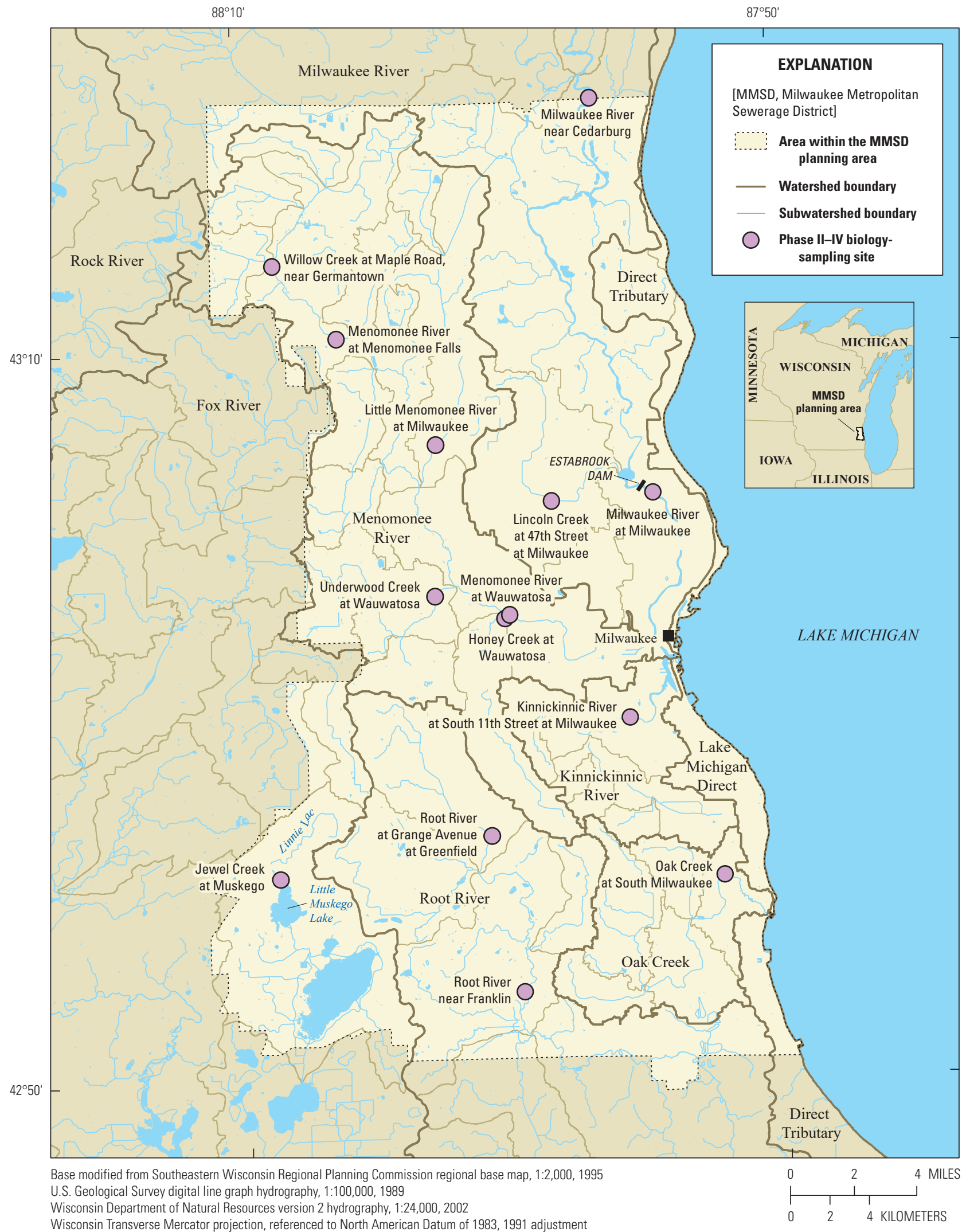

Figure 1. Sites where biological assessments were completed in 2004-13 in the Milwaukee Metropolitan Sewerage District planning area of Wisconsin. 
Table 1. U.S. Geological Survey stream sites where biological assessments were completed in 2004-13 in the Milwaukee Metropolitan Sewerage District planning area of Wisconsin, showing drainage area.

[Milwaukee Metropolitan Sewerage District water-quality site numbers are listed where water-quality data were obtained for ecological sampling years. USGS, U.S. Geological Survey; MMSD, Milwaukee Metropolitan Sewerage District; SPMD, semipermeable membrane device; mi², square mile; WI, Wisconsin; NC, not characterized; S., South]

\begin{tabular}{llcccc}
\hline $\begin{array}{c}\text { USGS station } \\
\text { number }\end{array}$ & \multicolumn{1}{c}{ Site name } & $\begin{array}{c}\text { Site } \\
\text { abbreviation }\end{array}$ & $\begin{array}{c}\text { MMSD water-quality } \\
\text { site number }\end{array}$ & $\begin{array}{c}\text { SPMDs deployed } \\
\text { (year) }\end{array}$ & $\begin{array}{c}\text { Drainage } \\
\text { area } \\
\text { (mi2) }\end{array}$ \\
\hline 04086600 & Milwaukee River near Cedarburg, WI & MRC & RI-01 & $2007,2010,2013$ & 607 \\
040869415 & Lincoln Creek at 47th Street at Milwaukee, WI & LCM & LC-04 & $2007,2010,2013$ & 9.56 \\
04087000 & Milwaukee River at Milwaukee, WI & MRM & RI-04 & 2010,2013 & 696 \\
040870195 & Willow Creek at Maple Road, near Germantown, WI & WCG & None & NC & 6.33 \\
04087030 & Menomonee River at Menomonee Falls, WI & MRMF & RI-16 & NC & 34.7 \\
04087070 & Little Menomonee River at Milwaukee, WI & LMM & ML-02 & NC & 19.7 \\
04087088 & Underwood Creek at Wauwatosa, WI & UCW & UC-07 & NC & 18.2 \\
04087119 & Honey Creek at Wauwatosa, WI & HCW & HC-03 & $2007,2010,2013$ & 10.3 \\
04087120 & Menomonee River at Wauwatosa, WI & MRW & RI-09 & NC & 123 \\
04087159 & Kinnickinnic River at S. 11th Street at Milwaukee, WI & KRM & RI-13 & 2007 & 18.8 \\
04087204 & Oak Creek at South Milwaukee, WI & OCSM & OC-05 & $2007,2010,2013$ & 25.0 \\
04087214 & Root River at Grange Avenue at Greenfield, WI & RRG & RR-04 & NC & 14.7 \\
04087220 & Root River near Franklin, WI & RRF & RR-05 & NC & 49.2 \\
05544371 & Jewel Creek at Muskego, WI & JCM & None & NC & 8.16 \\
\hline
\end{tabular}

will often be different from assemblages on rocks, this report focused more on identifying any long-term changes at this site than comparing this site with other sampled sites.

The Menomonee River at Menomonee Falls, Wis., site (USGS station 04087030; hereafter referred to as the "Menomonee River at Menomonee Falls site" or MRMF) drains about $35 \mathrm{mi}^{2}$ and is gradually changing from largely agricultural to more urban (41 and 36 percent, respectively) land use. The Menomonee River at Menomonee Falls is in a suburban setting in the middle of the city of Menomonee Falls. There is a narrow riparian zone of forest that provides partial shade adjacent to a public walkway and immediately upstream from a city road and city park. A series of riffles, runs, and pools on a natural substrate provides habitat for a variety of fish and invertebrates.

The Little Menomonee River at Milwaukee, Wis., site (USGS station 04087070; hereafter referred to as the "Little Menomonee River site" or LMM) is a mostly turbid and shaded reach in greenspace within an urban-industrial area and adjacent public access, which has resulted in a large amount of urban waste including shopping carts, tires, and so on being deposited in the stream channel. The watershed is relatively small at $20 \mathrm{mi}^{2}$ and is about 4 mi downstream from a Superfund site (Moss-American Superfund site) where remediation of creosote and PAHs was completed in 2010 (U.S. Environmental Protection Agency, 2010). The ecological sampling site is about $1.5 \mathrm{mi}$ upstream from the confluence with the Menomonee River. Just less than half (46 percent) of the watershed is urban, and 33 percent is agricultural. Tree canopy provides partial to complete shade of the stream reach. The only riffle in the reach is at the most upstream end of the reach, immediately downstream from a railroad bridge.

The Underwood Creek watershed is also small at about $18 \mathrm{mi}^{2}$ and is 90-percent urban, although most of the urban land is developed low-intensity land and developed open land (parks). The Underwood Creek at Wauwatosa, Wis., site (USGS station 04087088; hereafter referred to as the "Underwood Creek site" or UCW) is mostly concrete-lined channel with natural substrate at the most downstream end of the reach, about $0.1 \mathrm{mi}$ upstream from its confluence with the Menomonee River and adjacent to the Hansen Golf Course. Frequent and powerful high flows created an ever-enlarging scour pool immediately downstream from the concrete boundary and off the right bank. Invertebrate and algal samples were collected mostly in the concrete part but also in the cobble riffle adjacent to the large pool. In 2011, a large stormwater detention pond was completed immediately upstream between Underwood Creek Parkway and Swan Boulevard to help mitigate water and sediment from large rainfall-runoff events, and removal of the concrete in this reach began in November 2016 (Daniel, 2017) and was completed in August 2018 (Marty Melchior, Interfluve, Inc., written commun., February 7, 2019). For Underwood Creek in 2004 only, the data used were those collected about 3 mi upstream on the creek at Underwood Creek at Watertown Plank Road at Elm Grove, Wis. (USGS station 040870856), as part of the USGS National 
Ecological Status of Aquatic Communities in Selected Streams in the MMSD Planning Area of Wisconsin, 2004-13

Water-Quality Assessment (NAWQA) Program using the same methods as the current study. In 2007, data collection was moved to the present site adjacent to the Hansen Golf Course.

The Honey Creek at Wauwatosa, Wis., site (USGS station 04087119; hereafter referred to as the "Honey Creek site" or $\mathrm{HCW}$ ) is near the confluence with the Menomonee River and about 0.5 mi upstream from the Menomonee River at Wauwatosa site. A small watershed (about $10 \mathrm{mi}^{2}$ ), it is nearly 100-percent urban and mostly low and medium-intensity urban land. The reach is in a suburban area along a parkway, having only a narrow riparian area (vegetated area along the streambank) and a high value of 72-percent urban land in the stream buffer. The effects of high-powered storm runoff are evident in eroding and collapsing streambanks and associated fallen trees with log jams; nevertheless, multiple riffles and generally shallow depths over natural substrate provide good habitat for invertebrates and fish.

The Menomonee River at Wauwatosa, Wis., site (USGS station 04087120; hereafter referred to as the "Menomonee River at Wauwatosa site" or MRW) is near the confluence of Honey Creek and about 2 mi downstream from its confluence with Underwood Creek. The watershed is moderate in size at $123 \mathrm{mi}^{2}$ and is composed of 19-percent agricultural land and 65-percent urban land, with a relatively high percentage of urban land in the stream buffer (24 percent). The site was moved in 2007 from between 68th and 70th Streets to immediately upstream from 70th Street because of problems with access and wading after the original reach was restored in 2006. Abundant riffles were available for algal and invertebrate sampling at this site. Stream-restoration efforts completed in 2016 removed the final remaining fish barriers in this river to allow fish to migrate from Lake Michigan upstream to Menomonee Falls.

The Kinnickinnic River, a small watershed with a drainage area of about $19 \mathrm{mi}^{2}$, is nearly 100-percent urban land and more than 50-percent mean impervious surface. Although most of the urban land is low and medium intensity, this watershed has more high-intensity urban land than any of the other watersheds sampled (17 percent in 2013). This site has 74-percent urban land in the stream buffer, the highest for all sites. The Kinnickinnic River at South 11th Street at Milwaukee, Wis., site (USGS station 04087159; hereafter referred to as the "Kinnickinnic River site" or KRM) is a generally straight concrete channel with shallow flow most of the time. Extreme high flows during some rain events transport sediment and debris that scour the concrete channel and likely harm or remove aquatic organisms. Algal and invertebrate samples were collected at concrete seams and immediately upstream from the weir at the streamgage, where small bits of concrete and debris accumulate; these small areas were potentially the richest habitat in the reach. MMSD plans call for the concrete to be removed and a more natural channel constructed (Milwaukee Metropolitan Sewerage District, 2020).

The Oak Creek at South Milwaukee, Wis., site (USGS station 04087204; hereafter referred to as the "Oak Creek site" or OCSM) has a small watershed with a drainage area of about $25 \mathrm{mi}^{2}$ and mostly urban land use, which increased from 62 percent in 2001 to 68 percent in 2011 and was accompanied by a decrease in agricultural land and an increase in mean impervious surface from 26 to 29 percent. Oak Creek drains directly into Lake Michigan about $3 \mathrm{mi}$ downstream from the sampling site. General Mitchell International Airport is in the headwaters of the watershed. The streambed is mostly cobble and gravel with areas of sand. The main riffle was immediately upstream from the bridge on 15th Avenue, and a smaller riffle was present, at times, in the upstream part of the reach.

The Root River is mostly urban in the headwaters, with 93-percent urban land at the Root River at Grange Avenue at Greenfield, Wis., site (USGS station 04087214; hereafter referred to as the "Root River at Greenfield site" or RRG), and then the watershed transitions to more agricultural in the lower watershed with only 40-percent urban land overall at the Root River near Franklin, Wis., site (USGS station 04087220; hereafter referred to as the "Root River near Franklin site" or RRF); however, the area by the Root River near Franklin site is rapidly urbanizing. The stream is also small at Greenfield $\left(14.7 \mathrm{mi}^{2}\right)$ and medium in size near Franklin (about $49 \mathrm{mi}^{2}$ ). In most years, the only riffle for sampling at Greenfield was immediately downstream from the bridge at Grange Avenue, in part because of low water levels during sampling but also because of a general lack of cobble in the rest of the reach. Large cobble riffles with freshwater mussel beds were sampled near the USGS streamgage at the Root River near Franklin site.

Jewel Creek, at about $8 \mathrm{mi}^{2}$, is similar in size to Willow Creek and lies between two small lakes. Linnie Lac is a small lake about $0.1 \mathrm{mi}$ upstream from the Jewel Creek at Muskego, Wis., site (USGS station 05544371; hereafter referred to as the "Jewel Creek site" or JCM); Jewel Creek then flows into Little Muskego Lake less than $0.5 \mathrm{mi}$ downstream from the sampling site. About 40 percent of the watershed is urban, mostly low-intensity urban and developed open space, and 25 percent of the watershed is agricultural; nevertheless, mean impervious surface was 13 percent in 2013 and, therefore, above the 10-percent threshold where adverse effects might be observed on aquatic organisms (Richards and others, 2010). Streamrestoration work before the start of sampling in 2004 resulted in much of the substrate being composed of large rip rap and cobble rock riffles present only at the bottom and top of the reach where algae and invertebrates were collected.

\section{Methods}

Biological samples were collected once in 2004, 2007, 2010 , and 2013, generally during periods of stable low flow when problems with wading were minimized. However, beginning July 15,2010 , heavy rains inundated the area and peaked on July 22, 2010, when the Milwaukee area received about 7 inches of rain in just a few hours (National Weather Service, 2010). Widespread flooding of historic proportions 
occurred, and one of the hardest hit areas was along Lincoln Creek. All ecological sampling in 2010 was postponed for 4-5 weeks to allow streams to return to stable flows and to provide some time for algal, invertebrate, and fish assemblages to recover. To provide a measure of seasonal and temporal variability, algal and invertebrate assemblages were sampled in spring and fall (late May-June and late August-September) in 2011, 2012, and 2013. This information was essential for assessing the importance of long-term changes in aquatic communities at individual sites and ultimately for a more complete assessment of differences among sites.

\section{Data Collection}

Algal, invertebrate, and fish assemblage samples were collected in a defined stream reach (492-1,190 ft in length, depending on mean stream width) according to standard USGS methods documented in Moulton and others (2002) and Scudder Eikenberry and others (2010). Algal and invertebrate samples were collected concurrently during late August or September in each sampling year in the same general area of each reach (riffles), and fish were collected July through October in each sampling year. Riffles were chosen for algae and invertebrates because they are readily identifiable, tend to be more uniform than other stream habitats, have generally the highest oxygen concentration, and are shallow and wadable (Karr and Chu, 1999).

Algal-assemblage samples were collected from a known area on cobble in riffle areas, except for Willow Creek samples, which were collected from woody snags because riffle rocks were not available in this sand and silt substrate stream. At each site, 5 discrete collections from riffle rocks (or 2 discrete collections for snags) were made at each of 5 locations and combined into a single composited algal sample to represent that site. An aliquot of the algal composite sample was removed for analysis of chlorophyll $a$ (Arar and Collins, 1997) and ash-free dry mass (Britton and Greeson, 1987) at the USGS National Water Quality Laboratory in Denver, Colorado. Samples for identification were preserved to 5 percent (volume per volume) with formalin buffered to a $\mathrm{pH}$ of 7. The Academy of Natural Sciences in Philadelphia, Pennsylvania, identified and counted algae at the lowest practical taxonomic level (generally species or genus) and determined algal biovolume in all samples.

Except for 1 site, the Willow Creek, invertebrate assemblages were collected from 5 discrete cobble riffles in each reach using a modified Surber sampler with a 500-micronmesh net. All five subsamples were then combined into a single composite sample for each site (Moulton and others, 2002). At Willow Creek, where cobble riffles were unavailable, 10 discrete invertebrate collections were made from woody snags and combined into a single composite sample. Samples were preserved with 10-percent formalin buffered to a $\mathrm{pH}$ of 7; samples were later transferred to 70-percent ethanol before analysis by the laboratory. Identification and enumeration of invertebrates (generally species or genus) for all samples were done by the Aquatic Biomonitoring Laboratory at the University of Wisconsin-Stevens Point (Stevens Point, Wis.).

Representative fish assemblage sampling was completed at each site using backpack-mounted or towed-barge electrofishing units, depending on stream size or width, and seines (Moulton and others, 2002). A total of 2 electrofishing passes of the sampling reach were supplemented with 3 seine hauls per site. Fish were identified to the lowest practical taxonomic level (generally species), counted, noted for any anomalies, and then released live back to the stream. Rarely, when a fish could not be identified with certainty in the field, a few representative individuals were preserved for laboratory identification.

Stream habitat for the reach was assessed once in each sampling year, generally in late summer or early fall, except for 2007 when instream reach data were not collected because of funding constraints. Each habitat assessment included data collection at the reach, transect, and transect point levels. Reaches were established at each site using guidance from standard protocols used by the USGS NAWQA Program (Fitzpatrick and others, 1998) and ranged in length from 492 to $1,190 \mathrm{ft}$. Each reach was divided into 11 transects, along which more detailed data describing the physical stream channel were collected. Core data were collected across all years in accordance with the USGS NAWQA protocol. Beginning in 2010, additional measurements were added to these core habitat measurements to better quantify the physical conditions of each stream (Young and others, 2015).

Mean concentrations for selected water-quality constituents in whole (unfiltered) water samples were provided by MMSD for each year of biological sampling (Beth Sauer, MMSD, written commun., July 15, 2015); data were collected by MMSD at or near the ecological sampling sites except for the Lincoln Creek site, which was sampled by USGS in 2004-10 (no data for 2013), and for the Willow Creek and Jewel Creek sites in all years. Water samples collected by MMSD were discrete samples from the middle of the stream channel or where most of the discharge was occurring and, depending on conditions, from one depth (middepth) or two depths ( $1 \mathrm{~m}$ below the water surface and $1 \mathrm{~m}$ above the stream bottom; Milwaukee Metropolitan Sewerage District, 2013).

Discharge data were collected according to standard USGS methods (Rantz and others, 1982) at USGS streamgages near each of the ecological sampling sites, except for the Willow Creek and Jewel Creek sites where there were no nearby USGS streamgages. Water depth and velocity were recorded at each invertebrate microhabitat on the day of invertebrate sample collections. Light extinction coefficients, a measure of light penetration to the stream bottom, were obtained on the day of sampling and before other sampling components using a LI-COR light meter (Moulton and others, 2002). Surface-water field measurements, including water 
temperature, $\mathrm{pH}$, and specific conductance (conductivity), were collected concurrently with ecological sampling using a multiparameter sonde.

To quantify potential toxicity from hydrophobic organic chemicals (PAHs, polychlorinated biphenyls [PCBs], dioxins and furans, chlorinated pesticides, and polybrominated diphenyl ether compounds [PBDEs]), passive samplers (SPMDs) were deployed in duplicate for about 1 month at a subset of the 14 sites as described in Scudder Eikenberry and others (2010). The following sites were sampled in 2010 and 2013: Milwaukee River near Cedarburg, Milwaukee River at Milwaukee, Lincoln Creek, Little Menomonee River, Honey Creek, and Oak Creek at South Milwaukee, Wis. (USGS station 04087204; hereafter referred to as the "Oak Creek site"). In 2007, the Kinnickinnic River site and not the Milwaukee River at Milwaukee site was included in the sampling. The Milwaukee River at Milwaukee site was added beginning in 2010, before the planned sediment remediation of an area of PCB contamination about 1 mi upstream at Lincoln Park at the confluence of Lincoln Creek with the Milwaukee River (Lincoln Creek and the west oxbow of the Milwaukee River). The SPMDs deployed were 15.2-centimeter mini-SPMDs with ultrahigh-pure triolein inside protective metal containers, purchased from Environmental Sampling Technologies (EST Labs; St. Joseph, Missouri). One additional SPMD per site served as a "field blank" or field quality-assurance sample and was never deployed into the stream. To measure possible airborne contamination during deployment and retrieval, the cannister for each field blank was opened when the sample SPMD cannister was opened for deployment, and it was closed when the sample SPMD was placed in the water (total time less than 1 minute). For retrieval, the field blank cannister was opened when the sample SPMD was brought out of the water into air, and it was closed when the sample SPMD cannister was closed with the sample SPMD inside. The field blank data were used to determine the validity of any observed toxic response in the deployed SPMDs. After deployment, chemicals in the SPMDs were extracted for toxicity tests and PAH screening. One set of extracts was sent to the USGS Columbia Environmental Research Center (Columbia, Mo.) for Microtox toxicity tests and fluorescence test PAH screening. The Microtox test screens the extracts for acute toxicity from synthetic organic chemicals using strains of bioluminescent bacteria (Strategic Diagnostics, Inc., Newark, Delaware). When exposed to a toxicant, the rate of light production is reduced in proportion to the sample toxicity. The fluorescence screen for PAHs was completed by measuring the fluorescence of chemicals in the sample based on Johnson and others (2004). The PAH pyrene was targeted as a surrogate for all PAHs because pyrene is a commonly detected PAH in urban settings and is a good marker for determining PAH occurrence. A second set of extracts was sent to the U.S. Army Corps of Engineers, Engineer Research and Development Center-Waterways Experiment Station (Vicksburg, Mississippi) for cytochromeP450 reporter gene system (P450RGS) toxicity testing. The P450RGS test detects the presence of and potential biological response to PAHs, PCBs, dioxins and furans and was completed according to U.S. Environmental Protection Agency (EPA) Method 4425 using strains of bioluminescent hepatoma cells (Ang and others, 2000).

\section{Data Analysis}

Aquatic communities were evaluated by examining the number and kinds of organisms (taxa), number of individuals, pollution tolerance, and other traits. Many algal metrics have been developed by researchers over decades that are useful for characterizing water quality and stream condition based on environmental tolerances of algal taxa, especially diatoms (see summary by Porter [2008]). Algal metrics computed for the current study included the number of taxa ("richness"), the relative proportion of each algal group (including diatoms) out of all algal taxa, the percentage of eutrophic algae (diatoms and nondiatom or "soft" algae), and additional metrics specific to diatoms, including tolerances to nitrogen and phosphorus, dissolved oxygen (DO), chloride or salinity, and pollution in general (Lange-Bertalot, 1979; Bahls, 1993; Potapova and Charles, 2007; Porter, 2008). Diversity indexes quantify the number of taxa ("richness") present and the evenness in abundances across all species; that is, heterogeneity. For algae, Bahls (1993) diversity ratings for diatoms in low-gradient streams range from less than 1.5 ("high stress," low richness with highly uneven abundance), $1.50-2.50$ ("moderate stress"), and 2.51-3.50 ("minor stress") to greater than 3.50 ("no stress," high richness with mostly even abundance). "High stress" corresponds to few taxa and a low number ("abundance") of individuals except for one or two taxa that dominate; "no stress" corresponds to many taxa and a relatively even abundance across most or all taxa. Computed metrics for invertebrate samples included the number of invertebrate taxa; Shannon index of diversity (Shannon, 1948); the percentage of invertebrate individuals or genera in the orders Ephemeroptera-Plecoptera-Trichoptera (EPT); the percentage of invertebrates that are noninsects (leeches, oligochaetes, spiders and mites, nematodes, flatworms, springtails, amphipods, crayfish, isopods, and mollusks); scraper (algal grazer) invertebrates; the Hilsenhoff Biotic Index (HBI), the HBI modified to limit the number of individuals per taxon to 10 for index computation (HBI-10 hereafter, also known as the 10-Max BI; Hilsenhoff, 1987, 1998); and the macroinvertebrate Index of Biotic Integrity (mIBI) for Wisconsin (Weigel, 2003). EPT invertebrates generally are considered to be relatively intolerant of degraded water quality (Lenat, 1988); however, some species of mayflies and caddisflies are moderately tolerant. Intolerant (pollution-sensitive) organisms tend to dominate in streams with good water quality and habitat, whereas pollution-tolerant organisms dominate in streams with degraded water quality and habitat; therefore, the percentages of EPT individuals and of EPT genera tend to decrease as water quality degrades. Although the percentage of noninsects tends to increase with declines in water quality; 
native freshwater mussels, if present, contribute to the noninsect count even though they are considered to be indicative of good water quality. The HBI or HBI-10 is a multimetric (derived from multiple metrics) that relates water quality to the relative abundances of invertebrates that are tolerant or sensitive to environmental degradation. A modification of the HBI, the HBI-10, was used in the phase II and phase III analyses; the HBI-10 is thought to be more accurate than the HBI because it is less affected by the dominance of a single taxon (Hilsenhoff, 1998). HBI-10 scores can range from less than 3.5 ("excellent") to 10 ("very poor"), and therefore, lower HBI-10 scores indicate a better rating and higher scores indicate a worse rating. Values for the mIBI, a multimetric derived from 11 invertebrate metrics, also can range from 0.00 to 10.00 , but its ratings are opposite of those of the HBI or HBI-10 (Weigel, 2003). Assemblage information and metrics for invertebrate samples were provided by the Aquatic Biomonitoring Laboratory at the University of WisconsinStevens Point (Stevens Point, Wis.). Metrics computed for fish assemblages included the number of species and individuals, native fish species, predator fish, number of fish in certain groups such as sunfishes and suckers, pollution-sensitive and pollution-tolerant fish, and fish Index of Biotic Integrity (IBI) for Wisconsin warmwater streams (Lyons, 1992). The fish IBI is a multimetric derived from a series of 10 metrics and is standardized to 100 such that scores range from 60 or greater ("excellent") to 0 ("very poor").

A subset of six metrics consisting of some for each group of biota were selected to represent the status of each group (algae, percentage of most tolerant diatoms and percentage of sensitive diatoms; invertebrates, Shannon index of diversity scores, percentage of EPT taxa, and HBI-10 scores; fish, IBI score). Metrics were selected because of their known sensitivity to water quality and to provide the most complete assessment for each group using multimetrics where possible. These metrics were standardized (ranked, lowest rank indicating best water quality) and averaged for each biotic assemblage. The means of these ranks were then averaged across all assemblages to yield aggregate bioassessment rankings for each site. Sites were divided into four groups based on quartiles of these aggregate bioassessment rankings: (group 1) less than the 25th percentile; (group 2) equal to or greater than the 25th but less than the 50th percentiles; (group 3) equal to or greater than the 50th but less than the 75th percentiles; and (group 4) greater than or equal to the 75th percentile. Group 1 contained sites at which aggregate bioassessment rankings indicated the least degraded water quality among those sampled, and group 4 contained sites at which rankings indicated the most degraded water quality.

Physical data were evaluated by calculating representative values for ecological sampling site conditions, by site and year. Stream habitat metric calculations were largely consistent in content and approach with the metrics outlined in Richards and others (2010); the only metric omitted here was the streambed substrate index (BedSubIndex) because it seemed to be of little use compared with the other metrics.
In augmentation to Richards and others (2010), all bankfull metrics were calculated with and without pool transects (this included calculating the metrics with pools [bankfull width divided by drainage area and bankfull depth divided by drainage area] and the metrics without pools [bankfull shear stress and critical particle size for insipient motion]). Additionally, all habitat metrics present for the sites in the USGS BioData database (available at https://aquatic.biodata.usgs.gov/ landing.action) were used. Additional metrics, including mean silt depth, velocity multiplied by wetted depth (related to discharge), coefficient of variation for bed substrate size, and a mixed graphical and arithmetic approach of mean bed substrate size (Trask, 1932; Bunte and Abt, 2001; the sum of the 25 th and 75 th quantiles divided by two), were included.

Stream discharge metrics (in cubic feet per second) were computed using data from USGS streamgages. Selected metrics were calculated for the years of ecological sampling, including discharge exceeded 10 percent of the time, discharge exceeded 50 percent of the time, maximum daily mean discharge, minimum daily mean discharge, and maximum instantaneous discharge, and were standardized by drainage area. In addition, mean discharge conditions on the day of sample collection were also calculated using data from USGS streamgages. Where available, unit values were used to calculate mean flows for the 4 hours after the sample start time, otherwise precalculated daily values were used. No discharge data were available for the Willow Creek and Jewel Creek sites but discharge data for the other sites listed in table 1 are available using the USGS station number from the USGS National Water Information System database (U.S. Geological Survey, 2016).

A geographic information system was used to summarize land cover and percentage of impervious statistics for each ecological sampling site using National Land Cover Database (NLCD) 2006 and 2011 datasets (U.S. Geological Survey, 2014). Data from the NLCD 2001 dataset were used to characterize conditions for the 2004 ecological samples, data from the NLCD 2006 dataset were used for the 2007 ecological samples, and data from the 2011 dataset were used to characterize conditions for ecological samples collected from 2010 to 2013. In summarizing land-cover statistics, total urban land was considered the sum of the developed landcover categories (codes 21-24) and total agricultural land was considered the sum of the agricultural land-cover categories (codes 81-82). The percentage of impervious statistics for each site were based on the NLCD Percent Imperviousness dataset, generated from the LANDSAT imagery (Xian and others, 2011). The NLCD data were converted to a grid file before analyzing for the percentage of impervious statistics by watershed. Additionally, land-cover statistics were determined for the stream buffer at each site by generating a 200 -ft-wide area ("60-meter stream buffer"), 100-ft (30-meter)-wide area on each side of the hydrographic lines, beginning at the most upstream point in the watershed and extending downstream to the bottom of the sampling reach, and summarizing data 
Ecological Status of Aquatic Communities in Selected Streams in the MMSD Planning Area of Wisconsin, 2004-13

from the NLCD 2011 dataset. Total urban land in the stream buffer was considered the sum of the low, medium, and highintensity urban land-cover categories (codes 22-24).

SPMD results for Microtox and P450RGS were standardized to 30 days to allow comparison across sites, and concentrations of chemicals determined in the PAH screen were standardized using the mean number of days deployed (37). Microtox results are reported in terms of EPA toxicity units $\left(\mathrm{TU}_{50} \mathrm{~s}\right)$, which are determined by dividing 100 by the effective concentration of the SPMD extract that caused a 50 -percent reduction in light production by the bacteria. For the Fluoroscan fluorescence screen, total PAH water concentrations were estimated using pyrene as a representative common PAH. Results are presented as the estimated timeweighted average water concentration for all constituents with available uptake kinetics (sampling rates) from the literature (Alvarez and others, 2008).

Statistical methods used in data analyses included basic descriptive statistics, such as means and quartiles, graphing, and Spearman's rank correlation coefficient or "rho" (Data Desk version 6.1; Data Description Inc., 1996). Microsoft Excel and SigmaPlot 11.0 were used for creating bar plots and scatterplots, respectively. Unless otherwise stated, use of the term "significant" refers to statistical values of probability $(p)$ less than $(<) 0.05$ in data comparisons. Multivariate statistical analyses to examine patterns in the relative abundances of taxa were done using routines in the PRIMER 6 software (Clarke and Gorley, 2006), including multidimensional scaling (MDS). MDS represents objects, such as samples, in plots of two or three dimensions where dissimilar objects plot far apart and similar objects plot close together. Before multivariate testing, taxa relative abundances were determined, and a Bray-Curtis similarity matrix was calculated from a fourth-root transformation of relative abundance data. A fourth-root transformation decreases the effects of common taxa and increases the effects of intermediate and rare taxa such that more taxa have an effect in the final multivariate analyses (Clarke and Warwick, 2001). The Bray-Curtis similarity matrices then formed the basis of MDS analyses.

\section{Assessment of Aquatic Communities in Relation to Stream Condition}

Algal, invertebrate, and fish assemblages provided valuable insight into the overall condition of the studied streams over the period of study by differences in the abundances of various taxa and by sensitivities to disturbance and pollution as measured through the computed biological metrics and correlations of metrics to environmental stressors. The following sections first provide a comparison across streams for each group of biota, followed by SPMD results at a subset of sites, relations to environmental stressors across all sites, and finally, individual stream summaries. Biological results for 2004 and
2007 are discussed in detail in Scudder Eikenberry and others (2010). All data generated during this study are available as a USGS data release (Scudder Eikenberry and others, 2020).

\section{Comparative Bioassessment across Sampled Streams}

Bioassessments at the 14 study streams revealed the importance of sampling multiple groups of aquatic organisms and computing multiple biological measures or metrics for each group. Some metrics proved more comprehensive for evaluating the ecological health of sites, and these included metrics composed of several metrics (multimetric indexes). The strength and utility of multimetric indexes have been well described by numerous researchers in the literature (Karr, 1981; Hilsenhoff, 1982; Lyons, 1992; Karr and Chu, 1999). Differences between years for a single metric could not be tested statistically because of the study design of one sample per year (or two per year in a few cases); therefore, references to one or more metrics being higher or lower at one or more sites are numerical and not statistical statements.

\section{Algae}

Algal assemblages varied in the abundance and distribution of taxa across years at sites, and the variation was greater at some sites than at others. This within-site variation is illustrated by an MDS plot where more similar assemblages are represented as points grouped closely together and less similar assemblages are represented as points more distant to each other (fig. 2). Notably, assemblages grouped on the right side of the plot for 2004 and 2007 and on the left side of the plot for later years. Upon closer examination on a site-by-site basis, fall algal assemblages were similar to each other in 2004 and 2007 but were greatly different in 2010. In 2013, algal assemblages returned to a structure more similar to 2007 and less so to 2004. For sites with additional sampling in spring and fall in 2011 to 2013, the assemblages in fall 2010 and spring and fall 2011 were more similar to each other than to other years. The assemblages in fall 2012 and 2013 were more similar to each other than to 2010 or 2011. Spring and fall assemblages for a single year generally grouped together at each temporal site; nevertheless, MDS results indicate a large part of the variability was because of differences in the assemblages in 2010 and 2011, possibly because of the extreme flooding during 2010 in many area streams. The general grouping by year evident in the algal MDS plot indicates that some of the variability in the algal assemblages can be explained by large-scale effects like weather that dominate the whole region, as opposed to site-specific factors.

The number of algal taxa collected at each site (richness) varied across years and was generally higher in 2013 than in 2004 (table 2). A total of 199 algal taxa were collected across all sites in 2013, compared with 177 taxa that were collected in 2004. The median number of taxa was higher in 2013 


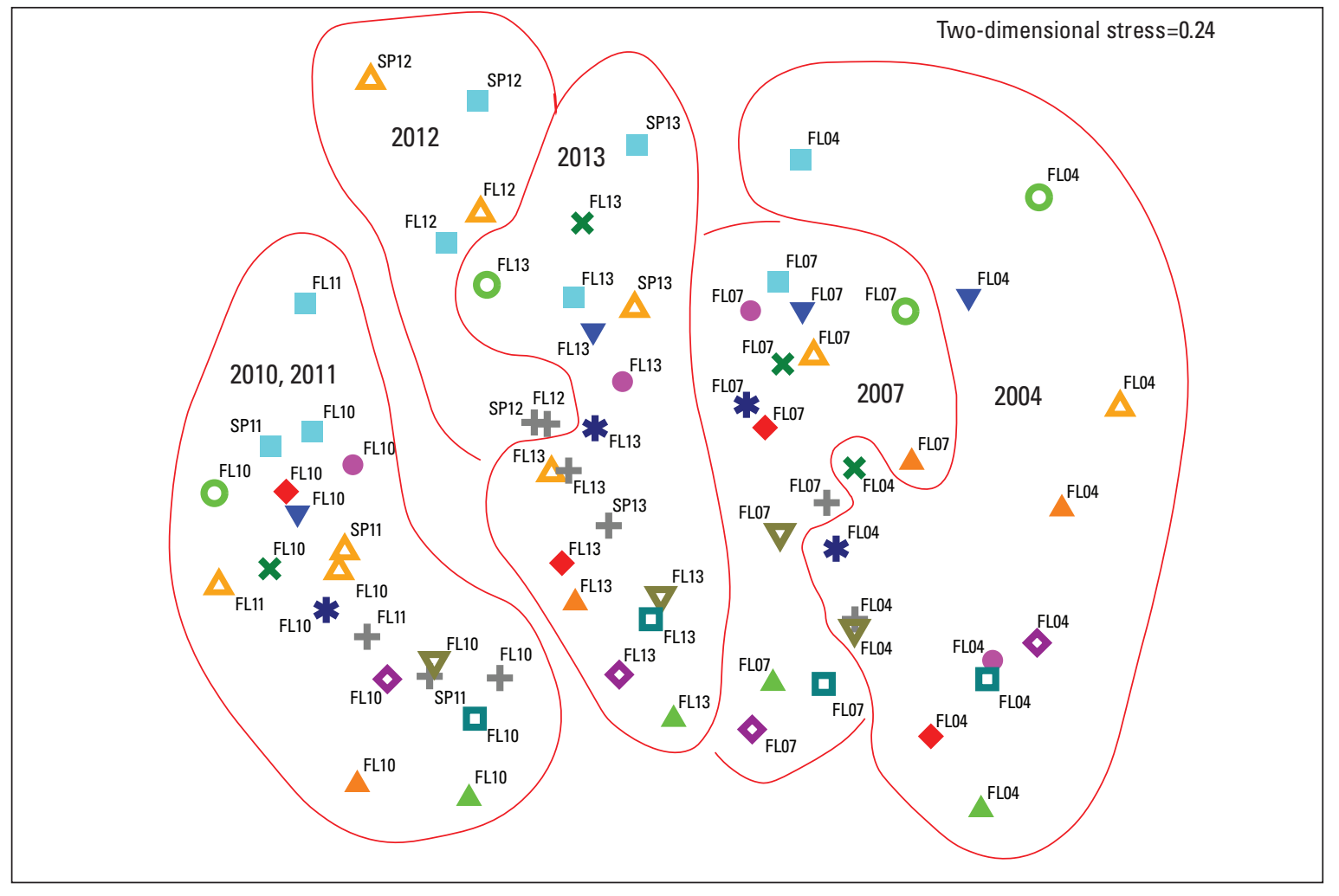

\section{EXPLANATION}

[MRC, Milwaukee River near Cedarburg; LCM, Lincoln Creek at 47th Street at Milwaukee; MRM, Milwaukee River at Milwaukee; WCG, Willow Creek at Maple Road, near Germantown; MRMF, Menomonee River at

Menomonee Falls: LMM, Little Menomonee River at

Milouke UCW, Underwood Creek at Wauwatos;

MCW

HCW, Honey Creek at Wautosa; River at Wauwatosa; KRM, Kinsickin River at South Milweet at Mauke, OCSM, Oak Creek at Sou

Milwakee, RRG, Root River at Grange Avenue at

Greenfield; RRF, Root River near Franklin; JCM, Jewel
Creek at Muskego; SP, spring samples; FL, fall samples

\section{Site abbreviation}
$\triangle$ MRC
- LCM
* MRM
$\triangle$ WCG
+ MRMF
$>$ LMM
U UCW
HCW
$\times$ MRW
$\nabla$ KRM
$\nabla$ OCSM
口 RRG
$\bullet$ RRF
$\triangle \mathrm{JCM}$

Figure 2. Multidimensional scaling ordination plot for algal assemblages collected at 14 sites in the Milwaukee area, Wisconsin, 2004-13. [The sampling year is shown as $04,07,10,11,12$, and 13 for 2004, 2007, 2010, 2011, 2012, and 2013] 
Table 2. Algal-assemblage information from surveys completed in 2004, 2007, 2010, and 2013 at 14 stream sites in the Milwaukee Metropolitan Sewerage District planning area, Wisconsin.

TThe percentage of nuisance algae is the sum of benthic and sestonic algal producers (Porter, 2008); the percentage of eutrophic diatoms is the sum of mesotrophic-eutrophic, eutrophic, polytrophic, and eurytrophic diatoms (van Dam and others, 1994); the percentage of relative abundance of diatoms is based on Bahls (1993). The percentage of difference in metric values between 2013 and 2004 is shown (Difference), and percentages greater than 10 percent are highlighted; yellow denotes a potentially adverse difference, and blue denotes a potentially beneficial difference; and gray denotes a difference of unknown effect; $\mu \mathrm{L}$, microliter; $\mathrm{cm}^{2}$, square centimeter; USGS, U.S. Geological Survey; --, no data or not applicable]

\begin{tabular}{|c|c|c|c|c|c|c|c|c|c|c|c|c|c|}
\hline \multirow[b]{2}{*}{$\begin{array}{l}\text { Sampling } \\
\text { year }\end{array}$} & \multirow[b]{2}{*}{$\begin{array}{l}\text { Number } \\
\text { of taxa }\end{array}$} & \multirow[b]{2}{*}{$\begin{array}{c}\text { Biovolume } \\
\left(\mu \mathrm{L} / \mathrm{cm}^{2} \times 10^{6}\right)\end{array}$} & \multirow[b]{2}{*}{$\begin{array}{c}\text { Cell density } \\
\text { (cells/cm²×106) }\end{array}$} & \multirow[b]{2}{*}{$\begin{array}{l}\text { Shannon } \\
\text { index of } \\
\text { diversity }\end{array}$} & \multirow[b]{2}{*}{$\begin{array}{l}\text { Nuisance } \\
\text { algae } \\
\text { (percent) }\end{array}$} & \multicolumn{8}{|c|}{ Percentage of relative abundance of diatoms } \\
\hline & & & & & & Eutrophic & $\begin{array}{c}\text { Pollution } \\
\text { tolerant }\end{array}$ & $\begin{array}{l}\text { Pollution } \\
\text { moderate }\end{array}$ & $\begin{array}{l}\text { Pollution } \\
\text { sensitive }\end{array}$ & $\begin{array}{l}\text { Pollution } \\
\text { tolerance } \\
\text { unknown }\end{array}$ & $\begin{array}{c}\text { Halobiontic } \\
\text { diatoms }\end{array}$ & $\begin{array}{c}\text { Fresh- } \\
\text { brackish } \\
\text { water } \\
\text { diatoms }\end{array}$ & $\begin{array}{c}\text { Freshwater } \\
\text { diatoms }\end{array}$ \\
\hline \multicolumn{14}{|c|}{ Milwaukee River near Cedarburg (USGS station 04086600) } \\
\hline 2004 & 48 & 5,251 & 3.1 & 0.93 & 0.14 & 77.5 & 1.33 & 16.5 & 63.2 & 19.0 & 22.5 & 56.2 & 0.67 \\
\hline 2007 & 50 & 29,944 & 81 & 1.75 & 0.041 & 93.0 & 23.3 & 37.3 & 32.3 & 7.01 & 28.0 & 64.8 & 0.91 \\
\hline 2010 & 63 & 8,582 & 9.4 & 1.80 & 0.21 & 89.8 & 13.2 & 43.8 & 36.3 & 6.67 & 25.5 & 67.0 & 0.33 \\
\hline 2013 & 55 & 97,276 & 4.0 & 2.10 & 1.1 & 92.5 & 11.0 & 31.8 & 53.7 & 3.50 & 16.0 & 80.0 & 0.17 \\
\hline Difference & 15 & 1,752 & 26 & 130 & 1.0 & 15.0 & 9.67 & 15.3 & -9.50 & -15.5 & -6.50 & 23.8 & -0.50 \\
\hline \multicolumn{14}{|c|}{ Lincoln Creek at 47th Street at Milwaukee (USGS station 040869415) } \\
\hline 2004 & 37 & 28,893 & 16 & 0.74 & 0 & 90.6 & 8.87 & 71.1 & 12.6 & 7.39 & 66.7 & 24.5 & 2.3 \\
\hline 2007 & 40 & 53,118 & 16 & 1.59 & 1.2 & 92.3 & 27.7 & 46.0 & 19.5 & 6.87 & 42.1 & 51.2 & 0.0 \\
\hline 2010 & 39 & 1,503 & 8.2 & 1.74 & 0 & 89.2 & 25.5 & 50.5 & 14.3 & 9.67 & 48.2 & 42.5 & 0.17 \\
\hline 2013 & 55 & 13,155 & 17 & 2.11 & 0 & 94.3 & 26.8 & 44.5 & 25.2 & 3.50 & 40.3 & 55.8 & 0.17 \\
\hline Difference & 49 & -54.5 & 6.9 & 184 & 0.0 & 3.69 & 18.0 & -26.6 & 12.5 & -3.89 & -26.3 & 31.4 & -2.1 \\
\hline \multicolumn{14}{|c|}{ Milwaukee River at Milwaukee (USGS station 04087000) } \\
\hline 2004 & 70 & 166,650 & 5.4 & 1.47 & 0 & 88.7 & 5.75 & 38.1 & 44.7 & 11.5 & 17.9 & 72.2 & 0.16 \\
\hline 2007 & 57 & 2,608 & 6.9 & 2.01 & 0.65 & 92.4 & 11.7 & 46.1 & 35.7 & 6.49 & 34.7 & 59.4 & 1.6 \\
\hline 2010 & 72 & 1,140 & 5.3 & 1.93 & 0 & 75.0 & 14.2 & 38.7 & 34.3 & 12.8 & 25.2 & 52.5 & 2.0 \\
\hline 2013 & 61 & 607.2 & 3.5 & 1.60 & 0 & 89.8 & 16.0 & 43.5 & 35.0 & 5.50 & 15.2 & 78.0 & 0.33 \\
\hline Difference & -13 & -99.6 & -36 & 8.34 & 0.0 & 1.16 & 10.0 & 5.40 & -9.66 & -5.99 & -2.73 & 5.75 & 0.17 \\
\hline
\end{tabular}


Table 2. Algal-assemblage information from surveys completed in 2004, 2007, 2010, and 2013 at 14 stream sites in the Milwaukee Metropolitan Sewerage District planning area, Wisconsin.-Continued

[The percentage of nuisance algae is the sum of benthic and sestonic algal producers (Porter, 2008); the percentage of eutrophic diatoms is the sum of mesotrophic-eutrophic, eutrophic, polytrophic, and eurytrophic diatoms (van Dam and others, 1994); the percentage of relative abundance of diatoms is based on Bahls (1993). The percentage of difference in metric values between 2013 and 2004 is shown (Difference), and percentages greater than 10 percent are highlighted; yellow denotes a potentially adverse difference, and blue denotes a potentially beneficial difference; and gray denotes a difference of unknown effect; $\mu \mathrm{L}$, microliter; $\mathrm{cm}^{2}$, square centimeter; USGS, U.S. Geological Survey; --, no data or not applicable]

\begin{tabular}{|c|c|c|c|c|c|c|c|c|c|c|c|c|c|}
\hline \multirow[b]{2}{*}{$\begin{array}{l}\text { Sampling } \\
\text { year }\end{array}$} & \multirow[b]{2}{*}{$\begin{array}{c}\text { Number } \\
\text { of taxa }\end{array}$} & \multirow[b]{2}{*}{$\begin{array}{c}\text { Biovolume } \\
\left(\mu \mathrm{L} / \mathrm{cm}^{2} \times 10^{6}\right)\end{array}$} & \multirow[b]{2}{*}{$\begin{array}{c}\text { Cell density } \\
\text { (cells/cm²×106) }\end{array}$} & \multirow[b]{2}{*}{$\begin{array}{l}\text { Shannon } \\
\text { index of } \\
\text { diversity }\end{array}$} & \multirow[b]{2}{*}{$\begin{array}{l}\text { Nuisance } \\
\text { algae } \\
\text { (percent) }\end{array}$} & \multicolumn{8}{|c|}{ Percentage of relative abundance of diatoms } \\
\hline & & & & & & Eutrophic & $\begin{array}{l}\text { Pollution } \\
\text { tolerant }\end{array}$ & $\begin{array}{l}\text { Pollution } \\
\text { moderate }\end{array}$ & $\begin{array}{l}\text { Pollution } \\
\text { sensitive }\end{array}$ & $\begin{array}{l}\text { Pollution } \\
\text { tolerance } \\
\text { unknown }\end{array}$ & $\begin{array}{c}\text { Halobiontic } \\
\text { diatoms }\end{array}$ & $\begin{array}{c}\text { Fresh- } \\
\text { brackish } \\
\text { water } \\
\text { diatoms }\end{array}$ & $\begin{array}{c}\text { Freshwater } \\
\text { diatoms }\end{array}$ \\
\hline \multicolumn{14}{|c|}{ Willow Creek at Maple Road, near Germantown (USGS station 040870195) } \\
\hline 2004 & 45 & 251.9 & 0.44 & 2.42 & 0 & 73.8 & 13.2 & 13.8 & 65.2 & 7.83 & 7.2 & 67.0 & 2.2 \\
\hline 2007 & 43 & 4,170 & 1.5 & 2.00 & 0.39 & 94.2 & 16.1 & 35.4 & 42.5 & 5.93 & 22.6 & 71.5 & 0.49 \\
\hline 2010 & 50 & 181.6 & 1.2 & 2.22 & 0 & 85.8 & 5.67 & 37.0 & 36.8 & 20.5 & 11.5 & 75.0 & 1.0 \\
\hline 2013 & 44 & 56.4 & 0.37 & 2.31 & 0 & 95.0 & 14.2 & 26.2 & 37.8 & 21.8 & 13.8 & 83.0 & 0.0 \\
\hline Difference & -2.2 & -77.6 & -16 & -4.69 & 0.0 & 21.2 & 1.00 & 12.3 & -27.3 & 14.0 & 6.67 & 16.0 & -2.2 \\
\hline \multicolumn{14}{|c|}{ Menomonee River at Menomonee Falls (USGS station 04087030) } \\
\hline 2004 & 36 & 520.0 & 3.4 & 1.62 & 0 & 92.4 & 5.43 & 33.7 & 53.5 & 7.40 & 32.7 & 60.0 & 0.99 \\
\hline 2007 & 32 & 506.6 & 3.0 & 1.53 & 0 & 95.3 & 2.28 & 6.03 & 85.7 & 6.03 & 4.07 & 91.5 & 0.33 \\
\hline 2010 & 59 & 284.4 & 1.0 & 2.20 & 0 & 83.9 & 8.97 & 25.2 & 53.2 & 12.6 & 13.1 & 73.8 & 0.66 \\
\hline 2013 & 37 & 23,300 & 5.1 & 1.80 & 0.20 & 93.5 & 7.67 & 30.2 & 56.2 & 6.00 & 22.5 & 73.8 & 0.0 \\
\hline Difference & 2.8 & 4,381 & 51 & 11.3 & 0.20 & 1.07 & 2.24 & -3.55 & 2.71 & -1.40 & -10.2 & 13.8 & -0.99 \\
\hline \multicolumn{14}{|c|}{ Little Menomonee River at Milwaukee (USGS station 04087070) } \\
\hline 2004 & 31 & 409.6 & 4.7 & 1.66 & 0 & 92.6 & 5.72 & 53.3 & 33.3 & 7.68 & 49.0 & 44.0 & 0.49 \\
\hline 2007 & 30 & 3,307 & 16 & 2.04 & 0 & 96.2 & 26.2 & 31.4 & 39.0 & 3.35 & 30.2 & 66.3 & 0.30 \\
\hline 2010 & 45 & 836.4 & 12 & 2.11 & 0.43 & 89.2 & 11.2 & 65.3 & 15.0 & 8.50 & 55.0 & 35.0 & 0.50 \\
\hline 2013 & 41 & 910.8 & 10 & 2.25 & 0 & 94.7 & 11.0 & 27.2 & 58.5 & 3.33 & 20.0 & 75.7 & 0.83 \\
\hline Difference & 32 & 122.3 & 120 & 35.4 & 0.0 & 2.02 & 5.28 & -26.1 & 25.2 & -4.35 & -29.0 & 31.7 & 0.34 \\
\hline \multicolumn{14}{|c|}{ Underwood Creek at Wauwatosa (USGS station 04087088) } \\
\hline 2004 & 42 & 769.4 & 12 & 0.81 & 0.66 & 90.2 & 9.33 & 41.5 & 45.0 & 4.17 & 28.0 & 63.7 & 0.0 \\
\hline 2007 & 35 & 1,148 & 13 & 1.55 & 0 & 93.4 & 10.6 & 67.0 & 15.7 & 6.77 & 58.1 & 35.3 & 0.50 \\
\hline 2010 & 48 & 573.4 & 4.2 & 2.36 & 1.7 & 89.0 & 6.33 & 72.0 & 12.3 & 9.33 & 59.7 & 30.3 & 2.5 \\
\hline 2013 & 45 & 37,024 & 2.2 & 1.84 & 0.74 & 95.8 & 11.8 & 62.2 & 23.7 & 2.33 & 55.8 & 42.0 & 0.0 \\
\hline Difference & 7.1 & 4,712 & -81 & 129 & 0.09 & 5.67 & 2.50 & 20.7 & -21.3 & -1.83 & 27.8 & -21.7 & 0.0 \\
\hline
\end{tabular}


Table 2. Algal-assemblage information from surveys completed in 2004, 2007, 2010, and 2013 at 14 stream sites in the Milwaukee Metropolitan Sewerage District planning area,

Wisconsin.-Continued

[The percentage of nuisance algae is the sum of benthic and sestonic algal producers (Porter, 2008); the percentage of eutrophic diatoms is the sum of mesotrophic-eutrophic, eutrophic, polytrophic, and eurytrophic diatoms (van Dam and others, 1994); the percentage of relative abundance of diatoms is based on Bahls (1993). The percentage of difference in metric values between 2013 and 2004 is shown (Difference), and percentages greater than 10 percent are highlighted; yellow denotes a potentially adverse difference, and blue denotes a potentially beneficial difference; and gray denotes a difference of unknown effect; $\mu \mathrm{L}$, microliter; $\mathrm{cm}^{2}$, square centimeter; USGS, U.S. Geological Survey; --, no data or not applicable]

\begin{tabular}{|c|c|c|c|c|c|c|c|c|c|c|c|c|c|}
\hline \multirow[b]{2}{*}{$\begin{array}{l}\text { Sampling } \\
\text { year }\end{array}$} & \multirow[b]{2}{*}{$\begin{array}{c}\text { Number } \\
\text { of taxa }\end{array}$} & \multirow[b]{2}{*}{$\begin{array}{c}\text { Biovolume } \\
\left(\mu \mathrm{L} / \mathrm{cm}^{2} \times 10^{6}\right)\end{array}$} & \multirow[b]{2}{*}{$\begin{array}{c}\text { Cell density } \\
\text { (cells/cm²×106) }\end{array}$} & \multirow[b]{2}{*}{$\begin{array}{l}\text { Shannon } \\
\text { index of } \\
\text { diversity }\end{array}$} & \multirow[b]{2}{*}{$\begin{array}{c}\text { Nuisance } \\
\text { algae } \\
\text { (percent) }\end{array}$} & \multicolumn{8}{|c|}{ Percentage of relative abundance of diatoms } \\
\hline & & & & & & Eutrophic & $\begin{array}{c}\text { Pollution } \\
\text { tolerant }\end{array}$ & $\begin{array}{l}\text { Pollution } \\
\text { moderate }\end{array}$ & $\begin{array}{l}\text { Pollution } \\
\text { sensitive }\end{array}$ & $\begin{array}{l}\text { Pollution } \\
\text { tolerance } \\
\text { unknown }\end{array}$ & $\begin{array}{l}\text { Halobiontic } \\
\text { diatoms }\end{array}$ & $\begin{array}{c}\text { Fresh- } \\
\text { brackish } \\
\text { water } \\
\text { diatoms }\end{array}$ & $\begin{array}{c}\text { Freshwater } \\
\text { diatoms }\end{array}$ \\
\hline \multicolumn{14}{|c|}{ Honey Creek at Wauwatosa (USGS station 04087119) } \\
\hline 2004 & 35 & 57.4 & 0.12 & 1.71 & 0 & 96.0 & 8.33 & 60.0 & 28.7 & 3.00 & 37.3 & 60.3 & 0.17 \\
\hline 2007 & 29 & 21,965 & 8.6 & 1.55 & 0.38 & 98.3 & 8.41 & 70.5 & 19.4 & 1.68 & 51.7 & 46.9 & 0.61 \\
\hline 2010 & 43 & 16,964 & 2.4 & 2.34 & 1.6 & 98.8 & 19.7 & 72.8 & 6.50 & 1.00 & 61.2 & 38.2 & 0.33 \\
\hline 2013 & 41 & 19,813 & 1.2 & 2.13 & 12 & 98.2 & 12.3 & 57.7 & 29.3 & 0.67 & 49.3 & 50.3 & 0.17 \\
\hline Difference & 17 & 34,400 & 890 & 24.8 & 12 & 2.17 & 4.00 & -2.33 & 0.67 & -2.33 & 12.0 & -10.0 & 0.0 \\
\hline \multicolumn{14}{|c|}{ Menomonee River at Wauwatosa (USGS station 04087120) } \\
\hline 2004 & 36 & 1,241 & 21 & 1.15 & 0 & 93.1 & 8.36 & 58.7 & 27.9 & 5.08 & 51.6 & 42.1 & 0.16 \\
\hline 2007 & 32 & 3,752 & 12 & 1.67 & 8.4 & 96.8 & 11.1 & 76.3 & 9.42 & 3.19 & 73.7 & 23.1 & 0.46 \\
\hline 2010 & 44 & 694.1 & 7.4 & 2.61 & 5.8 & 70.0 & 11.7 & 49.2 & 11.5 & 27.7 & 43.8 & 28.2 & 13 \\
\hline 2013 & 42 & 57,086 & 5.5 & 1.36 & 4.2 & 89.0 & 11.0 & 73.7 & 7.50 & 7.83 & 70.2 & 22.0 & 0.0 \\
\hline Difference & 17 & 4,500 & -74 & 19.0 & 4.2 & -4.11 & 2.64 & 15.0 & -20.4 & 2.75 & 18.5 & -20.1 & -0.16 \\
\hline \multicolumn{14}{|c|}{ Kinnickinnic River at South 11th Street at Milwaukee (USGS station 04087159) } \\
\hline 2004 & 37 & 277.4 & 3.2 & 1.41 & 0 & 80.4 & 28.3 & 41.3 & 19.3 & 11.1 & 40.8 & 44.3 & 0.0 \\
\hline 2007 & 26 & 4,417 & 2.4 & 1.42 & 0.26 & 98.9 & 15.9 & 22.6 & 60.1 & 1.44 & 11.9 & 87.0 & 0.0 \\
\hline 2010 & 40 & 12,521 & 3.0 & 2.55 & 2.9 & 85.5 & 29.0 & 35.0 & 23.0 & 13.0 & 16.8 & 70.0 & 0.17 \\
\hline 2013 & 38 & 31,309 & 1.1 & 1.58 & 3.5 & 94.8 & 17.0 & 67.2 & 11.7 & 4.17 & 61.3 & 34.8 & 0.0 \\
\hline Difference & 2.7 & 11,190 & -66 & 12.0 & 3.5 & 14.5 & -11.3 & 25.9 & -7.63 & -6.98 & 20.6 & -9.43 & 0.0 \\
\hline \multicolumn{14}{|c|}{ Oak Creek at South Milwaukee (USGS station 04087204) } \\
\hline 2004 & 37 & 445.7 & 4.3 & 2.08 & 0 & 94.0 & 8.75 & 52.2 & 31.0 & 8.10 & 48.6 & 46.8 & 0.32 \\
\hline 2007 & 48 & 3,565 & 2.7 & 2.76 & 0 & 94.9 & 15.7 & 45.2 & 24.8 & 14.4 & 27.9 & 65.2 & 2.6 \\
\hline 2010 & 61 & 57,285 & 5.5 & 2.61 & 1.5 & 87.5 & 4.83 & 48.0 & 28.2 & 19.0 & 25.3 & 64.3 & 0.50 \\
\hline 2013 & 63 & 1,711 & 2.6 & 2.50 & 0 & 94.5 & 5.03 & 40.0 & 45.5 & 9.50 & 22.3 & 72.5 & 1.3 \\
\hline Difference & 70 & 283.9 & -41 & 20.2 & 0.0 & 0.50 & -3.75 & -12.2 & 14.5 & 1.40 & -26.3 & 25.7 & 1.0 \\
\hline
\end{tabular}


Table 2. Algal-assemblage information from surveys completed in 2004, 2007, 2010, and 2013 at 14 stream sites in the Milwaukee Metropolitan Sewerage District planning area, Wisconsin.-Continued

[The percentage of nuisance algae is the sum of benthic and sestonic algal producers (Porter, 2008); the percentage of eutrophic diatoms is the sum of mesotrophic-eutrophic, eutrophic, polytrophic, and eurytrophic diatoms (van Dam and others, 1994); the percentage of relative abundance of diatoms is based on Bahls (1993). The percentage of difference in metric values between 2013 and 2004 is shown (Difference), and percentages greater than 10 percent are highlighted; yellow denotes a potentially adverse difference, and blue denotes a potentially beneficial difference; and gray denotes a difference of unknown effect; $\mu \mathrm{L}$, microliter; $\mathrm{cm}^{2}$, square centimeter; USGS, U.S. Geological Survey; --, no data or not applicable]

\begin{tabular}{|c|c|c|c|c|c|c|c|c|c|c|c|c|c|}
\hline \multirow[b]{2}{*}{$\begin{array}{l}\text { Sampling } \\
\text { year }\end{array}$} & \multirow[b]{2}{*}{$\begin{array}{l}\text { Number } \\
\text { of taxa }\end{array}$} & \multirow[b]{2}{*}{$\begin{array}{c}\text { Biovolume } \\
\left(\mu \mathrm{L} / \mathrm{cm}^{2} \times 10^{6}\right)\end{array}$} & \multirow[b]{2}{*}{$\begin{array}{c}\text { Cell density } \\
(\text { cells/cm²×106) }\end{array}$} & \multirow[b]{2}{*}{$\begin{array}{l}\text { Shannon } \\
\text { index of } \\
\text { diversity }\end{array}$} & \multirow[b]{2}{*}{$\begin{array}{l}\text { Nuisance } \\
\text { algae } \\
\text { (percent) }\end{array}$} & \multicolumn{8}{|c|}{ Percentage of relative abundance of diatoms } \\
\hline & & & & & & Eutrophic & $\begin{array}{l}\text { Pollution } \\
\text { tolerant }\end{array}$ & $\begin{array}{l}\text { Pollution } \\
\text { moderate }\end{array}$ & $\begin{array}{l}\text { Pollution } \\
\text { sensitive }\end{array}$ & $\begin{array}{l}\text { Pollution } \\
\text { tolerance } \\
\text { unknown }\end{array}$ & $\begin{array}{c}\text { Halobiontic } \\
\text { diatoms }\end{array}$ & $\begin{array}{c}\text { Fresh- } \\
\text { brackish } \\
\text { water } \\
\text { diatoms }\end{array}$ & $\begin{array}{c}\text { Freshwater } \\
\text { diatoms }\end{array}$ \\
\hline \multicolumn{14}{|c|}{ Root River at Grange Avenue at Greenfield (USGS station 04087214) } \\
\hline 2004 & 28 & 1,018 & 2.3 & 0.72 & 0 & 92.0 & 5.83 & 38.7 & 43.3 & 12.2 & 24.0 & 61.0 & 7.8 \\
\hline 2007 & 30 & 1,476 & 3.2 & 1.95 & 0 & 98.9 & 3.76 & 24.4 & 56.0 & 15.9 & 16.9 & 67.6 & 15 \\
\hline 2010 & 62 & 432.9 & 1.1 & 2.24 & 0 & 90.2 & 3.83 & 34.8 & 49.7 & 11.7 & 13.8 & 76.5 & 7.5 \\
\hline 2013 & 70 & 469.9 & 2.0 & 2.23 & 0 & 84.8 & 7.83 & 25.8 & 49.2 & 17.2 & 19.0 & 64.0 & 3.7 \\
\hline Difference & 150 & -53.9 & -13 & 210. & 0.0 & -7.15 & 2.00 & -12.8 & 5.83 & 5.00 & -5.00 & 3.00 & -4.2 \\
\hline \multicolumn{14}{|c|}{ Root River near Franklin (USGS station 04087220) } \\
\hline 2004 & 33 & 946.9 & 3.2 & 1.24 & 0 & 94.8 & 17.0 & 15.8 & 60.5 & 6.67 & 14.0 & 79.0 & 3.5 \\
\hline 2007 & 49 & 2,690 & 6.1 & 3.01 & 0 & 90.8 & 10.3 & 29.7 & 47.4 & 12.5 & 14.5 & 75.6 & 2.3 \\
\hline 2010 & 51 & 618.3 & 5.2 & 2.03 & 0 & 86.5 & 11.2 & 27.0 & 50.3 & 11.5 & 8.83 & 80.8 & 1.3 \\
\hline 2013 & 63 & 1,611 & 2.9 & 2.16 & 0.81 & 88.7 & 7.83 & 29.7 & 52.5 & 10.0 & 16.8 & 73.2 & 0.83 \\
\hline Difference & 91 & 70.2 & -7.9 & 75.0 & 0.81 & -6.17 & -9.17 & 13.8 & -8.00 & 3.33 & 2.83 & -5.83 & -2.7 \\
\hline \multicolumn{14}{|c|}{ Jewel Creek at Muskego (USGS station 05544371) } \\
\hline 2004 & 40 & 1,472 & 2.7 & 2.17 & 0 & 78.8 & 3.00 & 11.7 & 67.2 & 18.2 & 12.7 & 68.3 & 0.50 \\
\hline 2007 & 50 & 4,075 & 8.5 & 2.18 & 0 & 85.9 & 1.82 & 17.4 & 65.5 & 15.3 & 10.6 & 75.1 & 1.3 \\
\hline 2010 & 65 & 44,710 & 2.7 & 2.53 & 2.5 & 89.7 & 4.50 & 27.7 & 60.0 & 7.83 & 7.83 & 82.8 & 1.5 \\
\hline 2013 & 69 & 91,031 & 4.8 & 2.09 & 0.76 & 90.5 & 6.67 & 19.8 & 66.0 & 7.50 & 9.00 & 84.2 & 0.67 \\
\hline Difference & 73 & 6,086 & 74 & -3.83 & 0.76 & 11.7 & 3.67 & 8.17 & -1.17 & -10.7 & -3.67 & 15.8 & 0.17 \\
\hline
\end{tabular}


(median of 50 taxa per site) compared with 2004 (median of 37 taxa per site). The most taxa collected from any site in 2013 were from the Root River at Greenfield site, and in 2004, the most taxa were collected from the Milwaukee River at Milwaukee site. The fewest taxa collected from any site in 2013 were from the Menomonee River at Menomonee Falls site, and in 2004, the fewest taxa were collected from the Root River at Greenfield site. At the three temporal sites where spring and fall samples were collected in 2011-13, the highest numbers of taxa were measured in fall compared to spring. Sample collections were focused on fall because streams were generally more wadable at late summer/early fall base flow. This finding emphasizes the need to standardize the sampling period and the need to sample multiple years when evaluating stream algal assemblages.

A total of 4 major algal groups (phyla) were identified among the 14 sites: diatoms and green, blue-green (also known as cyanobacteria), and red algae. All 4 groups were present at 8 sites in 2013 (table 3). Red algae were missing at 5 sites and; red and green algae were missing at 1 site. In 2004, all 4 algal groups were present at only 2 sites (Honey Creek and Menomonee River at Wauwatosa). Six sites were missing green algae and six sites were missing red algae. A total of 2 additional phyla (Euglenoids and Dinoflagellates) were identified at 3 sites in 2013 but relative abundance was about 1 percent or less at these sites. The percentage of relative abundance of each algal phylum was calculated by dividing the cell density of each taxon from that algal phylum by the total cell density for that site.

Algal biovolume at most sites was higher in 2013 compared with 2004 (table 2). The total biovolume of algae summed for all 14 sites was 80 percent higher in 2013 than 2004 with 375 billion compared with 208 billion cubic microliters per square centimeter, respectively. More than half of the total biovolume of algae in 2013 can be attributed to Milwaukee River near Cedarburg and Jewel Creek, most of which is accounted for by the Cladophora glomerata (green algae). This green alga occurred at 7 of the 14 sites in 2013 (Honey Creek, Jewel Creek, Kinnickinnic River, Milwaukee River near Cedarburg, Menomonee River at Menomonee Falls, Menomonee River at Wauwatosa, and Underwood Creek) and accounted for more than 90 percent of the total algal biovolume at the 14 sites.

Diversity in 2013 compared with 2004 was improved at seven sites and unchanged at the other seven sites. Diversity improved from high stress (diversity index $<1.5$, low richness with highly uneven abundance) in 2004 to moderate stress (diversity index $=1.5-2.5$, medium richness with medium evenness of abundance) in 2013 for seven sites based on diversity rankings for diatoms in low-gradient streams according to Bahls (1993). Six sites were rated moderate stress for 2004 and 2013 and the Menomonee River at Wauwatosa site was rated high stress in 2004 and 2013.

There was little difference in the percentage of nuisance algae between 2004 and 2013 at most sites (table 2). Only one site, Honey Creek, was more than 10 percent higher in 2013
(12) compared with 2004 (0). The percentage of relative abundance of eutrophic diatoms was at least 10 percent higher at four sites in 2013 compared with 2004 (Milwaukee River near Cedarburg [15.0], Willow Creek [21.2], Kinnickinnic River [14.5], and Jewel Creek [11.7]; table 2). Increases in nuisance algae and eutrophic diatoms indicate higher overall concentrations of nutrients at these streams.

For some sites, large differences in abundance were detected between 2004 and 2013 for pollution-tolerant and pollution-sensitive diatoms (table 2, fig. $3 \mathrm{~A}$ ). A greater abundance of pollution-tolerant diatoms indicates degradation of water quality at a site. The relative abundance of pollutiontolerant diatoms in 2013 was higher at 11 of the 14 sites and changes greater than 10 percent occurred at 2 sites (Lincoln Creek and Milwaukee River at Milwaukee). The only stream to have a relatively large negative difference in pollutiontolerant diatoms was the Kinnickinnic River, from 28 percent in 2004 to 17 percent in 2013, and this may indicate improvement in water quality. Three sites had substantial (greater than [ $>10$ percent) increases in pollution-sensitive diatoms (Lincoln Creek, Little Menomonee River, and Oak Creek) and three sites had substantial (>10 percent) decreases in pollutionsensitive diatoms (Willow Creek, Underwood Creek, and Menomonee River at Wauwatosa). Five sites in 2013 (Lincoln Creek, Underwood Creek, Honey Creek, Menomonee River at Wauwatosa, and the Kinnickinnic River) all had less than 30-percent pollution-sensitive diatoms (fig. 4). All sites except Underwood Creek had less than 30-percent pollution-sensitive diatoms in 2004 too. Lange-Bertalot (1979) developed a pollution-tolerance index based on diatom studies in Europe that was later the basis of a multimetric diatom index for water quality by Bahls (1993). Lange-Bertalot (1979) determined that pollution-sensitive diatoms were dominant where water quality was only moderately polluted by nutrients (mean 5-day biological oxygen demand [BOD5] less than 4 milligrams per liter [mg/L] DO); however, decreases in the dominance by pollution-sensitive diatoms in favor of more pollutionmoderate and pollution-tolerant diatoms indicated degradation of water quality to eutrophic or highly eutrophic conditions. Bahls (1993) determined a mean percentage of relative abundance of 32 percent for plains-ecoregion reference streams in Montana. The abundance of sensitive diatoms was determined by Porter and others (2008) to decrease with increasing phosphorus concentration. In the current study, the lack of dominance by pollution-sensitive diatoms and less than 30-percent relative abundance indicates that water quality at five sites was degraded, possibly because of excess nutrients that can lead to high oxygen demand and eutrophication. Not surprisingly, the more urban sites in the central part of the Milwaukee metropolitan area (Lincoln Creek, Milwaukee River at Milwaukee, Little Menomonee River at Milwaukee, Underwood Creek, Honey Creek, Menomonee River at Wauwatosa, Kinnickinnic River, and Oak Creek at South Milwaukee) had significantly $(p<0.05)$ fewer pollution-sensitive diatoms than sites in more outlying areas of the metropolitan area (Milwaukee River near Cedarburg, Willow Creek, Menomonee River at Menomonee 
Table 3. Comparison of algal-assemblage data at 14 stream sites in the Milwaukee Metropolitan Sewerage District planning area, Wisconsin, $2004-13$.

[Unknown taxa were not included in the percentage of relative abundance of algae and the percentage of biovolume of algae calculations. The percentage of differences in metric values between fall 2013 and fall 2004 is shown (Difference), and percentages greater than 10 percent are highlighted; yellow denotes a potentially adverse difference, blue denotes a potentially beneficial difference; and gray denotes a difference of unknown effect. USGS, U.S. Geological Survey; <, less than]

\begin{tabular}{|c|c|c|c|c|c|c|c|c|c|c|c|c|}
\hline \multirow{2}{*}{$\begin{array}{c}\text { Sampling } \\
\text { year }\end{array}$} & \multicolumn{6}{|c|}{ Percentage of relative abundance of algae (percent cell density) } & \multicolumn{6}{|c|}{ Percentage of biovolume of algae } \\
\hline & Diatoms & $\begin{array}{l}\text { Green } \\
\text { algae }\end{array}$ & $\begin{array}{c}\text { Blue-green } \\
\text { algae }\end{array}$ & $\begin{array}{c}\text { Red } \\
\text { algae }\end{array}$ & Euglenoids & Dinoflagellates & Diatoms & $\begin{array}{l}\text { Green } \\
\text { algae }\end{array}$ & $\begin{array}{c}\text { Blue-green } \\
\text { algae }\end{array}$ & $\begin{array}{c}\text { Red } \\
\text { algae }\end{array}$ & Euglenoids & Dinoflagellates \\
\hline \multicolumn{13}{|c|}{ Milwaukee River near Cedarburg (USGS station 04086600) } \\
\hline 2004 & 16.1 & 0.405 & 83.5 & 0.0 & 0.0 & 0.0 & 11.8 & 86.5 & 1.76 & 0.007 & 0.0 & 0.0 \\
\hline 2007 & 11.0 & 3.03 & 86.0 & 0.0 & 0.0 & 0.0 & 14.7 & 77.6 & 7.73 & 0.007 & 0.0 & 0.0 \\
\hline 2010 & 9.69 & 3.90 & 85.1 & 1.32 & 0.0 & 0.0 & 7.95 & 85.8 & 5.55 & 0.650 & 0.0 & 0.0 \\
\hline 2013 & 5.65 & 7.20 & 86.8 & 0.40 & 0.0 & 0.0 & 0.143 & 99.7 & 0.125 & 0.007 & 0.0 & 0.0 \\
\hline Difference & -10.5 & 6.79 & 3.30 & 0.40 & 0.0 & 0.0 & -11.6 & 13.3 & -1.63 & 0.0 & 0.0 & 0.0 \\
\hline \multicolumn{13}{|c|}{ Lincoln Creek at 47th Street at Milwaukee (USGS station 040869415) } \\
\hline 2004 & 6.27 & 3.65 & 90.1 & 0.0 & 0.0 & 0.0 & 0.474 & 0.062 & 99.5 & 0.007 & 0.0 & 0.0 \\
\hline 2007 & 7.02 & 14.0 & 79.0 & 0.0 & 0.0 & 0.0 & 0.517 & 99.0 & 0.528 & 0.007 & 0.0 & 0.0 \\
\hline 2010 & 12.3 & 12.2 & 59.9 & 15.5 & 0.0 & 0.0 & 4.60 & 55.5 & 1.89 & 38.0 & 0.0 & 0.0 \\
\hline 2013 & 10.0 & 10.1 & 79.9 & 0.0 & 0.0 & 0.0 & 2.07 & 11.3 & 86.7 & 0.007 & 0.0 & 0.0 \\
\hline Difference & 3.71 & 6.43 & -10.1 & 0.0 & 0.0 & 0.0 & 1.60 & 11.2 & -12.8 & 0.0 & 0.0 & 0.0 \\
\hline \multicolumn{13}{|c|}{ Milwaukee River at Milwaukee (USGS station 04087000) } \\
\hline 2004 & 26.4 & 1.14 & 72.5 & 0.0 & 0.0 & 0.0 & 1.69 & 0.037 & 98.3 & 0.007 & 0.0 & 0.0 \\
\hline 2007 & 20.1 & 9.54 & 70.3 & 0.0 & 0.0 & 0.0 & 15.9 & 79.9 & 4.23 & 0.007 & 0.0 & 0.0 \\
\hline 2010 & 7.59 & 3.82 & 87.6 & 0.97 & 0.0 & 0.0 & 58.5 & 29.0 & 10.5 & 2.03 & 0.0 & 0.0 \\
\hline 2013 & 5.95 & 2.46 & 87.5 & 4.11 & 0.0 & 0.0 & 32.0 & 41.8 & 15.3 & 10.8 & 0.0 & 0.0 \\
\hline Difference & -20.4 & 1.33 & 15.0 & 4.11 & 0.0 & 0.0 & 30.3 & 41.8 & -82.9 & 10.8 & 0.0 & 0.0 \\
\hline \multicolumn{13}{|c|}{ Willow Creek at Maple Road, near Germantown (USGS station 040870195) } \\
\hline 2004 & 58.7 & 1.42 & 39.8 & 0.0 & 0.0 & 0.0 & 53.5 & 43.7 & 2.82 & 0.007 & 0.0 & 0.0 \\
\hline 2007 & 23.9 & 5.41 & 64.9 & 5.80 & 0.0 & 0.0 & 2.55 & 95.3 & 1.18 & 1.01 & 0.0 & 0.0 \\
\hline 2010 & 34.6 & 0.0 & 63.8 & 1.56 & 0.0 & 0.0 & 68.5 & 0.007 & 27.0 & 4.50 & 0.0 & 0.0 \\
\hline 2013 & 18.2 & 5.23 & 68.6 & 7.92 & 0.0 & 0.0 & 29.3 & 28.6 & 18.1 & 24.1 & 0.0 & 0.0 \\
\hline Difference & -40.5 & 3.81 & 28.8 & 7.92 & 0.0 & 0.0 & -24.2 & -15.1 & 15.3 & 24.1 & 0.0 & 0.0 \\
\hline
\end{tabular}


Table 3. Comparison of algal-assemblage data at 14 stream sites in the Milwaukee Metropolitan Sewerage District planning area, Wisconsin, 2004-13.-Continued

[Unknown taxa were not included in the percentage of relative abundance of algae and the percentage of biovolume of algae calculations. The percentage of differences in metric values between fall 2013 and fall 2004 is shown (Difference), and percentages greater than 10 percent are highlighted; yellow denotes a potentially adverse difference, blue denotes a potentially beneficial difference; and gray denotes a difference of unknown effect. USGS, U.S. Geological Survey; <, less than]

\begin{tabular}{|c|c|c|c|c|c|c|c|c|c|c|c|c|}
\hline \multirow{2}{*}{$\begin{array}{c}\text { Sampling } \\
\text { year }\end{array}$} & \multicolumn{6}{|c|}{ Percentage of relative abundance of algae (percent cell density) } & \multicolumn{6}{|c|}{ Percentage of biovolume of algae } \\
\hline & Diatoms & $\begin{array}{c}\text { Green } \\
\text { algae }\end{array}$ & $\begin{array}{c}\text { Blue-green } \\
\text { algae }\end{array}$ & $\begin{array}{c}\text { Red } \\
\text { algae }\end{array}$ & Euglenoids & Dinoflagellates & Diatoms & $\begin{array}{l}\text { Green } \\
\text { algae }\end{array}$ & $\begin{array}{c}\text { Blue-green } \\
\text { algae }\end{array}$ & $\begin{array}{c}\text { Red } \\
\text { algae }\end{array}$ & Euglenoids & Dinoflagellates \\
\hline \multicolumn{13}{|c|}{ Menomonee River at Menomonee Falls (USGS station 04087030) } \\
\hline 2004 & 30.2 & 0.0 & 53.0 & 16.8 & 0.0 & 0.0 & 47.9 & 0.0 & 2.80 & 49.3 & 0.0 & 0.0 \\
\hline 2007 & 15.1 & 5.21 & 75.3 & 4.33 & 0.0 & 0.0 & 50.6 & 23.9 & 13.3 & 12.2 & 0.0 & 0.0 \\
\hline 2010 & 20.8 & 3.96 & 41.4 & 33.7 & 0.0 & 0.0 & 26.3 & 8.24 & 10.3 & 55.1 & 0.0 & 0.0 \\
\hline 2013 & 1.35 & 5.40 & 74.3 & 19.0 & 0.0 & 0.029 & 0.057 & 97.3 & 0.732 & 1.90 & 0.0 & 0.1 \\
\hline Difference & -28.9 & 5.40 & 21.3 & 2.15 & 0.0 & 0.0 & -47.8 & 97.3 & -2.07 & -47.4 & 0.0 & 0.1 \\
\hline \multicolumn{13}{|c|}{ Little Menomonee River at Milwaukee (USGS station 04087070) } \\
\hline 2004 & 22.3 & 0.0 & 70.0 & 7.64 & 0.0 & 0.0 & 55.1 & 0.007 & 5.41 & 39.5 & 0.0 & 0.0 \\
\hline 2007 & 11.3 & 4.52 & 79.5 & 4.69 & 0.0 & 0.0 & 9.69 & 62.4 & 16.9 & 11.0 & 0.0 & 0.0 \\
\hline 2010 & 14.4 & 1.23 & 84.4 & 0.0 & 0.0 & 0.0 & 27.0 & 25.6 & 47.4 & 0.007 & 0.0 & 0.0 \\
\hline 2013 & 21.6 & 0.0 & 78.4 & 0.0 & 0.0 & 0.0 & 58.2 & 0.007 & 41.8 & 0.007 & 0.0 & 0.0 \\
\hline Difference & -0.80 & $\mathbf{0 . 0}$ & 8.44 & -7.64 & $\mathbf{0 . 0}$ & $\mathbf{0 . 0}$ & 3.09 & $\mathbf{0 . 0}$ & 36.4 & -39.5 & $\mathbf{0 . 0}$ & $\mathbf{0 . 0}$ \\
\hline \multicolumn{13}{|c|}{ Underwood Creek at Wauwatosa (USGS station 04087088) } \\
\hline 2004 & 8.09 & 1.88 & 90.0 & 0.0 & 0.0 & 0.0 & 47.1 & 4.93 & 47.9 & 0.007 & 0.0 & 0.0 \\
\hline 2007 & 14.7 & 2.80 & 82.5 & 0.0 & 0.0 & 0.0 & 23.6 & 19.0 & 57.4 & 0.007 & 0.0 & 0.0 \\
\hline 2010 & 31.4 & 4.76 & 63.8 & 0.0 & 0.0 & 0.0 & 94.8 & 1.31 & 3.93 & 0.007 & 0.0 & 0.0 \\
\hline 2013 & 11.1 & 12.7 & 76.2 & 0.0 & 0.0 & 0.0 & 0.091 & 99.8 & 0.157 & 0.007 & 0.0 & 0.0 \\
\hline Difference & 3.02 & 10.8 & -13.9 & 0.0 & 0.0 & 0.0 & -47.1 & 94.8 & -47.8 & 0.0 & 0.0 & 0.0 \\
\hline \multicolumn{13}{|c|}{ Honey Creek at Wauwatosa (USGS station 04087119) } \\
\hline 2004 & 44.3 & 0.400 & 28.4 & 26.9 & 0.0 & 0.0 & 71.9 & 0.800 & 0.800 & 26.6 & 0.0 & 0.0 \\
\hline 2007 & 16.4 & 2.95 & 80.6 & 0.0 & 0.0 & 0.0 & 1.07 & 98.3 & 0.628 & 0.007 & 0.0 & 0.0 \\
\hline 2010 & 39.6 & 12.9 & 43.5 & 3.86 & 0.1 & 0.0 & 0.593 & 99.1 & 0.061 & 0.248 & 0.02 & 0.0 \\
\hline 2013 & 21.0 & 17.5 & 61.5 & 0.0 & 0.0 & 0.0 & 0.305 & 99.6 & 0.082 & 0.007 & 0.0 & 0.0 \\
\hline Difference & -23.3 & 17.1 & 33.1 & -26.9 & 0.0 & 0.0 & -71.6 & 98.8 & -0.718 & -26.6 & 0.0 & 0.0 \\
\hline
\end{tabular}


Table 3. Comparison of algal-assemblage data at 14 stream sites in the Milwaukee Metropolitan Sewerage District planning area, Wisconsin, 2004-13.-Continued

[Unknown taxa were not included in the percentage of relative abundance of algae and the percentage of biovolume of algae calculations. The percentage of differences in metric values between fall 2013 and fall 2004 is shown (Difference), and percentages greater than 10 percent are highlighted; yellow denotes a potentially adverse difference, blue denotes a potentially beneficial difference; and gray denotes a difference of unknown effect. USGS, U.S. Geological Survey; <, less than]

\begin{tabular}{|c|c|c|c|c|c|c|c|c|c|c|c|c|}
\hline \multirow{2}{*}{$\begin{array}{c}\text { Sampling } \\
\text { year }\end{array}$} & \multicolumn{6}{|c|}{ Percentage of relative abundance of algae (percent cell density) } & \multicolumn{6}{|c|}{ Percentage of biovolume of algae } \\
\hline & Diatoms & $\begin{array}{l}\text { Green } \\
\text { algae }\end{array}$ & $\begin{array}{c}\text { Blue-green } \\
\text { algae }\end{array}$ & $\begin{array}{c}\text { Red } \\
\text { algae }\end{array}$ & Euglenoids & Dinoflagellates & Diatoms & $\begin{array}{l}\text { Green } \\
\text { algae }\end{array}$ & $\begin{array}{c}\text { Blue-green } \\
\text { algae }\end{array}$ & $\begin{array}{c}\text { Red } \\
\text { algae }\end{array}$ & Euglenoids & Dinoflagellates \\
\hline \multicolumn{13}{|c|}{ Menomonee River at Wauwatosa (USGS station 04087120) } \\
\hline 2004 & 8.26 & 0.169 & 91.0 & 0.59 & 0.0 & 0.0 & 47.5 & 0.095 & 47.9 & 4.59 & 0.0 & 0.0 \\
\hline 2007 & 20.2 & 8.41 & 69.6 & 1.74 & 0.0 & 0.0 & 6.38 & 84.5 & 6.40 & 2.75 & 0.0 & 0.0 \\
\hline 2010 & 39.8 & 6.71 & 53.5 & 0.0 & 0.0 & 0.0 & 65.4 & 30.1 & 4.49 & 0.007 & 0.0 & 0.0 \\
\hline 2013 & 7.47 & 6.11 & 86.3 & 0.0 & 0.2 & 0.0 & 0.0 & 99.8 & 0.118 & 0.007 & 0.04 & 0.0 \\
\hline Difference & -0.80 & 5.94 & -4.71 & -0.59 & 0.2 & 0.0 & -47.5 & 99.7 & -47.7 & -4.58 & 0.04 & 0.0 \\
\hline \multicolumn{13}{|c|}{ Kinnickinnic River at South 11th Street at Milwaukee (USGS station 04087159) } \\
\hline 2004 & 12.2 & 0.617 & 87.2 & 0.0 & 0.0 & 0.0 & 68.0 & 0.649 & 31.4 & 0.007 & 0.0 & 0.0 \\
\hline 2007 & 21.6 & 5.90 & 72.5 & 0.0 & 0.0 & 0.0 & 4.64 & 94.5 & 0.860 & 0.007 & 0.0 & 0.0 \\
\hline 2010 & 22.2 & 3.03 & 74.8 & 0.0 & 0.0 & 0.0 & 1.70 & 98.0 & 0.256 & 0.007 & 0.0 & 0.0 \\
\hline 2013 & 14.7 & 5.42 & 79.9 & 0.0 & 0.0 & 0.0 & 0.184 & 99.8 & $<0.041$ & 0.007 & 0.0 & 0.0 \\
\hline Difference & 2.49 & 4.80 & -7.30 & 0.0 & 0.0 & 0.0 & -67.8 & 99.1 & -31.3 & 0.0 & 0.0 & 0.0 \\
\hline \multicolumn{13}{|c|}{ Oak Creek at South Milwaukee (USGS station 04087204) } \\
\hline 2004 & 33.0 & 0.0 & 59.2 & 7.80 & 0.0 & 0.0 & 59.9 & 0.0 & 5.90 & 34.2 & 0.0 & 0.0 \\
\hline 2007 & 43.0 & 8.56 & 35.0 & 13.5 & 0.0 & 0.0 & 46.7 & 47.6 & 0.955 & 4.80 & 0.0 & 0.0 \\
\hline 2010 & 29.6 & 1.82 & 48.5 & 20.0 & 0.1 & 0.0 & 1.44 & 97.4 & 0.167 & 0.862 & 0.09 & 0.0 \\
\hline 2013 & 28.4 & 5.71 & 35.9 & 30.0 & 0.0 & 0.0 & 44.6 & 32.2 & 2.66 & 20.6 & 0.0 & 0.0 \\
\hline Difference & -4.58 & 5.71 & -23.3 & 22.2 & $\mathbf{0 . 0}$ & $\mathbf{0 . 0}$ & -15.3 & 32.2 & -3.24 & -13.6 & $\mathbf{0 . 0}$ & $\mathbf{0 . 0}$ \\
\hline \multicolumn{13}{|c|}{ Root River at Grange Avenue at Greenfield (USGS station 04087214) } \\
\hline 2004 & 10.2 & 0.0 & 2.88 & 86.9 & 0.0 & 0.0 & 10.8 & 0.0 & 0.305 & 88.9 & 0.0 & 0.0 \\
\hline 2007 & 30.4 & 21.8 & 6.18 & 41.6 & 0.0 & 0.0 & 19.9 & 37.5 & 0.191 & 42.5 & 0.0 & 0.0 \\
\hline 2010 & 18.0 & 0.435 & 47.0 & 34.6 & 0.0 & 0.0 & 26.1 & 25.2 & 7.56 & 41.1 & 0.0 & 0.0 \\
\hline 2013 & 11.4 & 3.89 & 60.9 & 23.7 & 0.1 & 0.0 & 24.4 & 17.7 & 11.4 & 46.0 & 0.49 & 0.0 \\
\hline Difference & 1.25 & 3.89 & 58.0 & -63.2 & 0.1 & 0.0 & 13.6 & 17.7 & 11.1 & -42.9 & 0.49 & 0.0 \\
\hline
\end{tabular}


Table 3. Comparison of algal-assemblage data at 14 stream sites in the Milwaukee Metropolitan Sewerage District planning area, Wisconsin, 2004-13.-Continued

[Unknown taxa were not included in the percentage of relative abundance of algae and the percentage of biovolume of algae calculations. The percentage of differences in metric values between fall 2013 and fall 2004 is shown (Difference), and percentages greater than 10 percent are highlighted; yellow denotes a potentially adverse difference, blue denotes a potentially beneficial difference; and gray denotes a difference of unknown effect. USGS, U.S. Geological Survey; <, less than]

\begin{tabular}{|c|c|c|c|c|c|c|c|c|c|c|c|c|}
\hline \multirow{2}{*}{$\begin{array}{c}\text { Sampling } \\
\text { year }\end{array}$} & \multicolumn{6}{|c|}{ Percentage of relative abundance of algae (percent cell density) } & \multicolumn{6}{|c|}{ Percentage of biovolume of algae } \\
\hline & Diatoms & $\begin{array}{l}\text { Green } \\
\text { algae }\end{array}$ & $\begin{array}{c}\text { Blue-green } \\
\text { algae }\end{array}$ & $\begin{array}{c}\text { Red } \\
\text { algae }\end{array}$ & Euglenoids & Dinoflagellates & Diatoms & $\begin{array}{l}\text { Green } \\
\text { algae }\end{array}$ & $\begin{array}{c}\text { Blue-green } \\
\text { algae }\end{array}$ & $\begin{array}{c}\text { Red } \\
\text { algae }\end{array}$ & Euglenoids & Dinoflagellates \\
\hline \multicolumn{13}{|c|}{ Root River near Franklin (USGS station 04087220) } \\
\hline 2004 & 11.2 & 0.0 & 37.1 & 51.7 & 0.0 & 0.0 & 17.3 & 0.007 & 4.38 & 78.3 & 0.0 & 0.0 \\
\hline 2007 & 46.7 & 3.17 & 33.8 & 16.4 & 0.0 & 0.0 & 71.1 & 5.69 & 5.68 & 17.5 & 0.0 & 0.0 \\
\hline 2010 & 12.9 & 1.14 & 77.1 & 8.87 & 0.0 & 0.0 & 22.0 & 8.20 & 36.1 & 33.7 & 0.0 & 0.0 \\
\hline 2013 & 17.8 & 2.43 & 63.6 & 15.5 & 0.6 & 0.0 & 9.79 & 67.7 & 6.90 & 12.9 & 2.7 & 0.0 \\
\hline Difference & 6.64 & 2.43 & 26.5 & -36.2 & 0.6 & 0.0 & -7.50 & 67.7 & 2.52 & -65.5 & 2.7 & 0.0 \\
\hline \multicolumn{13}{|c|}{ Jewel Creek at Muskego (USGS station 05544371) } \\
\hline 2004 & 38.5 & 0.0 & 19.9 & 41.6 & 0.0 & 0.0 & 63.6 & 0.0 & 1.30 & 35.1 & 0.0 & 0.0 \\
\hline 2007 & 28.1 & 12.8 & 17.5 & 41.6 & 0.0 & 0.0 & 35.8 & 21.2 & 1.76 & 41.2 & 0.0 & 0.0 \\
\hline 2010 & 38.9 & 2.76 & 38.2 & 19.4 & 0.3 & 0.5 & 1.82 & 97.5 & 0.177 & 0.520 & 0.03 & 0.01 \\
\hline 2013 & 22.3 & 1.19 & 46.2 & 29.1 & 1.3 & 0.0 & 9.31 & 89.6 & 0.170 & 0.700 & 0.19 & 0.0 \\
\hline Difference & -16.3 & 1.19 & 26.3 & -12.5 & 1.3 & 0.0 & -54.3 & 89.6 & -1.13 & -34.4 & 0.19 & 0.0 \\
\hline
\end{tabular}




\section{A. Diatom pollution class}
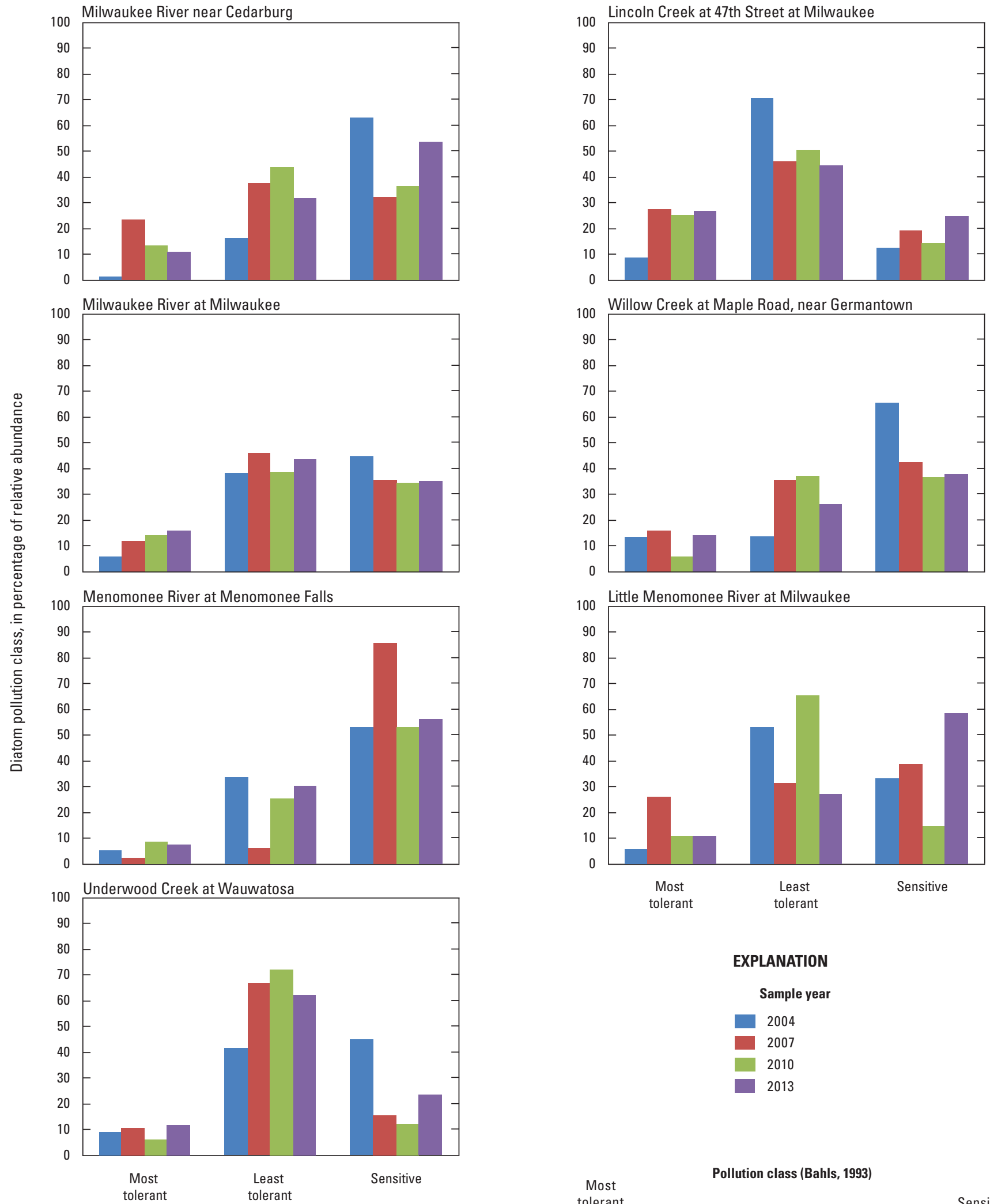

\section{EXPLANATION}

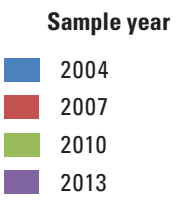

Most

Figure 3. Selected algal metrics for each of 14 stream sites in the Milwaukee area, Wisconsin, 2004-13. A, diatom pollution class; $B$, diatom salinity tolerance. 


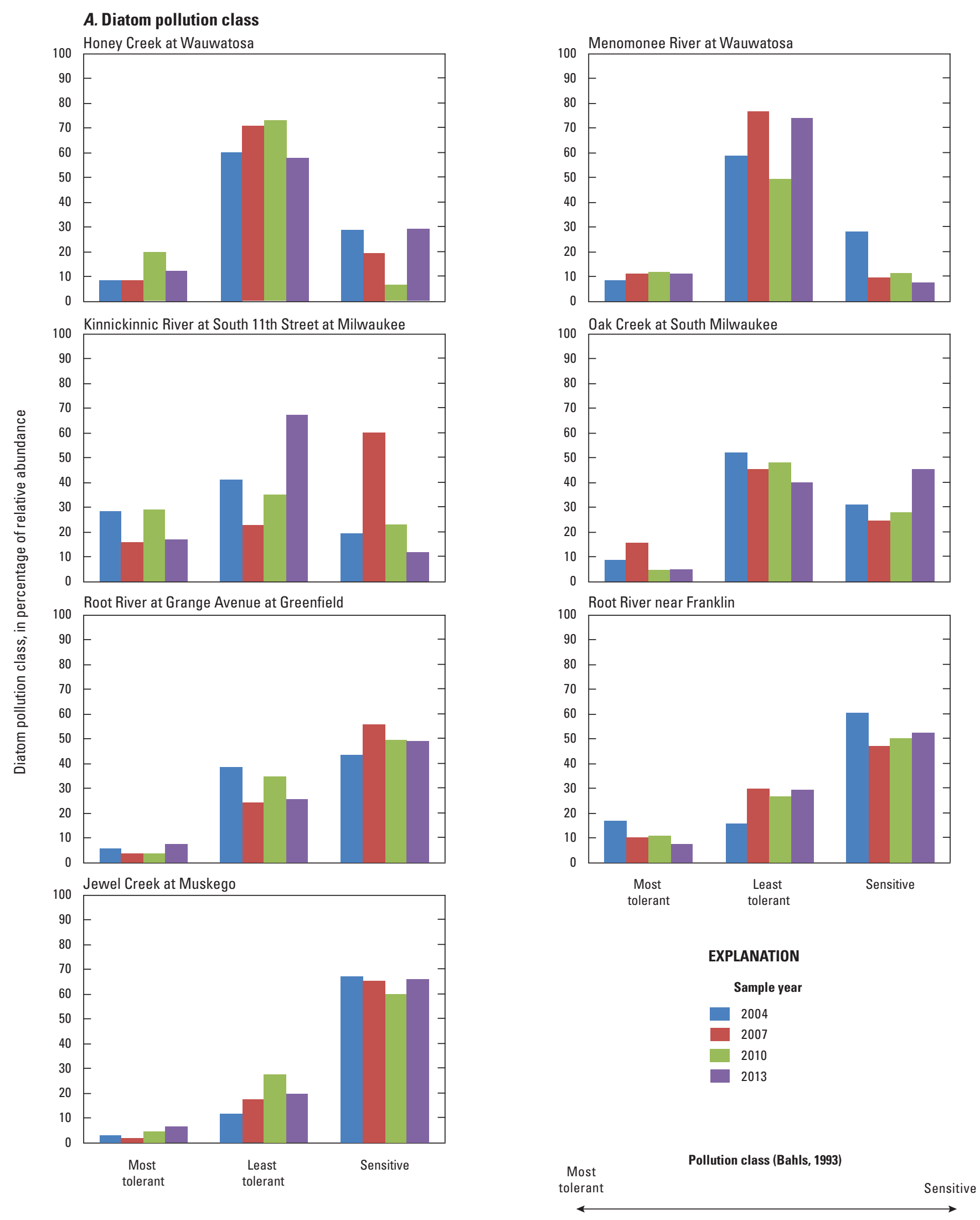

Figure 3. Selected algal metrics for each of 14 stream sites in the Milwaukee area, Wisconsin, 2004-13. A, diatom pollution class; $B$, diatom salinity tolerance.-Continued 
B. Diatom salinity tolerance
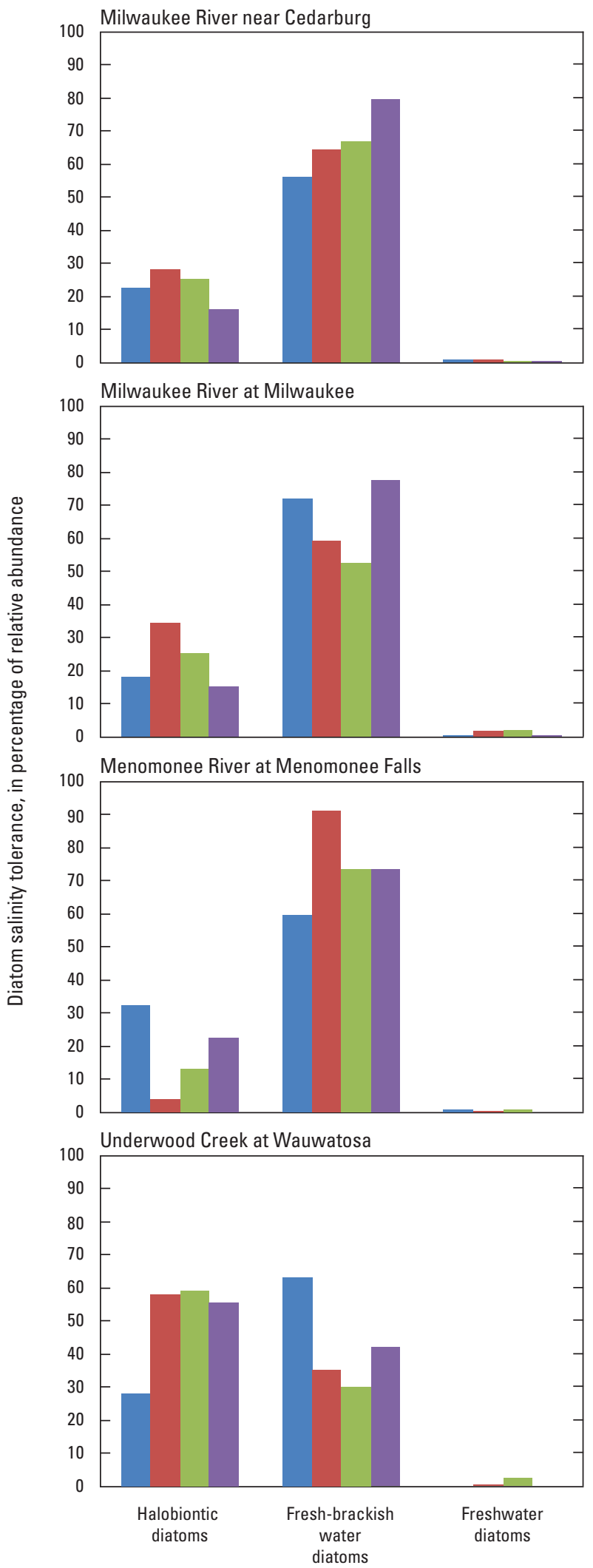
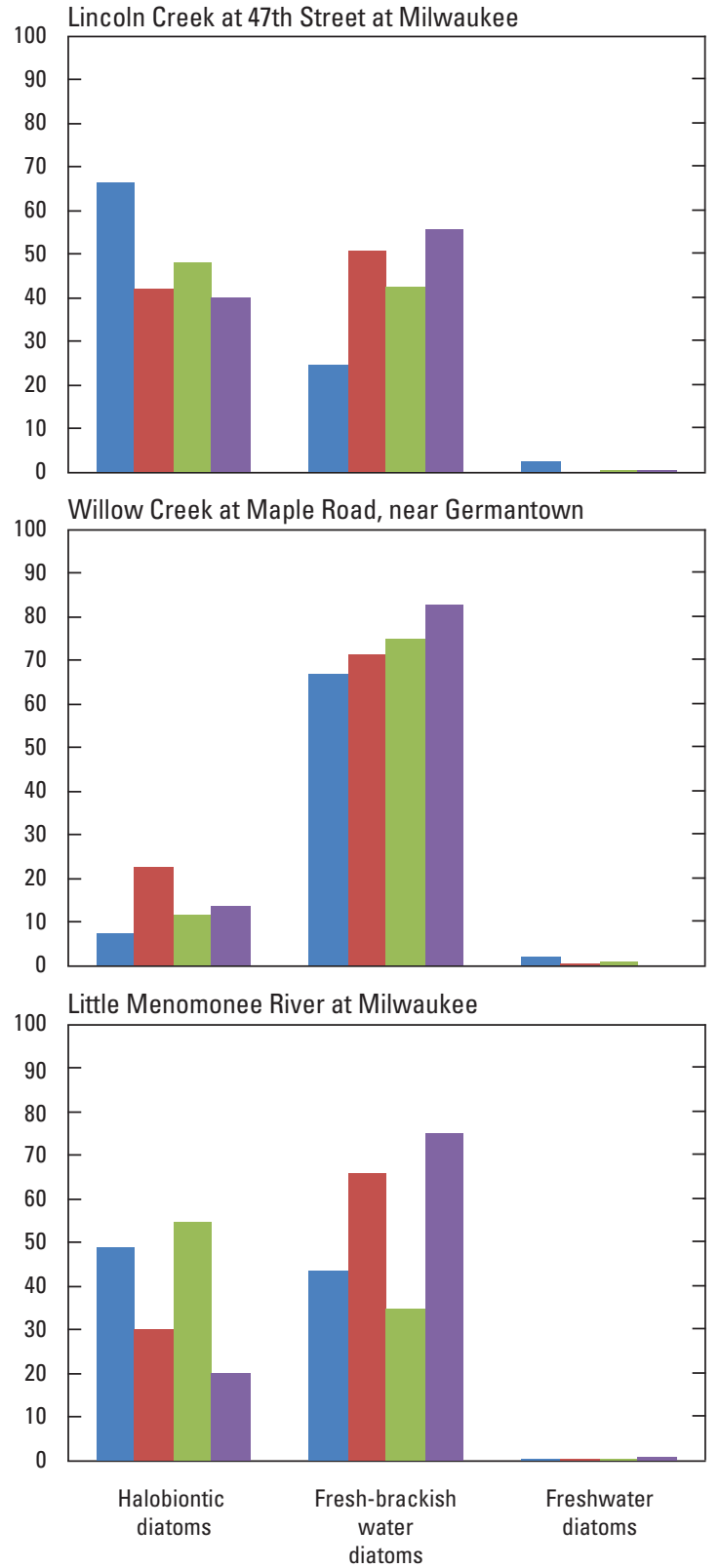

EXPLANATION

Sample year
2004
2007
2010
2013

High chloride tolerance

Salinity

Low chloride tolerance

Figure 3. Selected algal metrics for each of 14 stream sites in the Milwaukee area, Wisconsin, 2004-13. A, diatom pollution class; $B$, diatom salinity tolerance.-Continued 


\section{B. Diatom salinity tolerance}
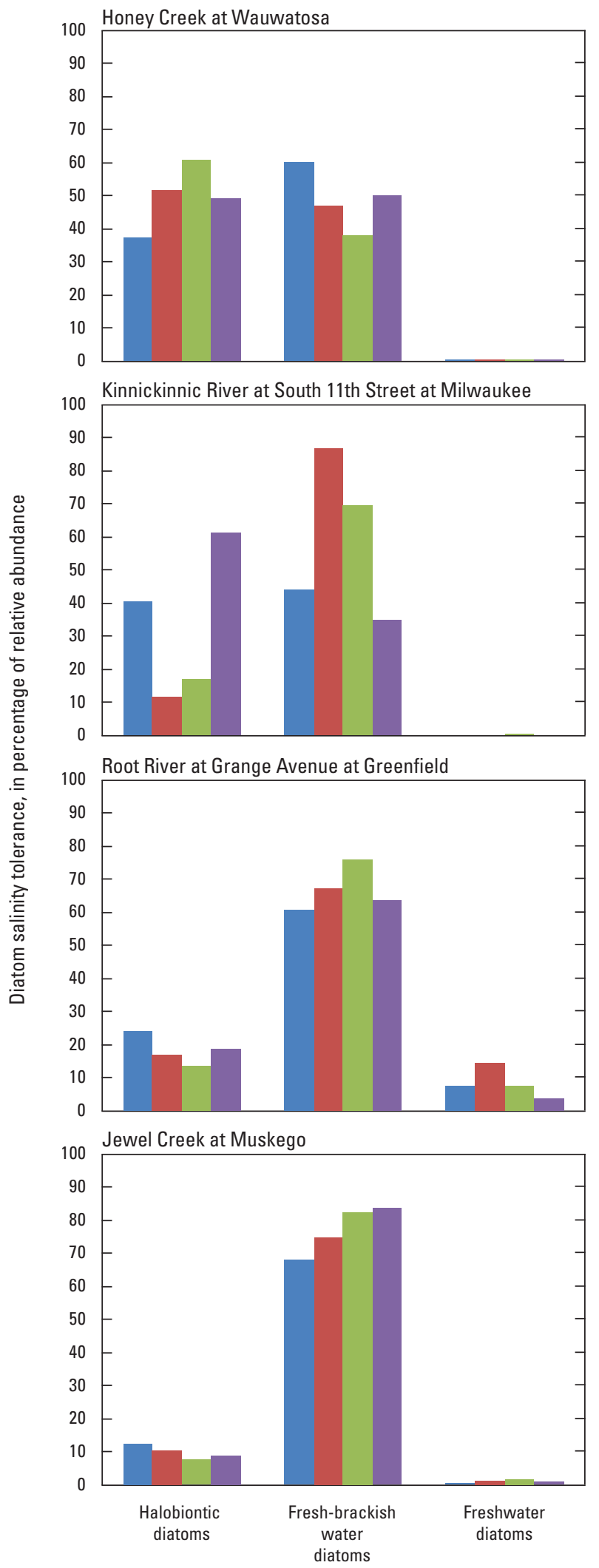
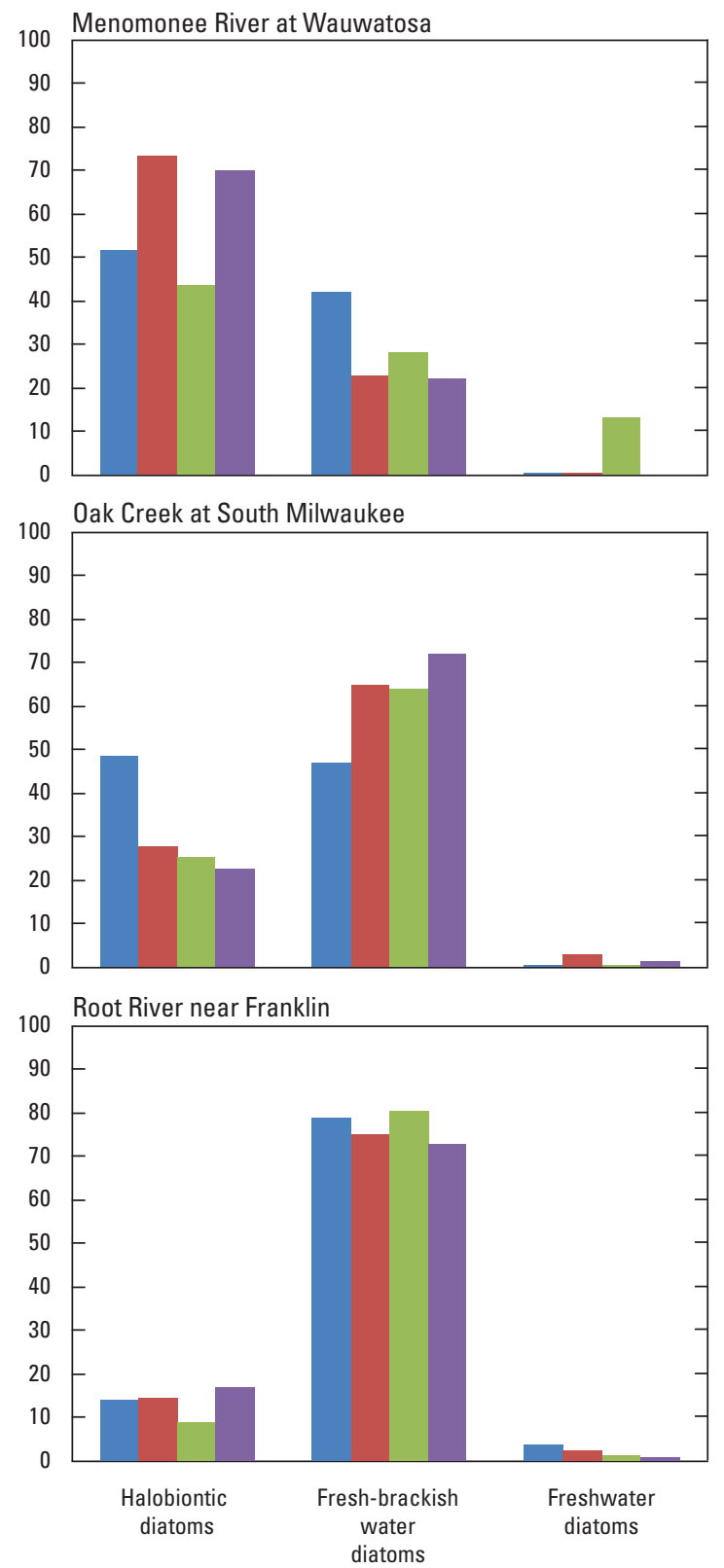

EXPLANATION

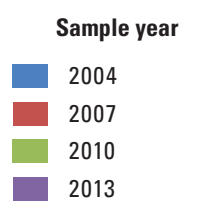

High chloride tolerance

Salinity

Low chloride tolerance

Figure 3. Selected algal metrics for each of 14 stream sites in the Milwaukee area, Wisconsin, 2004-13. A, diatom pollution class; $B$, diatom salinity tolerance.-Continued 


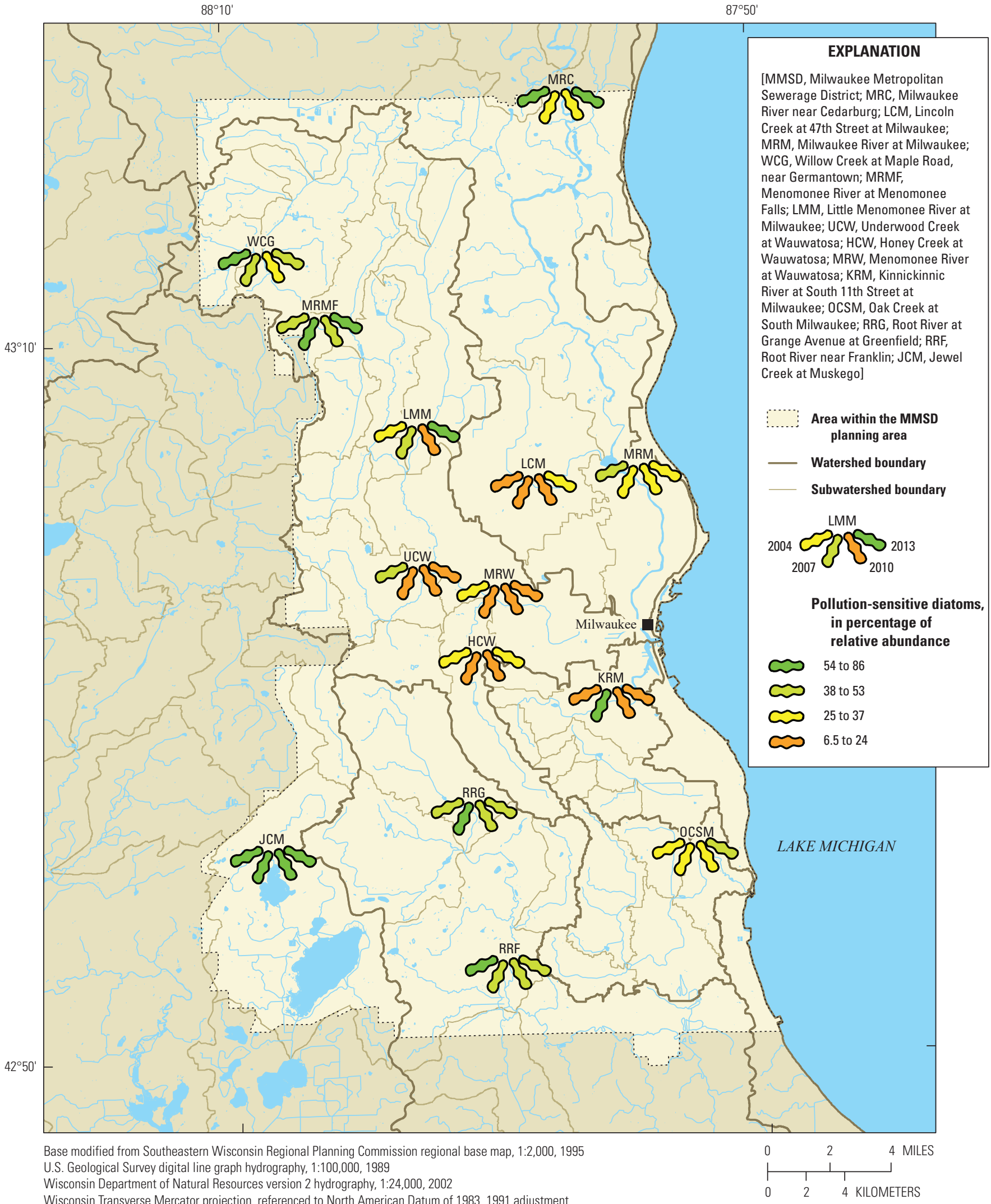

Figure 4. Pollution-sensitive diatom algae scores at 14 stream sites in the Milwaukee area, Wisconsin, 2004-13. 
Falls, Root River at Greenfield, Root River near Franklin, and Jewel Creek) (fig. 4). Although there were no differences greater than 10 percent in the relative abundance of freshwater diatoms at any site between 2004 and 2013, there were decreases of 10 percent or more in the abundance of halobiontic diatoms (having a tolerance or requirements for dissolved salts) between 2004 and 2013 at four sites: Lincoln Creek (26.3), Menomonee River at Menomonee Falls (10.2), Little Menomonee River (29.0), and Oak Creek (26.3). There were significant increases at four sites: Underwood Creek (27.8), Honey Creek (12.0), Menomonee River at Wauwatosa (18.5), Kinnickinnic River (20.6) (table 2, fig. 3B). The abundance of salt-tolerant diatoms would be expected to increase with increasing chloride and salinity in streams, and the relation will be discussed later in this report. This diatom metric could serve as a useful indicator of where road salt runoff is affecting urban streams.

\section{Invertebrates}

Invertebrate assemblages were evaluated using relative abundance as represented in MDS plots and metrics for taxa richness, percentage of taxa or individuals in certain functional groups such as the EPT, the Shannon index of diversity, the HBI-10, and the mIBI (table 4). A total of 305 invertebrate taxa were collected across all sites in the 4 sampling efforts. The number of taxa per site ranged from 13 taxa detected at the Little Menomonee River in Milwaukee site in 2010 to 46 at the Milwaukee River at Milwaukee site in fall 2004 (table 5). On average, there were about 25 taxa per site in the 2004-13 samples (excluding additional temporal samples).

In general, the MDS plot for invertebrates indicated that the assemblages within most sites remained relatively similar across sampling years, as demonstrated by points for each site grouping close together (fig. 5). Exceptions were seen for the Little Menomonee River site in all years, which seemed to have less stable assemblages across time, and for the Honey Creek site in 2004. For sites with additional temporal sampling in 2011-13, the MDS results indicated a high degree of similarity within each site, demonstrated by most samples grouping tightly and spring and fall samples generally grouping together also. However, the fall 2011 sample for the Lincoln Creek site was anomalous and grouped away from the rest of the site's samples. At the Milwaukee River near Cedarburg site in 2013, the spring sample grouped away from the rest of the samples for this site. Otherwise, invertebrate samples for this site were stable and similar from 2004 to 2013. The assemblages for the two main-stem Milwaukee River sites (Milwaukee River near Cedarburg and Milwaukee River at Milwaukee) grouped together and away from the other 12 sites, possibly because of the general nature of large river sites that often have higher productivity, more diverse habitat, and higher recolonization potential when compared with smaller streams. Samples for the Willow Creek site formed a distinct grouping away from all other sites, and this probably reflects the wetland nature of this small tributary and that invertebrates from this site only were collected from woody snags and not rocks. Overall, there was no larger pattern of site differences for 2010 when compared with later years, as was observed with the algal MDS results.

From 2004 to 2013, most sites had lower richness as demonstrated by fewer species and (or) genera-only three sites had more - and almost all sites had lower Shannon index of diversity values in 2013. The decreases in richness were all substantial (greater than 10 percent). The median number of taxa was lower in 2013 (20.5 taxa per site) compared with 2004 (28 taxa per site). In the four sampling efforts, the highest taxa richness for species was detected in 2004 at the two Milwaukee main-stem sites (Milwaukee River near Cedarburg and Milwaukee River at Milwaukee) with 45 and 46 species, respectively (table 5, fig. 6A). In fall 2013, the most taxa were detected at the Milwaukee River at Milwaukee site, and the fewest were detected at the Lincoln Creek and Honey Creek sites. However, the Menomonee River at Menomonee Falls, Underwood Creek, Oak Creek, and Jewel Creek sites ranked similarly low for richness in fall 2013. These findings indicate that the water quality and overall condition at these latter six sites in 2013 are more degraded than at other sampled sites.

The percentage of noninsect metric is a useful but complicated metric in that one needs to examine which taxa compose the noninsect metric in a sample. Native freshwater mussels contribute to the noninsect count but are indicative of good water quality. In general, the Milwaukee main-stem sites (Milwaukee River near Cedarburg and Milwaukee River at Milwaukee) had the lowest values for percentage of noninsects across all sampling years, except for a somewhat higher value in spring of 2013 at the Milwaukee River near Cedarburg site because of the presence of native freshwater mussels in the sample (table 5). The percentage of noninsects was also low at the Menomonee River at Wauwatosa, Kinnickinnic River, Oak Creek, Root River near Franklin, and Jewel Creek sites. The highest percentage of noninsects in 2013 was detected at the Root River at Greenfield, which also had high percentages in all sampling years relative to other sampled sites. The percentages of noninsects were relatively similar at most sites in 2004 and 2013; however, the percentages at three sites were more than 10 percent higher in 2013; values were more than 10 percent higher in 2013 at Willow Creek and the Little Menomonee River, indicating degraded water quality at these two sites.

Percentages of EPT taxa at most sites seemed relatively similar between 2004 and 2013; however, there were four sites where EPT taxa were more than 10 percent higher in 2013 (table 5, fig. 6). Although higher percentages of EPT taxa are good generally, some taxa are tolerant (mayfly and caddisfly taxa). For example, higher percentages at Honey Creek included taxa known to be relatively pollution tolerant (mayfly taxa Baetis flavistriga and Baetis intercalaris with caddisfly taxa Hydropsyche betteni and Cheumatopsyche; Barbour and others [1999]), and relative abundances of the two tolerant caddisfly taxa were higher in 2013 compared with 2004 (more than 28 percent and about 5 percent or less, respectively). At 
Table 4. Water-quality ratings for the invertebrate Hilsenhoff Biotic Index and macroinvertebrate Index of Biotic Integrity for streams.

[HBI, Hilsenhoff Biotic Index (Hilsenhoff, 1987); HBI-10, HBI modified to limit the number of individuals per taxon to 10 for index computation (Hilsenhoff, 1998); mIBI, macroinvertebrate Index of Biotic Integrity (Weigel, 2003); $\leq$, less than or equal to; >, greater than; NA, not applicable; $<$, less than]

\begin{tabular}{ccc}
\hline HBI/HBI-10 value & Water-quality rating & mIBI value \\
\hline$\leq 3.50$ & Excellent & $>8$ \\
$3.51-4.50$ & Very good & $\mathrm{NA}$ \\
$4.51-5.50$ & Good & $6-8$ \\
$5.51-6.50$ & Fair & $4-6$ \\
$6.51-7.50$ & Fairly poor & $\mathrm{NA}$ \\
$7.51-8.50$ & Poor & $2-4$ \\
$8.51-10.00$ & Very poor & $<2$ \\
\hline
\end{tabular}

the Kinnickinnic River site, the tolerant mayfly $B$. intercalaris was higher in 2013 compared with 2004 (29 percent and 5 percent, respectively). Tolerant EPT taxa were also common at other sampled sites. The highest percentages of EPT taxa in samples collected in 2013 were from the Milwaukee River near Cedarburg, Milwaukee River at Milwaukee, and the Menomonee River at Menomonee Falls site. Excluding spring temporal samples, the invertebrate assemblages at the Root River at Greenfield site had the lowest percentage of EPT taxa (13) but the Willow Creek, Little Menomonee River, Underwood Creek, Menomonee River at Wauwatosa, and Kinnickinnic River sites were similarly low with only 18-21 percent EPT taxa (table 5). Willow Creek is a sandy bottom stream with no riffles, and therefore, the low numbers of EPT taxa are not unexpected. Plecoptera (stoneflies), which require fast flowing waters with high oxygen content and riffles, were not detected at any of the sampling locations.

In many cases, ratings for the invertebrate mIBI indicated more degraded water quality than did ratings for the HBI-10 (table 5, fig. 6B). HBI-10 scores for 2013 invertebrate samples ranged from results indicating "fairly poor" water quality at four sites (Lincoln Creek, Underwood Creek, Kinnickinnic River, and Root River at Greenfield) to "good" water quality at the two Milwaukee River main-stem sites, Menomonee River at Menomonee Falls, Honey Creek, and Jewel Creek; five sites had scores indicating "fair" water quality (Willow Creek, Little Menomonee River, Menomonee River at Wauwatosa, Oak Creek, and Root River near Franklin). A "fairly poor" rating for the HBI-10 would be a "poor" rating in the IBI. The mIBI scores for 2013 ranged from values indicating "very poor" at one site (Kinnickinnic River) to "fair" at the two Milwaukee main-stem sites (Milwaukee River near Cedarburg and Milwaukee River at Milwaukee) and three other sites; the other seven sites were rated "poor." HBI-10 scores were more than 10 percent higher (indicating a worse rating) at only two sites, whereas mIBI scores were more than 10 percent lower (also indicating a worse rating) at six sites. The largest differences (more than two ranks) between HBI-10 and mIBI ratings were for Lincoln Creek in 2010, when HBI-10 ratings indicated "fair" and mIBI ratings indicated "very poor," and for Honey Creek in 2004, 2010, and 2013 and Jewel Creek in 2013 when HBI-10 ratings indicated "good" and mIBI ratings indicated "poor." The reason for the difference in ratings between these two metrics is unclear but it could perhaps be due to the fact that the HBI-10 does not weight the percentage of EPT taxa and the mIBI does. For invertebrate metrics computed at the three temporal sites, the smallest coefficient of variation was determined for the HBI-10 (less than 8.3 percent for spring samples and less than 5.3 percent for fall samples), indicating the consistency/stability of this metric for site assessments and comparisons to other sites (table 5). When 2004 and 2013 data are compared for all 14 sites, results across invertebrate metrics were not consistent for a given site (table 5); however, invertebrate metrics for most sites in 2013 were lower than in 2004 and indicate that water quality for invertebrates at most sampled sites was more degraded in 2013. This finding was especially evident for the Lincoln Creek, Underwood Creek, and Root River at Greenfield sites (fig. 7). Possible reasons for the degradation with respect to each sampled site are discussed in more detail later in this report.

\section{Fish}

Fish assemblages were evaluated using relative abundance, as represented in MDS plots, and metrics for taxa richness, percentage of individuals in certain functional groups, Shannon index of diversity, and IBI (table 6). A total of 45 fish taxa (not including hybrids) were collected across all sites in the four sampling efforts, and individual year totals ranged from 32 to 37 . The number of taxa per site ranged from no fish detected at the Kinnickinnic River site in 2013 to 22 at the Milwaukee River near Cedarburg site in 2010 (table 7). On average, there were more than 9 species per site in the 2004-13 samples, with a mean of 231 individual fish. At more than half of the sites, the number of fish collected was substantially lower (greater than or equal to $[\geq] 47$ percent) in 2013 than in 2004; however, the number of fish collected was substantially higher ( $\geq 86$ percent) at three sites and relatively unchanged at two sites. The lower numbers of fish collected were at times in contrast with positive differences in other metrics at many sites.

Similar to the MDS plot for invertebrates, the MDS plot for fish indicated that assemblages at most sites were relatively similar across years, as demonstrated by values for each site grouping fairly closely together (fig. 8). However, the Little Menomonee River site fish assemblages demonstrated the most variability across years while remaining similar to the larger group of small rivers and creeks on the left side of the plot, as was also seen for invertebrates. The fish assemblage for the Willow Creek site demonstrated relatively high variability across sampling years as well and especially in 2007, 
Table 5. Comparison of invertebrate-assemblage data at 14 stream sites in the Milwaukee Metropolitan Sewerage District planning area, Wisconsin, $2004-13$.

[The percentage of differences in metric values between fall 2013 and fall 2004 is shown (Difference), and percentages greater than 10 percent are highlighted; yellow denotes a potentially adverse difference, and blue denotes a potentially beneficial difference. The coefficient of variation (CV) is provided for comparing data for 2011-13 at temporal sampling sites; EPT, Ephemeroptera, Plecoptera, Trichoptera;

HBI-10, HBI modified to limit the number of individuals per taxon to 10 for index computation; mIBI, macroinvertebrate Index of Biotic Integrity; USGS, U.S. Geological Survey; SP, spring; FL, fall; NC, not characterized]

\begin{tabular}{|c|c|c|c|c|c|c|c|c|c|}
\hline \multirow{2}{*}{ Collection year } & \multirow{2}{*}{$\begin{array}{l}\text { Number of } \\
\text { species }\end{array}$} & \multirow{2}{*}{$\begin{array}{l}\text { Number of } \\
\text { genera }\end{array}$} & \multirow{2}{*}{$\begin{array}{l}\text { Percentage of } \\
\text { noninsects }\end{array}$} & \multirow{2}{*}{$\begin{array}{l}\text { Percentage of } \\
\text { EPT taxa }\end{array}$} & \multirow{2}{*}{$\begin{array}{l}\text { Shannon index of } \\
\text { diversity }{ }^{1}\end{array}$} & \multicolumn{2}{|c|}{$\mathrm{HBI}-10^{2}$} & \multicolumn{2}{|c|}{$\left.\mathrm{mIB}\right|^{3}$} \\
\hline & & & & & & Score & Rating & Score & Rating \\
\hline \multicolumn{10}{|c|}{ Milwaukee River near Cedarburg (USGS station 04086600) } \\
\hline 2004 & 45 & 39 & 0.77 & 51 & 3.86 & 5.01 & Good & 7.59 & Good \\
\hline 2007 & 26 & 23 & 0.00 & 48 & 3.55 & 4.79 & Good & 6.25 & Good \\
\hline 2010 & 36 & 31 & 0.41 & 48 & 3.94 & 4.71 & Good & 5.06 & Fair \\
\hline 2011, SP & 43 & 37 & 0.48 & 43 & 3.90 & 5.44 & Good & 7.94 & Good \\
\hline 2011, FL & 30 & 25 & 1.83 & 60 & 3.48 & 4.83 & Good & 7.61 & Good \\
\hline $2012, \mathrm{SP}$ & 40 & 33 & 0.51 & 52 & 4.10 & 5.16 & Good & 9.13 & Excellent \\
\hline 2012, FL & 39 & 33 & 0.41 & 36 & 3.54 & 5.15 & Good & 3.73 & Poor \\
\hline 2013, SP & 37 & 28 & 11.7 & 29 & 2.41 & 5.60 & Fair & 5.02 & Fair \\
\hline 2013, FL & 25 & 22 & 2.06 & 50 & 2.41 & 4.91 & Good & 5.94 & Fair \\
\hline Difference & -44 & -44 & 1.3 & -1.0 & -37.6 & -2.06 & No difference & -21.7 & Lower \\
\hline $\mathrm{CV}, \mathrm{SP}$ & 7.5 & 14 & 150 & 28 & 26.7 & 4.15 & $\mathrm{NC}$ & 28.7 & $\mathrm{NC}$ \\
\hline CV, FL & 23 & 21 & 62 & 25 & 20.2 & 3.36 & NC & 33.8 & NC \\
\hline \multicolumn{10}{|c|}{ Lincoln Creek at 47th Street at Milwaukee (USGS station 040869415) } \\
\hline 2004 & 20 & 17 & 34.2 & 18 & 3.06 & 6.30 & Fair & 3.06 & Poor \\
\hline 2007 & 32 & 24 & 7.35 & 21 & 2.60 & 6.46 & Fair & 3.78 & Poor \\
\hline 2010 & 31 & 27 & 20.1 & 19 & 2.50 & 6.41 & Fair & 1.17 & Very poor \\
\hline 2011, SP & 14 & 11 & 30.7 & 27 & 1.06 & 6.93 & Fairly poor & 3.18 & Poor \\
\hline 2011, FL & 20 & 20 & 29.1 & 14 & 3.23 & 6.22 & Fair & 2.49 & Poor \\
\hline 2012, SP & 12 & 10 & 48.5 & 10 & 2.53 & 7.09 & Fairly poor & 1.20 & Very poor \\
\hline 2012, FL & 29 & 25 & 7.00 & 16 & 2.93 & 6.67 & Fairly poor & 3.49 & Poor \\
\hline 2013, SP & 25 & 18 & 14.4 & 11 & 1.54 & 7.10 & Fairly poor & 3.39 & Poor \\
\hline 2013, FL & 14 & 14 & 29.6 & 29 & 1.96 & 6.89 & Fairly poor & 2.54 & Poor \\
\hline Difference & -30 & -18 & -4.63 & 11 & -36.0 & 9.43 & Lower & -16.9 & No difference \\
\hline $\mathrm{CV}, \mathrm{SP}$ & 41 & 34 & 54.7 & 60 & 44.1 & 1.37 & $\mathrm{NC}$ & 46.6 & $\mathrm{NC}$ \\
\hline CV, FL & 36 & 28 & 58.9 & 41 & 24.6 & 5.20 & $\mathrm{NC}$ & 19.8 & NC \\
\hline
\end{tabular}


Table 5. Comparison of invertebrate-assemblage data at 14 stream sites in the Milwaukee Metropolitan Sewerage District planning area, Wisconsin, 2004-13.-Continued

[The percentage of differences in metric values between fall 2013 and fall 2004 is shown (Difference), and percentages greater than 10 percent are highlighted; yellow denotes a potentially adverse difference, and blue denotes a potentially beneficial difference. The coefficient of variation (CV) is provided for comparing data for 2011-13 at temporal sampling sites; EPT, Ephemeroptera, Plecoptera, Trichoptera;

HBI-10, HBI modified to limit the number of individuals per taxon to 10 for index computation; mIBI, macroinvertebrate Index of Biotic Integrity; USGS, U.S. Geological Survey; SP, spring; FL, fall; NC, not characterized]

\begin{tabular}{|c|c|c|c|c|c|c|c|c|c|}
\hline \multirow{2}{*}{ Collection year } & \multirow{2}{*}{$\begin{array}{l}\text { Number of } \\
\text { species }\end{array}$} & \multirow{2}{*}{$\begin{array}{c}\text { Number of } \\
\text { genera }\end{array}$} & \multirow{2}{*}{$\begin{array}{l}\text { Percentage of } \\
\text { noninsects }\end{array}$} & \multirow{2}{*}{$\begin{array}{l}\text { Percentage of } \\
\text { EPT taxa }\end{array}$} & \multirow{2}{*}{$\begin{array}{l}\text { Shannon index of } \\
\text { diversity }{ }^{1}\end{array}$} & \multicolumn{2}{|c|}{$\mathrm{HBI}-10^{2}$} & \multicolumn{2}{|c|}{$\mathrm{mIB|3}$} \\
\hline & & & & & & Score & Rating & Score & Rating \\
\hline \multicolumn{10}{|c|}{ Milwaukee River at Milwaukee (USGS station 04087000) } \\
\hline 2004 & 46 & 41 & 0.94 & 39 & 3.70 & 5.20 & Good & 6.39 & Good \\
\hline 2007 & 42 & 36 & 8.02 & 39 & 4.14 & 5.52 & Fair & 7.94 & Good \\
\hline 2010 & 35 & 32 & 1.23 & 50 & 3.43 & 4.45 & Very good & 6.33 & Good \\
\hline 2013 & 29 & 26 & 1.03 & 38 & 1.94 & 5.31 & Good & 5.43 & Fair \\
\hline Difference & -37 & -37 & 0.086 & -1.0 & -47.6 & 2.10 & No difference & -15.0 & Lower \\
\hline \multicolumn{10}{|c|}{ Willow Creek at Maple Road, near Germantown (USGS station 040870195) } \\
\hline 2004 & 32 & 29 & 12.2 & 17 & 3.94 & 5.45 & Good & 3.87 & Poor \\
\hline 2007 & 33 & 29 & 19.9 & 21 & 3.94 & 5.61 & Fair & 4.99 & Fair \\
\hline 2010 & 26 & 25 & 9.09 & 20 & 3.84 & 5.51 & Fair & 3.82 & Poor \\
\hline 2013 & 26 & 25 & 43.6 & 20 & 2.54 & 5.66 & Fair & 3.68 & Poor \\
\hline Difference & -19 & -14 & 31.4 & 3.0 & -35.5 & 3.91 & Lower & -4.73 & No difference \\
\hline \multicolumn{10}{|c|}{ Menomonee River at Menomonee Falls (USGS station 04087030) } \\
\hline 2004 & 18 & 16 & 8.29 & 44 & 2.29 & 5.56 & Fair & 4.75 & Fair \\
\hline 2007 & 24 & 22 & 2.93 & 32 & 3.27 & 4.77 & Good & 3.91 & Poor \\
\hline 2010 & 18 & 15 & 1.56 & 33 & 2.69 & 5.79 & Fair & 3.75 & Poor \\
\hline 2011, SP & 19 & 16 & 27.1 & 25 & 3.03 & 5.75 & Fair & 2.73 & Poor \\
\hline 2011, FL & 16 & 15 & 2.35 & 40 & 2.05 & 5.54 & Fair & 3.03 & Poor \\
\hline $2012, \mathrm{SP}$ & 18 & 17 & 10.7 & 41 & 2.79 & 4.94 & Good & 3.37 & Poor \\
\hline $2012, \mathrm{FL}$ & 23 & 22 & 4.37 & 32 & 3.21 & 5.17 & Good & 3.14 & Poor \\
\hline $2013, \mathrm{SP}$ & 23 & 21 & 3.14 & 19 & 2.03 & 5.69 & Fair & 2.61 & Poor \\
\hline 2013, FL & 15 & 14 & 9.57 & 50 & 1.96 & 5.05 & Good & 5.82 & Fair \\
\hline Difference & -17 & -12 & 1.28 & 6.0 & -14.2 & -9.21 & Higher & 22.5 & No difference \\
\hline CV, SP & 13 & 15 & 89.6 & 40 & 20.0 & 8.26 & NC & 14.1 & NC \\
\hline CV, FL & 24 & 26 & 68.6 & 22 & 28.9 & 4.92 & NC & 39.5 & $\mathrm{NC}$ \\
\hline
\end{tabular}


[The percentage of differences in metric values between fall 2013 and fall 2004 is shown (Difference), and percentages greater than 10 percent are highlighted; yellow denotes a potentially adverse difference, and blue denotes a potentially beneficial difference. The coefficient of variation (CV) is provided for comparing data for 2011-13 at temporal sampling sites; EPT, Ephemeroptera, Plecoptera, Trichoptera;

HBI-10, HBI modified to limit the number of individuals per taxon to 10 for index computation; mIBI, macroinvertebrate Index of Biotic Integrity; USGS, U.S. Geological Survey; SP, spring; FL, fall; NC, not characterized]

\begin{tabular}{|c|c|c|c|c|c|c|c|c|c|}
\hline \multirow{2}{*}{ Collection year } & \multirow{2}{*}{$\begin{array}{l}\text { Number of } \\
\text { species }\end{array}$} & \multirow{2}{*}{$\begin{array}{c}\text { Number of } \\
\text { genera }\end{array}$} & \multirow{2}{*}{$\begin{array}{l}\text { Percentage of } \\
\text { noninsects }\end{array}$} & \multirow{2}{*}{$\begin{array}{l}\text { Percentage of } \\
\text { EPT taxa }\end{array}$} & \multirow{2}{*}{$\begin{array}{c}\text { Shannon index of } \\
\text { diversity }{ }^{1}\end{array}$} & \multicolumn{2}{|c|}{$\mathrm{HBI}-102$} & \multicolumn{2}{|c|}{$\mathrm{mIB|3}$} \\
\hline & & & & & & Score & Rating & Score & Rating \\
\hline \multicolumn{10}{|c|}{ Little Menomonee River at Milwaukee (USGS station 04087070) } \\
\hline 2004 & 23 & 22 & 36.5 & 23 & 2.28 & 5.33 & Good & 3.32 & Poor \\
\hline 2007 & 22 & 18 & 60.3 & 17 & 2.58 & 6.57 & Fairly poor & 3.44 & Poor \\
\hline 2010 & 13 & 12 & 7.86 & 42 & 1.34 & 5.96 & Fair & 2.55 & Poor \\
\hline 2013 & 28 & 23 & 54.0 & 21 & 1.98 & 5.96 & Fair & 4.31 & Fair \\
\hline Difference & 22 & 4.5 & 17.5 & $-\mathbf{2 . 0}$ & -13.1 & 11.8 & Lower & 29.7 & Higher \\
\hline \multicolumn{10}{|c|}{ Underwood Creek at Wauwatosa (USGS station 04087088) } \\
\hline 2004 & 33 & 28 & 3.56 & 18 & 2.71 & 5.96 & Fair & 2.72 & Poor \\
\hline 2007 & 21 & 17 & 29.9 & 12 & 2.64 & 6.66 & Fairly poor & 3.78 & Poor \\
\hline 2010 & 24 & 20 & 5.41 & 25 & 3.16 & 6.74 & Fairly poor & 3.84 & Poor \\
\hline 2013 & 17 & 15 & 12.3 & 20 & 1.61 & 7.14 & Fairly poor & 3.32 & Poor \\
\hline Difference & -48 & -46 & 8.78 & 2.0 & -40.5 & 19.8 & Lower & 22.0 & No difference \\
\hline \multicolumn{10}{|c|}{ Honey Creek at Wauwatosa (USGS station 04087119) } \\
\hline 2004 & 24 & 24 & 49.0 & 17 & 2.73 & 5.28 & Good & 3.39 & Poor \\
\hline 2007 & 17 & 14 & 7.28 & 36 & 2.96 & 5.81 & Fair & 4.12 & Fair \\
\hline 2010 & 23 & 19 & 13.7 & 26 & 2.57 & 5.48 & Good & 2.93 & Poor \\
\hline 2013 & 14 & 13 & 5.12 & 31 & 1.55 & 5.49 & Good & 2.12 & Poor \\
\hline Difference & -42 & -46 & -43.9 & 14 & -43.1 & 4.00 & No difference & -37.3 & No difference \\
\hline \multicolumn{10}{|c|}{ Menomonee River at Wauwatosa (USGS station 04087120) } \\
\hline 2004 & 20 & 16 & 2.39 & 31 & 2.68 & 5.86 & Fair & 3.41 & Poor \\
\hline 2007 & 22 & 17 & 5.56 & 29 & 2.21 & 5.85 & Fair & 4.54 & Fair \\
\hline 2010 & 22 & 19 & 2.04 & 26 & 3.10 & 6.22 & Fair & 2.83 & Poor \\
\hline 2013 & 24 & 19 & 3.60 & 21 & 1.98 & 6.26 & Fair & 2.67 & Poor \\
\hline Difference & 20 & 19 & 1.21 & -10 & -26.4 & 6.76 & No difference & -21.6 & No difference \\
\hline \multicolumn{10}{|c|}{ Kinnickinnic River at South 11th Street at Milwaukee (USGS station 04087159) } \\
\hline 2004 & 34 & 27 & 22.5 & 7.0 & 3.02 & 6.52 & Fairly poor & 3.17 & Poor \\
\hline 2007 & 21 & 16 & 7.25 & 31 & 2.04 & 6.09 & Fair & 4.13 & Fair \\
\hline 2010 & 17 & 13 & 3.65 & 23 & 2.48 & 6.47 & Fair & 2.44 & Poor \\
\hline 2013 & 18 & 11 & 1.20 & 18 & 1.06 & 6.55 & Fairly poor & 1.58 & Very poor \\
\hline Difference & -47 & -59 & -21.3 & 11 & -64.8 & 0.491 & No difference & $-\mathbf{5 0 . 0}$ & Lower \\
\hline
\end{tabular}


Table 5. Comparison of invertebrate-assemblage data at 14 stream sites in the Milwaukee Metropolitan Sewerage District planning area, Wisconsin, 2004-13.-Continued

[The percentage of differences in metric values between fall 2013 and fall 2004 is shown (Difference), and percentages greater than 10 percent are highlighted; yellow denotes a potentially adverse difference, and blue denotes a potentially beneficial difference. The coefficient of variation (CV) is provided for comparing data for 2011-13 at temporal sampling sites; EPT, Ephemeroptera, Plecoptera, Trichoptera;

HBI-10, HBI modified to limit the number of individuals per taxon to 10 for index computation; mIBI, macroinvertebrate Index of Biotic Integrity; USGS, U.S. Geological Survey; SP, spring; FL, fall; NC, not characterized]

\begin{tabular}{|c|c|c|c|c|c|c|c|c|c|}
\hline \multirow{2}{*}{ Collection year } & \multirow{2}{*}{$\begin{array}{l}\text { Number of } \\
\text { species }\end{array}$} & \multirow{2}{*}{$\begin{array}{c}\text { Number of } \\
\text { genera }\end{array}$} & \multirow{2}{*}{$\begin{array}{l}\text { Percentage of } \\
\text { noninsects }\end{array}$} & \multirow{2}{*}{$\begin{array}{l}\text { Percentage of } \\
\text { EPT taxa }\end{array}$} & \multirow{2}{*}{$\begin{array}{l}\text { Shannon index of } \\
\text { diversity }{ }^{1}\end{array}$} & \multicolumn{2}{|c|}{ HBI-102 } & \multicolumn{2}{|c|}{$\mathrm{mIB|3}$} \\
\hline & & & & & & Score & Rating & Score & Rating \\
\hline \multicolumn{10}{|c|}{ Oak Creek at South Milwaukee (USGS station 04087204) } \\
\hline 2004 & 28 & 23 & 5.94 & 22 & 2.86 & 5.55 & Fair & 2.80 & Poor \\
\hline 2007 & 32 & 26 & 21.7 & 19 & 3.61 & 5.77 & Fair & 4.34 & Fair \\
\hline 2010 & 24 & 19 & 2.30 & 32 & 2.62 & 5.82 & Fair & 2.65 & Poor \\
\hline 2013 & 16 & 14 & 1.45 & 36 & 1.48 & 5.56 & Fair & 3.07 & Poor \\
\hline Difference & -43 & -39 & -4.49 & 14 & -48.3 & 0.162 & No difference & 9.66 & No difference \\
\hline \multicolumn{10}{|c|}{ Root River at Grange Avenue at Greenfield (USGS station 04087214) } \\
\hline 2004 & 23 & 22 & 54.0 & 18 & 2.69 & 6.15 & Fair & 2.52 & Poor \\
\hline 2007 & 25 & 21 & 26.6 & 19 & 3.38 & 5.73 & Fair & 3.75 & Poor \\
\hline 2010 & 20 & 16 & 23.4 & 25 & 2.62 & 6.98 & Fairly poor & 3.17 & Poor \\
\hline 2013 & 23 & 16 & 59.0 & 13 & 1.78 & 6.63 & Fairly poor & 3.31 & Poor \\
\hline Difference & $\mathbf{0}$ & -27 & 5.00 & -5.0 & -33.6 & 7.85 & Lower & 31.2 & No difference \\
\hline \multicolumn{10}{|c|}{ Root River near Franklin (USGS station 04087220) } \\
\hline 2004 & 31 & 25 & 4.26 & 28 & 3.35 & 5.92 & Fair & 4.20 & Fair \\
\hline 2007 & 27 & 24 & 4.10 & 25 & 2.86 & 5.73 & Fair & 3.56 & Poor \\
\hline 2010 & 15 & 15 & 1.72 & 33 & 2.51 & 5.99 & Fair & 2.06 & Poor \\
\hline 2013 & 33 & 29 & 4.17 & 28 & 2.75 & 6.19 & Fair & 5.44 & Fair \\
\hline Difference & 6.4 & 16 & -0.09 & $\mathbf{0}$ & -17.8 & 4.53 & No difference & 29.6 & No difference \\
\hline \multicolumn{10}{|c|}{ Jewel Creek at Muskego (USGS station 05544371) } \\
\hline 2004 & 28 & 24 & 22.7 & 29 & 3.07 & 5.58 & Fair & 3.29 & Poor \\
\hline 2007 & 37 & 29 & 6.19 & 17 & 3.31 & 5.79 & Fair & 2.87 & Poor \\
\hline 2010 & 30 & 23 & 10.6 & 30 & 3.03 & 5.75 & Fair & 2.68 & Poor \\
\hline 2013 & 18 & 15 & 2.03 & 27 & 1.75 & 5.00 & Good & 3.39 & Poor \\
\hline Difference & -36 & -38 & -20.7 & -2.0 & -43.0 & -10.4 & Higher & 2.92 & No difference \\
\hline
\end{tabular}

${ }^{1}$ Shannon diversity, calculated as $\log _{\mathrm{e}}$ (Shannon, 1948).

2Hilsenhoff, 1987, 1998.

3Weigel, 2003. 


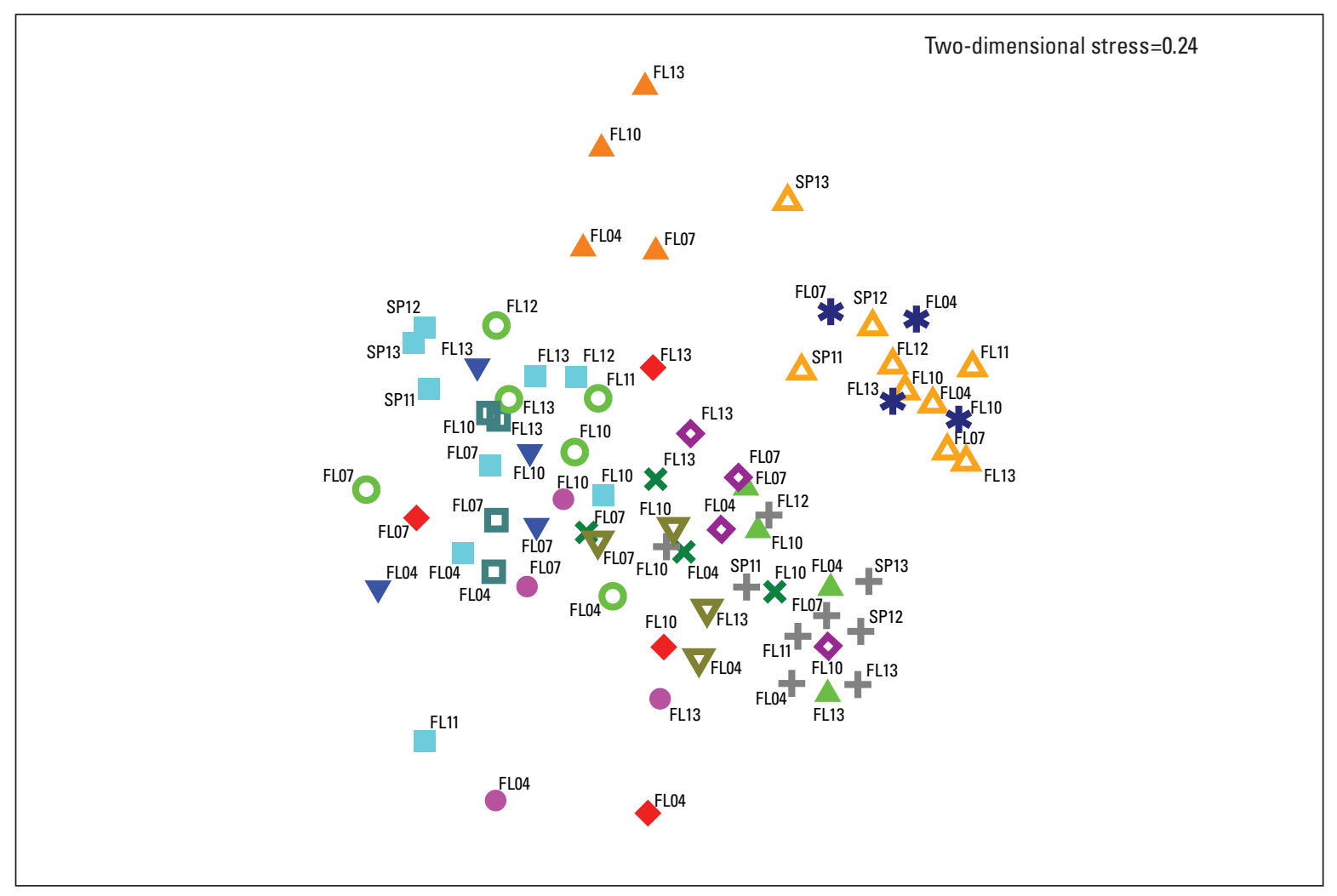

EXPLANATION

IMRC, Milwaukee River near Cedarburg; LCM, Lincoln M, Milwauke River at Milwaukee; WCG, Willow Creek at Maple Road, near Germantown; MRMF, Menomonee River at

Menomonee Falls; LMM, Little Menomonee River at Milwaukee; UCW, Underwood Creek at Wauwatosa; HCW, Honey Creek at Wauwatosa; MRW, Menomonee River at Wauwatosa; KRM, Kinnickinnic River at South 11th Street at Milwaukee; OCSM, Oak Creek at South Milwaukee; RRG, Root River at Grange Avenue at Greenfield; RRF, Root River near Franklin; JCM, Jewel Creek at Muskego; SP, spring samples; FL, fall samples

\section{Site abbreviation}
$\triangle$ MRC
- LCM
\% MRM
$\triangle$ WCG
+ MRMF
LMM
- UCW
- HCW
* MRW
KRM
$\nabla$ OCSM
प RRG
$\checkmark$ RRF
JCM

Figure 5. Multidimensional scaling ordination plot for invertebrate assemblages collected at 14 sites in the Milwaukee area, Wisconsin, 2004-13. [The sampling year is shown as $04,07,10$, and 13 for 2004, 2007, 2010, and 2013, respectively] 


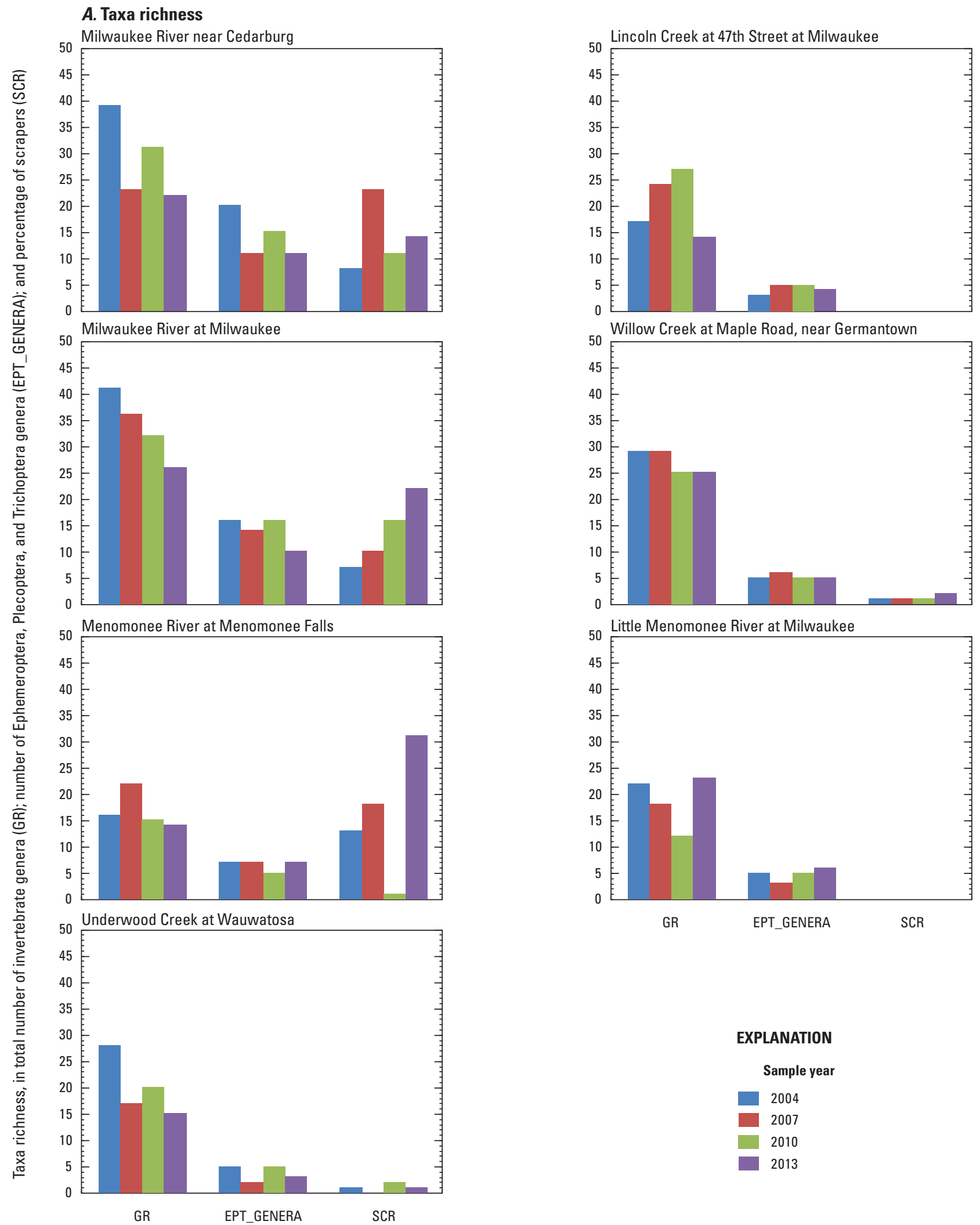

Figure 6. Selected invertebrate metrics for each of the 14 stream sites in the Milwaukee area, Wisconsin, 2004-13. A, taxa richness; $B$, ratings for indexes of biotic integrity and diversity. 


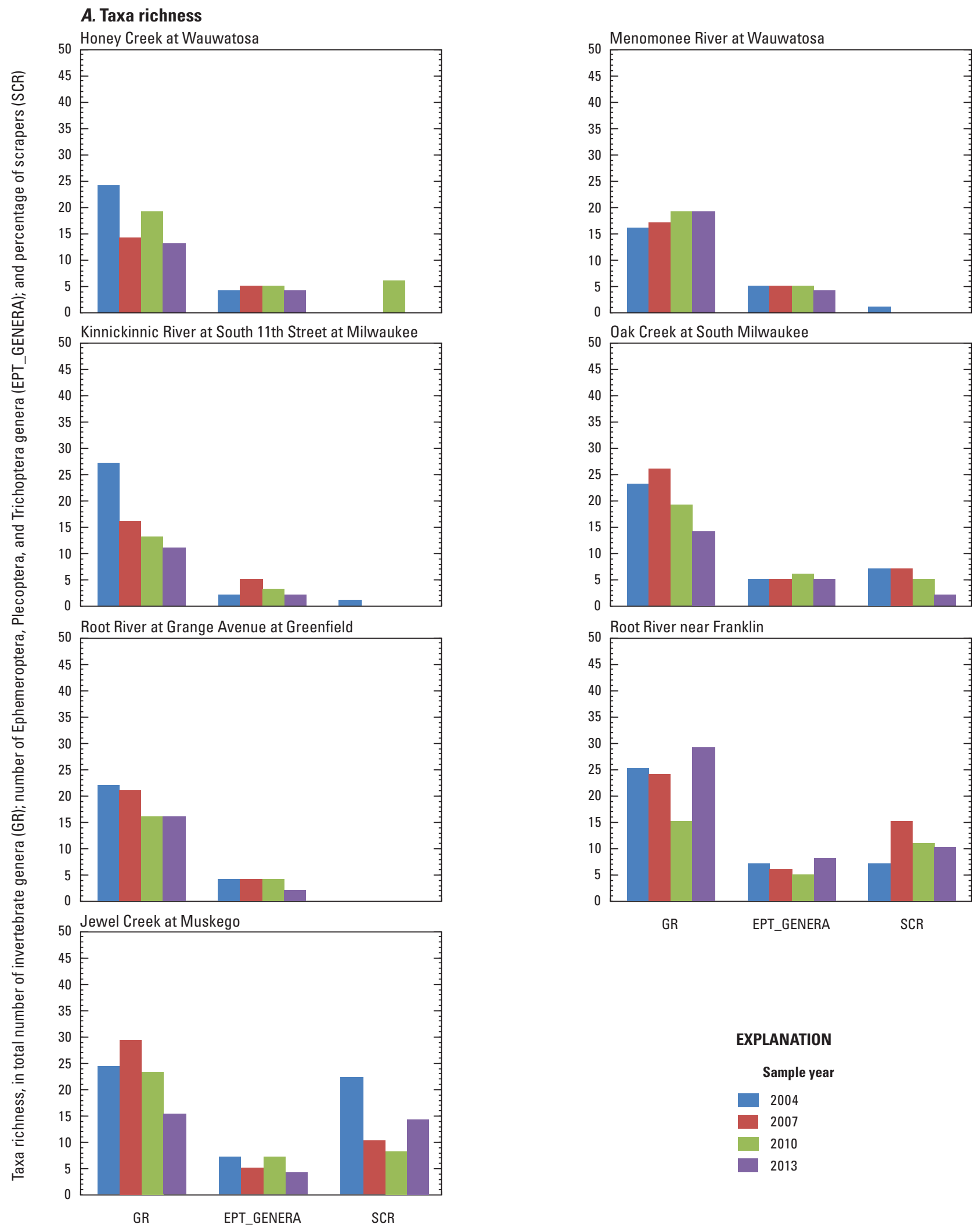

Figure 6. Selected invertebrate metrics for each of the 14 stream sites in the Milwaukee area, Wisconsin, 2004-13. A, taxa richness; $B$, ratings for indexes of biotic integrity and diversity.-Continued 
$B$. Values for indexes of biotic integrity and diversity

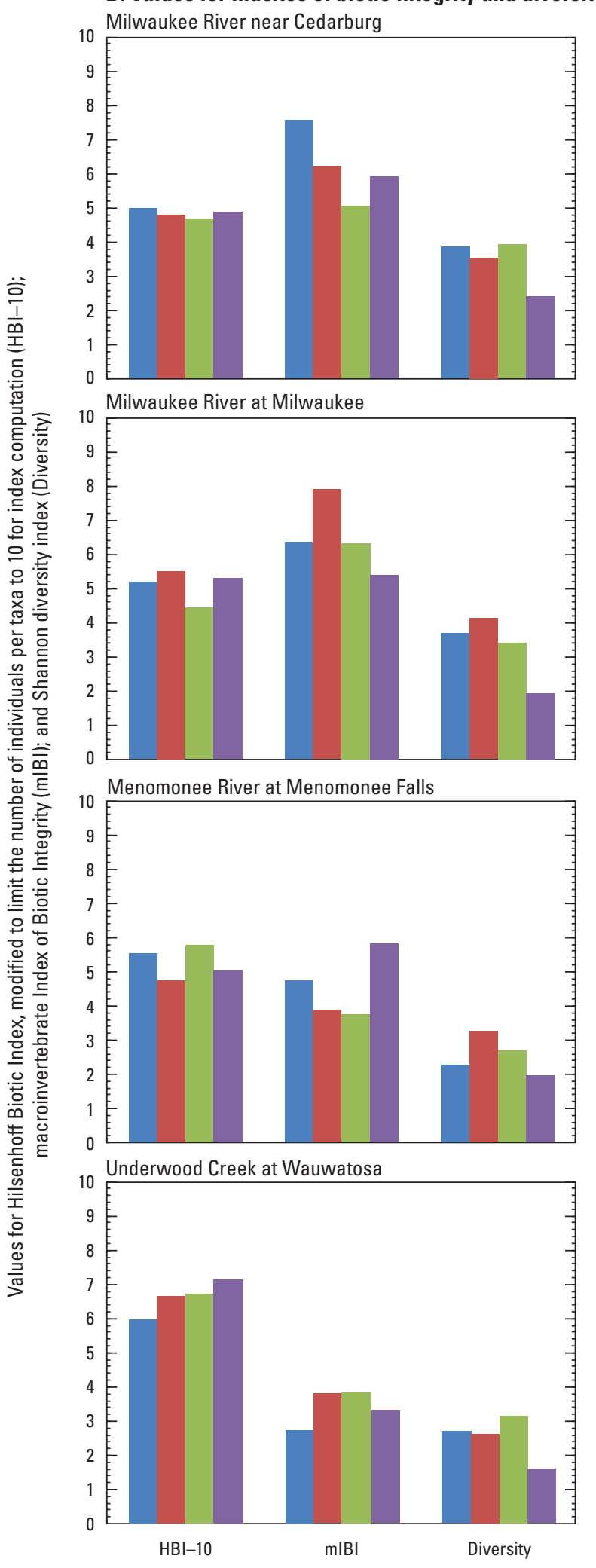

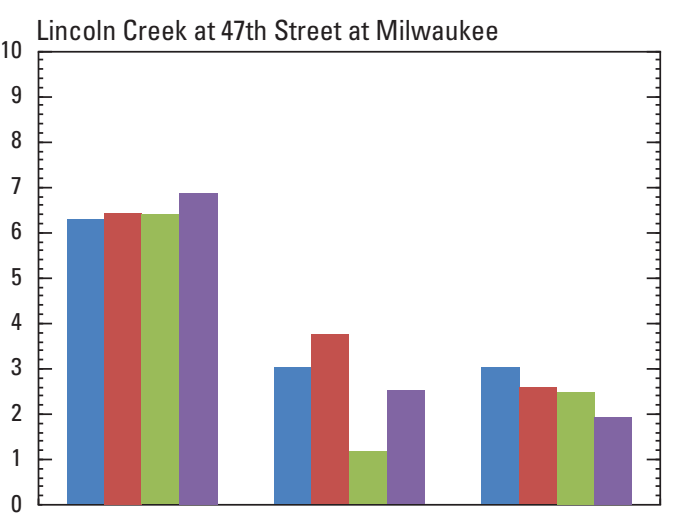
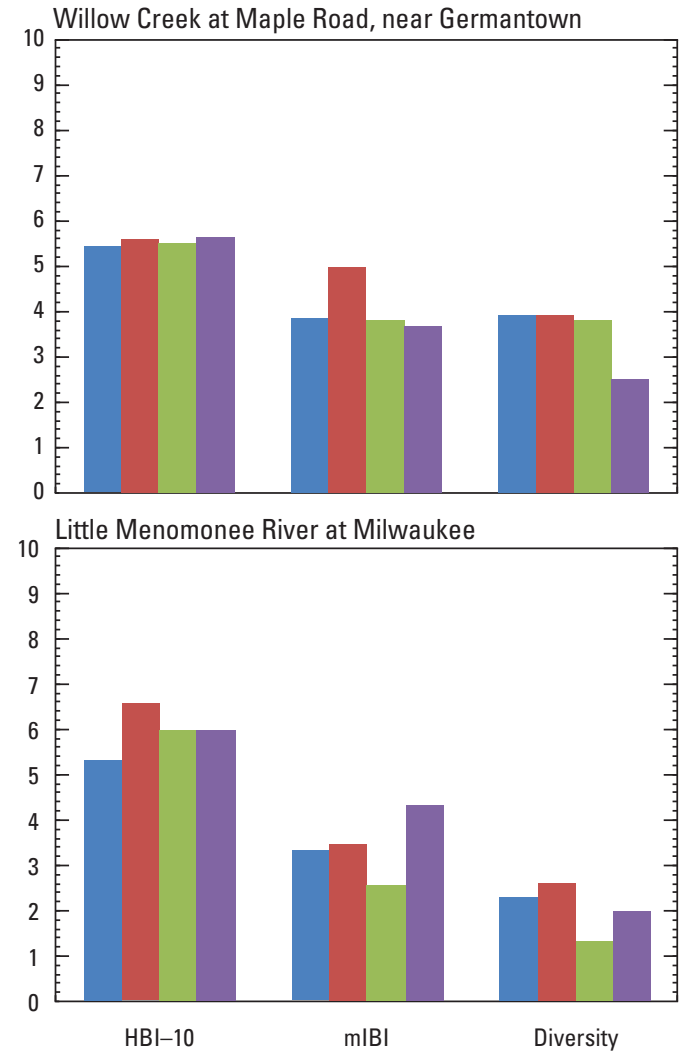

EXPLANATION
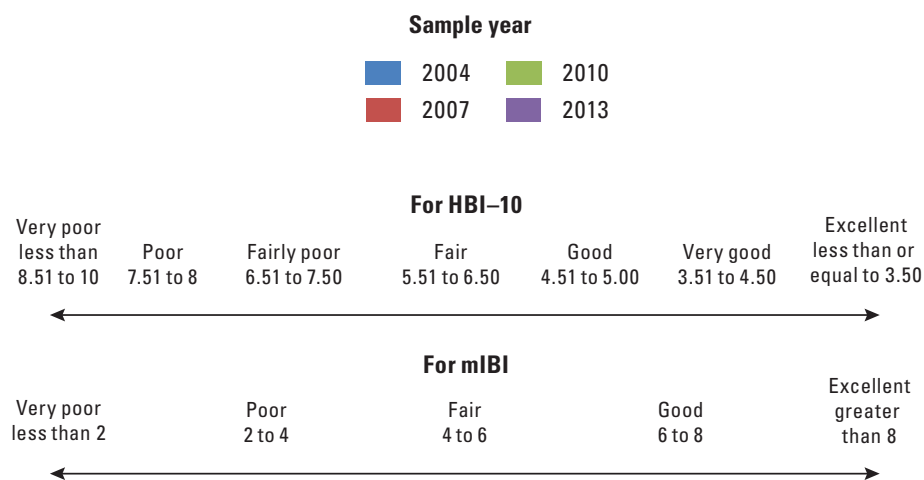

Figure 6. Selected invertebrate metrics for each of the 14 stream sites in the Milwaukee area, Wisconsin, 2004-13. A, taxa richness; $B$, ratings for indexes of biotic integrity and diversity.-Continued 

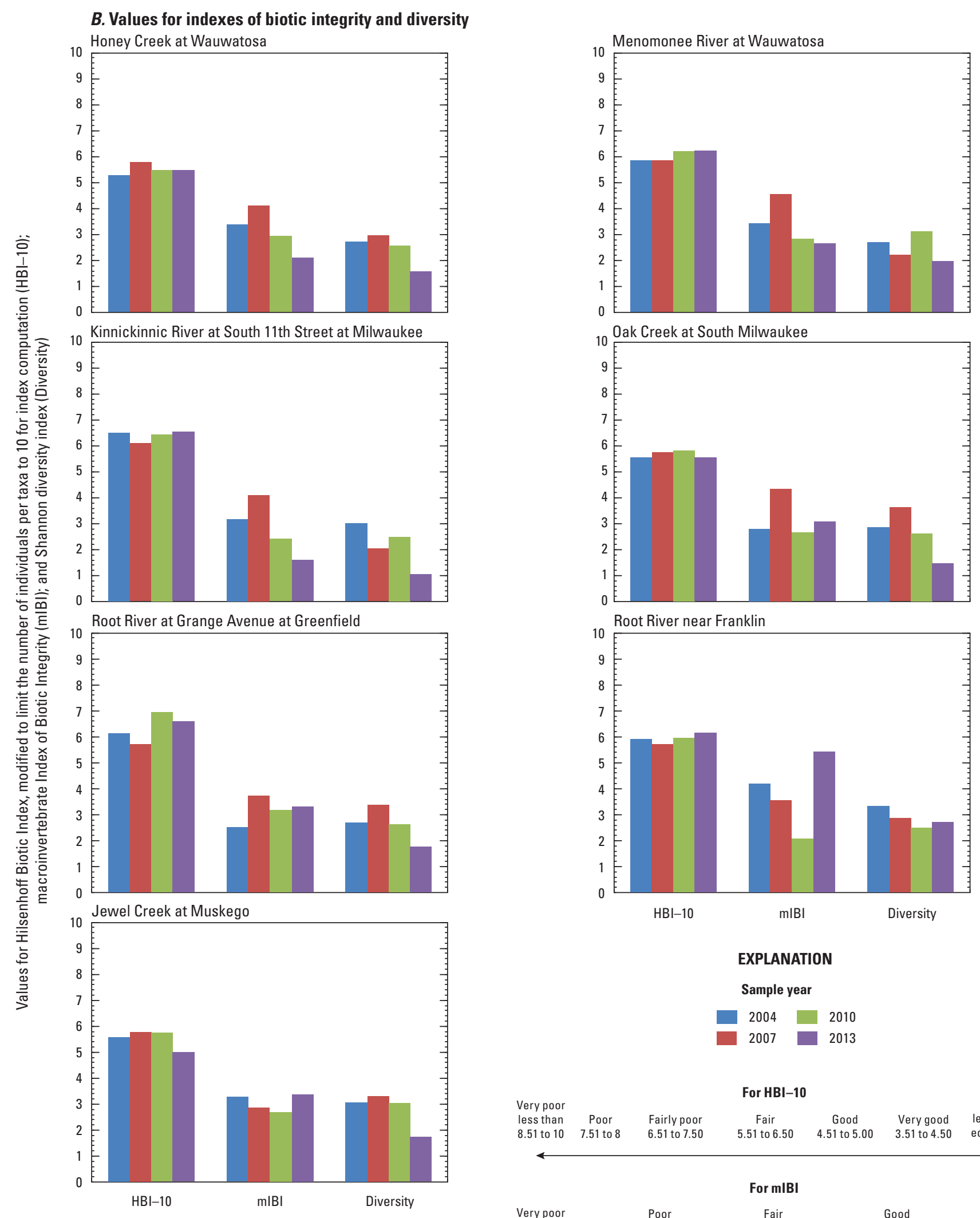

EXPLANATION
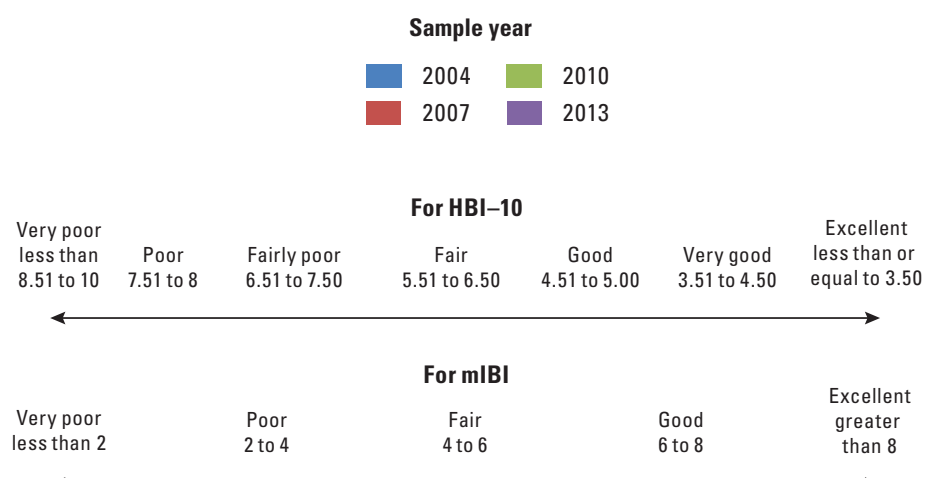

Figure 6. Selected invertebrate metrics for each of the 14 stream sites in the Milwaukee area, Wisconsin, 2004-13. A, taxa richness; $B$, ratings for indexes of biotic integrity and diversity.-Continued 


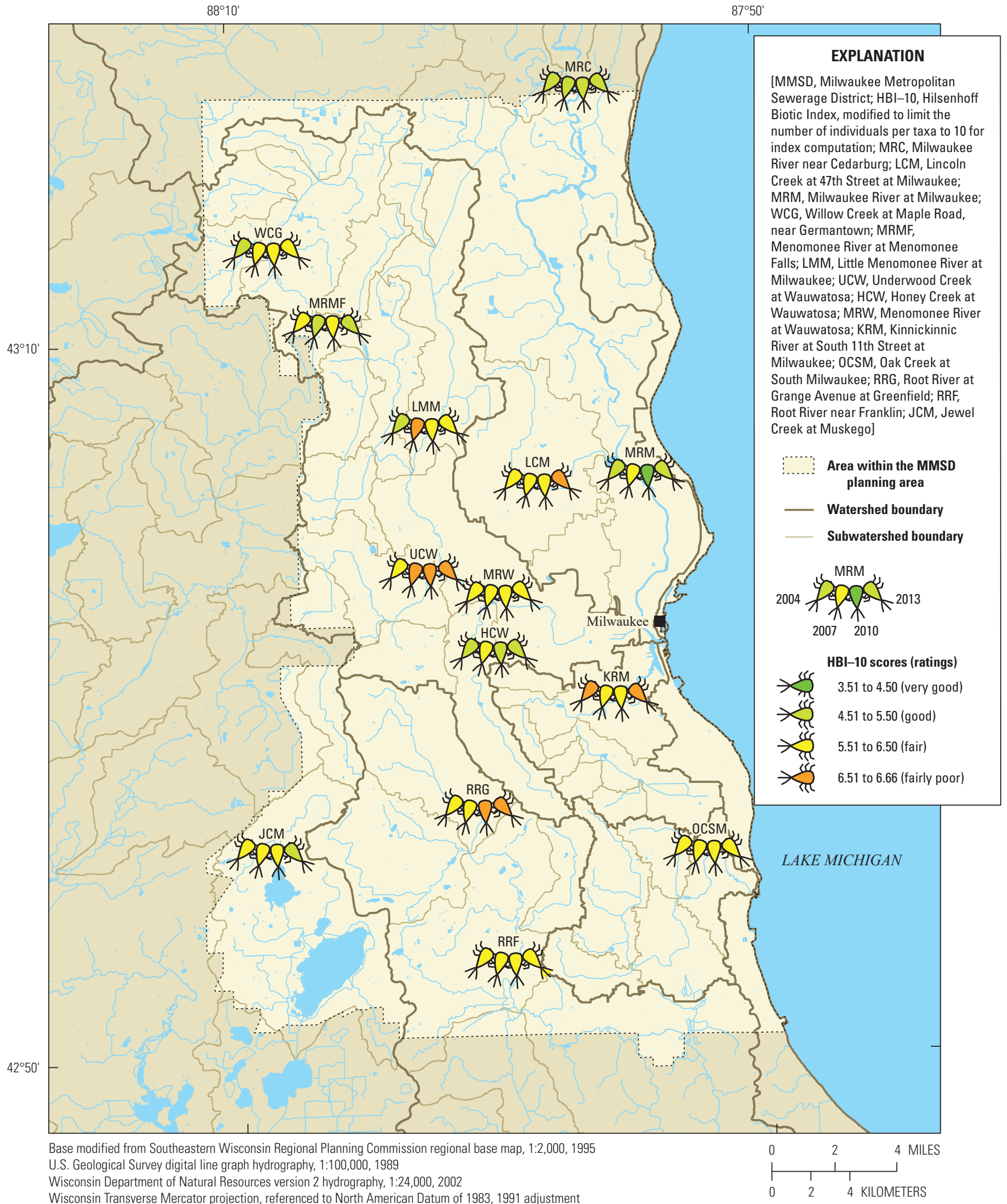

Figure 7. Invertebrate Hilsenhoff Biotic Index scores, modified to limit the number of individuals per taxon to 10 for index computation, for fall samples at 14 stream sites in the Milwaukee Metropolitan Sewerage District planning area, Wisconsin, 2004-13. 
Table 6. Scores and ratings for the fish Index of Biotic Integrity for warmwater streams.

[IBI, Index of Biotic Integrity (Lyons, 1992)]

\begin{tabular}{ll}
\hline IBI score & IBI rating \\
\hline $100-65$ & Excellent \\
$64-50$ & Good \\
$49-30$ & Fair \\
$29-20$ & Poor \\
$19-0$ & Very poor \\
No score & Very poor \\
\hline
\end{tabular}

which differed from the other 3 years. The two main-stem Milwaukee River sites (Milwaukee River near Cedarburg and Milwaukee River at Milwaukee) grouped tightly together but were still distinct and plotted away from the other sites, showing close similarity across years within each site. The fish assemblage at the Lincoln Creek site was quite similar across all years and formed yet another distinct grouping, underscoring the different fish assemblage at this site compared to all other sampled sites. MDS results for the Lincoln Creek, Milwaukee River near Cedarburg, and Menomonee River at Menomonee Falls sites demonstrated little difference within each site for assemblages collected during the temporal sampling when compared with the core sampling years of 2004, 2007, 2010, and 2013, indicating greater differences between sites than within these sites. The assemblages for the Honey Creek and Underwood Creek sites, close tributaries to the Menomonee River at Wauwatosa site, grouped together and with their main-stem site. Lastly, the fish assemblages for the Kinnickinnic River site are anomalies in the MDS plot, emphasizing the small numbers collected of mostly one species.

Overall, the two Milwaukee River main-stem sites (Milwaukee River near Cedarburg and Milwaukee River at Milwaukee) had the highest diversity and the lowest percentages of tolerant fish species compared with other sampled sites (table 7). The lowest diversity was at the Kinnickinnic River site, where a single species, Pimephales promelas (fathead minnow) was collected in 2004 and 2010 (fig. 9A). In 2007, a single Luxilus cornutus (common shiner) was collected in addition to a fathead minnow, and in 2013 not a single fish of any species was detected at the site. At six sites, diversity in 2013 was more than 10 percent lower than in 2004; diversity was more than 10 percent higher in 2013 at only three sites. The declines in diversity indicate degraded fish assemblages. This is particularly concerning for the Milwaukee River near Cedarburg site, which has had the highest fish diversity generally in comparison to all other sampled sites.

Across all metrics computed for the three temporal sites, the lowest coefficient of variation was determined for diversity at less than 15 percent, indicating that values for this metric were fairly consistent or stable for making comparisons among sites. Coefficients of variation for two other metrics, number of species and number of native fish species, were less than or equal to 13 percent at the Milwaukee River near Cedarburg and Menomonee River at Menomonee Falls sites; however, coefficients for these metrics at the Lincoln Creek site were 22-23 percent, possibly because of the relatively small numbers of species at this urban site, so even slight changes result in large coefficients.

Fish species that are considered tolerant of environmental degradation (pollution tolerant and tolerant to low DO) made up more than 40 percent of the assemblages at most sites and nearly 100 percent at several sites in 2013, notably Honey Creek, Menomonee River at Wauwatosa, Kinnickinnic River, Oak Creek, and Root River at Greenfield. The most common fish taxa detected were Catostomus commersonii (white sucker), Lepomis cyanellus (green sunfish), and Semotilus atromaculatus (creek chub). All three taxa are relatively tolerant of disturbance and low DO concentrations (McMahon, 1982). The Milwaukee River near Cedarburg site had the lowest percentage of pollution-tolerant fish overall, followed by the Milwaukee River at Milwaukee site (fig. 9B). Fish that are omnivores are considered tolerant because they can subsist on a wide variety of food types and are therefore less sensitive to environmental degradation (Lyons, 1992). The percentage of omnivores was more than 10 percent lower in 2013 than 2004 at six sites and may indicate an improvement in these assemblages. In addition, percentages of pollution-tolerant fish were at least 10 percent lower at four sites, indicating healthier fish assemblages at these sites.

Fish IBI scores were computed according to the Wisconsin-specific IBI developed by Lyons (1992) and can range from 65 or greater ("excellent") to 0 ("very poor") (table 6). Most sites sampled consistently scored between "fair" and "very poor" ratings (table 7, fig. 9A). The only sites with "good" or "excellent" IBI scores were the two Milwaukee River main-stem sites (Milwaukee River near Cedarburg and Milwaukee River at Milwaukee). Lincoln Creek rated "very poor" in 2004, "fair" in 2007 and 2010, and "very poor" in 2013. The Jewel Creek site was rated "fair" in 2004 and 2013, and the Willow Creek site was rated "poor" in 2013 and in 2004. The Menomonee River at Menomonee Falls site was rated "fair" in 2013 compared with "poor" in 2004. The Underwood Creek site ratings were variable, but the site was rated "fair" in 2013. Fish assemblages at the remaining sites were generally degraded ("poor" and "very poor") and the condition of the assemblages varied through time (fig. 10). The two sites with the poorest fish assemblages across years were the Little Menomonee River and the Kinnickinnic River sites, where fewer than 50 fish were collected during sampling, a number that is too small to compute an IBI with confidence and, therefore, resulted in ratings of "very poor." In these cases, macroinvertebrates are better for assessing the health of the aquatic communities and better reflect conditions at any given site because they are less mobile. Invertebrate HBI-10 ratings were "fair" and "fairly poor" for these two sites, respectively, and these differences in ratings for sites 
Table 7. Comparison of fish-assemblage data at 14 stream sites in the Milwaukee Metropolitan Sewerage District planning area, Wisconsin, $2004-13$.

[The percentage of difference in metric values between fall 2013 and fall 2004 is shown ("Difference"), and percentages greater than 10 percent are highlighted; yellow denotes a potentially adverse difference, and blue denotes a potentially beneficial difference. The coefficient of variation (CV) is provided for comparing 2011-13 at temporal sampling sites; DO, dissolved oxygen; USGS, U.S. Geological Survey; NC, not calculated; *, the score for the Wisconsin warmwater Index of Biotic Integrity (IBI; Lyons, 1992) should be viewed with caution because fewer than 50 individual fish were collected]

\begin{tabular}{|c|c|c|c|c|c|c|c|c|c|}
\hline \multirow[b]{2}{*}{ Collection year } & \multirow[b]{2}{*}{ Number of fish } & \multirow{2}{*}{$\begin{array}{l}\text { Number of } \\
\text { species }\end{array}$} & \multirow{2}{*}{$\begin{array}{l}\text { Number of } \\
\text { native } \\
\text { species }\end{array}$} & \multirow{2}{*}{$\begin{array}{c}\text { Omnivorous } \\
\text { individuals } \\
\text { (percent) }\end{array}$} & \multirow{2}{*}{$\begin{array}{c}\text { Pollution- } \\
\text { tolerant } \\
\text { individuals } \\
\text { (percent) }\end{array}$} & \multirow{2}{*}{$\begin{array}{l}\text { Forage fish } \\
\text { tolerant to low } \\
\text { DO (percent) }\end{array}$} & \multirow{2}{*}{$\begin{array}{c}\text { Shannon } \\
\text { index of } \\
\text { diversity }{ }^{1}\end{array}$} & \multicolumn{2}{|c|}{ Index of Biotic Integrity } \\
\hline & & & & & & & & IBI Score & IBI Rating \\
\hline \multicolumn{10}{|c|}{ Milwaukee River near Cedarburg (USGS station 04086600) } \\
\hline 2004 & 321 & 21 & 20 & 3.0 & 7.8 & 9.0 & 2.61 & 67 & Excellent \\
\hline 2007 & 173 & 15 & 15 & 3.0 & 4.0 & 2.0 & 2.01 & 65 & Excellent \\
\hline 2010 & 877 & 22 & 21 & 8.0 & 9.0 & 1.0 & 2.30 & 77 & Excellent \\
\hline 2011 & 503 & 21 & 20 & 6.0 & 6.2 & 1.0 & 2.27 & 82 & Excellent \\
\hline 2012 & 782 & 19 & 18 & 11 & 14 & 6.0 & 2.27 & 65 & Excellent \\
\hline 2013 & 892 & 21 & 20 & 10 & 11 & 2.0 & 1.91 & 74 & Excellent \\
\hline Difference & 178 & $\mathbf{0}$ & $\mathbf{0}$ & 7.0 & 3.0 & -7.0 & -26.7 & 10 & No difference \\
\hline $\mathrm{CV}$ & 23.6 & 6.1 & 6.4 & 25 & 32 & 95 & 8.43 & 9.6 & NC \\
\hline \multicolumn{10}{|c|}{ Lincoln Creek at 47th Street at Milwaukee (USGS station 040869415) } \\
\hline 2004 & 59 & 8 & 7 & 54 & 71 & 84 & 1.71 & 5 & Very poor \\
\hline 2007 & 170 & 11 & 10 & 16 & 20 & 19 & 1.07 & 49 & Fair \\
\hline 2010 & 124 & 12 & 11 & 24 & 48 & 38 & 1.94 & 45 & Fair \\
\hline 2011 & 116 & 9 & 7 & 55 & 78 & 59 & 1.90 & 12 & Very poor \\
\hline 2012 & 269 & 10 & 8 & 31 & 76 & 69 & 1.66 & 25 & Poor \\
\hline 2013 & 25 & 7 & 7 & 24 & 80 & 73 & 1.50 & 15 & Very poor* \\
\hline Difference & -58 & -13 & $\mathbf{0}$ & -30 & 9.0 & -11 & -12.3 & 200 & No difference \\
\hline $\mathrm{CV}$ & 76 & 22 & 22.9 & 44 & 21 & 26 & 11.9 & 61 & $\mathrm{NC}$ \\
\hline \multicolumn{10}{|c|}{ Milwaukee River at Milwaukee (USGS station 04087000) } \\
\hline 2004 & 244 & 19 & 17 & 10 & 20 & 35 & 2.14 & 57 & Good \\
\hline 2007 & 295 & 19 & 18 & 7.0 & 8.0 & 4.0 & 2.12 & 57 & Good \\
\hline 2010 & 219 & 18 & 16 & 18 & 20 & 5.0 & 2.07 & 59 & Good \\
\hline 2013 & 242 & 19 & 17 & 11 & 14 & 8.0 & 2.29 & 65 & Excellent \\
\hline Difference & -0.8 & 0 & 0.0 & 1.0 & -6.0 & -28 & 7.04 & 14 & Higher \\
\hline
\end{tabular}


Table 7. Comparison of fish-assemblage data at 14 stream sites in the Milwaukee Metropolitan Sewerage District planning area, Wisconsin, 2004-13.-Continued

[The percentage of difference in metric values between fall 2013 and fall 2004 is shown ("Difference"), and percentages greater than 10 percent are highlighted; yellow denotes a potentially adverse difference, and blue denotes a potentially beneficial difference. The coefficient of variation (CV) is provided for comparing 2011-13 at temporal sampling sites; DO, dissolved oxygen; USGS, U.S. Geological Survey; NC, not calculated; *, the score for the Wisconsin warmwater Index of Biotic Integrity (IBI; Lyons, 1992) should be viewed with caution because fewer than 50 individual fish were collected]

\begin{tabular}{|c|c|c|c|c|c|c|c|c|c|}
\hline \multirow[b]{2}{*}{ Collection year } & \multirow[b]{2}{*}{ Number of fish } & \multirow{2}{*}{$\begin{array}{l}\text { Number of } \\
\text { species }\end{array}$} & \multirow{2}{*}{$\begin{array}{c}\text { Number of } \\
\text { native } \\
\text { species }\end{array}$} & \multirow{2}{*}{$\begin{array}{c}\text { Omnivorous } \\
\text { individuals } \\
\text { (percent) }\end{array}$} & \multirow{2}{*}{$\begin{array}{c}\text { Pollution- } \\
\text { tolerant } \\
\text { individuals } \\
\text { (percent) }\end{array}$} & \multirow{2}{*}{$\begin{array}{l}\text { Forage fish } \\
\text { tolerant to low } \\
\text { DO (percent) }\end{array}$} & \multirow{2}{*}{$\begin{array}{l}\text { Shannon } \\
\text { index of } \\
\text { diversity }{ }^{1}\end{array}$} & \multicolumn{2}{|c|}{ Index of Biotic Integrity } \\
\hline & & & & & & & & IBI Score & IBI Rating \\
\hline \multicolumn{10}{|c|}{ Willow Creek at Maple Road, near Germantown (USGS station 040870195) } \\
\hline 2004 & 238 & 6 & 6 & 24 & 60 & 36 & 1.36 & 22 & Poor \\
\hline 2007 & 142 & 12 & 12 & 8.0 & 80 & 56 & 1.96 & 37 & Fair \\
\hline 2010 & 80 & 6 & 6 & 10 & 74 & 48 & 1.59 & 14 & Very poor \\
\hline 2013 & 116 & 7 & 7 & 10 & 54 & 30 & 1.68 & 27 & Poor \\
\hline Difference & $-\mathbf{5 1}$ & 17 & 17 & -14 & -6.0 & -6.0 & 23.7 & 23 & No difference \\
\hline \multicolumn{10}{|c|}{ Menomonee River at Menomonee Falls (USGS station 04087030) } \\
\hline 2004 & 296 & 13 & 13 & 5.0 & 81 & 46 & 1.91 & 25 & Poor \\
\hline 2007 & 212 & 9 & 9 & 5.0 & 58 & 16 & 1.79 & 15 & Very poor \\
\hline 2010 & 121 & 12 & 12 & 2.0 & 83 & 65 & 1.67 & 20 & Poor \\
\hline 2011 & 425 & 13 & 13 & 6.0 & 56 & 17 & 1.76 & 25 & Poor \\
\hline 2012 & 433 & 16 & 16 & 7.0 & 49 & 26 & 2.29 & 35 & Fair \\
\hline 2013 & 117 & 15 & 15 & 8.0 & 28 & 24 & 1.93 & 45 & Fair \\
\hline Difference & -60 & 15 & 15 & 3.0 & -53 & -22 & 1.21 & 80 & Higher \\
\hline $\mathrm{CV}$ & 65 & 13 & 13 & 45 & 42 & 66 & 14.5 & 39 & $\mathrm{NC}$ \\
\hline \multicolumn{10}{|c|}{ Little Menomonee River at Milwaukee (USGS station 04087070) } \\
\hline 2004 & 14 & 5 & 5 & 21 & 93 & 69 & 1.33 & 14 & Very poor* \\
\hline 2007 & 14 & 4 & 4 & 14 & 86 & 57 & 1.15 & 17 & Very poor* \\
\hline 2010 & 35 & 10 & 9 & 9.0 & 49 & 42 & 1.83 & 19 & Very poor* \\
\hline 2013 & 26 & 7 & 7 & 12 & 38 & 64 & 1.78 & 19 & Very poor* \\
\hline Difference & 86 & 40 & 40 & -9.0 & -55 & -5.0 & 33.5 & 36 & No difference \\
\hline \multicolumn{10}{|c|}{ Underwood Creek at Wauwatosa (USGS station 04087088)² } \\
\hline 2004 & 256 & 8.0 & 7.0 & 7.0 & 99 & 7.0 & 1.06 & 10 & Very poor \\
\hline 2007 & 1,051 & 11 & 11 & 17 & 45 & 0 & 1.54 & 30 & Fair \\
\hline 2010 & 59 & 10 & 10 & 22 & 85 & 40 & 1.66 & 7 & Very poor \\
\hline 2013 & 135 & 11 & 11 & 16 & 20 & 6.0 & 1.32 & 44 & Fair \\
\hline Difference & -47 & 38 & 57 & 9.0 & -79 & -1.0 & 24.8 & 340 & Higher \\
\hline
\end{tabular}


Table 7. Comparison of fish-assemblage data at 14 stream sites in the Milwaukee Metropolitan Sewerage District planning area, Wisconsin, 2004-13.-Continued

[The percentage of difference in metric values between fall 2013 and fall 2004 is shown ("Difference"), and percentages greater than 10 percent are highlighted; yellow denotes a potentially adverse difference, and blue denotes a potentially beneficial difference. The coefficient of variation (CV) is provided for comparing 2011-13 at temporal sampling sites; DO, dissolved oxygen; USGS, U.S. Geological Survey; NC, not calculated; *, the score for the Wisconsin warmwater Index of Biotic Integrity (IBI; Lyons, 1992) should be viewed with caution because fewer than 50 individual fish were collected]

\begin{tabular}{|c|c|c|c|c|c|c|c|c|c|}
\hline \multirow[b]{2}{*}{ Collection year } & \multirow[b]{2}{*}{ Number of fish } & \multirow{2}{*}{$\begin{array}{l}\text { Number of } \\
\text { species }\end{array}$} & \multirow{2}{*}{$\begin{array}{l}\text { Number of } \\
\text { native } \\
\text { species }\end{array}$} & \multirow{2}{*}{$\begin{array}{l}\text { Omnivorous } \\
\text { individuals } \\
\text { (percent) }\end{array}$} & \multirow{2}{*}{$\begin{array}{l}\text { Pollution- } \\
\text { tolerant } \\
\text { individuals } \\
\text { (percent) }\end{array}$} & \multirow{2}{*}{$\begin{array}{l}\text { Forage fish } \\
\text { tolerant to low } \\
\text { DO (percent) }\end{array}$} & \multirow{2}{*}{$\begin{array}{l}\text { Shannon } \\
\text { index of } \\
\text { diversity }{ }^{1}\end{array}$} & \multicolumn{2}{|c|}{ Index of Biotic Integrity } \\
\hline & & & & & & & & IBI Score & IBI Rating \\
\hline \multicolumn{10}{|c|}{ Honey Creek at Wauwatosa (USGS station 04087119) } \\
\hline 2004 & 135 & 6 & 6 & 24 & 100 & 16 & 1.28 & 7.0 & Very poor \\
\hline 2007 & 520 & 11 & 10 & 32 & 94 & 11 & 1.58 & 24 & Poor \\
\hline 2010 & 331 & 10 & 9 & 21 & 98 & 12 & 1.34 & 12 & Very poor \\
\hline 2013 & 559 & 11 & 11 & 13 & 97 & 4.0 & 0.85 & 25 & Poor \\
\hline Difference & 314 & 83 & 83 & -11 & -3.0 & -12 & -33.7 & 257 & Higher \\
\hline \multicolumn{10}{|c|}{ Menomonee River at Wauwatosa (USGS station 04087120) } \\
\hline 2004 & 281 & 7 & 7 & 5.0 & 100 & 5.0 & 0.61 & 10 & Very poor \\
\hline 2007 & 449 & 8 & 8 & 4.0 & 72 & 2.0 & 1.14 & 20 & Poor \\
\hline 2010 & 266 & 7 & 7 & 5.0 & 90 & 1.0 & 0.86 & 10 & Very poor \\
\hline 2013 & 284 & 6 & 6 & 6.0 & 95 & 0 & 0.51 & 10 & Very poor \\
\hline Difference & 1.07 & -14 & -14 & -1.0 & -4.9 & -5.0 & -17 & $\mathbf{0}$ & No difference \\
\hline \multicolumn{10}{|c|}{ Kinnickinnic River at South 11th Street at Milwaukee (USGS station 04087159) } \\
\hline 2004 & 11 & 1.0 & 1.0 & 100 & 100 & 100 & 0.00 & 0 & Very poor \\
\hline 2007 & 2 & 2.0 & 2.0 & 50 & 50 & 50 & 0.69 & 4.0 & Very poor \\
\hline 2010 & 42 & 1.0 & 1.0 & 100 & 100 & 100 & 0.00 & 0 & Very poor \\
\hline 2013 & 0 & 0 & 0 & 0 & 0 & 0 & $*$ & * & * \\
\hline Difference & -100 & -100 & -100 & NC & NC & NC & NC & NC & NC \\
\hline \multicolumn{10}{|c|}{ Oak Creek at South Milwaukee (USGS station 04087204) } \\
\hline 2004 & 218 & 7 & 7 & 22 & 94 & 20 & 1.22 & 5.0 & Very poor \\
\hline 2007 & 35 & 5 & 5 & 46 & 97 & 12 & 1.14 & 0 & Very poor* \\
\hline 2010 & 129 & 7 & 6 & 29 & 95 & 44 & 1.37 & 10 & Very poor \\
\hline 2013 & 78 & 6 & 5 & 40 & 95 & 53 & 1.30 & 7.0 & Very poor \\
\hline Difference & -64 & -14 & -29 & 18 & 1.4 & 33 & 6.51 & 40 & No difference \\
\hline
\end{tabular}


[The percentage of difference in metric values between fall 2013 and fall 2004 is shown ("Difference"), and percentages greater than 10 percent are highlighted; yellow denotes a potentially adverse difference, and blue denotes a potentially beneficial difference. The coefficient of variation (CV) is provided for comparing 2011-13 at temporal sampling sites; DO, dissolved oxygen; USGS, U.S. Geological Survey; NC, not calculated; *, the score for the Wisconsin warmwater Index of Biotic Integrity (IBI; Lyons, 1992) should be viewed with caution because fewer than 50 individual fish were collected]

\begin{tabular}{|c|c|c|c|c|c|c|c|c|c|}
\hline \multirow[b]{2}{*}{ Collection year } & \multirow[b]{2}{*}{ Number of fish } & \multirow{2}{*}{$\begin{array}{l}\text { Number of } \\
\text { species }\end{array}$} & \multirow{2}{*}{$\begin{array}{l}\text { Number of } \\
\text { native } \\
\text { species }\end{array}$} & \multirow{2}{*}{$\begin{array}{c}\text { Omnivorous } \\
\text { individuals } \\
\text { (percent) }\end{array}$} & \multirow{2}{*}{$\begin{array}{l}\text { Pollution- } \\
\text { tolerant } \\
\text { individuals } \\
\text { (percent) }\end{array}$} & \multirow{2}{*}{$\begin{array}{l}\text { Forage fish } \\
\text { tolerant to low } \\
\text { DO (percent) }\end{array}$} & \multirow{2}{*}{$\begin{array}{c}\text { Shannon } \\
\text { index of } \\
\text { diversity }{ }^{1}\end{array}$} & \multicolumn{2}{|c|}{ Index of Biotic Integrity } \\
\hline & & & & & & & & IBI Score & IBI Rating \\
\hline \multicolumn{10}{|c|}{ Root River at Grange Avenue at Greenfield (USGS station 04087214) } \\
\hline 2004 & 179 & 9 & 9 & 12 & 94 & 28 & 1.73 & 12 & Very poor \\
\hline 2007 & 10 & 4 & 4 & 10 & 100 & 10 & 1.17 & 12 & Very poor* \\
\hline 2010 & 102 & 8 & 8 & 47 & 98 & 6.0 & 1.32 & 7.0 & Very poor \\
\hline 2013 & 11 & 3 & 3 & 0 & 100 & 55 & 0.99 & 2.0 & Very poor* \\
\hline Difference & -94 & -67 & -67 & -12 & 6.0 & 27 & -43 & -83 & No difference \\
\hline \multicolumn{10}{|c|}{ Root River near Franklin (USGS station 04087220) } \\
\hline 2004 & 184 & 12 & 12 & 55 & 69 & 3.0 & 1.73 & 27 & Poor \\
\hline 2007 & 7 & 4 & 4 & 0 & 57 & 17 & 1.28 & 0 & Very poor* \\
\hline 2010 & 79 & 7 & 7 & 1.0 & 23 & 19 & 1.17 & 32 & Fair \\
\hline 2013 & 31 & 9 & 9 & 16 & 84 & 41 & 1.75 & 17 & Very poor* \\
\hline Difference & -83 & -25.0 & -25 & -39 & 14 & 38 & 1.10 & -37 & Lower \\
\hline \multicolumn{10}{|c|}{ Jewel Creek at Muskego (USGS station 05544371) } \\
\hline 2004 & 511 & 16 & 15 & 36 & 54 & 15 & 1.92 & 31 & Fair \\
\hline 2007 & 144 & 10 & 10 & 9.0 & 42 & 34 & 1.78 & 37 & Fair \\
\hline 2010 & 54 & 6 & 6 & 0 & 17 & 6.0 & 1.26 & 25 & Poor \\
\hline 2013 & 210 & 7 & 7 & 5.0 & 15 & 3.0 & 1.14 & 35 & Fair \\
\hline Difference & -59 & -56 & -53 & -31 & -39 & -12 & -40.5 & 13 & No difference \\
\hline
\end{tabular}

${ }^{1}$ Shannon diversity, calculated as $\log _{\mathrm{e}}$ (Shannon, 1948).

2The 2007 sample included seine hauls at the bottom of the reach; however, we were unable to do this every year because of pool depth. 


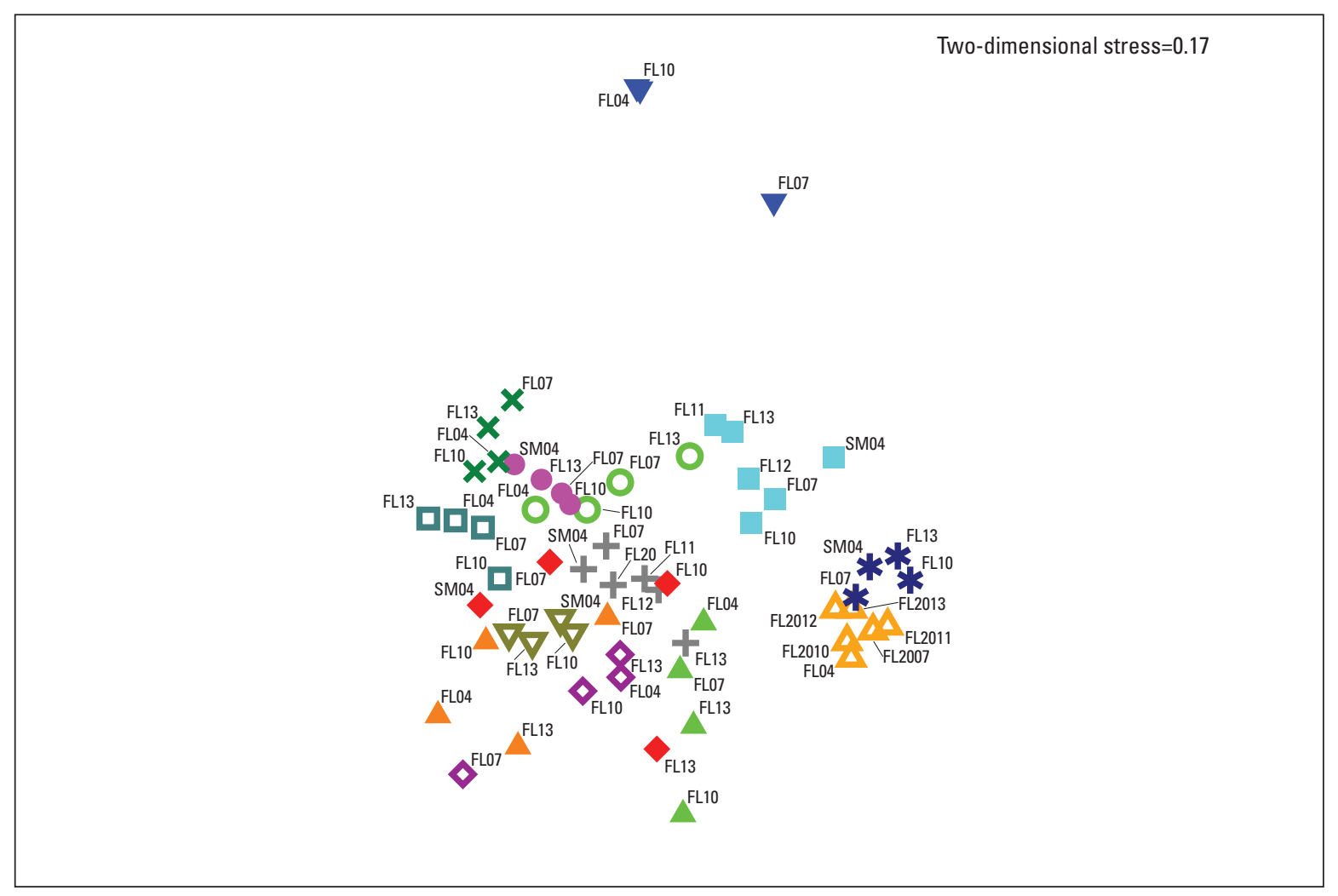

\section{EXPLANATION}

[MRC, Milwaukee River near Cedarburg; LCM, Lincoln Creek at 47th Street at Milwaukee; MRM, Milwaukee River at Milwaukee; WCG, Willow Creek at Maple Road, near Germantown: MRMF Menomonee River at

Menomon Falls: LMM, Little Menomo

Milwauke UCW, Underwood Creek at Wauter at HCW Hoe; Creek at Wausator HCW, Hon Creek at Wa 11th Strot Milws Stro Milwauke, RR, Root River at Grange Avenue at Greenfield, RRF, Root River near Franklin, JCM, Jewel Creek at Muskego; SP, spring samples; $F L$, fall samples; $\mathrm{SM}$, summer samples

\begin{tabular}{cl}
\multicolumn{2}{c}{ Site abbreviatio } \\
MRC \\
LCM \\
* \\
MRM \\
WCG \\
MRMF \\
LMM \\
UCW \\
$\times$ & HCW \\
$\times$ & MRW \\
$\nabla$ & KRM \\
$\nabla$ & OCSM \\
$\square$ & RRG \\
$\nabla$ & RRF \\
\hline & JCM
\end{tabular}

Figure 8. Multidimensional scaling ordination plot for fish assemblages collected at 14 sites in the Milwaukee area, Wisconsin, 2004-13. [The sampling year is shown as $04,07,10,11,12$, and 13 for 2004, 2007, 2010, 2011, 2012, and 2013, respectively] 


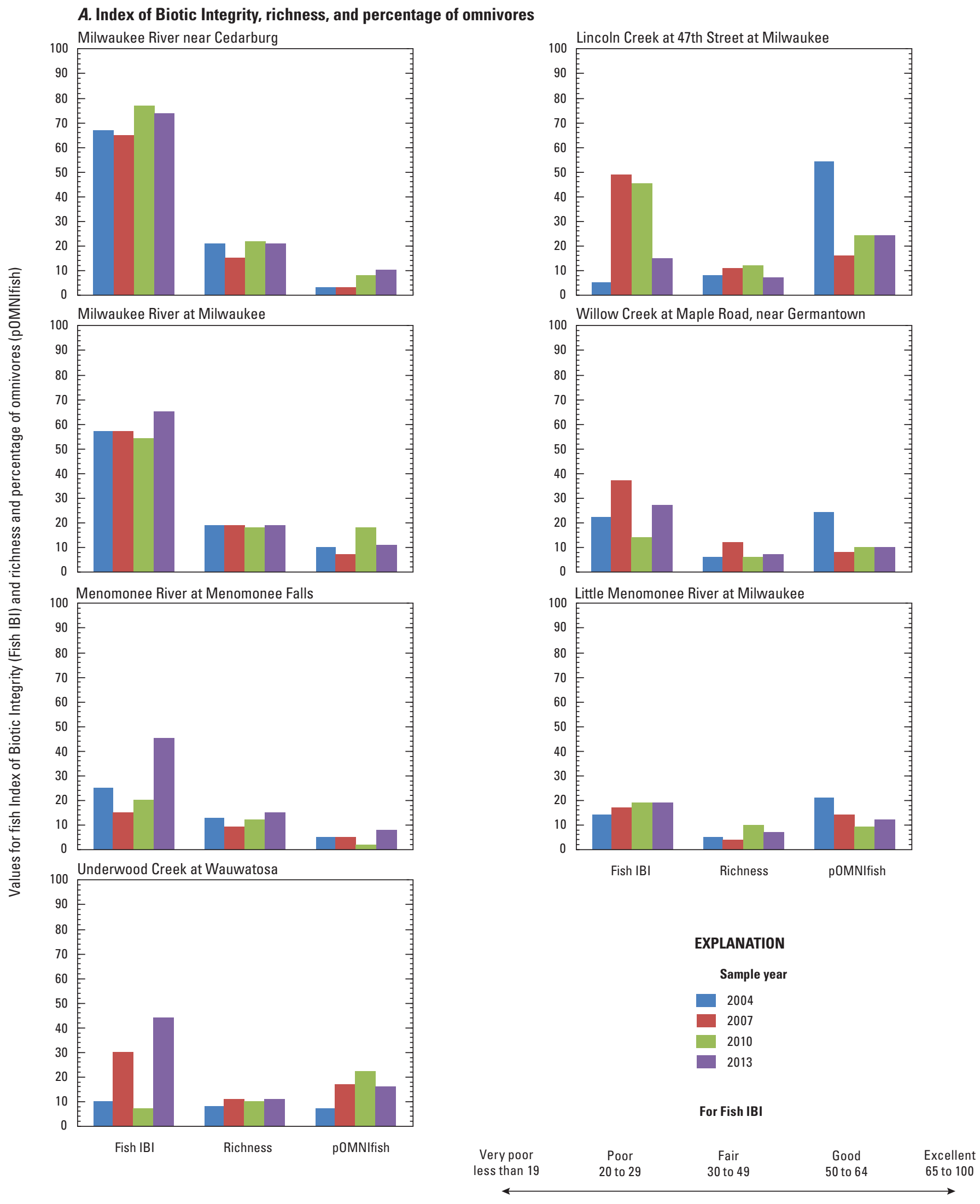

Figure 9. Selected fish metrics for each of the 14 stream sites in the Milwaukee area, Wisconsin, 2004-13. A, Index of Biotic Integrity, richness, and percentage of omnivores; $B$, percentages of tolerant fish, disturbance-tolerant fish, and low dissolved oxygen plus disturbance-tolerant fish. 


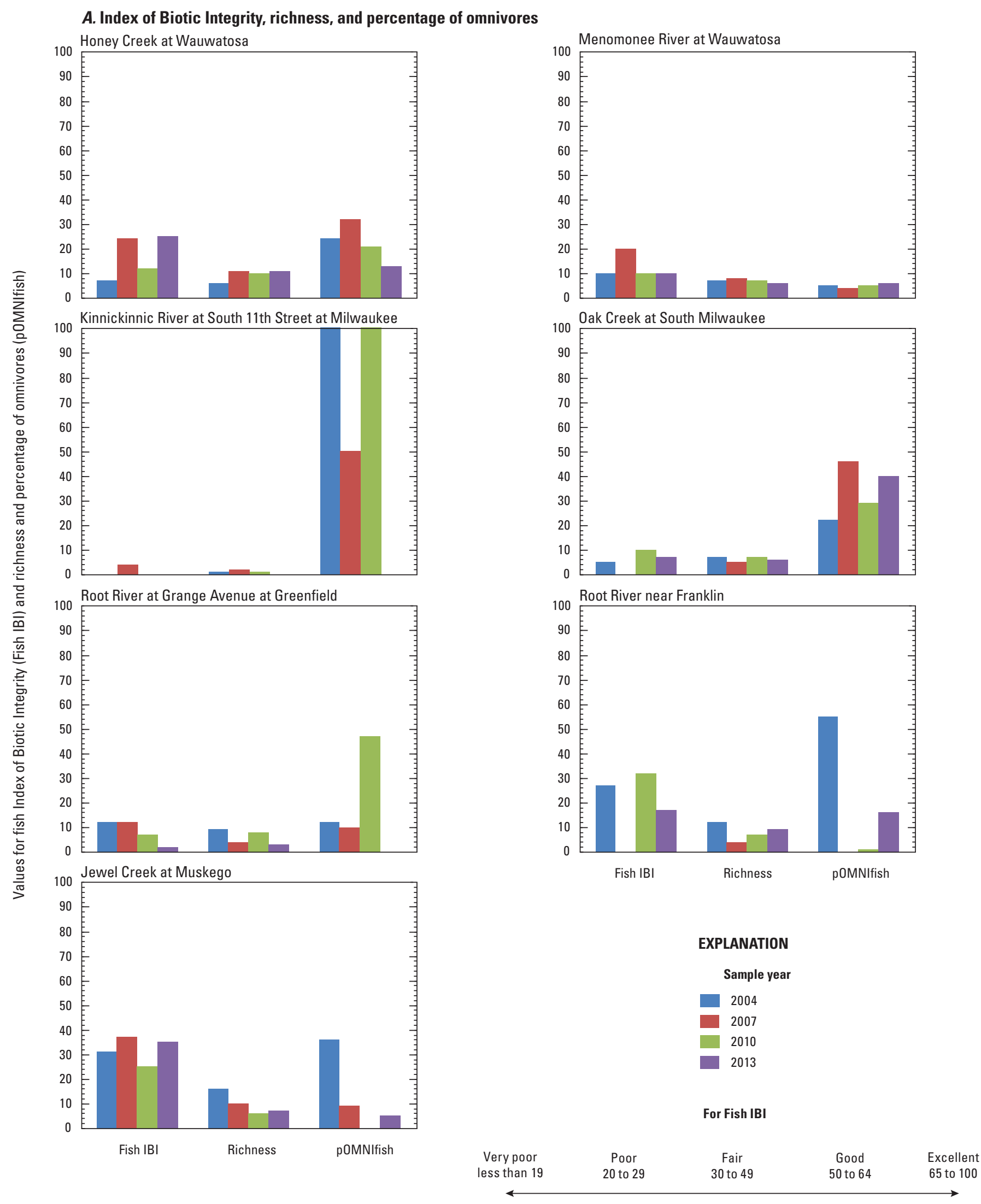

Figure 9. Selected fish metrics for each of the 14 stream sites in the Milwaukee area, Wisconsin, 2004-13. A, Index of Biotic Integrity, richness, and percentage of omnivores; $B$, percentages of tolerant fish, disturbance-tolerant fish, and low dissolved oxygen plus disturbance-tolerant fish.-Continued 


\section{B. Percentages of tolerant fish, disturbance-tolerant fish, and low dissolved oxygen plus disturbance-tolerant fish}
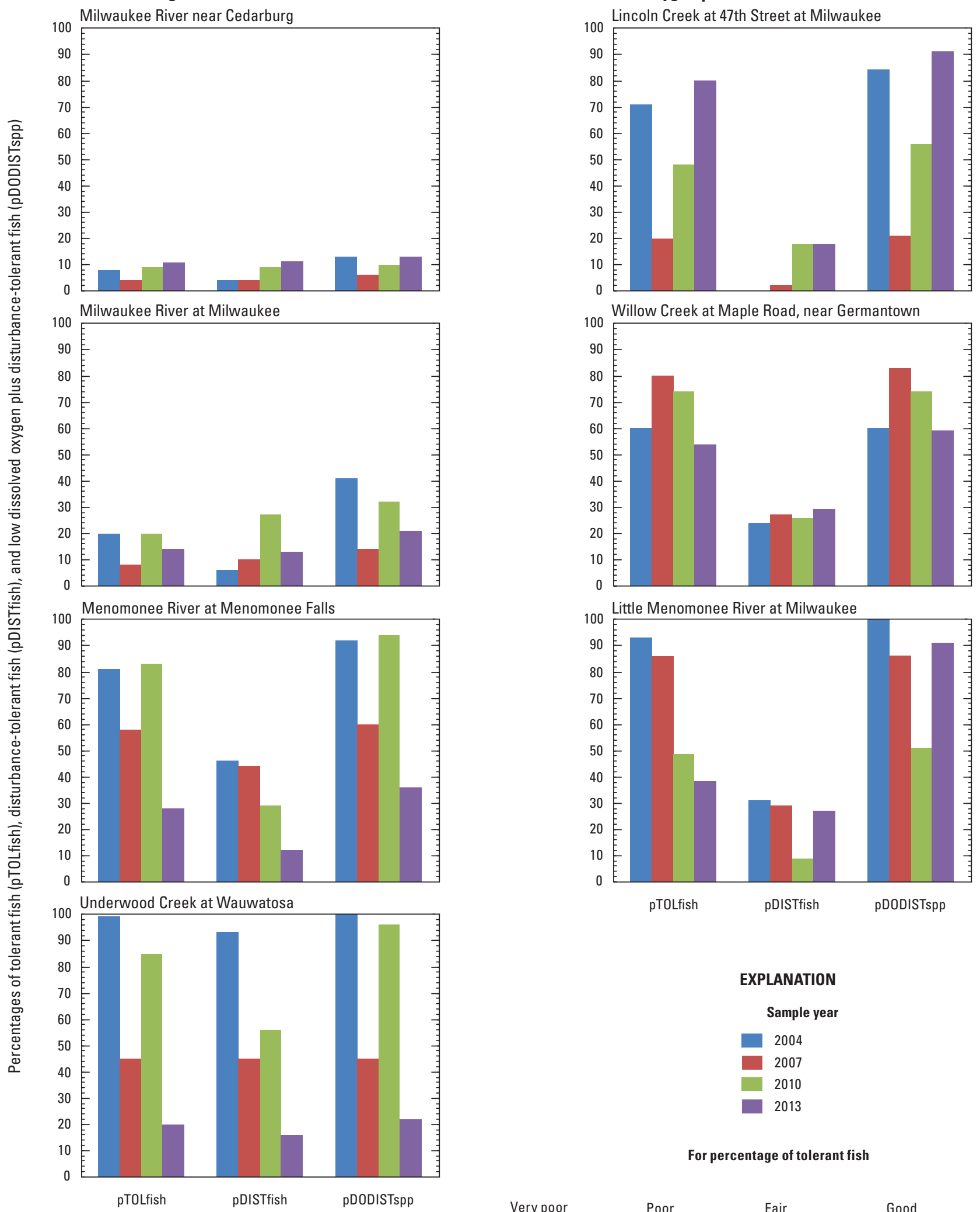

EXPLANATION

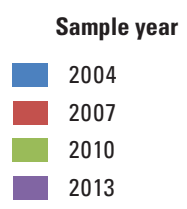

For percentage of tolerant fish

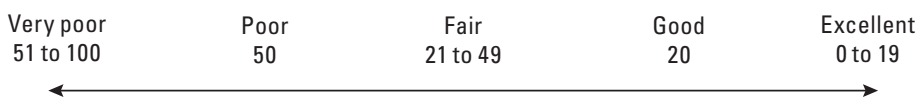

Figure 9. Selected fish metrics for each of the 14 stream sites in the Milwaukee area, Wisconsin, 2004-13. A, Index of Biotic Integrity, richness, and percentage of omnivores; $B$, percentages of tolerant fish, disturbance-tolerant fish, and low dissolved oxygen plus disturbance-tolerant fish.-Continued 
B. Percentages of tolerant fish, disturbance-tolerant fish, and low dissolved oxygen plus disturbance-tolerant fish
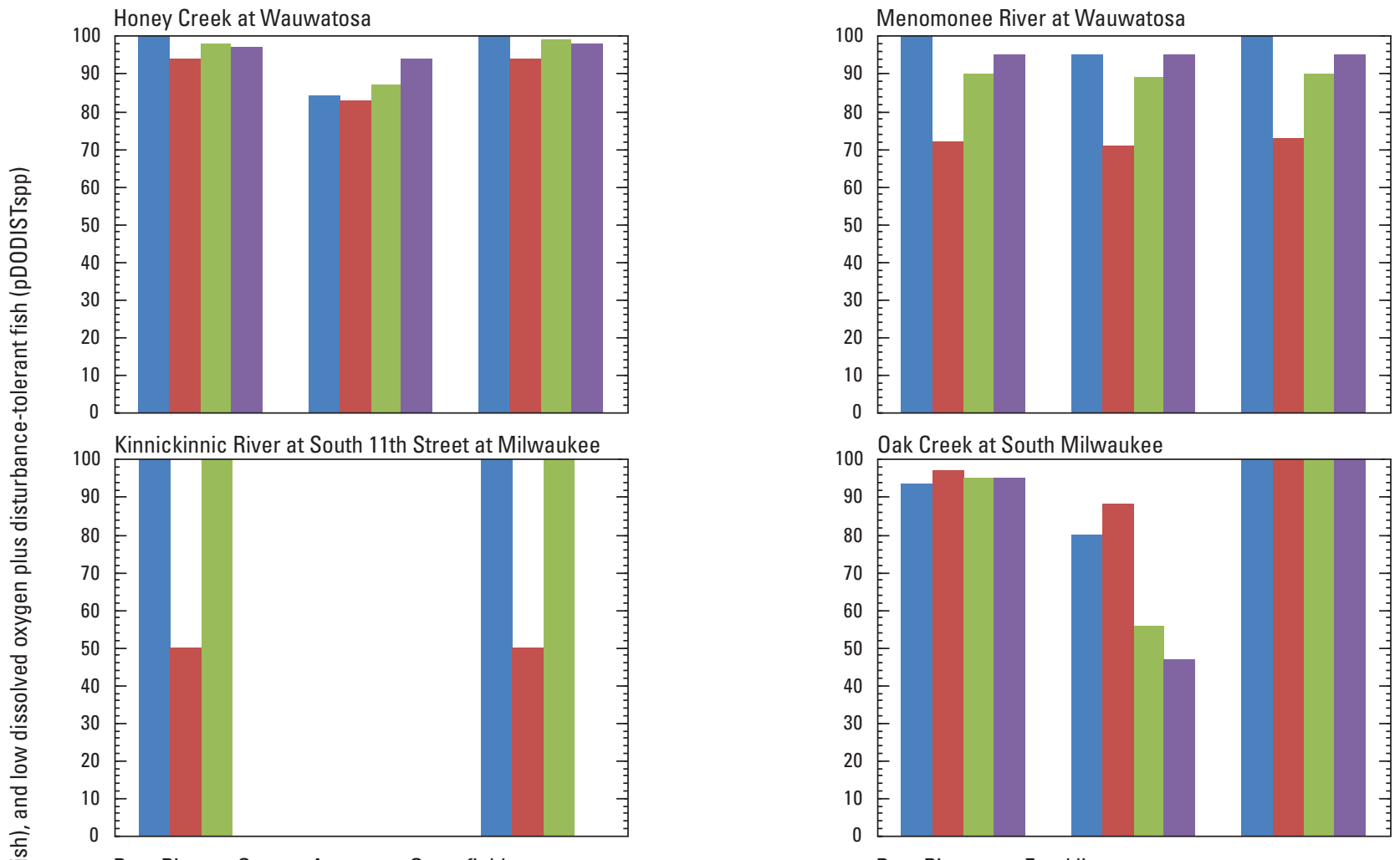

Root River at Grange Avenue at Greenfield

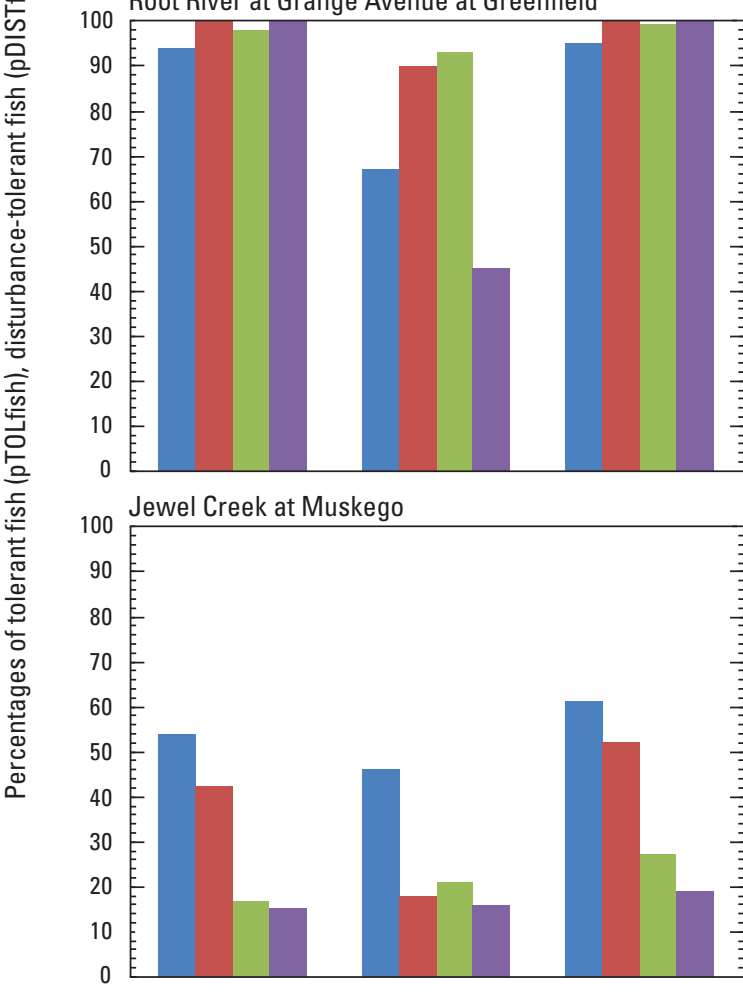

00 Root River near Franklin

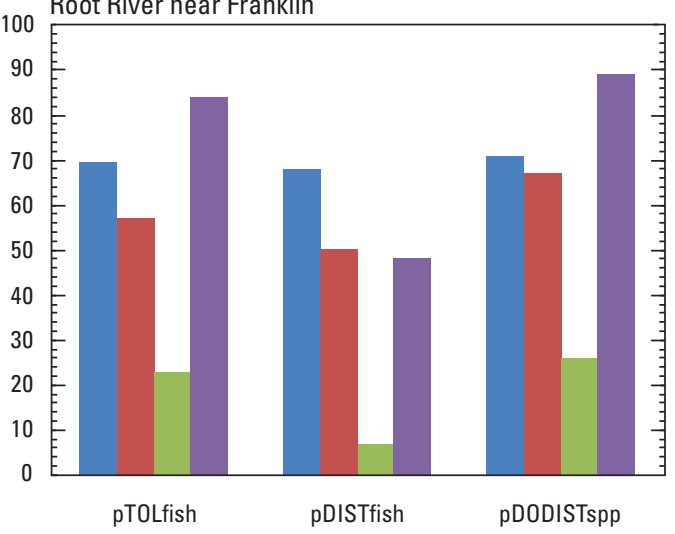

EXPLANATION

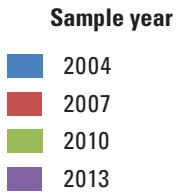

For percentage of tolerant fish

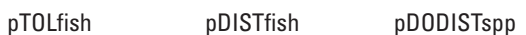

Figure 9. Selected fish metrics for each of the 14 stream sites in the Milwaukee area, Wisconsin, 2004-13. A, Index of Biotic Integrity, richness, and percentage of omnivores; $B$, percentages of tolerant fish, disturbance-tolerant fish, and low dissolved oxygen plus disturbance-tolerant fish.-Continued 


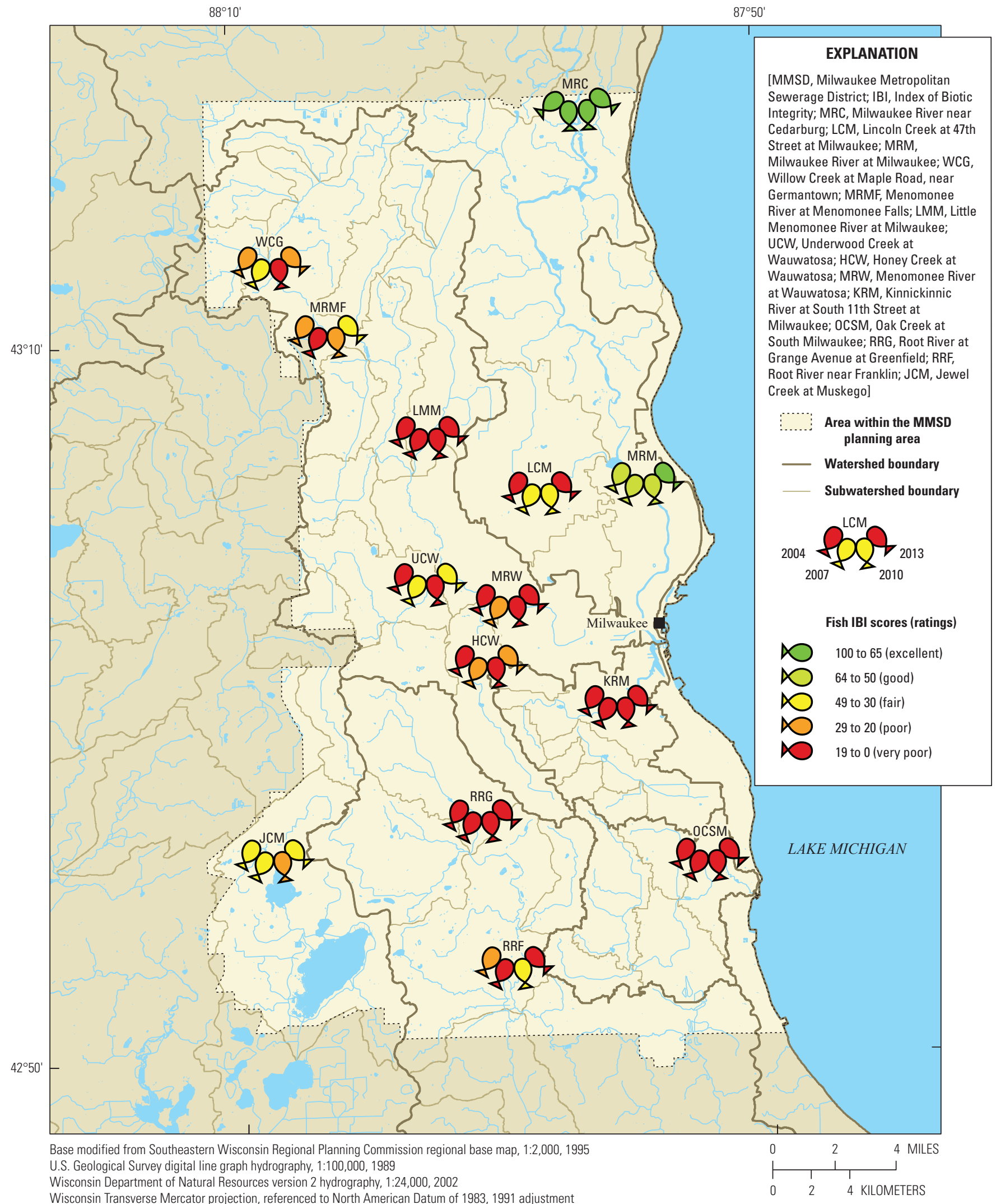

Figure 10. Fish Index of Biotic Integrity scores for fall samples at 14 stream sites in the Milwaukee Metropolitan Sewerage District planning area, Wisconsin, 2004-13. 
based on metrics for fish and invertebrates demonstrate how one group of organisms may respond more adversely than another to environmental degradation.

\section{Comparative Bioassessment among Algae, Invertebrates, and Fish}

Results for selected biological metrics were compared among algal, invertebrate, and fish assemblages to ensure a more complete assessment of water quality and stream condition at the sampled sites. Sites were grouped into four groups according to the aggregate bioassessment rankings. The 4 sites in group 1 for 2013 had the least degraded water quality among the 14 sampled sites: Milwaukee River near Cedarburg, Menomonee River at Menomonee Falls, Jewel Creek, and Milwaukee River at Milwaukee (table 8). This group of sites was also among the least degraded group for 2004 (Thomas and others, 2007). These rankings are arithmetic means for the three biotic assemblages, and as such, results for each assemblage may vary; although the mean invertebrate and fish rankings for the Milwaukee River at Milwaukee site would have placed the site in group 1, the 2013 results for algae placed the site in group 4, the most degraded category. In 2013, relative abundance of pollution-tolerant diatoms increased by more than 10 percent at this site, and this is one of two metrics used in the algal ranking. In general, algal assemblages are more sensitive to water-quality changes occurring on shorter time scales than are invertebrate or fish assemblages. For this reason, algae may be the first to demonstrate improvement or degradation in the water quality at a site. The aggregate assessment rankings for Oak Creek and Honey Creek sites indicate that water quality was better in 2013 than in 2004. The aggregate assessment rankings for the Menomonee River at Wauwatosa and Root River at Greenfield sites indicate that water quality was more degraded in 2013 than in 2004. These two sites, along with the Lincoln Creek and Kinnickinnic River sites composed group 4 in 2013. These aggregate assessments should only be used to compare sites with each other. Sites at the top or bottom of the groups do not indicate good or bad water quality - only better or worse water quality than the other sites evaluated. To fully evaluate the water quality, it is necessary to look at the site-specific biota metrics.

\section{Physical and Chemical Stressors at Sampled Sites}

Physical data were obtained from land use/land cover; stream discharge from USGS streamgages (except at the Willow Creek and Jewel Creek sites, which were not gaged and were not sampled by MMSD for water quality), stream habitat, and microhabitat at invertebrate collection locations (depth, velocity, dominant substrate, embeddedness). Chemical and other water-quality data were obtained from water-quality measurements by MMSD (except at the Willow
Creek and Jewel Creek sites), field measurements of several water-quality constituents (specific conductance and light attenuation) at the time of ecological sampling, and measures of benthic algal biomass. Additional chemical data for stressor evaluations were obtained from toxicity and chemical tests on extracts from passive samplers deployed at a subset of six sites.

\section{Toxicity and Chemical Assessment with Passive Sampling Devices}

Deployment of passive samplers (SPMDs) provided valuable information on the potential toxicity to stream biota from waterborne hydrophobic organic chemicals (PAHs, PCBs, dioxins and furans, chlorinated pesticides, and PBDEs). SPMDs are designed to mimic potential uptake of bioavailable concentrations of these compounds in water by fish gills that could be followed by sequestering of the compounds into fatty lipid-containing areas of the fish (Alvarez and others, 2008; Alvarez, 2010). SPMDs are analyzed by three tests that assess the potential toxicity of bioaccumulative compounds in waterborne sediments: a Microtox test, a P450RGS test, and a fluorescence screen for PAHs.

Microtox tests on SPMDs deployed in 2013 indicated moderate to no toxicity at sites (table 9). Results are reported in terms of $\mathrm{TU}_{50}$ values, which are determined by dividing 100 by the effective concentration at which there is a 50-percent reduction in light; the larger the calculated $\mathrm{TU}_{50}$ value, the more toxic the sample is. SPMDs from the Little Menomonee River and Milwaukee River at Milwaukee sites had the highest $\mathrm{TU}_{50}$ scores, and thus, mixtures of compounds available for bioaccumulation at these sites could be considered to have moderate acute toxicity to aquatic organisms. The SPMDs from the Lincoln Creek and Honey Creek sites had lower $\mathrm{TU}_{50}$ scores that were higher than the field blanks and, therefore, could be considered slightly toxic. Samples from the Oak Creek and Milwaukee River near Cedarburg sites had responses similar to the field blanks and, therefore, were considered to be nontoxic. Field blanks for three of the six sites in 2013 had low measurable responses that were similar to that of the laboratory blank, which was low and had a $\mathrm{TU}_{50}$ of 8.0, and so were considered low/nontoxic (Milwaukee River near Cedarburg [7.2], Lincoln Creek [5.9], and Milwaukee River at Milwaukee [9.4]). Field blanks for the other three sites in 2013 did not indicate toxicity (not detected). In 2007 and 2010, all the SPMD samples demonstrated little to no Microtox toxicity. The lack of toxicity in the 2007 and 2010 Microtox tests was somewhat in contrast to results for 2013 and especially for a previous study in 2004. In 2004, as part of a separate USGS study on the effects of urbanization on stream ecosystems, SPMDs were deployed at or near the same sites included in the current study, and Microtox and P450RGS tests were run (Bryant and Goodbred, 2009; Richards and others, 2010). Microtox results for 2004 indicated that the highest potential toxicity of all Milwaukee area streams sampled was at the 
Table 8. Mean trophic-level rankings and aggregate bioassessment rankings for 14 stream sites in the Milwaukee area, Wisconsin, 2013 and 2004.

[The fill color indicates the group based on percentiles of the ranked data for a group of biota (group 1 or less than the 25th percentile [least degraded], blue; group 2 or between the 25th and 49th percentile/median, light blue; group 3 or between the 50th to 74th percentile, light orange; group 4 or greater than the 75th percentile [most degraded], orange; each column is considered independently). Lower percentiles indicate better water quality. WI, Wisconsin; S., South]

\begin{tabular}{|c|c|c|c|c|c|}
\hline \multirow[b]{2}{*}{ Site name } & \multicolumn{3}{|c|}{ Mean trophic-level ranking for 2013} & \multirow{2}{*}{$\begin{array}{c}2013 \\
\text { Aggregate } \\
\text { bioassessment } \\
\text { ranking }\end{array}$} & \multirow{2}{*}{$\begin{array}{c}2004 \\
\text { Aggregate } \\
\text { bioassessment } \\
\text { ranking }\end{array}$} \\
\hline & Algae 1 & Invertebrates 2 & Fish $^{3}$ & & \\
\hline \multicolumn{6}{|c|}{ Group 1} \\
\hline Milwaukee River near Cedarburg, WI & 5.0 & 1.7 & 1.0 & 2.56 & 1.44 \\
\hline Menomonee River at Menomonee Falls, WI & 3.0 & 3.3 & 3.0 & 3.11 & 5.44 \\
\hline Milwaukee River at Milwaukee, WI & 10.5 & 5.0 & 2.0 & 5.83 & 3.56 \\
\hline \multicolumn{6}{|c|}{ Group 2} \\
\hline Little Menomonee River at Milwaukee, WI & 4.0 & 7.0 & 8.0 & 6.33 & 7.28 \\
\hline Root River near Franklin, WI & 4.5 & 5.7 & 9.0 & 6.39 & 6.39 \\
\hline Honey Creek at Wauwatosa, WI & 10.0 & 7.3 & 7.0 & 8.11 & 9.33 \\
\hline Underwood Creek at Wauwatosa, WI & 10.5 & 12.0 & 4.0 & 8.83 & 9.17 \\
\hline \multicolumn{6}{|c|}{ Group 4} \\
\hline Menomonee River at Wauwatosa, WI & 10.0 & 7.7 & 11.0 & 9.56 & 9.11 \\
\hline Root River at Grange Avenue at Greenfield, WI & 5.0 & 11.7 & 13.0 & 9.89 & 8.56 \\
\hline Lincoln Creek at 47th Street at Milwaukee, WI & 12.5 & 8.7 & 10.0 & 10.39 & 11.11 \\
\hline Kinnickinnic River at S. 11th Street at Milwaukee, WI & 13.0 & 12.7 & 14.0 & 13.22 & 13.06 \\
\hline
\end{tabular}

${ }^{1}$ Averaged bioassessment rankings for algae included the percentage of most tolerant diatoms and the percentage of sensitive diatoms.

${ }^{2}$ Averaged bioassessment rankings for invertebrates included Shannon index of diversity scores, the percentage of Ephemeroptera-Plecoptera-Trichoptera taxa, and Hilsenhoff Biotic Index scores, modified to limit the number of individuals per taxon to 10 for index computation.

${ }^{3}$ Averaged bioassessment rankings for fish included only Index of Biotic Integrity scores.

Underwood Creek site. Compounds that were different from those tested for by the P450RGS tests were likely causing some of the toxicity in those tests because, although results for the P450RGS tests were high at the Underwood Creek site, those results were still lower than several other sampled sites. Based on direct sampling of water and sediment, three possibilities mentioned for toxicity at Underwood Creek in 2004 were 9,10-anthraquinone; tris(2-butoxyethyl) phosphate; and lead (Richards and others, 2010).

In contrast, the P450RGS test results indicated potential toxicity from hydrophobic organic chemicals at all six sites sampled in 2013 (all TEQ values in blank samples were below method detection limits; table 9). High toxic equivalents related to an SPMD extract (TEQs) correspond to similarly high levels of cytochrome-P450 enzyme activity, which are indicators of possible changes in reproduction, growth, pathology, and physiology in fish. In 2013, TEQs at all sites were lower than in 2010; values at the Lincoln Creek, Little
Menomonee River, and Honey Creek sites were 2-3 times lower than in 2010; nevertheless, TEQs in 2013 were higher than in 2007 at the Milwaukee River near Cedarburg, Lincoln Creek, and Honey Creek sites. Potential toxicity was indicated at all these sites in 2007 and at the Little Menomonee River, Kinnickinnic River, and Oak Creek sites. The Lincoln Creek site had the highest potential toxicity in 2007 (set A only), 2010, and 2013 for the P450RGS test. Based on P450RGS tests completed in 2004, the highest potential toxicity from compounds such as dioxins, PCBs, and PAHs for the Milwaukee area was at the Little Menomonee River, Lincoln Creek, Honey Creek (at streamgage), Oak Creek, and Root River at Greenfield (at streamgage) sites (Thomas and others, 2007; Bryant and Goodbred, 2009; Richards and others, 2010); PAHs were detected at all seven sites. Concentrations of PCBs in a sediment trap were low (0.03 milligram per kilogram) at Oak Creek in 2004 (Thomas and others, 2007). In a study of wastewater compounds and toxicity at many 
Table 9. Results for toxicity tests and selected chemical analyses of passive sampling devices (semipermeable membrane devices) deployed at 10 of 14 sites in the Milwaukee area, Wisconsin, 2004-13.

[Each value is a mean of three sample analyses standardized to 30 -day exposure times (higher values indicate greater potential toxicity); $\mathrm{P} 450 \mathrm{RGS}$, cytochrome-P450 reporter gene system toxicity test; $\mathrm{TU}$ (5), toxicity unit for Microtox toxicity tests with values for moderately to highly toxic results given in bold and bold italics, respectively; TEQ, toxic equivalent for cytochrome-P450 tests; PAH, polycyclic aromatic hydrocarbon compound; mg, milligram; SPMD, semipermeable membrane device; mL, milliliter; pg, picogram; $\mu \mathrm{g}$, microgram; A, B, replicate sample sets for 2007; MRC, Milwaukee River near Cedarburg; NC, not characterized; < less than; ND, not detected or detection limits not calculated because of a lack of sampling rate information; LCM, Lincoln Creek at 47th Street at Milwaukee; MRM, Milwaukee River at Milwaukee; MRMF, Menomonee River at Menomonee Falls; LMM, Little Menomonee River at Milwaukee; UCW, Underwood Creek at Wauwatosa; HCW, Honey Creek at Wauwatosa; KRM, Kinnickinnic River at South 11th Street at Milwaukee; OCSM, Oak Creek at South Milwaukee; RRG, Root River at Grange Avenue at Greenfield]

\begin{tabular}{|c|c|c|c|c|c|c|c|c|c|c|c|c|c|c|c|}
\hline \multirow{4}{*}{$\begin{array}{c}\text { Site } \\
\text { abbreviation }\end{array}$} & \multicolumn{5}{|c|}{ Microtox } & \multicolumn{5}{|c|}{ P450RGS } & \multicolumn{5}{|c|}{ Fluoroscan } \\
\hline & \multicolumn{5}{|c|}{$\mathrm{TU}_{50}$} & \multicolumn{5}{|c|}{ TEQ } & \multicolumn{5}{|c|}{ PAH } \\
\hline & \multicolumn{5}{|c|}{ mg SPMD/mL } & \multicolumn{5}{|c|}{ pg TEQ/mL SPMD } & \multicolumn{5}{|c|}{ $\mu \mathrm{g}$ pyrene equivalents/mL SPMD } \\
\hline & 12004 & 2007-A & 2007-B & 2010 & 2013 & 12004 & 2007-A & 2007-B & 2010 & 2013 & 12004 & 2007-A & 2007-B & 2010 & 2013 \\
\hline MRC & $\mathrm{NC}$ & $<1.2$ & $<5.2$ & ND & 6.7 & $\mathrm{NC}$ & 491 & 547 & 1,496 & 871 & $\mathrm{NC}$ & 0.484 & 0.523 & 7.31 & 1.5 \\
\hline LCM & 16.3 & 5.5 & 12.2 & 2.3 & 13.7 & 2,217 & 2,430 & 2,490 & 9,018 & 3,024 & 417.5 & 2.88 & 2.85 & 41.2 & 2.3 \\
\hline MRM & $\mathrm{NC}$ & $\mathrm{NC}$ & $\mathrm{NC}$ & 5.7 & 42.9 & $\mathrm{NC}$ & $\mathrm{NC}$ & $\mathrm{NC}$ & 2,977 & 1,736 & $\mathrm{NC}$ & $\mathrm{NC}$ & $\mathrm{NC}$ & 29.8 & 0.96 \\
\hline MRMF & 41.0 & $\mathrm{NC}$ & $\mathrm{NC}$ & $\mathrm{NC}$ & $\mathrm{NC}$ & 1,776 & $\mathrm{NC}$ & $\mathrm{NC}$ & $\mathrm{NC}$ & $\mathrm{NC}$ & 678.9 & $\mathrm{NC}$ & $\mathrm{NC}$ & $\mathrm{NC}$ & $\mathrm{NC}$ \\
\hline LMM & 43.5 & $<1.2$ & $<5.2$ & 4.3 & 38.2 & 2,889 & 1,980 & 2,660 & 7,602 & 2,209 & 1,295 & 3.58 & 5.46 & 38.1 & 1.8 \\
\hline $\mathrm{UCW}^{2}$ & 270.3 & $\mathrm{NC}$ & $\mathrm{NC}$ & $\mathrm{NC}$ & $\mathrm{NC}$ & 1,028 & $\mathrm{NC}$ & $\mathrm{NC}$ & $\mathrm{NC}$ & $\mathrm{NC}$ & 148.6 & $\mathrm{NC}$ & $\mathrm{NC}$ & $\mathrm{NC}$ & $\mathrm{NC}$ \\
\hline $\mathrm{HCW}^{2}$ & 13.1 & $<1.2$ & $<5.2$ & 4.9 & 11.5 & 2,162 & 2,280 & 1,900 & 7,004 & 2,762 & 580.4 & 3.85 & 0.042 & 29.5 & 3.0 \\
\hline KRM & $\mathrm{NC}$ & $<1.2$ & $<5.2$ & $\mathrm{NC}$ & $\mathrm{NC}$ & $\mathrm{NC}$ & 970 & 3,360 & $\mathrm{NC}$ & $\mathrm{NC}$ & $\mathrm{NC}$ & 8.07 & 8.36 & $\mathrm{NC}$ & $\mathrm{NC}$ \\
\hline OCSM & 29.7 & $<1.2$ & $<5.2$ & 5.8 & 7.3 & 2,392 & 457 & 2,000 & 2,154 & 1,397 & 362.3 & 2.02 & 1.62 & 14.1 & 1.8 \\
\hline $\mathrm{RRG}^{2}$ & 31.3 & $\mathrm{NC}$ & $\mathrm{NC}$ & $\mathrm{NC}$ & $\mathrm{NC}$ & 2,459 & $\mathrm{NC}$ & $\mathrm{NC}$ & $\mathrm{NC}$ & $\mathrm{NC}$ & 587.2 & $\mathrm{NC}$ & $\mathrm{NC}$ & $\mathrm{NC}$ & $\mathrm{NC}$ \\
\hline
\end{tabular}

${ }^{1}$ Results from a separate U.S. Geological Survey study as reported in Thomas and others (2007).

2Underwood Creek at Watertown Plank Road at Elm Grove (about 3 miles upstream from Underwood Creek at Wauwatosa), Honey Creek near Portland Avenue at Wauwatosa (about 1 mile upstream from Honey Creek at Wauwatosa), and Root River at Layton Avenue at Greenfield (about 2 miles upstream from the Root River at Grange Avenue at Greenfield). 
of the same streams, Baldwin and others (2013) reported that the lowest weights for toxicity tests with Ceriodaphnia dubia were measured at the two Milwaukee main-stem sites (Milwaukee River near Cedarburg and Milwaukee River at Milwaukee) and also the Willow Creek site.

Results from the Fluoroscan fluorescence screen for PAHs in SPMDs indicated that the concentrations of the PAH indicator pyrene were low in 2013, generally at only a factor of two greater than the field blanks, and concentrations were highest at the Lincoln Creek and Honey Creek sites (table 9). PAH concentrations in 2010, however, were several times higher at all six sites and the highest pyrene concentrations were at the Lincoln Creek and Little Menomonee River sites; concentrations in all blanks were less than method detection limits. These results were similar to the 2010 results for P450RGS tests, where TEQs were much higher than in other years. SPMDs in 2010 were deployed 5-12 days after historic floods in July 2010, and samplers may have been exposed to additional PAH-laden runoff in floodwaters. In general, concentrations in 2007 were more similar to concentrations in 2013, except for the Lincoln Creek site where the highest pyrene and total PAHs among all six sample sites were measured in 2007 (Scudder Eikenberry and others, 2010). In 2004, the highest PAH concentrations were at the Little Menomonee River and Menomonee River at Menomonee Falls sites, and the highest pyrene concentrations were at the Little Menomonee River site, followed by the Menomonee River at Menomonee Falls and the Root River at Greenfield sites. Concentrations of PAHs were also high at the Lincoln Creek, Honey Creek, and Oak Creek sites in 2004 (Thomas and others, 2007); relative comparisons only are made for the 2004 values because they are orders of magnitude higher than values for other years (table 9).

Baldwin and others (2013) determined that concentrations of PAHs in Milwaukee area stormflows were related to the percentage of urban land in the watershed and that urban storm runoff was an important source of PAHs and other organic waste compounds to area streams. In a later study, Baldwin and others (2017) identified coal-tar sealcoat from parking lots and roads as the primary source of PAHs to area streams; the City of Milwaukee banned coal-tar sealcoats in 2017 (Milwaukee Journal Sentinel, 2017). PAHs are the largest class of suspected human carcinogens and are common urban contaminants, formed mainly during incomplete burning of fuel, primarily petroleum, oil, coal, and wood (Bjørseth and Ramdahl, 1985; Van Metre and others, 2000, 2009). Urban sources include not only emissions and wastes from these processes but also commonly used coal-tar pavement sealants (Mahler and others, 2005; Van Metre and others, 2009). PCBs are highly toxic at low concentrations and break down slowly in the environment; thus, despite a ban on PCBs in 1979, they are still a concern (Mahler and others, 2005). The Milwaukee Estuary was named a Great Lakes Area of Concern in the late 1980s because of severe sediment contamination, primarily from PCBs but also from PAHs (Wisconsin Department of Natural Resources, 2013). PBDEs are a component of flame retardants in many consumer products and are persistent, bioaccumulative, and toxic (Siddiqi and others, 2003; U.S. Environmental Protection Agency, 2017). Dioxins and furans are also highly toxic and persistent chemicals that are produced as byproducts of certain industrial processes; they are still present in the environment despite control of industrial sources beginning in the late 1980s (National Institute of Environmental Health Sciences, 2017).

In summary, tests with SPMDs indicate potential toxicity from synthetic organic chemicals at all six sites sampled in 2013 (table 9), with the highest potential toxicity at the Little Menomonee River, Milwaukee River at Milwaukee, Lincoln Creek, and Honey Creek sites. In 2013, the Milwaukee River at Milwaukee and Little Menomonee River sites had moderate acute toxicity based on Microtox tests. The Lincoln Creek, Honey Creek, and Little Menomonee River sites ranked the highest for toxicity from compounds such as dioxins, PCBs, and PAHs based on the P450RGS test, and the Lincoln Creek and Honey Creek sites were highest for PAHs in 2013, based on Fluoroscan tests with pyrene as an indicator.

\section{Relations between Biological Metrics and Environmental Stressors}

Relations between biological metrics and measured environmental stressors, including chemical and physical stressors and stream habitat, were examined across sampling years from 2004 to 2013. The relations to environmental stressors were examined separately for each group of aquatic biota. Many of the correlations detected were not simple linear relations but instead had an "L" or inverted " $L$ " shape that may indicate a threshold effect - at low values of the explanatory variable, there are decreases in the biological metric and then at some point, the biological metric drops markedly to zero or a minimal value. There were also wedge-shaped distributions commonly seen in ecological studies that represent factor ceilings, the highest biological metric value attained given the environmental stressors present (Carter and Fend, 2005; Carter and others, 2009). Factor ceilings can be useful management tools. Environmental metrics correlated to algae, invertebrates, and fish are shown in figures 11-13 and are summarized in table 10 .

\section{Algae}

Several algal metrics correlated significantly with environmental stressors: high total phosphorus-indicator diatoms (optima greater than or equal to $0.100 \mathrm{mg} / \mathrm{L}$ ), $\alpha$-mesosaprobous diatoms (moderately tolerant taxa associated with DO saturations of 25-70 percent and BOD5 values of 4-13 mg/L), diatoms sensitive to nutrient and organic enrichment, facultative nitrogen-heterotrophic diatoms (taxa requiring periods of high organically bound nitrogen), nitrogenautotrophic diatoms (indicating low organic nitrogen), fairly high oxygen tolerance or requirements (more than 75-percent saturation) diatoms, high calcium optima (more than $40 \mathrm{mg} / \mathrm{L}$ ) 
diatoms, and diatoms with tolerance or requirements for dissolved salts (halobiontic) (fig. 11). Nondiatom metrics that correlated significantly with environmental stressors were soft algae with low chloride optima (less than $15 \mathrm{mg} / \mathrm{L}$ ), soft algae with low suspended-sediment optima (less than $15 \mathrm{mg} / \mathrm{L}$ ), and sestonic (planktonic) algae. Several other algal metrics also correlated with environmental metrics but with poorer relations and redundancy with the algal metrics mentioned previously.

With respect to water quality, algal metrics indicated high concentrations of nitrogen and DO. Higher mean concentrations of ammonia nitrogen correlated positively to higher abundances of diatoms with fairly high oxygen tolerance or requirements and to lower abundances of sestonic algae $(p<0.001$; fig. $11 A$ and $B$ ). Sestonic algae are more common in settings with higher nutrient concentrations (Heiskary and Bouchard, 2015). The highest mean concentrations of ammonia nitrogen were measured at the Little Menomonee River site in 2007-13 but, with mean $\mathrm{pH}$ considered (mean $\mathrm{pH}$ was 7.7 during the same period), mean ammonia nitrogen concentrations at this site did not seem to exceed chronic toxicity levels. Ammonia nitrogen is a potential toxin to aquatic organisms. Ammonia nitrogen has anthropogenic sources (for example, sewage effluent and runoff from industry, urban areas, and agriculture), and it has natural sources (for example, fixation of atmospheric nitrogen and hydrogen by microorganisms such as blue-green algae [U.S. Environmental Protection Agency, 2013]). In a study of the effects of urbanization on aquatic communities, Coles and others (2009) determined that differences in algal assemblages correlated with higher total nitrogen, alkalinity, and specific conductance for streams in the Milwaukee and Green Bay areas (with some site overlap with the current study). Other indicators of high nutrients were also reflected by algal metrics. Higher concentrations of total nonpurgeable inorganic carbon, the form of which (carbon dioxide, bicarbonate, and carbonate) is $\mathrm{pH}$ dependent and important in photosynthesis, correlated to lower abundances of diatom taxa that are indicative of organic enrichment: $\alpha$-mesosaprobous diatoms and facultative nitrogen-heterotrophic diatoms ( $p<0.001$; fig. $11 C$ and $D$ ). Streams affected by excess nutrients can also experience large diurnal swings in DO concentrations, with high DO from algal photosynthesis during sunlight hours followed by low DO from algal respiration at night. Higher mean DO concentrations correlated negatively with lower abundances of three moderate to sensitive algal groups: diatoms with fairly high oxygen tolerance, algae with low chloride optima, and soft algae with low suspendedsediment optima ( $p<0.001$; fig. $11 E, F$, and $G)$. Also, higher values for BOD5 (an indicator of the amount of biodegradable organic material in the water; that is, the degree of organic pollution) and fecal coliform bacteria (an indicator of human or other animal waste in the water) correlated significantly to higher abundances of high total phosphorus-indicator diatoms $(p<0.001$; fig. $11 H$ and $I$ ). BOD5 and animal waste serve as nutrient sources to algae in streams.
Runoff into streams was reflected in the algal metrics. Higher concentrations of total zinc also correlated to higher abundances of high total phosphorus-indicator diatoms $(p<0.001$; fig. $11 \mathrm{~J})$. Zinc is a common pollutant in urban storm runoff from outdoor galvanized surfaces (siding and roofs) and parking lot and road surfaces (tire wear debris) (University of Wisconsin-Extension and Wisconsin Department of Natural Resources, 1997; Davis and others, 2001; California Stormwater Quality Association, 2015). The maximum instantaneous discharge per drainage area correlated significantly to higher abundances of high total phosphorus-indicator diatoms $(p<0.001$; fig. $11 K)$. The metric for maximum instantaneous discharge per drainage area is an indicator of flood and scour effects, and values greater than about 80 cubic feet per second per square mile correlated to a large decrease in the percentage of diatoms with high calcium optima associated with higher conductivity water $(p<0.001$; fig. $11 L)$. This finding may simply reflect dilution of major ion concentrations at higher stream discharge but concentrations can also be higher on initial flush during a runoff event.

With respect to land-use/land-cover relations to algae, correlations again reflected an urban signature. Higher percentages of medium and high-intensity developed land, and urban land in the stream buffer, and higher percentages of impervious surface in the watershed were all highly correlated with each other (Spearman's rank correlation coefficient $[$ rho] $\geq 0.93$ ), and these metrics correlated to higher abundances of high total phosphorus-indicator diatoms $(p<0.001$; fig. $11 M-O, T$ ). Higher percentages of deciduous forest in the watershed were significantly related to decreases in high total phosphorus-indicator diatoms and facultative nitrogenheterotrophic diatoms $(p<0.001$; fig. $11 Q$ and $R)$. At about 14-percent deciduous forest, a large decrease was seen in these diatom metrics that indicated a possible benefit for having higher percentages of deciduous forest in the watershed. In contrast, higher percentages of impervious surface in the watershed were correlated to lower abundances of diatoms sensitive to nutrient and organic enrichment. Similar to the effect of deciduous forest on high nutrient-indicator diatoms, higher percentages of mixed forest correlated significantly to decreases in diatoms with a tolerance or requirement for dissolved salts, indicating that as little as 1-percent mixed forest in the watershed might be beneficial with regard to reducing salt runoff into these streams $(p<0.001$; fig. $11 S)$.

Lastly, stream habitat metrics related to nutrients and oxygen also correlated significantly with algal metrics. The abundance of total phosphorus-indicator diatoms increased with urban land in the stream buffer $(p<0.001$; fig. 11T). Higher coefficients of variation in the stream depth correlated significantly with higher abundances of facultative nitrogenheterotrophic diatoms $(p<0.001$; fig. $11 U)$. This group of diatoms requires periodic high concentrations of organically bound nitrogen in the water that are associated with organic enrichment. Related to this, higher mean embeddedness correlated significantly with higher abundances of nitrogenautotrophic diatoms, taxa that are usually intolerant of high 

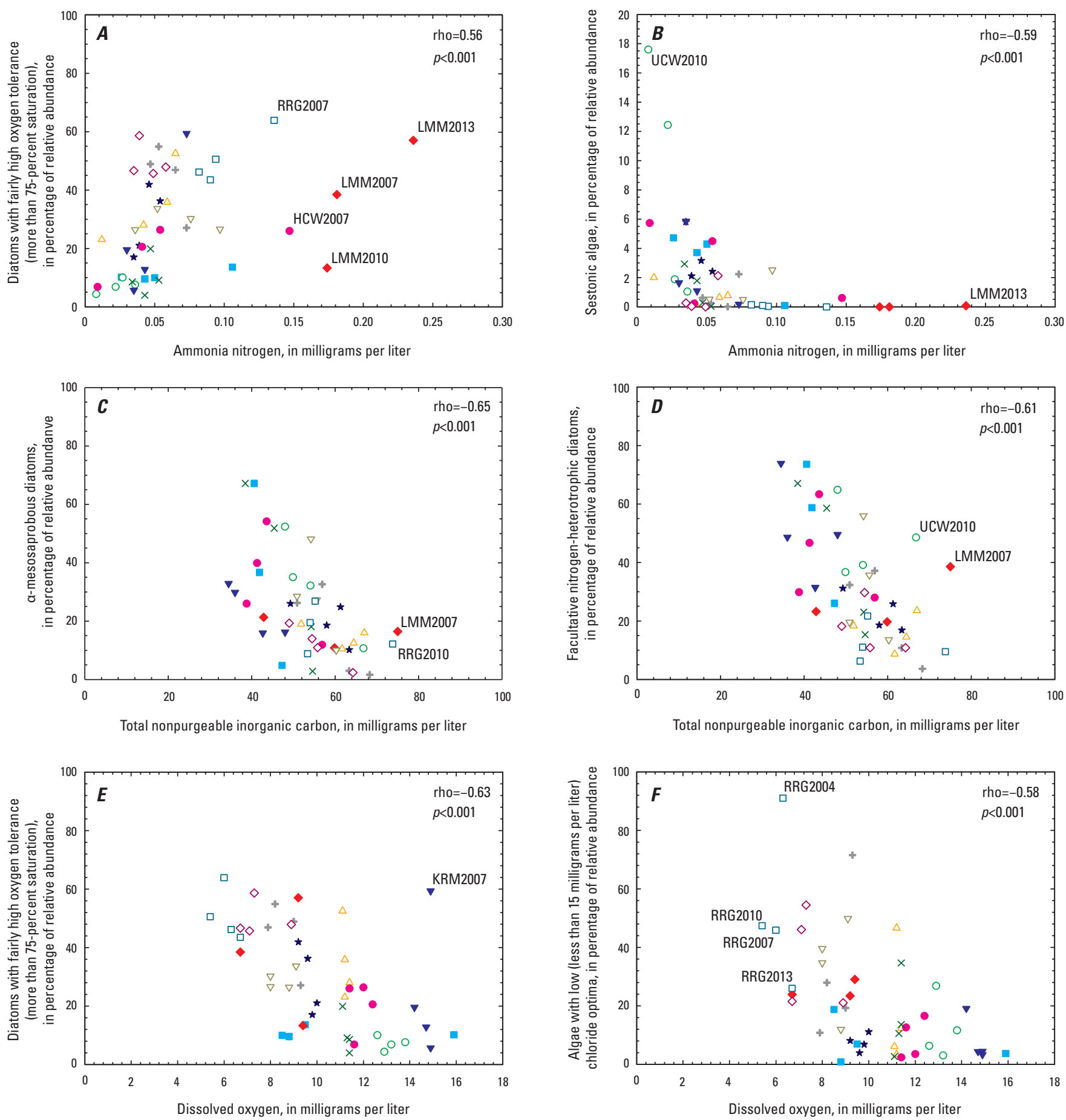

\section{EXPLANATION}

[rho, Spearman's rank correlation coefficient; $p$, probability value; <, less than; MRC, Milwaukee River near Cedarburg; LCM, Lincoln Creek at 47th Street at Milwaukee; MRM, Milwaukee River at Milwaukee; WCG, Willow Creek at Maple Road, near Germantown; MRMF, Menomonee River at Menomonee Falls; LMM, Little Menomonee River at Milwaukee; UCW, Underwood Creek at Wauwatosa; HCW, Honey Creek at Wauwatosa; MRW, Menomonee River at Wauwatosa; KRM, Kinnickinnic River at South 11th Street at Milwaukee; OCSM, Oak Creek at South Milwaukee; RRG, Root River at Grange Avenue at Greenfield; RRF, Root River near Franklin; JCM, Jewel Creek at Muskego]

$$
\begin{array}{lllllll}
\triangle \text { MRC } & \star \text { MRM } & + \text { MRMF } & \circ \text { UCW } & \times \text { MRW } & \nabla \text { OCSM } & \diamond \text { RRF } \\
\square \text { LCM } & \triangle \text { WCG } & \diamond \text { LMM } & \bullet \text { HCW } & \nabla \text { KRM } & \square \text { RRG } & \triangle \text { JCM }
\end{array}
$$

Figure 11. Relations between algal metrics and environmental metrics for 14 streams in the Milwaukee area, Wisconsin, $2004-13$. Environmental metrics for water quality are means for the year of ecological sampling. 

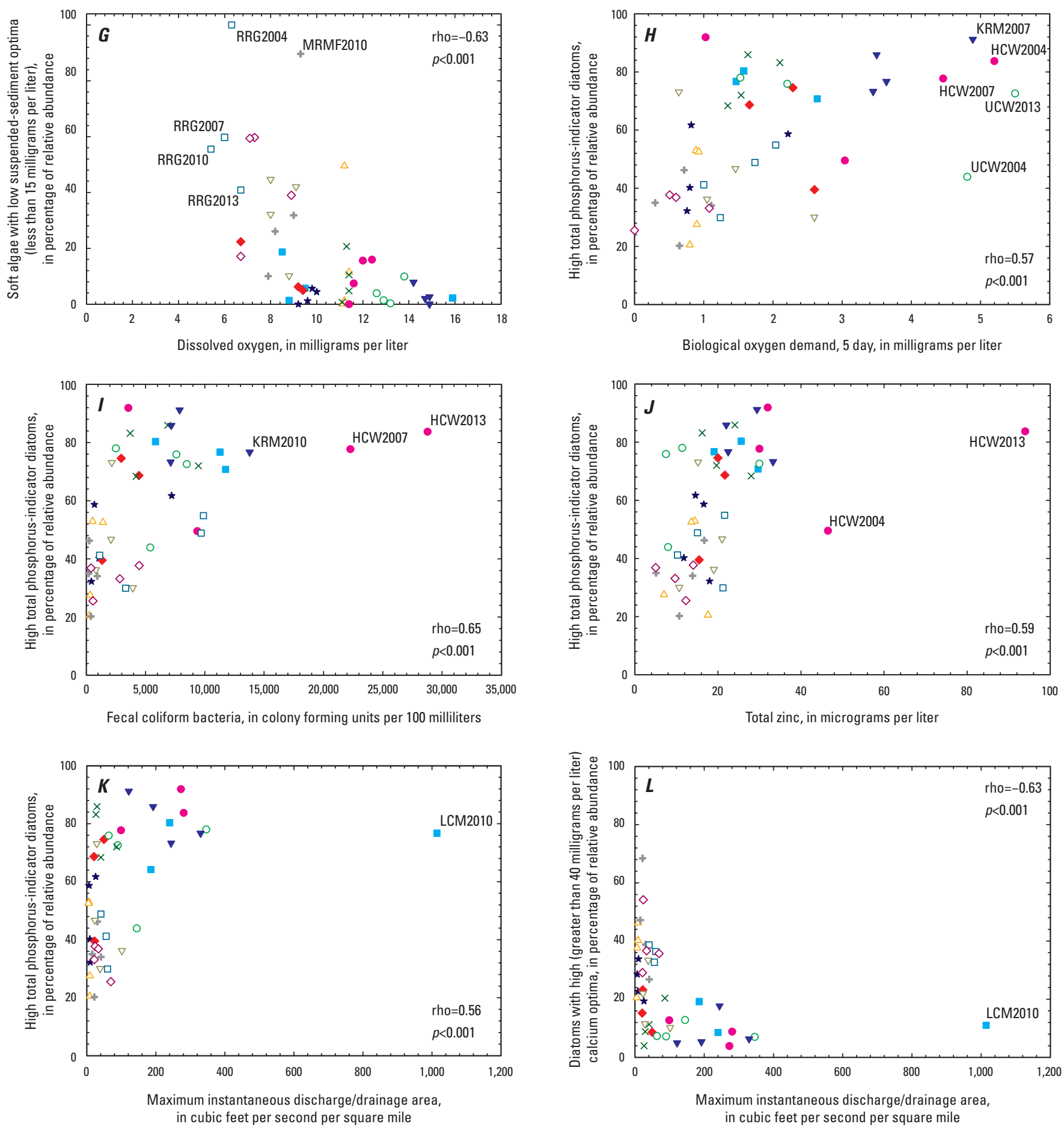

\section{EXPLANATION}

[rho, Spearman's rank correlation coefficient; $p$, probability value; <, less than; MRC, Milwaukee River near Cedarburg; LCM, Lincoln Creek at 47th Street at Milwaukee; MRM, Milwaukee River at Milwaukee; WCG, Willow Creek at Maple Road, near Germantown; MRMF, Menomonee River at Menomonee Falls; LMM, Little Menomonee River at Milwaukee; UCW, Underwood Creek at Wauwatosa; HCW, Honey Creek at Wauwatosa; MRW, Menomonee River at Wauwatosa; KRM, Kinnickinnic River at South 11th Street at Milwaukee; OCSM, Oak Creek at South Milwaukee; RRG, Root River at Grange Avenue at Greenfield; RRF, Root River near Franklin; JCM, Jewel Creek at Muskego]

$\begin{array}{lllllll}\triangle \text { MRC } & \star \text { MRM } & + \text { MRMF } & \circ \text { UCW } & \times \text { MRW } & \nabla \text { OCSM } & \diamond \text { RRF } \\ - \text { LCM } & \triangle \text { WCG } & \star \text { LMM } & \bullet \text { HCW } & \nabla \text { KRM } & \square \text { RRG } & \triangle \text { JCM }\end{array}$

Figure 11. Relations between algal metrics and environmental metrics for 14 streams in the Milwaukee area, Wisconsin, 2004-13. Environmental metrics for water quality are means for the year of ecological sampling.-Continued 

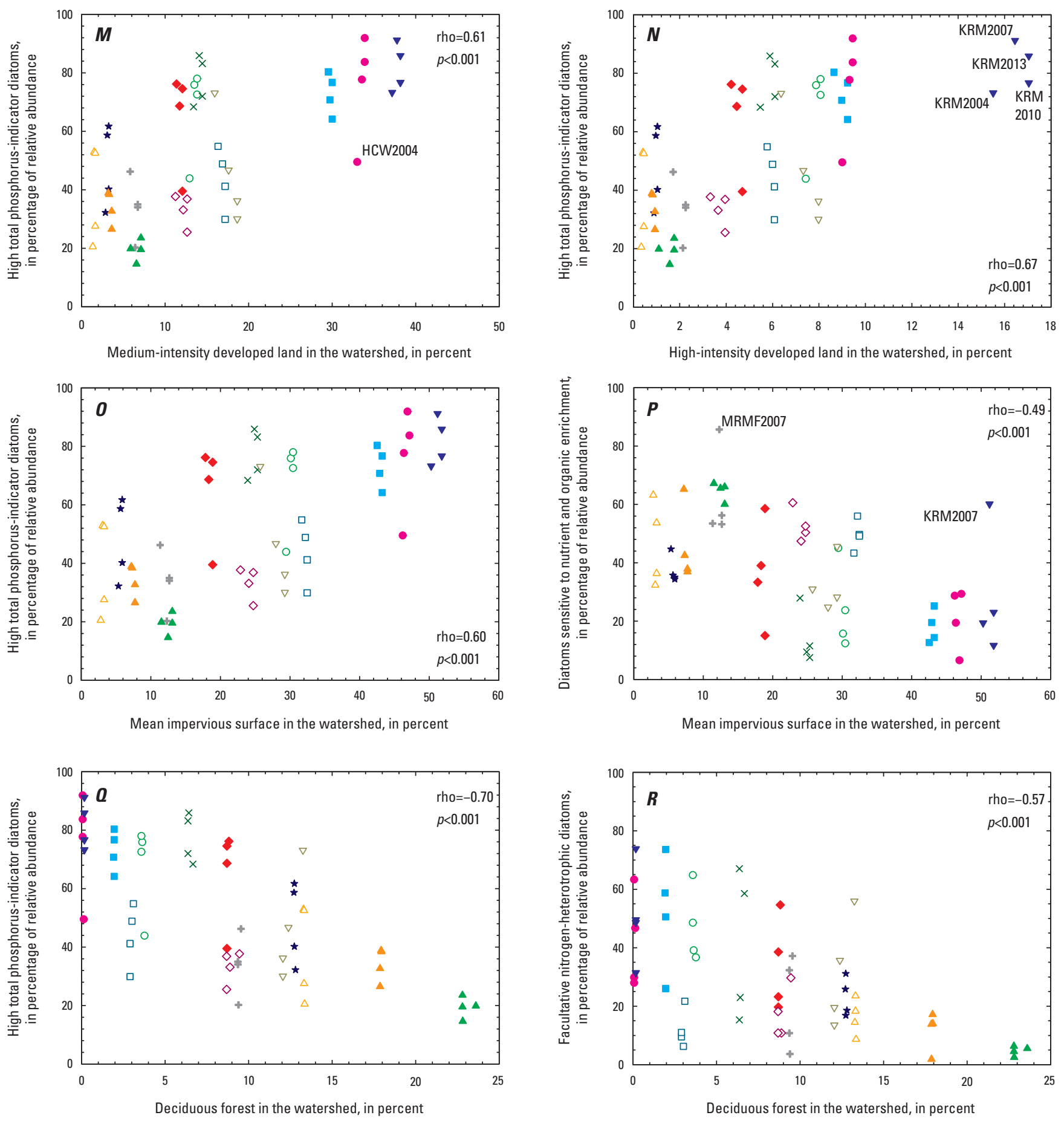

\section{EXPLANATION}

[rho, Spearman's rank correlation coefficient; $p$, probability value; <, less than; MRC, Milwaukee River near Cedarburg; LCM, Lincoln Creek at 47th Street at Milwaukee; MRM, Milwaukee River at Milwaukee; WCG, Willow Creek at Maple Road, near Germantown; MRMF, Menomonee River at Menomonee Falls; LMM, Little Menomonee River at Milwaukee; UCW, Underwood Creek at Wauwatosa; HCW, Honey Creek at Wauwatosa; MRW, Menomonee River at Wauwatosa; KRM, Kinnickinnic River at South 11th Street at Milwaukee; OCSM, Oak Creek at South Milwaukee; RRG, Root River at Grange Avenue at Greenfield; RRF, Root River near Franklin; JCM, Jewel Creek at Muskego]

$\begin{array}{lllllll}\triangle \text { MRC } & \star \text { MRM } & + \text { MRMF } & \circ \text { UCW } & \times \text { MRW } & \nabla \text { OCSM } & \diamond \text { RRF } \\ \square \text { LCM } & \triangle \text { WCG } & \diamond \text { LMM } & - \text { HCW } & \nabla \text { KRM } & \square \text { RRG } & \triangle \text { JCM }\end{array}$

Figure 11. Relations between algal metrics and environmental metrics for 14 streams in the Milwaukee area, Wisconsin, $2004-13$. Environmental metrics for water quality are means for the year of ecological sampling.-Continued 

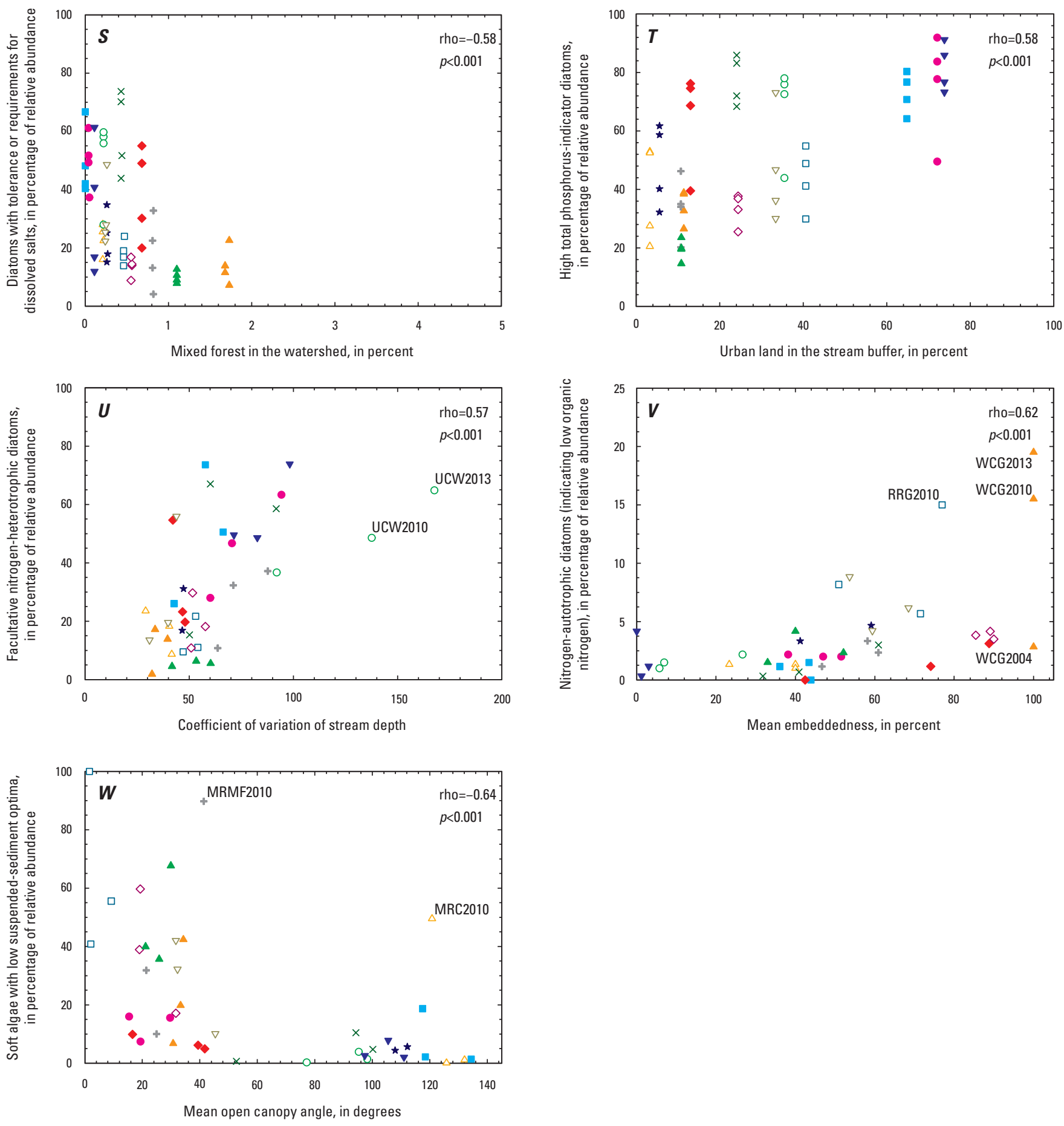

EXPLANATION

[rho, Spearman's rank correlation coefficient; $p$, probability value; <, less than; MRC, Milwaukee River near Cedarburg; LCM, Lincoln Creek at 47th Street at Milwaukee; MRM, Milwaukee River at Milwaukee; WCG, Willow Creek at Maple Road, near Germantown; MRMF, Menomonee River at Menomonee Falls; LMM, Little Menomonee River at Milwaukee; UCW, Underwood Creek at Wauwatosa; HCW, Honey Creek at Wauwatosa; MRW, Menomonee River at Wauwatosa; KRM, Kinnickinnic River at South 11th Street at Milwaukee; OCSM, Oak Creek at South Milwaukee; RRG, Root River at Grange Avenue at Greenfield; RRF, Root River near Franklin; JCM, Jewel Creek at Muskego]

$\begin{array}{lllllll}\triangle \text { MRC } & \star \text { MRM } & + \text { MRMF } & \circ \text { UCW } & \times \text { MRW } & \nabla \text { OCSM } & \diamond \text { RRF } \\ - \text { LCM } & \triangle \text { WCG } & \bullet \text { LMM } & \bullet \text { HCW } & \nabla \text { KRM } & \square \text { RRG } & \triangle \text { JCM }\end{array}$

Figure 11. Relations between algal metrics and environmental metrics for 14 streams in the Milwaukee area, Wisconsin, 2004-13. Environmental metrics for water quality are means for the year of ecological sampling.-Continued 

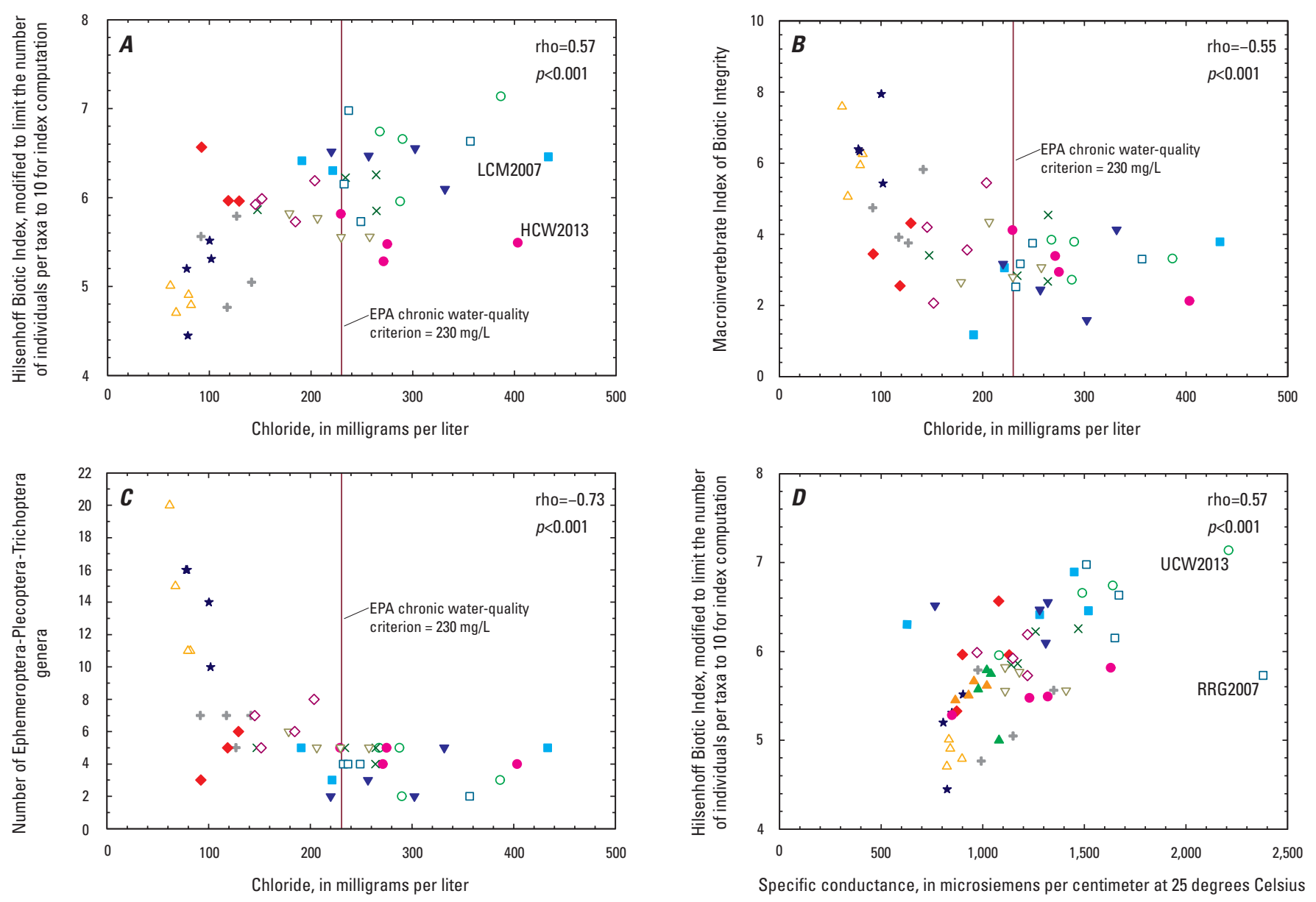

Specific conductance, in microsiemens per centimeter at 25 degrees Celsius
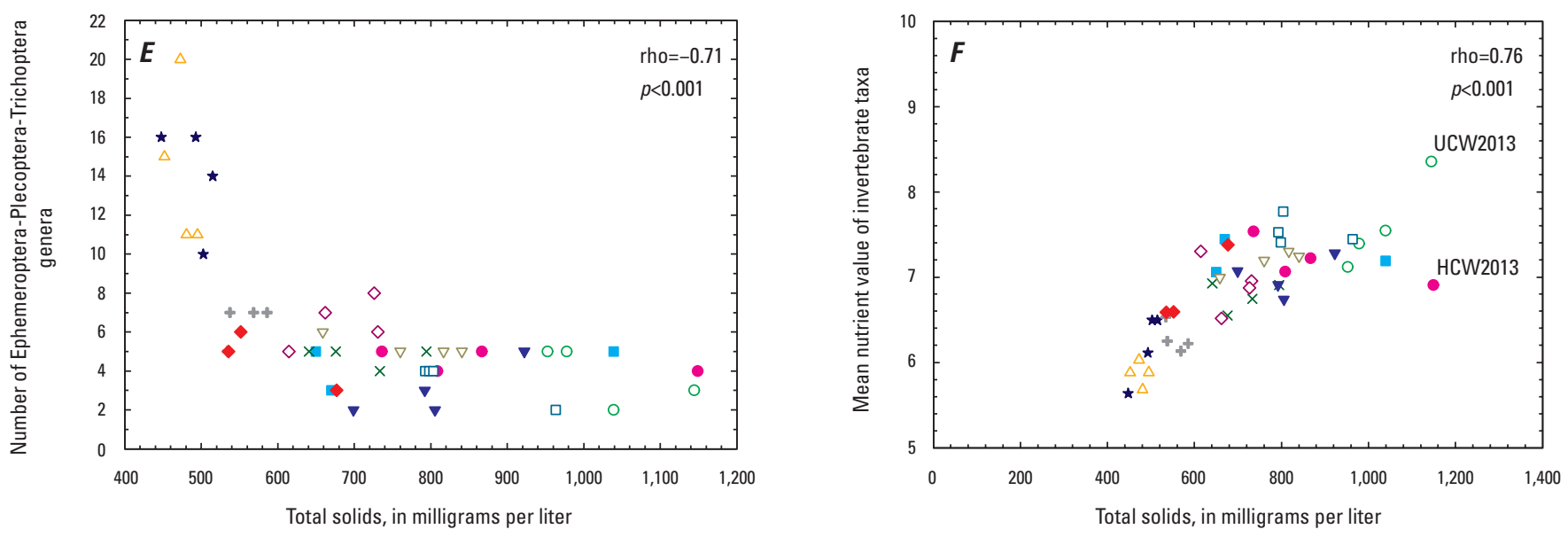

EXPLANATION

[rho, Spearman's rank correlation coefficient; $p$, probability value; <, less than; MRC, Milwaukee River near Cedarburg; LCM, Lincoln Creek at 47th Street at Milwaukee; MRM, Milwaukee River at Milwaukee; WCG, Willow Creek at Maple Road, near Germantown; MRMF, Menomonee River at Menomonee Falls; LMM, Little Menomonee River at Milwaukee; UCW, Underwood Creek at Wauwatosa; HCW, Honey Creek at Wauwatosa; MRW, Menomonee River at Wauwatosa; KRM, Kinnickinnic River at South 11th Street at Milwaukee; OCSM, Oak Creek at South Milwaukee; RRG, Root River at Grange Avenue at Greenfield; RRF, Root River near Franklin; JCM, Jewel Creek at Muskego; EPA, U.S. Environmental Protection Agency; mg/L, milligram per liter]

$\begin{array}{lllllll}\triangle \text { MRC } & \star \text { MRM } & + \text { MRMF } & \circ \text { UCW } & \times \text { MRW } & \nabla \text { OCSM } & \diamond \text { RRF } \\ \square \text { LCM } & \triangle \text { WCG } & \diamond \text { LMM } & \bullet \text { HCW } & \nabla \text { KRM } & \square \text { RRG } & \triangle \text { JCM }\end{array}$

Figure 12. Relations between invertebrate metrics and environmental metrics for 14 streams in the Milwaukee area, Wisconsin, 2004-13. Environmental metrics for water quality are means for the year of ecological sampling. 

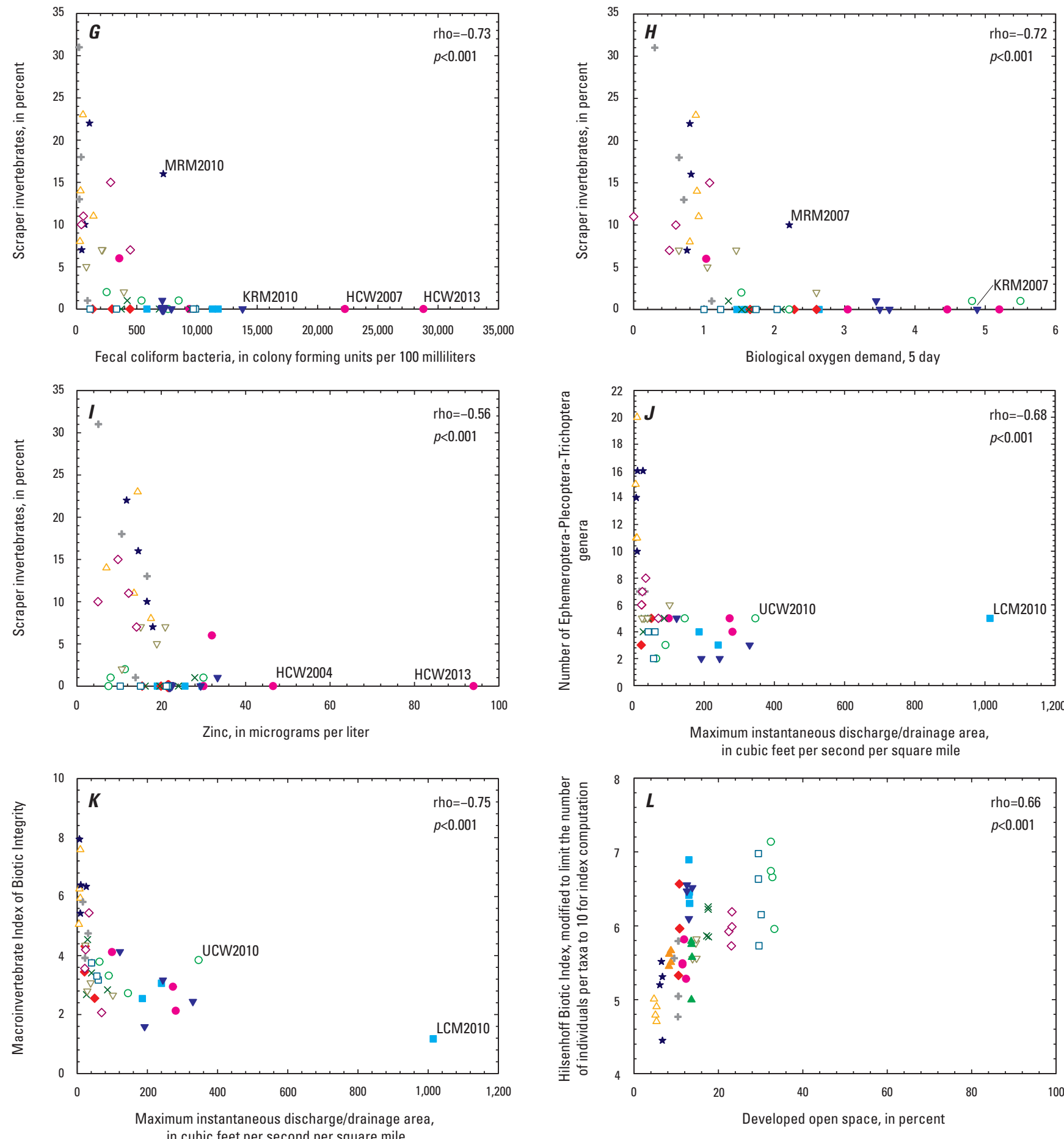

\section{EXPLANATION}

[rho, Spearman's rank correlation coefficient; $p$, probability value; <, less than; MRC, Milwaukee River near Cedarburg; LCM, Lincoln Creek at 47th Street at Milwaukee; MRM, Milwaukee River at Milwaukee; WCG, Willow Creek at Maple Road, near Germantown; MRMF, Menomonee River at Menomonee Falls; LMM, Little Menomonee River at Milwaukee; UCW, Underwood Creek at Wauwatosa; HCW, Honey Creek at Wauwatosa; MRW, Menomonee River at Wauwatosa; KRM, Kinnickinnic River at South 11th Street at Milwaukee; OCSM, Oak Creek at South Milwaukee; RRG, Root River at Grange Avenue at Greenfield; RRF, Root River near Franklin; JCM, Jewel Creek at Muskego]

$$
\begin{array}{lllllll}
\triangle \text { MRC } & \star \text { MRM } & + \text { MRMF } & \circ \text { UCW } & \times \text { MRW } & \nabla \text { OCSM } & \diamond \text { RRF } \\
\square \text { LCM } & \triangle \text { WCG } & \diamond \text { LMM } & \bullet \text { HCW } & \nabla \text { KRM } & \square \text { RRG } & \triangle \text { JCM }
\end{array}
$$

Figure 12. Relations between invertebrate metrics and environmental metrics for 14 streams in the Milwaukee area, Wisconsin, 2004-13. Environmental metrics for water quality are means for the year of ecological sampling.-Continued 

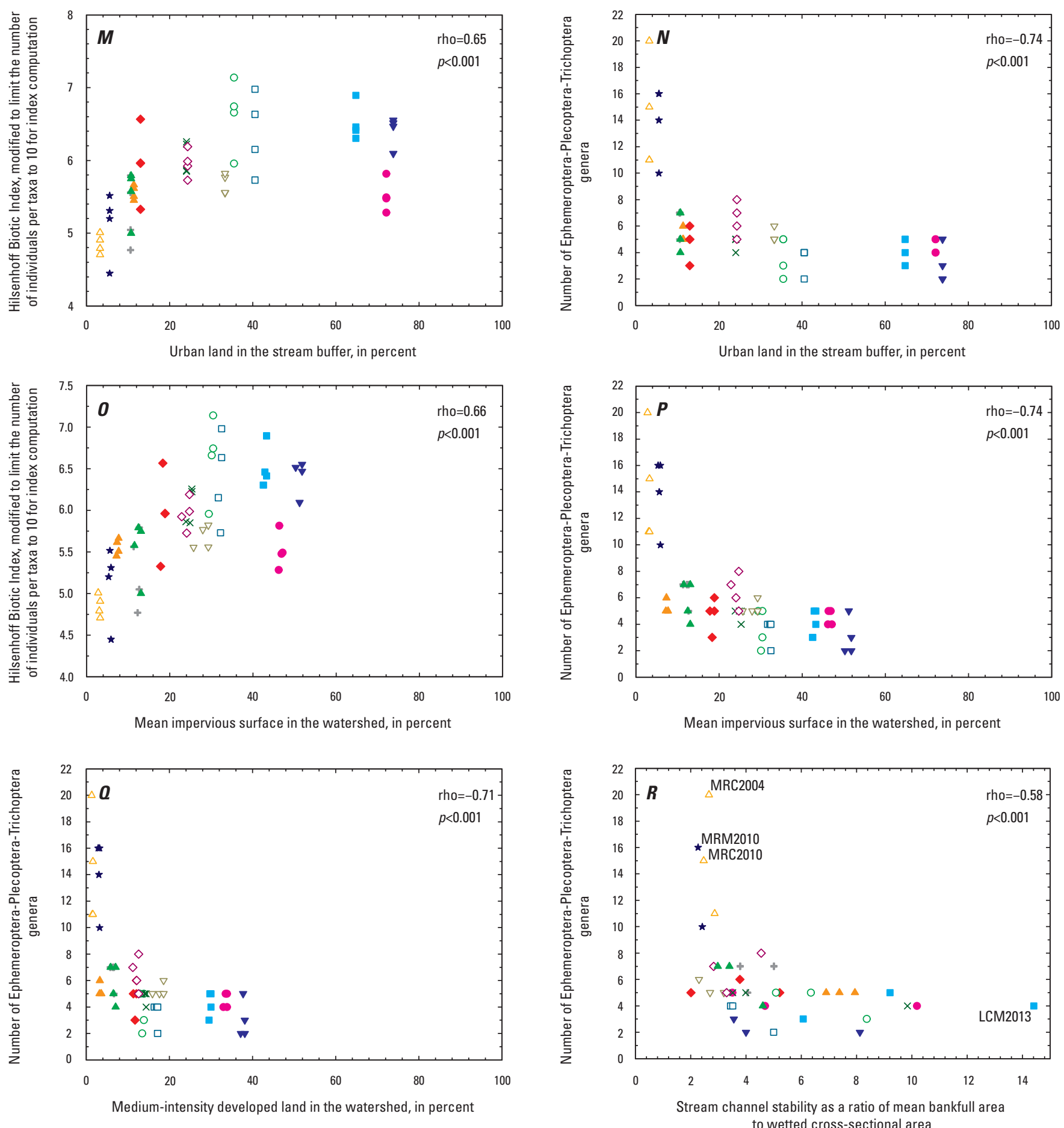

EXPLANATION

[rho, Spearman's rank correlation coefficient; $p$, probability value; <, less than; MRC, Milwaukee River near Cedarburg; LCM, Lincoln Creek at 47th Street at Milwaukee; MRM, Milwaukee River at Milwaukee; WCG, Willow Creek at Maple Road, near Germantown; MRMF, Menomonee River at Menomonee Falls; LMM, Little Menomonee River at Milwaukee; UCW, Underwood Creek at Wauwatosa; HCW, Honey Creek at Wauwatosa; MRW, Menomonee River at Wauwatosa; KRM, Kinnickinnic River at South 11th Street at Milwaukee; OCSM, Oak Creek at South Milwaukee; RRG, Root River at Grange Avenue at Greenfield; RRF, Root River near Franklin; JCM, Jewel Creek at Muskego]

$$
\begin{array}{lllllll}
\triangle \text { MRC } & \star \text { MRM } & + \text { MRMF } & \circ \text { UCW } & \times \text { MRW } & \nabla \text { OCSM } & \diamond \text { RRF } \\
\square \text { LCM } & \triangle \text { WCG } & \text { LMM } & \bullet \text { HCW } & \nabla \text { KRM } & \square \text { RRG } & \triangle \text { JCM }
\end{array}
$$

Figure 12. Relations between invertebrate metrics and environmental metrics for 14 streams in the Milwaukee area, Wisconsin, 2004-13. Environmental metrics for water quality are means for the year of ecological sampling.-Continued 

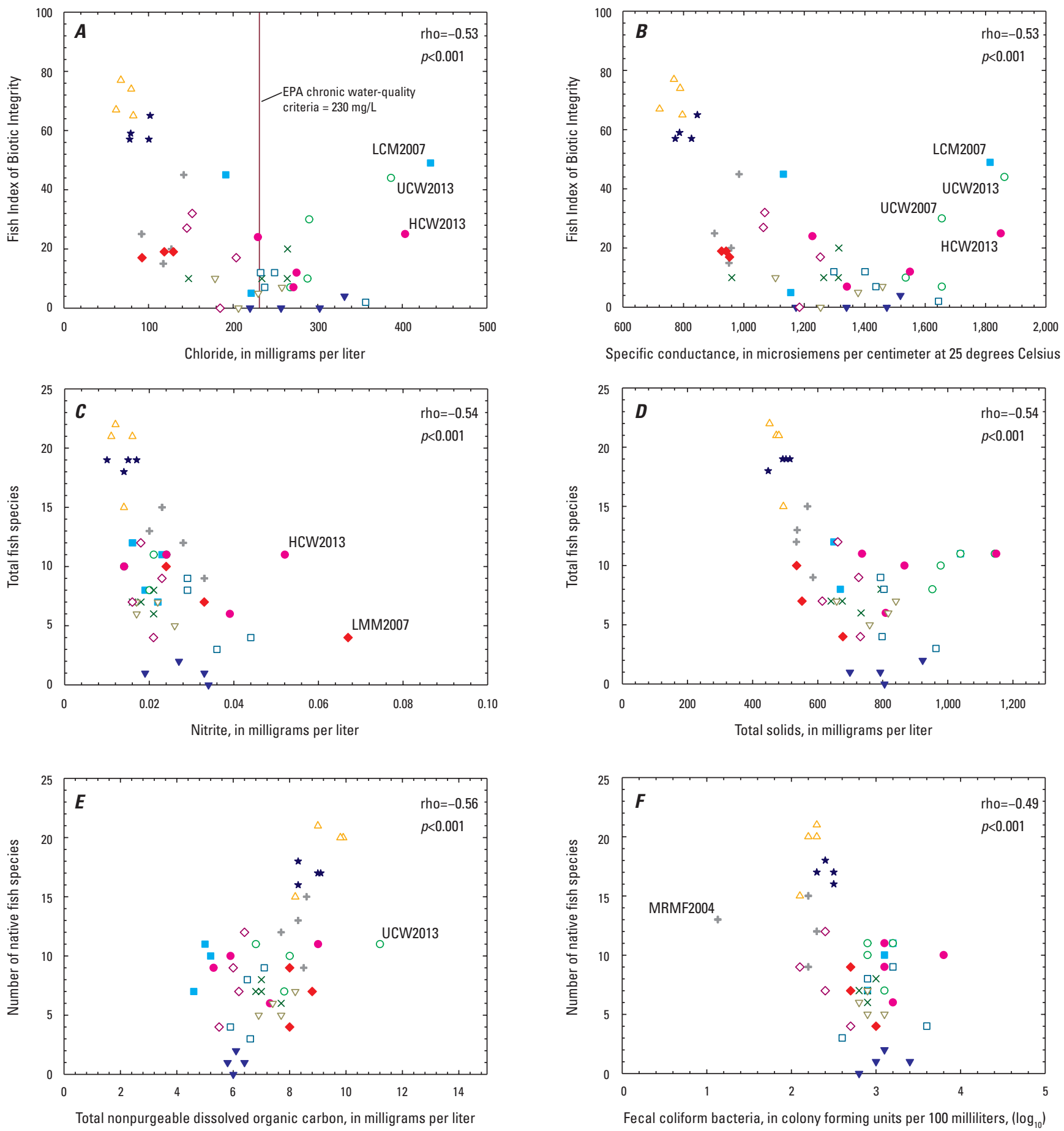

EXPLANATION

[rho, Spearman's rank correlation coefficient; $p$, probability value; <, less than; MRC, Milwaukee River near Cedarburg; LCM, Lincoln Creek at 47th Street at Milwaukee; MRM, Milwaukee River at Milwaukee; WCG, Willow Creek at Maple Road, near Germantown; MRMF, Menomonee River at Menomonee Falls; LMM, Little Menomonee River at Milwaukee; UCW, Underwood Creek at Wauwatosa; HCW, Honey Creek at Wauwatosa; MRW, Menomonee River at Wauwatosa; KRM, Kinnickinnic River at South 11th Street at Milwaukee; OCSM, Oak Creek at South Milwaukee; RRG, Root River at Grange Avenue at Greenfield; RRF, Root River near Franklin; JCM, Jewel Creek at Muskego; EPA, U.S. Environmental Protection Agency; mg/L, milligram per liter]

$\begin{array}{lllllll}\triangle \text { MRC } & \star \text { MRM } & + \text { MRMF } & \circ \text { UCW } & \times \text { MRW } & \nabla \text { OCSM } & \diamond \text { RRF } \\ \square \text { LCM } & \triangle \text { WCG } & \diamond \text { LMM } & \bullet \text { HCW } & \nabla \text { KRM } & \square \text { RRG } & \triangle \text { JCM }\end{array}$

Figure 13. Relations between fish metrics and environmental metrics for 14 streams in the Milwaukee area, Wisconsin, 2004-13. Environmental metrics for water quality are means for the year of ecological sampling. 

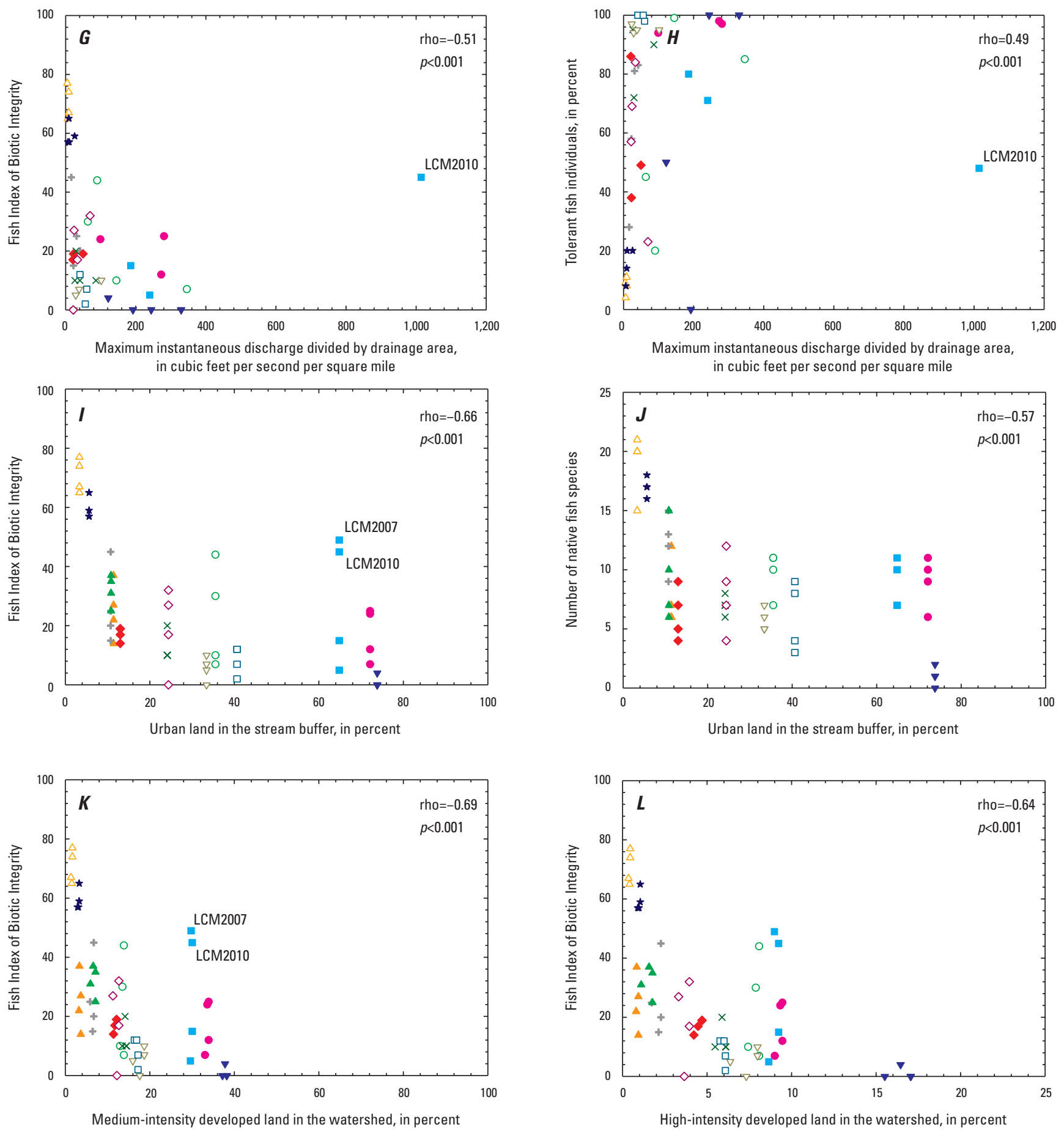

EXPLANATION

[rho, Spearman's rank correlation coefficient; $p$, probability value; <, less than; MRC, Milwaukee River near Cedarburg; LCM, Lincoln Creek at 47th Street at Milwaukee; MRM, Milwaukee River at Milwaukee; WCG, Willow Creek at Maple Road, near Germantown; MRMF, Menomonee River at Menomonee Falls; LMM, Little Menomonee River at Milwaukee; UCW, Underwood Creek at Wauwatosa; HCW, Honey Creek at Wauwatosa; MRW, Menomonee River at Wauwatosa; KRM, Kinnickinnic River at South 11th Street at Milwaukee; OCSM, Oak Creek at South Milwaukee; RRG, Root River at Grange Avenue at Greenfield; RRF, Root River near Franklin; JCM, Jewel Creek at Muskego]

$\begin{array}{lllllll}\triangle \text { MRC } & \star \text { MRM } & + \text { MRMF } & \circ \text { UCW } & \times \text { MRW } & \nabla \text { OCSM } & \diamond \text { RRF } \\ \square \text { LCM } & \triangle \text { WCG } & \text { LMM } & \bullet \text { HCW } & \nabla \text { KRM } & \square \text { RRG } & \triangle \text { JCM }\end{array}$

Figure 13. Relations between fish metrics and environmental metrics for 14 streams in the Milwaukee area, Wisconsin, $2004-13$. Environmental metrics for water quality are means for the year of ecological sampling.-Continued 

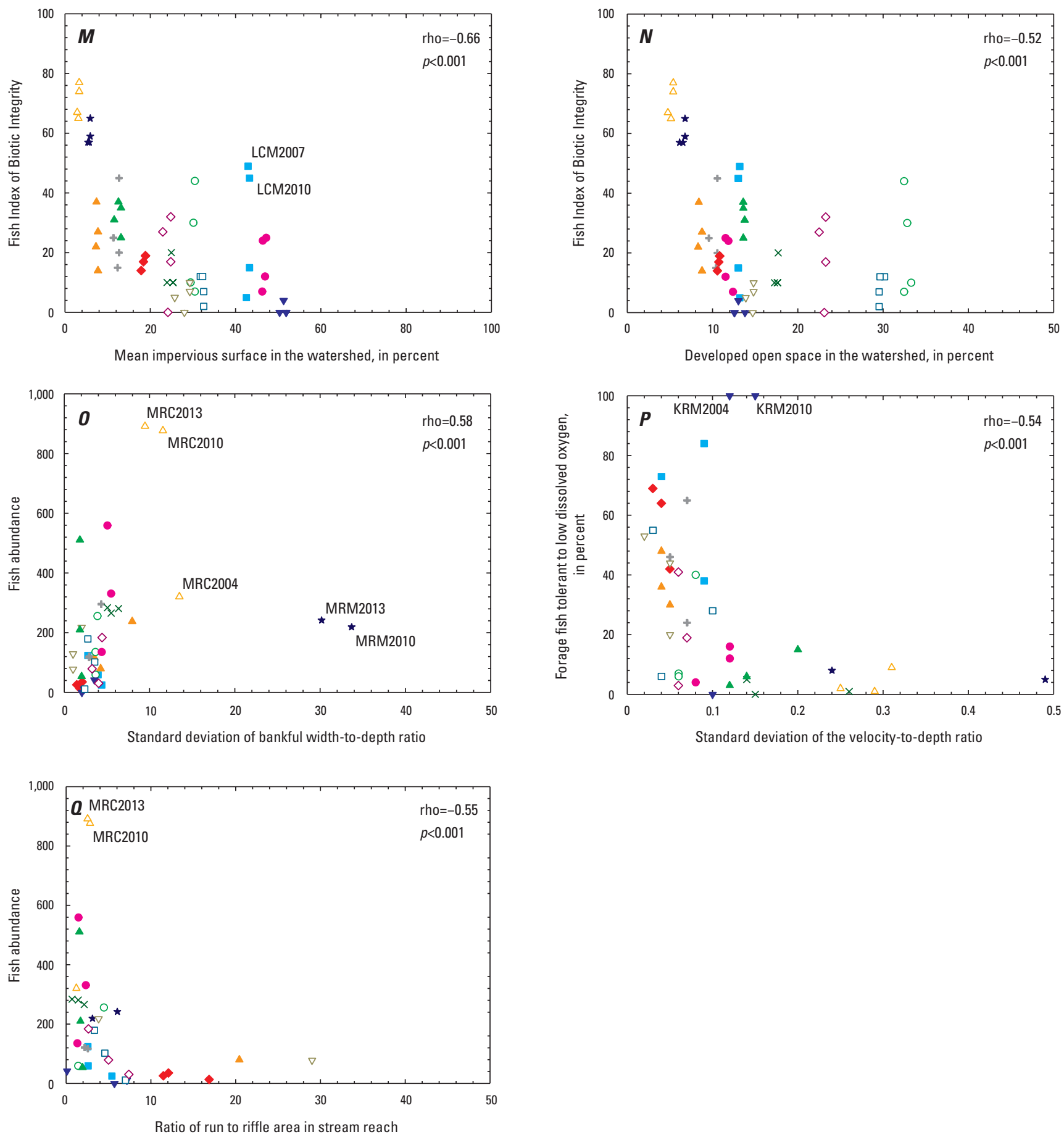

\section{EXPLANATION}

[rho, Spearman's rank correlation coefficient; $p$, probability value; <, less than; MRC, Milwaukee River near Cedarburg; LCM, Lincoln Creek at 47th Street at Milwaukee; MRM, Milwaukee River at Milwaukee; WCG, Willow Creek at Maple Road, near Germantown; MRMF, Menomonee River at Menomonee Falls; LMM, Little Menomonee River at Milwaukee; UCW, Underwood Creek at Wauwatosa; HCW, Honey Creek at Wauwatosa; MRW, Menomonee River at Wauwatosa; KRM, Kinnickinnic River at South 11th Street at Milwaukee; OCSM, Oak Creek at South Milwaukee; RRG, Root River at Grange Avenue at Greenfield; RRF, Root River near Franklin; JCM, Jewel Creek at Muskego]

$\begin{array}{lllllll}\triangle \text { MRC } & \star \text { MRM } & + \text { MRMF } & \circ \text { UCW } & \times \text { MRW } & \nabla \text { OCSM } & \diamond \text { RRF } \\ =\text { LCM } & \triangle \text { WCG } & \bullet \text { LMM } & \bullet \text { HCW } & \nabla \text { KRM } & \square \text { RRG } & \triangle \text { JCM }\end{array}$

Figure 13. Relations between fish metrics and environmental metrics for 14 streams in the Milwaukee area, Wisconsin, 2004-13. Environmental metrics for water quality are means for the year of ecological sampling.-Continued 
Table 10. Summary of environmental metrics correlated to metrics for algae, invertebrates, and (or) fish in streams of the Milwaukee Metropolitan Sewerage District planning area of Wisconsin, 2004-13.

[X, metric was present; --, metric was not present]

\begin{tabular}{|c|c|c|c|}
\hline Environmental metric & Algae & Invertebrates & Fish \\
\hline Fecal coliform bacteria & $\mathrm{X}$ & $\mathrm{X}$ & $\mathrm{X}$ \\
\hline Biological oxygen demand, 5 day & $\mathrm{X}$ & $\mathrm{X}$ & -- \\
\hline Dissolved oxygen & $\mathrm{X}$ & -- & -- \\
\hline Ammonia nitrogen & $\mathrm{X}$ & -- & -- \\
\hline Total nonpurgeable inorganic carbon & $\mathrm{X}$ & -- & -- \\
\hline Total nonpurgeable dissolved organic carbon & -- & -- & $\mathrm{X}$ \\
\hline Chloride & -- & $\mathrm{X}$ & $\mathrm{X}$ \\
\hline Specific conductance & -- & $\mathrm{X}$ & $\mathrm{X}$ \\
\hline Nitrite & -- & -- & $\mathrm{X}$ \\
\hline Zinc & $\mathrm{X}$ & $\mathrm{X}$ & -- \\
\hline Total solids & -- & $\mathrm{x}$ & $\mathrm{X}$ \\
\hline Maximum instantaneous discharge/drainage area & $\mathrm{X}$ & $\mathrm{X}$ & $\mathrm{X}$ \\
\hline Developed open space & -- & $\mathrm{x}$ & $\mathrm{X}$ \\
\hline Low-intensity developed land & -- & -- & $\mathrm{X}$ \\
\hline Medium-intensity developed land & $\mathrm{X}$ & $\mathrm{X}$ & $\mathrm{X}$ \\
\hline High-intensity developed land & $\mathrm{X}$ & $\mathrm{X}$ & $\mathrm{X}$ \\
\hline Urban land in the stream buffer & $\mathrm{X}$ & $\mathrm{X}$ & $\mathrm{X}$ \\
\hline Impervious surface in the watershed & $\mathrm{X}$ & $\mathrm{X}$ & $\mathrm{X}$ \\
\hline Deciduous forest & $\mathrm{X}$ & -- & -- \\
\hline Mixed forest & $\mathrm{X}$ & -- & -- \\
\hline Stream open canopy angle & $\mathrm{X}$ & -- & -- \\
\hline Coefficient of variation of stream depth & $\mathrm{X}$ & -- & -- \\
\hline Standard deviation of the bankfull width-to-depth ratio & -- & -- & $\mathrm{X}$ \\
\hline Standard deviation of the velocity-to-depth ratio & -- & -- & $\mathrm{X}$ \\
\hline Stream channel stability & -- & $\mathrm{X}$ & -- \\
\hline Stream run-to-riffle ratio & -- & -- & $\mathrm{X}$ \\
\hline Stream substrate embeddedness & $\mathrm{X}$ & -- & -- \\
\hline
\end{tabular}

concentrations of organically bound nitrogen $(p<0.001$; fig. $11 \mathrm{~V})$; however, Willow Creek ranked as the most embedded because it is all sand and is a small stream with low productivity. Lastly, as the mean canopy angle of vegetation over the stream increased, the abundance of soft algae with low suspended-sediment optima decreased significantly, especially for canopy angles greater than about 36 degrees $(p<0.001$; fig. $11 \mathrm{~W}$ ). In 2010, the Milwaukee River near Cedarburg site was an anomaly for having high mean open canopy angles without also having a low abundance of this soft algal group.

\section{Invertebrates}

The invertebrate metrics that correlated most with environmental stressors included the number of EPT genera, HBI-10, mIBI, percentage of scraper invertebrates, and mean nutrient tolerance of invertebrate taxa. Scraper invertebrates graze on algae and associated material attached to submerged surfaces such as rocks, and this feeding group includes some mayflies, caddisflies, and other insects (Merritt and Cummins, 1996). Although all scrapers are not necessarily indicators of good water quality, many are and some (mayflies and caddisflies) are also included in EPT metrics.

For water quality, higher mean chloride concentrations in water at stream sites were significantly correlated to higher HBI-10 ratings, lower mIBI scores, and lower EPT genera values ( $p<0.001$; fig. $12 A-C$ ). These results indicate degrading invertebrate assemblages with increasing chloride concentrations. The invertebrate salinity index (Williams and others, 2000) did not correlate significantly with chloride in water (rho $=-0.33$, graph was inconclusive because of many values at 10 , the maximum value), nor did it correlate significantly with other environmental variables. The narrow range 
of Chloride Contamination Index scores at sites in our study (scores ranged from 8 to 10 ), reflecting generally salt-tolerant taxa at all sites, may have made it difficult to detect a significant relation. Mean chloride concentrations were greater than $230 \mathrm{mg} / \mathrm{L}$, the EPA chronic water-quality criterion for protection of aquatic life (U.S. Environmental Protection Agency, 1988), in one or more sampling years at several sites (Lincoln Creek [2007], Underwood Creek and Honey Creek [2004-13], Menomonee River at Wauwatosa [2007, 2013], Kinnickinnic River [2007-13], Oak Creek [2004, 2013], and Root River at Greenfield [2004-13]). Trends in increasing chloride concentrations of streams in all seasons as a result of road salt were reported in the literature for urban areas of the northern United States where salt is used to deice roads and parking lots (Judd, 1970; Corsi and others, 2010, 2015). Corsi and others (2015) determined that stream chloride concentrations increased in 13 Milwaukee area streams from 1980 to 2010, including 11 of the 14 streams sampled in the current study. At only about 10-percent impervious surface (about 25-percent urban land), chloride concentrations began to exceed the criterion. Specific conductance, in microsiemens per centimeter at 25 degrees Celsius, measured on the day of biological sampling, a useful surrogate measure for chloride and other major ions, also correlated positively with chloride $(\mathrm{rho}=0.68)$ and the HBI-10 (rho=0.57) $(p<0.001$; fig. 12D). The advantage of using specific conductance is that it can be more simply measured than chloride using a multiparameter sonde to provide instantaneous values during sampling. Chloride concentrations increased strongly with the percentage of urban land in the stream buffer $(r h o=0.82)$ and with the percentages of low, medium, and high-intensity urban land in the watershed (rho $>0.77$ ). Other chemical metrics that demonstrated significant negative correlations with invertebrate metrics were total solids (which were positively correlated with impervious surface [rho=0.98; not shown]), fecal coliform bacteria, BOD5, and zinc, an indicator of urban runoff ( $p<0.001$; fig. 12E- $)$. Lastly, higher values of the maximum instantaneous discharge during the year of biological sampling, normalized by drainage area, were significantly related to lower numbers of EPT genera and mIBI scores ( $p<0.001$; fig. $12 J-K$ ), especially for normalized discharge values greater than 40 cubic feet per second per square mile.

Percentages of developed open space, urban land in the stream buffer, mean impervious surface in the watershed, and medium-intensity developed (urban) land in the watershed all demonstrated significant adverse relations with the HBI-10 or number of EPT genera $(p<0.001$; fig. $12 L-Q)$. Richards and others (2010) determined significant positive correlations between chloride and several urban-related land-use/landcover metrics, especially the percentage of impervious surface in the watershed, urban land, and road coverage. Urban land in the stream buffer reduces the ability of natural vegetation and uncompacted soil surfaces to absorb rainfall in significant amounts and thereby increases the amount of runoff (Roy and others, 2006).
Channel stability (the ratio of mean bankfull area to wetted cross-sectional area) correlated negatively with the number of EPT genera, and this was the only instream habitat variable that correlated significantly with computed invertebrate metrics ( $p<0.001$; fig. $12 R$ ). This metric potentially represents the possible intensity of flood discharge relative to base flow (perennial discharge), and high values represent channels prone to erosion. So, in essence, less stable channels were related to fewer EPT taxa, which is an adverse effect. Perhaps the controlling factor for the invertebrate assemblages is not velocity during low flow but instead flashiness and the relation of floods to channel substrates. For microhabitat data - data for the algal and invertebrate sampling subsites such as depth, velocity, and dominant substrate - only depth correlated significantly to metrics computed for invertebrates in the current study. Although the relation demonstrated poor predictability, HBI-10 values indicated a wedge-shaped distribution with microhabitat depth, such that better HBI-10 ratings were more likely to be associated with greater riffle depth $(p<0.01)$. The reason for the weak or missing relations to microhabitat is not clear but it may be due to a general lack of variability in microhabitat because shallow cobble riffles were targeted for invertebrate sampling at all sites except Willow Creek, where they were not available. Still, mean velocity of the reach correlated positively with microhabitat velocity $(p<0.001)$.

\section{Fish}

The IBI was the fish metric most commonly correlated with the environmental metrics, likely because it is composed of 10 fish metrics that were selected by Lyons (1992) because they are useful in distinguishing differences in the environmental quality of streams. The IBI developed by Lyons (1992) is the fish IBI used for warmwater streams in the State of Wisconsin. Related fish metrics that also correlated to environmental metrics were the number of fish (abundance), number of species (richness), number of native taxa, and fish tolerant to low DO. Correlations with fish metrics were determined for metrics related to water quality, discharge, land use/land cover, and stream habitat (fig. 13).

Fish assemblage metrics related to water quality and discharge in a variety of ways. Higher mean chloride concentration and specific conductance correlated significantly to lower fish IBI values ( $p<0.001$; fig. $13 A-B)$, similar to the adverse response of invertebrates to chloride and specific conductance. Declines in fish IBI scores in relation to increasing chloride and specific conductance could be the result of direct effects upon the fish by physiological changes, such as osmoregulation, and indirect effects, such as from a decline in invertebrate food sources. Nutrient effects on fish were also seen. As mean nitrite concentrations increased in water, the number of fish species decreased significantly as a wedgeshaped or factor-ceiling distribution ( $p<0.001$; fig. 13C). Nitrite and ammonia are known to be toxic to fish; however, nitrite concentrations are generally low in natural waters unless the process of microorganisms converting ammonia to 
nitrite and then to nitrate is disrupted (Russo and Thurston, 1977). Significant correlations to fish metrics were not determined for phosphorus. The number of fish species decreased as total solids increased, a correlation similar to that seen with invertebrates $(p<0.001$; fig. $13 D)$. Although higher concentrations of total nonpurgeable dissolved organic carbon correlated significantly to higher abundances of native fish species $(p<0.001$; fig. $13 E)$, this relation is probably an artifact of the two main-stem Milwaukee River sites (Milwaukee River near Cedarburg and Milwaukee River at Milwaukee), which have more species. The highest and second highest dissolved organic carbon values were for these sites. These two large river sites would be expected to have more native species than streams that are much smaller in drainage area. In addition, the number of native fish species decreased with increasing fecal coliform bacteria across sampled sites ( $p<0.001$; fig. $13 F$ ). Higher values of maximum instantaneous discharge during the year of biological sampling, normalized by drainage area, were significantly correlated to lower IBI scores and more tolerant fish ( $p<0.001$; fig. 13G-H), and fewer native fish species $(p<0.001)$. The correlation with maximum instantaneous discharge indicates that more frequent flood and scour effects from high flows at some sampled streams, a common problem with streams subject to urban runoff, can adversely affect fish assemblages.

More urban land in the stream buffer and higher percentages of the watershed as medium and high-intensity developed land, developed open space, and impervious surface correlated significantly to lower fish IBI values and fewer native fish species $(p<0.001$; fig. $13 I-N)$. Similar to land-cover correlations determined with algae and invertebrates, these results underscore the adverse effects of increased urban land on the aquatic communities of nearby waterways.

Instream habitat metrics that correlated to fish metrics were related to stream depth and the amount of riffle habitat. As expected, higher fish abundance corresponded to more available habitat as measured by the standard deviation of the bankfull width-to-depth ratio, with the exception of the Milwaukee River at Milwaukee site in 2010 and 2013 where fish abundance was lower than expected and lower than in 2004 and 2007 ( $p<0.001$; fig. 13O). The reason for the lower fish abundance is not known but, in 2010, the flow was higher than in prior sampling events with turbid conditions, the current was swift in some areas, and no fish were captured in seine hauls. This was also the first year that the invasive Neogobius melanostomus (round goby) was detected at this site. Higher percentages of forage fish tolerant to low DO were more likely at sites with a lower standard deviation in the velocity-to-depth ratio (Lincoln Creek, Willow Creek, Menomonee River at Menomonee Falls, Little Menomonee River, and Kinnickinnic River) when compared to sites with a higher standard deviation in the velocity-to-depth ratio (Milwaukee River near Cedarburg, Milwaukee River at Milwaukee, Menomonee River at Wauwatosa, Honey Creek, and Jewel Creek; $p<0.001$; fig. 13P). A lower standard deviation relates to less variability and may therefore reflect less "complexity" in velocity-to-depth combinations and fewer types of habitat for fish. In general, fish abundance was higher at sites where the ratio of run to riffle area was lower, meaning that the riffle area was greater than the run area $(p<0.001$; fig. $13 Q$ ). Channelization of a stream generally is done by increasing the depth and straightening the channel uniformly (Hohensinner and others, 2018). Riffles are usually an indication that habitat overall has not been degraded by channelization or sedimentation, whereas more runs are an indication that a stream is channelized and lacks habitat complexity. Riffles play an important role in the production of food, and DO in stream sections is key to healthy fish assemblages (Simonson and others, 1993).

\section{Summary Bioassessments of Individual Streams}

In this section, we consider each stream individually, summarize how each group of biota has fared in the years from 2004 to 2013, and attempt to relate measured environmental stressors to any changes over time. Where possible, assessment results in one group of organisms are compared with results for another group to confirm or contradict the overall ecological assessment of the stream. This summary is not meant to provide a comprehensive, general background on each stream or river because such information is readily available in other publications. Instead, the focus is on the aquatic communities and possible changes in their status.

\section{Milwaukee River near Cedarburg}

This site has remained at the top of the aggregate bioassessment rankings in 2004 and 2013, reflecting its overall good condition and diverse aquatic habitat (table 8). For algae, three phyla (diatoms and green and blue-green algae) were collected in 2004; these three phyla were collected in 2013 also, with the addition of red algae in 2010 (table 3). Biovolume was several orders of magnitude higher in 2013 than 2004. This site had more than 1.7 times the biovolume in 2013 compared with other sites, and this held true for all years with the exception of Jewel Creek in 2013, where total biovolume was similar to Milwaukee River near Cedarburg (table 2). Algal diversity improved from high stress (diversity index <1.5) in 2004 to moderate stress in 2013 (table 2). The percentage of relative abundance of eutrophic diatoms in 2013 was greater than 10 percent higher than in 2004, and relative abundance of diatoms in 2013 was about 10 percent lower than in 2004 (table 3). The higher overall algal biovolume, the lower relative abundance of diatoms, and the greater relative abundance of eutrophic diatoms indicate adverse changes in the algal assemblage, in contrast with higher diversity metrics noted in 2013 compared with 2004. Higher diversity with adverse indicators may occur if additional taxa and abundance stem from nuisance algae. Environmental explanations related to these results are unclear; however, water chemistry data 
demonstrated that mean Escherichia coli and fecal coliform bacteria counts were unusually high for this site in 2010 but not in 2013 though nutrients were consistent across years.

The invertebrate assemblage at this main-stem site includes diverse and abundant aquatic insect larvae and freshwater mussels. Although the percentage of noninsects increased slightly from 0.77 percent in 2004 to 2.06 percent in 2013, this was because freshwater mussels were collected in 2013 but not in 2004 (table 5). Freshwater mussels are indicators of good water quality that are not adequately sampled by our collection methods because of the highly patchy nature of these organisms. Although the percentage of EPT taxa and the HBI-10 were relatively constant over the sampling years, diversity and the mIBI were lower in 2013 (5.94, "fair") compared with 2004 (7.59, "good"). Genera richness and EPT genera were highest in 2004 and lowest in 2013 (fig. 6A). These results, although somewhat conflicting, may indicate adverse changes in the invertebrate assemblage at this site.

There were no discernable changes in the fish assemblage during 2004-13 at the site. The site is a scenic, meandering stream that supports a diverse variety of fish species, including desirable game fish such as Micropterus dolomieu (smallmouth bass), Esox lucius (northern pike), and pan fish. Of the 48 fish species collected in the greater MMSD area during the study, 29 were detected at the Milwaukee River near Cedarburg site, the highest richness at any site. The IBI scores have consistently been the highest of all sampling sites in the study area (table 7, fig. 9A). For richness, 21 species were collected in 2013, compared with 22 in 2010 and 21 in 2004. In 2007, severe weather restricted electrofishing and the crew was unable to complete more than a single pass of the reach. The number of species (15) and individual fish collected reflect that not all habitats were thoroughly sampled that year. Oddly, diversity was about 27 percent lower in 2013 (1.91) than in 2004 (2.61). On July 20, 2016, the sampling crew detected 60 invasive round gobies, which we believe is a first for this site. It is not clear how this new invader will affect the assemblage going forward in future assessments of ecosystem condition.

Environmental stressors at the Milwaukee River near Cedarburg site are currently few but runoff from urban and agricultural land is a concern in addition to invasive species. As mentioned earlier, toxicity tests from SPMDs indicated some potential toxicity from hydrophobic organic compounds such as PCBs, PAHs, and so on, but PAH screening indicated low concentrations of pyrene in 2007 and 2013 and moderate concentrations in 2010 (table 9). However, Thomas and others (2007) noted moderately high PCBs in 2004-5 that may have originated from a PCB-contaminated site on Cedar Creek, which joins the Milwaukee River upstream from the sample site (for information about the Cedar Creek site, see U.S. Environmental Protection Agency, 2014). Although Baldwin and others (2013) determined that the Milwaukee River near Cedarburg during 2006-9 was one of two sites with the lowest detection frequencies and concentrations of organic waste compounds, at least 80 percent of stormflow samples had detections of PAHs, plasticizers, solvents, herbicides, insecticides, flavors/fragrances, and steroids. In the same study for a larger suite of organic waste compounds, detection frequencies in porewater samples were also 80 percent or greater. In the current study, mean specific conductance was similar for all ecological sampling years but was lowest in 2004 at 721 microsiemens per centimeter at 25 degrees Celsius $(\mu \mathrm{S} /$ $\mathrm{cm}$ at $25^{\circ} \mathrm{C}$ ). Although the mean chloride concentration of $79.6 \mathrm{mg} / \mathrm{L}$ in 2013 was low relative to other sites, chloride was 29 percent higher than in $2004(61.7 \mathrm{mg} / \mathrm{L})$. Values for maximum instantaneous discharge were similar between 2013 and 2004, indicating no difference between the two years with regard to scour from flooding; even in 2010 when other streams in the Milwaukee area experienced significant flooding, this metric was relatively low compared with the downstream site at Estabrook Park in Milwaukee. In general, water quality at this site seems good, but there are some potential environmental stressors on the aquatic community and cause for concern.

\section{Lincoln Creek}

Mean bioassessment rankings for Lincoln Creek were relatively consistent across algae, invertebrates, and fish assemblages in 2013, placing this site with the lowest water-quality sites in group 4, although the aggregate ranking in 2013 was slightly better than in 2004 (table 8). Algal assemblages at Lincoln Creek included three phyla (diatoms and green and blue-green algae) in 2004 and 2013, and the percentage of relative abundance of blue-green algae was more than 10 percent lower in 2013 compared with 2004 (table 3). Algal biovolume was also lower in 2013 than in 2004 (table 2). Pollutiontolerant diatom abundance in 2013 was about 18 percent higher compared with 2004. Pollution-sensitive diatom abundance also increased by about 13 percent from 2004 to 2013; however, there were less than 30-percent pollutionsensitive diatoms in 2013 at this site. Diversity improved from high stress (diversity index $<1.5$ ) in 2004 to moderate stress (diversity index 1.50-2.50) in 2013. The percentage of relative abundance of halobiontic diatoms (tolerance or requirements for dissolved salts) was more than 26 percent lower in 2013 compared with 2004. These results are mixed but indicate slightly positive changes in the algal assemblage at this highly urban site.

Fewer invertebrate taxa and lower diversity detected in 2013 compared with previous sampling years were in contrast to the percentage of EPT taxa, which was 11 percent higher in 2013 than 2004 (table 5 and fig. 6A). However, some EPT taxa are known to be relatively tolerant (Barbour and others, 1999), including some mayfly (Baetis intercalaris) and caddisfly (Cheumatopsyche) taxa that dominated in 2013 at this site for orders Ephemeroptera and Trichoptera, respectively. The percentage of noninsects was greater than 20 percent in most sampling years except 2007, and the percentage was only slightly changed in 2013 compared with 2004. This likely contributed to "fairly poor" and "poor" ratings by the HBI-10 and 
mIBI, respectively, for invertebrate assemblages at this site in 2013. Overall, the invertebrate assemblage at this site has not yet shown the improvements hoped for after the 2002 restoration. The invertebrate assemblage in 1993 was rated "fair" based on HBI scores (Peters and others, 1998).

Changes in habitat as a result of the 2002 restoration were initially reflected in generally positive differences in the fish assemblage but sampling results for 2013 were not positive. Sampling at the site before the restoration detected six species of disturbance-tolerant fish (fathead minnow, green sunfish, Lepomis gibbosus [pumpkinseed], green sunfish $\times$ pumpkinseed hybrid, and Ameiurus melas [black bullhead]) in 1993 but only one to two species (fathead minnow and green sunfish) in 1994 and 1995 (Sullivan, 1997). Sample collection resulted in the collection of 8 species in 2004; 11 and 12 species in 2007 and 2010, respectively; and 7 species in 2013 (table 7). Fish abundances in USGS sample collections during the 1990s at this site were fewer than 50 individuals, and IBI scores rated "poor" in 1993-5 (Sullivan, 1997; Peters and others, 1998). In 2007, abundance peaked at 170 individuals and, in 2013, abundance was only 25 , too few to compute a standard IBI (value of 15). Of 25 individuals, 13 were green sunfish; therefore, the IBI was rated "very poor." Because of the low numbers of fish captured, invertebrates are probably a better indicator of the water quality here. Diversity was 12 percent lower in 2013 than in 2004 with values of 1.50 and 1.71, respectively.

Several environmental stressors are present at the Lincoln Creek site. In 2004, 2010, and 2013 (no data collected in 2007), maximum instantaneous discharge normalized by drainage area was high at Lincoln Creek relative to the other sampled sites, and this metric is an indicator of flood and scour effects on stream channels with higher values indicating greater effects (fig. 11L). Fecal coliform counts were many times higher than at less urban sites such as the Milwaukee River near Cedarburg; chronic human fecal contamination of Lincoln Creek from sanitary sewage sources has been a well-known issue (Sauer and others, 2011). Thomas and others (2007), who studied the same ecological monitoring sites, determined that fecal coliform counts increased with increasing total urban land. The Milwaukee River near Cedarburg site had the lowest fecal coliform counts and urban land percentage, followed by the Milwaukee River at Milwaukee site. Sites with the highest urban land percentages also had the highest fecal coliform counts: Lincoln Creek, Underwood Creek, Root River at Greenfield, and Kinnickinnic River. The highest mean total phosphorus of all sites was at Lincoln Creek in 2007 at $0.260 \mathrm{mg} / \mathrm{L}$, which is greater than the State of Wisconsin's criterion of $0.075 \mathrm{mg} / \mathrm{L}$, averaged May through October, to minimize nuisance algal/plant growth in wadable streams (Wisconsin Department of Natural Resources, 2019). Although most phosphorus in Milwaukee area watersheds is thought to come from urban and agricultural nonpoint sources, some municipal water supplies in Milwaukee began adding a soluble phosphate additive as an anticorrosive agent for copper and lead pipe abatement in the 1990s; through industrial and wastewater treatment sources, this can contribute additional phosphate to streams including Lincoln Creek (Wisconsin Department of Natural Resources, 2013; William Wawrzyn, Wisconsin Department of Natural Resources, written commun., December 5, 2014). Chloride concentrations at Lincoln Creek were high relative to other sites, and mean chloride concentrations in 2007 greatly exceeded the EPA chronic water-quality criterion of $230 \mathrm{mg} / \mathrm{L}$ and Wisconsin's chronic criterion of $395 \mathrm{mg} / \mathrm{L}$ (Wisconsin Department of Natural Resources, 2019), reflecting this site's highly urban setting and contributions from road salt runoff. PAH analyses of SPMD extracts in 2007 indicated estimated water concentrations of 130 nanograms per liter (ng/L) pyrene and $520-560 \mathrm{ng} / \mathrm{L}$ total PAHs, the highest concentrations among six sites sampled that year. Baldwin and others (2013) detected a variety of organic waste compounds at the Lincoln Creek site in 2006-9; in at least 80 percent of sediment samples, PAHs, antimicrobial disinfectants, and detergent metabolites were detected in moderately high concentrations $(>1,000$ micrograms per liter $[\mu \mathrm{g} / \mathrm{L}])$ and steroids were detected in high concentrations $(\geq 10,000 \mu \mathrm{g} / \mathrm{L})$. In the same study for a larger suite of organic waste compounds, detection frequencies in porewater samples were also 80 percent or greater. With regard to stream habitat, the channel stability at Lincoln Creek was the highest of any sampled streams. This finding reflected the construction design of having a low flow channel for fish passage within a much larger channel for passage of frequent flood flows. Regardless, higher values for channel stability across all sites and dates were significantly correlated with lower numbers of invertebrate EPT genera $(p<0.001)$. High stream discharges that carry urban runoff with sewage, nutrients, chloride, and organic waste compounds are important environmental stressors in this and many other small urban streams.

\section{Milwaukee River at Milwaukee}

Although the aggregate bioassessment ranking for this site in 2013 was in the top tier of sites in group 1, the actual value was worse than in 2004 (table 8). The mean bioassessment ranking for algae in 2013 fell to the bottom tier of sites in group 4, which was in contrast to relatively high rankings for invertebrates and fish and a high aggregate bioassessment ranking in 2013 and 2004. The algal assemblage at this site reflects the diverse and complex nature of a large river. The most algal taxa (70) collected from any site in 2004 were detected here (table 2), including three phyla (diatoms and green and blue-green algae) in 2004 and the addition of red algae in 2010 and 2013 (tables 2 and 3). Samples collected in 2013 had lower algal biovolume than in 2004. The relative abundance of diatoms was more than 20 percent lower in 2013 compared with 2004 and the relative abundance of blue-green algae was also more than 15 percent higher in 2013 compared with 2004. The abundance of pollution-tolerant diatoms in 2013 was about 10 percent higher compared with 2004, and this metric is one of the two metrics used in the aggregate bioassessment ranking. Diversity improved from high stress 
(diversity index <1.5) in 2004 to moderate stress in 2013. Overall, the algal assemblage remains diverse but the shift to more pollution-tolerant diatoms, including fewer diatoms overall and a greater abundance of blue-green algae, indicates a decline in water quality at this site from 2004 to 2013.

The numbers of invertebrate taxa (species and genera) collected were lower each year after 2004 (table 5), which also supports the water-quality assessment based on algal assemblages. The total number of invertebrate species and genera, and diversity, were more than 36 percent lower in 2013 compared with 2004. In 2013, the diversity of 1.94 was much lower than in all previous sampling years and was similar to Lincoln Creek. The invertebrate mIBI score rated "fair" in 2013, in contrast with "good" ratings in all previous sampling years and scored 15 percent lower than in 2004. In 2007, the percentage of noninsects was higher than in other sample years because of the presence of worms, oligochaetes, and flatworms. Increasing percentages of noninsects at this site, together with the decrease in total taxa, lower diversity, and mIBI ratings, all point toward declines in water quality and stream condition at this site, especially in comparison to upstream near Cedarburg. This pattern indicates that water-quality degradation is fairly localized, because the upstream Cedarburg site does not indicate a similar waterquality decline.

Similar to the upstream site near Cedarburg, the Milwaukee River at Milwaukee's fish assemblage benefits from its size and diversity of habitat but fish abundance has scored lower than Cedarburg with the exception of 2007 , when sampling at Cedarburg was limited to one upstream pass because of severe weather (table 7). The fish IBI was rated "good" in 2004-10 to "excellent" in 2013. Fish metrics for this site were similar across years except that no darter species were collected in 2013. Specifically, Percina caprodes (common logperch), which made up 17 percent of fish abundance in 2004, were less than 2 percent in 2007 and 0 in 2013. In 2010, the sample from this site included round gobies for the first time, and the 2013 survey detected abundant individuals of this invasive fish again at the site. The round goby was 16 percent of the overall fish abundance in 2010 and about 5.8 percent in 2013 .

With respect to potential environmental stressors at this Milwaukee River site, mean fecal coliform bacteria counts were much higher in 2010 and 2013 at 7,209 and 1,078 colony forming units per 100 milliliters (CFU/100 mL), respectively, when compared with $<700$ CFU/100 mL in 2004 and 2007. The mean E. coli bacteria counts for 2010 were more than twice that of other sampling years and may have been related in part to the historic flooding on July 22, 2010 (also high in 2010 at the Cedarburg site). These results indicate possible sanitary waste contamination at this site. Across all sites and years, increasing fecal coliform bacteria concentrations were significantly correlated to higher abundances of high total phosphorus-indicator diatoms (fig. 11I) and lower abundances of scraper invertebrates (fig. 12G). Results from SPMD tests indicated potential toxicity at this site in 2010 and 2013 from hydrophobic organic chemicals such as PCBs and (or) PAHs, and so on, although PCBs are more likely than PAHs, based on PAH screening that detected low pyrene concentrations in 2013 (table 9). PCB deposits less than 1 mile upstream from the Estabrook Park site represent the largest known deposit in the Milwaukee Estuary Area of Concern (Epping Overholt, 2014). Sediment remediation is in progress by the State and Federal government (Wisconsin Department of Natural Resources, 2016). Chloride concentrations that may be a problem in smaller streams are more diluted out. Embeddedness at the invertebrate microhabitat sites in 2013 was more than double that seen in 2004 ( 30 and 82, respectively) and this can adversely affect streambed-dwelling organisms, especially the freshwater mussel assemblage at this site. The percentage of urban land and percentage of impervious surface increased by about 1 percent from 2004 to 2013 (that is, between NLCD datasets for 2006 and 2011). The stressors listed above are commonly associated with urban runoff (Coles and others, 2012).

\section{Willow Creek}

The aggregate bioassessment ranking for Willow Creek in 2013 was at the low end of the group 2 tier of sites, yet the ranking still indicated fairly good water quality relative to other sampled sites (table 8). However, algae ranked much lower than invertebrates and fish in 2013. Three algal phyla (diatoms and green and blue-green algae) were collected in 2004, with the addition of red algae in 2007 (table 3). Lower algal biovolume was measured in 2013 than 2004 (table 2). The percentage of relative abundance of diatoms was more than 40 percent lower in 2013 compared with 2004, and the percentage of relative abundance of blue-green algae was more than 28 percent higher in 2013 compared with 2004. Pollution-sensitive diatoms were about 27 percent lower in 2013 compared with 2004, whereas the percentage of relative abundance of eutrophic diatoms was 20 percent higher in 2013 than 2004. The decrease in diatom abundance, especially pollution-sensitive diatoms, together with an increase in bluegreen algae and eutrophic diatoms indicate a more degraded algal assemblage in 2013.

Most metrics for the invertebrate assemblage in Willow Creek were more than 10 percent lower in 2013 than in 2004 (table 5). The mIBI and percentage of EPT taxa did not demonstrate much variation between sampling years. The largest negative difference in metric values was seen for diversity, and the percentage of noninsects more than tripled from 12.2 to 43.6 percent among years. Noninsect taxa, which are generally considered to be more tolerant of degraded environmental conditions (amphipods, isopods, and snails), were more common in 2013. Both differences in metric values indicate a more degraded invertebrate assemblage in 2013 than 2004.

The fish assemblages at this site are affected by its lowgradient and sand-bottomed habitat with cover provided by overhanging grasses in the lower part of the reach and relatively dense tree cover in the upper part of the reach. Most of 
the fish were collected in the lower part of the reach. In 2013, the fish assemblage was dominated by Etheostoma nigrum (johnny darter), followed by creek chub, Culaea inconstans (brook stickleback), and Umbra limi (central mudminnow). Although the number of fish collected was more than 51 percent lower in 2013 than 2004, the number of taxa (genera and species) was 17 percent higher in 2013 (table 7). Although the IBI score was more than 23 percent higher in 2013 than 2004, this still indicated a rating of "poor" for the fish assemblage in 2013 and 2004.

Environmental data for this site are incomplete because of missing data for flow and water chemistry, and it is therefore difficult to evaluate potential stressors on the biota. In 2013, the percentage of relative abundance of nitrogenautotrophic diatoms (indicating low organic nitrogen concentrations) was 19.5 percent and was higher than in other sampling years, especially 2004, and higher than for all other sites and dates. This finding indicates algal assemblages at Willow Creek may be nitrogen limited. Chlorophyll $a$ in benthic algal samples was an order of magnitude higher in 2013 (188 milligrams per square meter $\left[\mathrm{mg} / \mathrm{m}^{2}\right]$ ) compared with 2007 and $2010\left(20.8 \mathrm{mg} / \mathrm{m}^{2}\right.$ and $11.3 \mathrm{mg} / \mathrm{m}^{2}$, respectively); chlorophyll $a$ was not characterized in 2004. The percentage of urban area increased slightly (about 1 percent) from 2004 to 2013 to 25 percent and may have contributed additional urban runoff.

\section{Menomonee River at Menomonee Falls}

Aggregate bioassessment scores for algae, invertebrates, and fish at this site ranked the Menomonee River at Menomonee Falls second in group 1 for 2013, improving from fourth in 2004 and indicating better water quality than most other sites in the study (table 8). Four algal phyla (diatoms and green, blue-green, and red algae) were collected in 2013 and 2004 (table 3); however, the fewest algal taxa (37) from any site in 2013 were collected here when compared with all other sampled sites (table 2). The relative abundance of diatoms was more than 25 percent lower in 2013 compared with 2004; relative abundance of blue-green algae was more than 20 percent higher in 2013 compared with 2004 (table 3). Higher algal biovolume was collected in 2013 than 2004. These metric changes all indicate the algal assemblage was degraded in 2013 compared with 2004. However, the relative abundance of halobiontic diatoms was more than 10 percent lower in 2013 compared with 2004 despite a steady increase in waterborne chloride concentrations from 2004 to 2013; the mean chloride concentration in 2013 was less than the EPA chronic waterquality criterion of $230 \mathrm{mg} / \mathrm{L}$.

The total number of invertebrate taxa was more than 10 percent lower in 2013 compared with 2004 (table 5). Although the HBI was lower, resulting in a "good" rating in 2013, diversity and the mIBI were more than 10 percent lower in 2013 than in 2004, and the ratings for the mIBI were "fair" in both years. The percentage of EPT was similar between 2013 and 2004, as was the percentage of noninsects. The use of the HBI and EPT metrics in the bioassessment rankings gave a more positive ranking for the 2013 sample than was indicated by other invertebrate metrics. Dominant taxa were a tolerant mayfly, followed by a riffle beetle (Stenelmis), and several species of sensitive and tolerant caddisflies.

The fish IBI was higher in 2013, resulting in a "fair" rating despite a 60 percent lower total number of fish collected when compared with 2004 (table 7). Sampling crews did not indicate any major issues that would have caused such variability in the total number of fish collected. The number of species, IBI, and number of native species were all more than 10 percent higher in 2013, and the percentages of pollutiontolerant fish and forage fish tolerant to low DO decreased. These results indicate the fish assemblage, water quality, and stream condition remain relatively good overall.

Environmental stressors at this upstream Menomonee River site may be related to urban runoff that delivers nutrients, chloride, and other contaminants to the stream. In 2013, the maximum instantaneous discharge, normalized by drainage area, was about 50 percent of that recorded for 2004 (16.3 compared with 31.4) but, as with several other area streams in 2010, this metric was high compared with other sample years. Historical water-quality data for this site from the MMSD indicated that this site met water-quality criteria for total phosphorus and fecal coliform less than 50 percent of the time (Milwaukee Metropolitan Sewerage District, 2004). Mean concentrations for total phosphorus in all sampling years ranged from 0.066 to $0.090 \mathrm{mg} / \mathrm{L}$, greater than the State of Wisconsin's criterion of $0.075 \mathrm{mg} / \mathrm{L}$, averaged May through October, to minimize nuisance algal/plant growth in wadable streams (Robertson and others, 2006; Wisconsin Department of Natural Resources, 2019). Occasional excess nutrients from phosphorus and fecal contamination from runoff and wastewater contamination could be contributing to the declines in the algal assemblage, marked by fewer diatoms and more blue-green algae, which would have cascading effects on the invertebrate assemblage. Mean specific conductance has gradually increased since 2004 and was slightly higher in 2013 compared with 2004 (984 and $903 \mu \mathrm{S} / \mathrm{cm}$ at $25^{\circ} \mathrm{C}$, respectively), indicating an increase of dissolved solids such as chloride in runoff. Similarly, mean chloride concentrations steadily increased from 92 to $142 \mathrm{mg} / \mathrm{L}$ in 2004 to 2013 but were still less than the EPA water-quality criterion of $230 \mathrm{mg} / \mathrm{L}$ chloride. Although SPMDs were not deployed at this site in later years, fluorescence screening of SPMD extracts deployed in 2004 demonstrated high concentrations of PAHs.

\section{Little Menomonee River}

In 2013, the mean bioassessment rankings for this site were variable across all three groups of biota, and the aggregate bioassessment ranking was similar to 2004 (table 8). Three algal phyla (diatoms and blue-green and red algae) were detected in 2004; however, only diatoms and blue-green algae were detected in 2013 (table 3). Change in the relative abundance of any of the algal groups was less than 10 percent 
between 2013 and 2004, and red algal abundance was only 7.6 percent in 2004. Algal biovolume was more than two times higher in 2013 than 2004 (table 2). Pollution-sensitive diatoms were 25 percent higher in 2013 than 2004, and this metric is one of two metrics used in the aggregate bioassessment ranking. The relative abundance of halobiontic diatoms was 29 percent lower in 2013 than 2004. Overall, these metric results indicate less degraded algal assemblages at this site in 2013 than 2004.

The invertebrate assemblage at this site demonstrated mixed results for metrics. The number of species was 22 percent higher in 2013 than 2004, and the mIBI scored about 30 percent higher in 2013, resulting in a "fair" rating compared with a "poor" rating in 2004 (table 5). These metric outcomes were in contrast, however, with a diversity value that was more than 13 percent lower in 2013. The percentage of noninsects increased by more than 17 percent in 2013, and this may be the reason behind the increase in species number. The assemblage in 2013 was dominated by isopods, followed by midges. The HBI-10 score was about 12 percent higher in 2013 and, although the rating was worse than the "good" rating for this site in 2004, it corresponded to the same rating of "fair" as the mIBI in 2013.

In general, fish abundance at this site is low (less than 50), yet abundance was 86 percent higher in 2013 than in 2004 with 26 fish captured compared with 14 in 2004 (table 7). A 55 -percent decrease in the percentage of pollution-tolerant fish was seen in 2013 and the fish IBI score was 36 percent higher in 2013; however, because fewer than 50 fish were captured in any sampling event, the IBI was still rated "very poor" in 2013 as it was in 2004. The IBI values for this site should be taken with caution because fewer than 50 fish were captured in any year and, therefore, invertebrates provide a more accurate assessment than fish for this site.

The Little Menomonee River seems to have several stressors based on anomalous values for this site in significant correlations to the biota. This site was an anomaly for high ammonia nitrogen compared with all other sites, with mean concentrations greater than $0.17 \mathrm{mg} / \mathrm{L}$ in 2007,2010 , and 2013. Water-quality data were not collected by the MMSD at this site in 2004. The highest mean ammonia concentration among all sites was here in 2013 at $0.24 \mathrm{mg} / \mathrm{L}$, but this value is less than the EPA chronic water-quality criterion. Higher nitrogen ammonia concentrations were significantly correlated to higher relative abundances of diatoms with fairly high oxygen tolerance (more than 75-percent saturation) and sestonic algae. The highest average nitrite concentration among sites was at the Little Menomonee River in 2007 and, as noted earlier, nitrite is toxic and higher nitrite was significantly related to lower total fish species. Mean soluble phosphorus was more than twice as high in 2013 when compared with 2007 and 2010 at this site, and this higher amount of nutrients was reflected in algal biomass in 2013, when the chlorophyll $a$ concentration in benthic algal samples was $232 \mathrm{mg} / \mathrm{L}$, more than five times higher than in 2004. Mean calcium, magnesium, nickel, and zinc concentrations, and hardness and fecal counts, were successively lower each year from 2007 to 2013 and may indicate improvements in other aspects of water quality that could help explain the higher aggregate bioassessment ranking in 2013 compared with 2004. Although fluorescence screening from SPMDs in 2013 indicated relatively low pyrene concentrations, Microtox and P450RGS tests indicated moderate acute toxicity from synthetic organic chemicals, indicating that chemicals other than PAHs are causing toxicity at this site.

\section{Underwood Creek}

Mean bioassessment rankings in 2013 differed greatly among biota, and the highest ranking was for fish, followed by algae and then invertebrates (table 8 ). The aggregate bioassessment ranking for 2013 was at the bottom of the group 3 sites and similar to 2004. Three algal phyla (diatoms and green and blue-green algae) were collected at this site in 2004 and 2013 (table 3). The relative abundances of blue-green algae were more than 13 percent lower in 2013 compared with 2004, and the relative abundance of green algae was about 10 percent higher in 2013. About 99.8 percent of all algal biovolume was green algae. Pollution-sensitive diatoms were 21 percent lower in 2013 compared with 2004, and the algal assemblage was less than 30-percent pollution-sensitive diatoms in 2013 (table 2). Diversity improved from high stress (diversity index $<1.5$ ) in 2004 to moderate stress in 2013; however, algal biovolume in 2013 was more than an order of magnitude higher than in 2004, and the percentage of relative abundance of halobiontic diatoms was about 28 percent higher in 2013 compared with 2004. Overall, these results are mixed for the algal assemblage but indicate that runoff may be contributing excess nutrients and salt to this reach, which in turn, were related to a nearly complete dominance in biomass by green algae.

The invertebrate assemblage was more degraded in 2013 compared with 2004, as evidenced by more than 40 -percent decreases in the number of taxa (species and genera) and also diversity (table 5). The HBI-10 rating was "fairly poor" in 2013 compared with "fair" in 2004 because of an about 20 -percent change in the HBI-10 value. Although the mIBI value was 22 percent higher in 2013 compared with 2004, the mIBI rating was "poor" in all years. The lower diversity and HBI-10 metrics resulted in the low average bioassessment for the invertebrate sample from this site in 2013, second only to the Kinnickinnic River sample.

Most fish in this reach of Underwood Creek were captured in the downstream end below the concrete. The large scour pool at the bottom of the reach was not wadable for electrofishing except in 2007. Fish abundance was several times higher in 2007 when lower depths permitted seining in the lower part of the reach and electrofishing seemed ineffective, perhaps because of high conductance $(1,490 \mu \mathrm{S} / \mathrm{cm}$ at $25^{\circ} \mathrm{C}$ ). Two salmon were seen in the pool in 2004 but not captured and likely came upstream from the nearby Menomonee River. The number of fish captured in 2013 was about half the number captured in 2004; however, the numbers of total 
species and native species were more than 37 percent higher in 2013 compared with 2004 (table 7). Also, the percentage of pollution-tolerant fish was 79 percent lower in 2013 compared with 2004. The higher number of total and native species and lower abundance of pollution-tolerant fish together indicate the fish assemblage was less degraded in 2013 than 2004 and was reflected in an IBI rating of "fair" in 2013, compared with "very poor" in 2004.

The environmental stressors at this Underwood Creek site are related to urban runoff from frequent high storm flows, as evidenced by ongoing efforts by MMSD in the past decade to mitigate these effects. The most egregious effects of runoff are the mean chloride concentrations that were greater than $267 \mathrm{mg} / \mathrm{L}$ and greater than the EPA chronic water-quality criterion in all sampling years. Similarly, mean specific conductance values at this site in 2007 and 2013 were among the highest across all sampled sites. This site was also an anomaly for high total solids in 2013, and higher total solids concentrations were significantly related to higher mean nutrient tolerance values of invertebrate taxa $(p<0.001$; fig. 12F). The mean total nonpurgeable dissolved organic carbon was the highest across all sites in 2013 (fig. 13). High mean fecal coliform counts $(2,500-8,500 \mathrm{CFU} / 100 \mathrm{~mL})$ during all sampling years indicate chronic problems with untreated sewage at this site (Sauer and others, 2011). These water-quality metrics underscore multiple stressors at this site that are related to urban runoff.

\section{Honey Creek}

In 2013, the mean bioassessment rankings for Honey Creek were relatively consistent among algae, invertebrates, and fish, and this resulted in an aggregate bioassessment placing the site in group 3 (table 8 ). This was higher than the group 4 ranking computed for 2004 . The relative proportions of algal groups were similar among 2007, 2010, and 2013. Four algal phyla (diatoms and green, blue-green, and red algae) were collected in 2004 but only three were detected in 2013; red algae were absent in 2013 (table 3). The relative abundances of green and blue-green algae were more than 17 and 33 percent higher, respectively, in 2013 compared with 2004. Green algae dominated in all years, making up 98-100 percent of the algal biovolume. In addition, higher algal biovolume was collected in 2013 than 2004 (table 2). The algal assemblage was made up of less than 30 -percent pollution-sensitive diatoms in 2013. The percentage of relative abundance of nuisance algae was more than 12 percent higher in 2013 compared with 2004 (0). The percentage of relative abundance of halobiontic diatoms was more than 10 percent higher in 2013 compared with 2004.

Although similar differences were seen for the invertebrate assemblage as for the algal assemblage in a comparison between 2013 and 2004, diversity between 2013 and 2007 decreased by 47 percent (table 5). Although the HBI-10 scores rated "good" in 2013, "fair" in 2007, and "good" in 2004, the invertebrate mIBI rating was "poor" in 2013, lower than the "fair" rating in 2007. These two metrics are apparently reflecting different aspects of the invertebrate assemblage. The numbers of invertebrate taxa, percentages of noninsects, and percentages of EPT taxa were similar between 2013 and 2007. Overall, the mixed results for the metrics do not indicate improvements in the invertebrate assemblage over time.

In 2013, a total of 559 fish as 11 species were collected at Honey Creek; dominant taxa (more than 78 percent) were Rhinichthys atratulus (blacknose dace), followed by white sucker and creek chub (table 7). Although richness and number of native fish species in 2013 were greater than upstream in 2004, the values for these metrics were similar for 2013 and 2007 at the downstream site. The percentages of omnivorous fish and forage fish tolerant to low dissolved oxygen were more than 10 percent lower in 2013 when compared with 2004 , indicating a less degraded assemblage. The IBI score in 2013 was similar to 2007, which corresponded to "poor" ratings compared with a "very poor" rating in 2004. These metric values indicate the fish assemblage at the current site was less degraded in 2013 compared with 2007 but still poor (fig. 4).

Multiple environmental stressors may be having adverse effects on the aquatic community at this highly urbanized Honey Creek site. Although the mean chloride concentration in 2007 was just less than the EPA chronic water-quality criterion at $229 \mathrm{mg} / \mathrm{L}$ (fig. 12), values in all other ecological sampling years exceeded the EPA chronic water-quality criterion of $230 \mathrm{mg} / \mathrm{L}$. Although the HBI-10 value in 2013 was higher than predicted, the mIBI scores rated "poor" when the highest mean chloride concentration for this site was recorded at $403 \mathrm{mg} / \mathrm{L}$. The high chloride value in 2013 was reflected in the second highest chloride concentrations among all sites and dates (fig. 13C). Although the mean ammonia nitrogen concentration in 2007 , at $0.15 \mathrm{mg} / \mathrm{L}$, was among the four highest values for all sites and years (fig. 11A-B), concentrations in other sample years were relatively low (from the minimum reporting limit as nitrogen of $0.01 \mathrm{mg} / \mathrm{L}$ to $0.05 \mathrm{mg} / \mathrm{L}$ ). However, the mean nitrite concentration in 2013 was the second highest value among all sites and years. The BOD5 values at the upstream site in 2004, 2007, and 2013 were among the top five highest values among all sites and were more than $3.0 \mathrm{mg} / \mathrm{L}$; fecal coliform bacteria counts in 2007 and 2013 were the highest values among all sites at 22,269 and $28,780 \mathrm{CFU} / 100 \mathrm{~mL}$, respectively (figs. 11 and 12). The mean zinc concentration of $94 \mu \mathrm{g} / \mathrm{L}$ in 2013 was the highest value across all sites and years, and the concentration of $46 \mu \mathrm{g} / \mathrm{L}$ in 2004 was the second highest. The highest mean concentrations of copper and total solids in 2013 were the highest across all sites and years at 24.5 and $1,149 \mathrm{mg} / \mathrm{L}$, respectively. In 2013, the mean chromium concentration was $16.5 \mu \mathrm{g} / \mathrm{L}$, which was greater than mean values in other years and other sampled sites. These results indicate that urban runoff containing high chloride, fecal contamination, and other urban-associated chemicals are primary stressors at this site. This finding is supported by comparisons with other sites and relations of these stressors to biological metrics. In 2013, the second highest potential toxicity for P450RGS tests of SPMDs was measured 
at this site relative to other sampled sites, including a value higher than in 2007 and nearly three times higher than was measured at the Milwaukee River near Cedarburg (table 9). This finding indicates that the potential toxicity at this site was from synthetic organic compounds other than pyrene, which was relatively low in spite of findings for 2004 that PAH concentrations were high relative to other sampled sites (Thomas and others, 2007). With nearly 100-percent urban land in the watershed and more than 72-percent urban land in the stream buffer, there is little vegetation to slow or absorb runoff from a mean of 47-percent impervious surface in the watershed. This stream has relatively high runoff from storms. In 2010 and 2013, values for maximum instantaneous discharge per drainage area were high compared with most other sites, especially those with less urban land in the stream buffer, and values were similar to the Kinnickinnic River site with its concretelined streambed. High flows and scour are evident in many areas of severely eroded streambanks and loss of large canopy trees into the stream channel.

\section{Menomonee River at Wauwatosa}

Mean bioassessment rankings for the Menomonee River at Wauwatosa site in 2013 were similar between algae and invertebrates (table 8). In contrast, the ranking for fish in 2013 was much worse and the resulting aggregate bioassessment ranking placed the site into group 4, the lowest group with regard to water quality. Mean bioassessment rankings for fish assemblages in 2004 also ranked poorly but the aggregate ranking for the site was in group 3. The algal assemblage at this site included four phyla (diatoms and green, blue-green, and red algae) in 2004 but only three phyla in 2013 with the loss of red algae (table 3 ). The change in the percentage of relative abundance of any of the algal groups was less than 10 percent between 2004 and 2013. Higher algal biovolume was measured in 2013 than 2004 (table 2). The percentage of relative abundance of pollution-sensitive diatoms was more than 20 percent lower in 2013 compared with 2004, and the assemblage had only 7.5-percent pollution-sensitive diatoms in 2013. The percentage of relative abundance of halobiontic diatoms was more than 18 percent higher in 2013 compared with 2004, indicating higher salt concentrations in this stream.

The numbers of invertebrate taxa (species and genera) were more than 18 percent higher in 2013 compared with 2004 when the downstream reach was sampled and were also higher when compared with 2007 (table 5); however, diversity was 1.98 in 2013, more than 26 percent lower than in 2004. The percentage of EPT taxa in 2013 was 10 percent lower than in 2004 and steadily decreased from 2004 to 2013 . HBI-10 scores rated "fair" and remained unchanged from 2004 to 2013, as did the "poor" mIBI rating, but mIBI scores were about 22 percent lower than in 2004 and more than 40 percent lower than in 2007. These latter metric results indicate that the invertebrate assemblage at this site has degraded since 2004 and 2007.
Similar numbers of fish taxa were measured in 2013 compared with 2004, including six in 2013 and seven in 2004. The sampling reach in 2004 had a nonwadable pool at the apex of the only bend; a few fish may have retreated into this deep and clear pool during electrofishing and a large trout or salmon was observed to escape seine sampling. The early 2006 restoration of the reach around 68th Street and 70th Street made a larger area of the bend area nonwadable and necessitated moving the sample reach upstream to just above 70th Street. There were no barriers to fish movement between the 2004 reach and the new adjacent reach that was sampled in 2007-13. The restoration removed all trees on the left bank from downstream from 68th Street through most of the current reach. The fish IBI rated "very poor" in 2004 and 2013. In 2016, the last of all fish barriers were removed downstream from the sample site, and if migration for most fish species is unimpeded from Lake Michigan to Menomonee Falls, this could result in positive changes to the fish assemblage.

A comparison between this site and the upstream site at Menomonee Falls is useful in evaluating important environmental stressors at the Wauwatosa site. For example, the maximum instantaneous discharge, normalized by drainage area, was higher in each ecological sampling year at the downstream Wauwatosa site and more than double in 2010 (42 and 87 cubic feet per second per square mile at Menomonee Falls and Wauwatosa, respectively). The mean DO concentration in ecological sampling years was between 7 and $9 \mathrm{mg} / \mathrm{L}$ at Menomonee Falls but $11 \mathrm{mg} / \mathrm{L}$ in all years at Wauwatosa. Perhaps most importantly, the mean chloride concentrations in 2007-13 at Wauwatosa were greater than the EPA chronic water-quality criterion of $230 \mathrm{mg} / \mathrm{L}$. Mean chloride concentrations at Menomonee Falls, although steadily increasing from 2004 to 2013, were lower than the mean value for Wauwatosa in all years including 2004. Higher specific conductance values at Wauwatosa reflected this difference in chloride. Fecal coliform concentrations were an order of magnitude higher at Wauwatosa in all years compared with concentrations at Menomonee Falls. At Wauwatosa, Baldwin and others (2013) detected a large suite of organic waste compounds in more than 80 percent of stormwater samples, including antioxidants, dyes/pigments, fire retardants, PAHs, plasticizers, solvents, herbicides, insecticides, detergent metabolites, flavors and fragrances, human drugs (nonprescription), and steroids. Many of these same compounds were detected in sediment, especially PAHs at $\geq 10,000 \mu \mathrm{g} / \mathrm{L}$. For one PAH compound, they also measured the highest fluoranthene concentration (14,900 micrograms per kilogram) among all sites in a sediment sample collected from the Wauwatosa site during 2006-9. Similar to its tributary, Honey Creek, these results indicate that urban runoff containing high chloride, fecal contamination, and other urban-associated chemicals are all important stressors at the Menomonee River at Wauwatosa. 


\section{Kinnickinnic River}

The concrete-lined channel of the Kinnickinnic River site was the lowest ranked of the group 4 sites in aggregate bioassessment rankings for 2013 and 2004, with consistently low mean bioassessment rankings for algae, invertebrates, and fish (table 8). The algal assemblage at this site included three phyla (diatoms and green and blue-green algae) in 2004 and 2013 (table 3). The change in the percentage of relative abundance of any of the algal groups was less than 10 percent. Higher algal biovolume was collected in 2013 than 2004 (table 2). The percentage of pollution-tolerant diatoms dropped from about 28 percent in 2004 to 17 percent in 2013. Diversity was rated as high stress (diversity index $<1.5$ ) in 2004 and moderate stress in 2013. The percentage of relative abundance of eutrophic diatoms was more than 14 percent higher in 2013 compared with 2004. The percentage of relative abundance of halobiontic diatoms was more than 20 percent higher in 2013 compared with 2004 . The algal assemblage at this site had less than 30-percent pollution-sensitive diatoms in all years except 2007. Although diversity was higher in 2013 than 2004, the higher percentages of eutrophic and halobiontic diatoms and lower percentage of pollution-sensitive diatoms in 2013 indicate that the assemblage is more degraded than in 2004.

The number of invertebrate species and genera was at least 47 percent lower in 2013 than 2004 and, as a result, diversity was about 65 percent lower in 2013 than 2004 (table 5). Good indicators were that the percentage of noninsects was more than 21 percent lower and the percentage of EPT taxa was 11 percent higher in 2013. The site rated "fairly poor" by the HBI-10 in 2013 and 2004 but it rated "very poor" by the $\mathrm{mIBI}$ in 2013 compared with "poor" in 2004; the mIBI score was 50 percent lower in 2013. These mostly adverse results indicate that the already poor invertebrate assemblage has further degraded since 2004.

Most fish collected during sampling were fathead minnows, a species that is tolerant of poor water quality. Only one common shiner and one fathead minnow were collected in 2007, and no fish were seen or captured in 2013. As such, there were too few fish captured during all years at this site to confidently calculate an IBI, resulting in a "very poor" IBI rating (table 7). With the highly urban setting (99-percent urban land), shallow water with meager habitat, and little or no refuge from effects of high storm flows, "very poor" ratings for fish were not unexpected in this reach of the Kinnickinnic River.

Several environmental stressors at the Kinnickinnic River site were significantly correlated to poor rankings of the aquatic community. During ecological sampling years, mean values for maximum instantaneous discharge, normalized by drainage area, were high relative to most other sites and emphasize the high storm flows that are commonly recorded at this site. Four of the five highest mean DO concentrations (greater than $14 \mathrm{mg} / \mathrm{L}$ ) across all sites and years were at this site (fig. 11E). Such high mean DO concentrations often result from excessive nutrients and algae that can cause contrasting low mean DO concentrations at other times of the day when algal respiration dominates. All fish captured in 2004 and 2010 (fathead minnow, common shiner) are forage fish known to be tolerant to low DO concentrations. In 2007, the mean BOD5 value of $4.9 \mathrm{mg} / \mathrm{L}$ was one of the four highest values across all sites and dates, and higher BOD5 was correlated to fewer scraper invertebrates (fig. 12H). Concentrations of fecal coliform bacteria at the Kinnickinnic River site were many times higher than at sample sites in less urbanized areas (fig. 12G) and likely contributed to high BOD5 values. This agrees with findings by Templar and others (2016) that indicated chronic human fecal contamination in the Kinnickinnic River. Related to nutrients and algae, high total phosphorusindicator diatoms (optima greater than or equal to $0.10 \mathrm{mg} / \mathrm{L}$ total phosphorus) were abundant at more than 73 percent of the algal cells in all years (fig. $11 N$ ); mean total phosphorus concentrations were 0.11 or higher in all ecological sampling years and greater than the State of Wisconsin's criterion of $0.075 \mathrm{mg} / \mathrm{L}$, averaged May through October, to minimize nuisance algal/plant growth in wadable streams (Wisconsin Department of Natural Resources, 2019). The high total phosphorus concentrations correlated to the higher percentage of total phosphorus-indicator diatoms and likely had indirect effects on the invertebrates and fish in this urban stream. Mean chloride concentrations were already high at $220 \mathrm{mg} / \mathrm{L}$ in 2004 but were greater than the EPA chronic water-quality criterion of $230 \mathrm{mg} / \mathrm{L}$ for all recent years, including $302 \mathrm{mg} / \mathrm{L}$ in 2013 . Mean chloride concentrations this high were correlated with invertebrate HBI-10 and mIBI values, and fish IBI values that indicated more degraded assemblages (fig. 12A-C, fig. 13A). Baldwin and others (2013), in a study in 2006-9 at many of the same sites as the current study, determined some of the highest detection frequencies and concentrations of organic waste compounds were from the Kinnickinnic River site. They also determined that the highest stormflow concentrations of three PAHs (fluoranthene, phenanthrene, and pyrene) were in one sample from this highly urban site. In the current study, moderately high PAHs compared with the Milwaukee River near Cedarburg site were detected in SPMDs deployed at the Kinnickinnic River site in 2007 during base flow (table 9). In summary, high storm flows, DO, BOD5, fecal coliform, total phosphorus, chloride, and PAHs are important stressors on aquatic communities at the Kinnickinnic River site.

\section{Oak Creek}

The aggregate bioassessment ranking for Oak Creek was better in 2013 than in 2004, placing the site in group 3 (table 8); however, the 2013 mean bioassessment rankings differed greatly among algae, invertebrates, and fish and this underscores the importance of assessment with multiple groups of aquatic organisms. Algal assemblages at this site were made up of three phyla (diatoms and blue-green and red algae) in 2004 and four phyla in 2013 with the addition of green algae (table 3 ). The percentage of relative abundance of blue-green algae was more than 23 percent lower in 2013 
compared with 2004; the percentage of relative abundance of red algae was more than 22 percent higher in 2013 compared with 2004. Higher algal biovolume was collected in 2013 than 2004 (table 2). The percentage of relative abundance of halobiontic diatoms was more than 26 percent lower in 2013 compared with 2004, an indicator of improved water quality. Another indicator is that pollution-sensitive diatom abundance increased by more than 14 percent from 2004 to 2013, which partly accounts for the higher ranking in mean bioassessment for algae for this site in 2013.

Invertebrate metrics indicated more degraded water quality at Oak Creek compared with algal metrics, with more than 39 percent fewer species and genera in 2013 compared with 2004 (table 5). As a result, diversity at this site was about 48 percent lower in 2013. The 14 percent higher value for the percentage of EPT taxa was apparently due to the loss of several midge taxa and riffle beetles, such that the remaining caddisfly taxa contributed more to the total invertebrate abundance and a higher percentage of EPT taxa. There was no difference in the HBI-10 or invertebrate mIBI when compared with 2004, indicated by ratings of "fair" or "poor" for the HBI-10 and mIBI, respectively; however, differences in the other metrics between 2004 and 2013 seem to indicate degradation of the invertebrate assemblage.

A total of 78 fish were collected at this site in 2013, compared with 218 in 2004, and several fish metrics indicated degradation in the 2013 assemblage when compared with 2004 (table 7). The total number of species was 14 percent lower, and the number of native species was 29 percent lower than in 2004. In addition, there were 33 percent more forage fish tolerant to low DO. Green sunfish and white suckers made up 81 percent of the fish individuals in 2013; green sunfish especially are known to be tolerant of environmental extremes including low DO. The creek chub, a species that is tolerant to short-term low DO, made up more than half the individuals in 2004 but declined in abundance with each passing year and made up only 7.7 percent of fish in 2013. Based on the fish IBI, the assemblage was rated as "very poor" in each sampling year, including a score of 7 in 2013 compared with a score of 5 in 2004. The IBI was the only fish metric used in the aggregate bioassessment.

The environmental stressors on the aquatic community at the Oak Creek site include chemicals from runoff and extreme high flows from impervious surfaces. Mean chloride concentrations were at and greater than the EPA chronic water-quality criterion of $230 \mathrm{mg} / \mathrm{L}$ in 2004 and 2013, respectively. Higher chloride was correlated with worse rankings for the invertebrate HBI-10 and mIBI and the fish IBI (fig. 12A, B; fig. 13A). The maximum instantaneous discharge, normalized by drainage area, was higher overall than at other less urban sites and was 34 percent higher in 2013 compared with 2004, indicating more high flows from storms that scour the streambed and can damage or kill aquatic organisms. This indication of increased urban runoff was in addition to more than 80 percent higher fecal concentrations in water in 2013 compared with 2004, an indication of higher wastewater input as well. Synthetic organic chemicals, likely from runoff, are also a concern at this site as evidenced by TEQs from P450RGS toxicity tests that were more than three times as high in 2013 than in 2007 (table 9).

\section{Root River at Greenfield}

The aggregate bioassessment ranking for Root River at Greenfield placed it with the lowest water-quality sites, placing it in group 4 in 2013 compared with group 3 in 2004, indicating a lower rank compared with the other sampled sites (table 8). This low ranking in 2013 was because of low mean rankings for invertebrates and fish, in spite of a higher mean ranking for algae. The mean bioassessment ranking for algae in 2004 was also a higher ranking than for invertebrates or fish (Scudder Eikenberry and others, 2010); however, this difference for algae alone from 2004 to 2013 indicates more degraded algal assemblages in 2013. Algal assemblages at the Root River at Greenfield site were quite different between 2013 and 2004 (table 3). This site had the fewest (28) algal taxa of all sites in 2004 but the most (70) taxa of all sites in 2013 (table 2). Three phyla (diatoms and blue-green and red algae) were collected in 2004, and five phyla (diatoms; green, blue-green, and red algae; and euglenoids) were collected in 2013. Lower algal biovolume was collected in 2013 than 2004. Although the percentage of biovolume of diatoms was about 14 percent higher, the percentages of biovolume of green and blue-green algae were about 18 and 11 percent higher, respectively, in 2013 compared with 2004. The percentage of biovolume of red algae was only 46 percent in 2013 compared with about 89 percent in 2004. Diversity for algae improved from high stress (diversity index $<1.5$ ) in 2004 to moderate stress in 2013, but the higher biovolume of green and blue-green algae in 2013 and lower mean bioassessment ranking for algae in 2013 indicate that the algal assemblage is more degraded than in 2004.

Invertebrate assemblages were more degraded in 2013 at this site as evidenced by a "fairly poor" HBI-10 rating, compared with a "fair" rating in 2004 (table 5). Also, the number of genera was 27 percent lower even though there was no difference in the overall number of species. This decrease in genera was reflected in the diversity, which was about 34 percent lower in 2013 than in 2004. The invertebrate mIBI rating was "poor" in all sampling years. The dominant taxon in 2013 was an isopod (Caecidotea intermedia, 53 percent) that is known to be a relatively pollution-tolerant noninsect (Barbour and others, 1999), followed by two pollution-tolerant taxa, a caddisfly (H. betteni, 8.2 percent) and a black fly (Simulium vittatum group, 6.0 percent).

Although 179 fish were collected from this site in 2004, only 11 fish were collected at this site in 2013, a decrease of 94 percent (table 7). Seining was not possible at this site in 2013 because of abundant woody debris, but it is doubtful that this was the reason for the substantially lower abundance. From field notes, rain the night before and morning of sampling in 2013 resulted in runoff and turbid water that 
probably contributed to sampling inefficiency by the fish crew. The total of 11 fish captured was too few to have confidence in the 2013 IBI score of 2 ("very poor"); however, the Wisconsin Department of Natural Resources also sampled the Root River at Greenfield site in 2013 and computed an IBI score of 10, again "very poor" (Craig Helker, Wisconsin Department of Natural Resources, oral commun., January 16, 2015).

The Root River at Greenfield has multiple environmental stressors including nutrients, such as high mean ammonia nitrogen and total nonpurgeable inorganic carbon, indicated by the anomalous values for these constituents (figs. $11 A$ and $D$ ). The lowest values for mean DO among all sites in all ecological sampling years occurred at this site (fig. $11 F$ ) and low DO is a known problem for the Root River because of low water levels (Milwaukee Metropolitan Sewerage District, 2005). Fecal coliform and BOD5 were at least two times higher than downstream at the Root River near Franklin site in all sampling years. The mean chloride concentration was greater than the EPA chronic water-quality criterion of $230 \mathrm{mg} / \mathrm{L}$ in each sampling year, and this was also reflected in high mean specific conductance. Specific conductance at the time of ecological sampling in 2007 was the highest among all sites. Zinc, as an indicator of urban runoff at this site, was again much higher than at the Root River near Franklin site. Maximum instantaneous discharge, as normalized by drainage area, was high relative to several other sites including downstream at the Root River near Franklin except in 2010, indicating that scour from high discharge affects habitat at this site.

\section{Root River near Franklin}

Mean bioassessment rankings in 2013 for the Root River near Franklin site differed among algae, invertebrates, and fish; the lowest ranking was for fish, followed by invertebrates and then algae (table 8). The mean of these rankings placed the site in group 2 for the aggregate bioassessment ranking and within the same group and with the same ranking as 2004 . The algal assemblage at this site included three phyla (diatoms and blue-green and red algae) in 2004 and five phyla (diatoms; green, blue-green, and red algae; and euglenoids) in 2013 (table 3). The percentage of relative abundance of blue-green algae was more than 26 percent higher in 2013 compared with 2004, whereas the percentage of relative abundance of red algae was more than 36 percent lower in 2013 compared with 2004. Higher algal biovolume was collected in 2013 than 2004, and green algal biovolume dominated in 2013 at about 68 percent (tables 2 and 3). Diversity improved from high stress (diversity index $<1.5$ ) in 2004 to moderate stress in 2013. The percentages of pollution-tolerant diatoms and pollution-sensitive diatoms were lower in 2013, and the percentage of pollution-moderate diatoms was higher. The higher abundance of blue-green and green algae in 2013 than 2004, together with the presence of euglenoids, indicate poorer water quality. In summary, the 2013 results for algal assemblages were mixed.
The number of invertebrate genera was 16 percent higher in 2013 than 2004; however, diversity decreased by about 18 percent (table 5 ). The lower diversity in 2013 is probably because of a change in dominance of taxa (evenness), which is a component of diversity in addition to taxa richness. Several midge taxa were present in much higher abundance in 2013 than 2004. Even though there was no change in the invertebrate mIBI, which rated "fair" from 2004 and 2013, the mIBI rated "poor" in 2007 and 2010. Plentiful live native freshwater mussels were observed at this site in 2004, though none were collected in the invertebrate sample. The 2013 sample contained one Potamilus alatus (pink heelsplitter mussel); however, our methods are not designed to quantify mussel populations because of their highly patchy nature of their distribution in streams.

Similar to the decrease seen upstream in the Root River at Greenfield, total abundance of fish in the river near Franklin was about 83 percent lower in 2013 compared with 2004 (table 7). In 2013, only 31 fish were captured, too few to have high confidence in the computed IBI (17 or "very poor") and this rating was lower than the "poor" IBI rating in 2004. Seining was not possible at this site in 2013 because of abundant woody debris that snagged the net. In addition, recent rains had caused runoff and high turbidity that may have decreased sampling efficiency. Richness has remained relatively low at this site throughout the sampling years and was 25 percent lower in 2013 compared with 2004. Dominant fish in 2013 were tolerant taxa: green sunfish (35 percent) and creek chub (29 percent). Although white suckers made up nearly one-third of all fish in 2004, no suckers were detected in 2007 and their abundance was low in subsequent years.

Environmental stressors at the Root River near Franklin site were fewer than upstream at the Root River at Greenfield site after traveling miles through less developed land. Values for maximum instantaneous discharge as normalized by drainage area were 40 percent higher in 2013 than 2004 and indicate higher flood effects and scour, yet mean zinc concentrations were nearly one-third lower in 2013 than 2004 and higher concentrations of zinc are generally considered to be indicators of urban runoff as mentioned earlier. Mean chloride concentration was also 40 percent higher in 2013 at $204 \mathrm{mg} / \mathrm{L}$ but still less than the EPA chronic water-quality criterion. Means for total and dissolved solids in water were 10-12 percent higher in 2013 than 2004. Fortunately, mean fecal coliform counts in 2013 were an order of magnitude lower than in 2004 and were lower in 2010 also. Mean silt depth for the reach was three times higher in 2013 than 2004, at 2.9 and 0.75 , respectively. These increases could have adverse effects on the freshwater mussel populations at this site and may be related to increased construction in the watershed as agricultural land is transformed into urban land. 


\section{Jewel Creek}

This small stream ranked in group 1 for 2013 and 2004, with relatively similar mean bioassessment rankings among invertebrates and fish for 2013. The algal assemblage at Jewel Creek included three phyla (diatoms and blue-green and red algae) in 2004 and five phyla (diatoms; green, blue-green, and red algae; and euglenoids) in 2013 (table 3). The percentages of relative abundance of diatoms and red algae were more than 16 and 12 percent lower, respectively, in 2013 compared with 2004 , and the percentage of relative abundance of blue-green algae was more than 26 percent higher in 2013 compared with 2004. Higher algal biovolume was collected in 2013 than 2004 (table 2), and green algal biovolume dominated at about 90 percent (table 3). The percentage of relative abundance of eutrophic diatoms was more than 10 percent higher in 2013 compared with 2004. The higher algal abundance, the change from no green algae to a dominance of green algal biovolume, the presence of euglenoids, and a higher abundance of eutrophic diatoms indicate excess nutrients and a more degraded algal assemblage in 2013 than 2004, which disagrees with the metrics used for the mean bioassessment ranking for algae in 2013.

The numbers of invertebrate species and genera at Jewel Creek were more than 35 percent lower in 2013 than 2004, and diversity was 43 percent lower; however, this was related to about 21 percent lower noninsects. In 2004, the assemblage was about 20-percent isopods (C. intermedia), which tend to be relatively tolerant to pollution, but also 22-percent pollution-moderate riffle beetles (Stenelmis), and 20-percent pollution-tolerant mayflies (B. flavistriga and

B. intercalaris). In 2013, isopods made up about 1 percent of the invertebrate assemblage. Riffle beetles were still important in dominance; instead, pollution-tolerant caddisflies (H. betteni and Cheumatopsyche) made up 60 percent of the invertebrate abundance. The HBI-10 rating was "good" in 2013 and "fair" in 2004 and was in contrast to an unchanged invertebrate mIBI across all sampling years.

Jewel Creek is little more than a connector between two lakes, Linnie Lac and Little Muskego Lake, and it has a small drainage area (table 1). The fish assemblage reflects this position on the landscape; species that are more common in lakes than in small streams are common in Jewel Creek, including Lepomis macrochirus (bluegill), pumpkinseed, and Micropterus salmoides (largemouth bass). Nocomis biguttatus (hornyhead chub) were dominant in all sampling years, with a 34-percent relative abundance in 2004, and higher each year, with a 67-percent relative abundance in 2013. The numbers of fish, species, and native species were more than 53 percent lower in 2013 than in 2004, and diversity was more than 40 percent lower in 2013 than in 2004. In contrast, there were differences in some metrics that indicate a positive response; however, these changes may simply reflect the large loss in fish abundance: the percentage of forage fish tolerant to low
DO decreased by 12 percent, and the percentages of omnivorous fish and pollution-tolerant fish were more than 30 percent lower in 2013 compared with 2004.

Some stressors at Jewel Creek were not characterized because of the lack of water-quality and discharge data. Mean impervious surface increased slightly in this watershed, from 11.5 percent in 2004 to 13 percent in 2013. For stream habitat metrics in 2013, measured silt depth was one-fifth of what it was in 2004 and mean erosion length was more than double what it was in 2004, both indicating possible high flows at some point between the two sampling years, such as the July 2010 flooding in southeastern Wisconsin.

At most of the sampled streams, there are indications of adverse changes in the aquatic communities and many stressors linked to urban runoff. Increases in urban runoff as more land is developed, resulting in larger discharges, were also noted by Thomas and others (2007). For the period from October 1, 2003, to September 30, 2004, Thomas and others determined that annual mean discharges were greater than long-term annual mean discharges at many of these sites with long-term discharge records. The greatest differences were detected at the Milwaukee River at Milwaukee (84 percent), Milwaukee River near Cedarburg (56 percent), Menomonee River at Menomonee Falls (47 percent), and Menomonee River at Wauwatosa (44 percent) sites.

\section{Summary and Conclusions}

Aquatic communities including algal, invertebrate, and fish (biota) assemblages were sampled at 14 stream sites in the Milwaukee metropolitan area by the U.S. Geological Survey (USGS) in cooperation with the Milwaukee Metropolitan Sewerage District in 2004-13. Physical characteristics (stream habitat, flow at gaged sites) and chemical characteristics (water quality) were also assessed. In addition, passive samplers (semipermeable membrane devices) were deployed at a subset of six sites to assess potential toxicity to biota from synthetic organic chemicals. The objectives of aquatic community sampling were to assess the ecological status of aquatic communities and potential environmental stressors to gain a better understanding of overall stream conditions in the Milwaukee area.

The taxonomic richness (total number of different kinds) of each assemblage in the aquatic communities provided some insight into the ecological health of each site; however, additional measures or metrics, such as indexes of biotic integrity for each group of biota, yielded more complete assessments. For a subset of three sites where additional temporal sampling was done in spring and early fall in 2011-13, higher numbers of algal taxa were detected in fall compared with spring, indicating fall as an important time for sampling after algal assemblages have had adequate time to develop. Taxonomic signatures indicated that, in general, spring samples from sites aligned more with other samples from the same site than with 
other sites and indicated that variation was greater between sites than within sites for these two times of year. In addition, fall samples collected during temporal sampling aligned most with the sampled sites than with other sites and affirmed the ability to distinguish sites.

In aggregate bioassessments, algal, invertebrate, and fish rankings sometimes assigned different quality to a site based on metric outcomes. Rankings at three sites were worse for invertebrates than for fish, and rankings at four sites were worse for fish than for invertebrates. There were two sites that ranked worse for algae than for invertebrates or fish. This finding underscores differences in environmental tolerances between groups of biota and the importance of carefully selecting biological measures or metrics computed for each group in assessments. For 2013 and for 2004, aggregate bioassessment rankings across all groups of biota indicated the least degraded water quality at Milwaukee River near Cedarburg, Wisconsin (USGS station 04086600); Menomonee River at Menomonee Falls, Wis. (USGS station 04087030); Jewel Creek at Muskego, Wis. (USGS station 05544371); and Milwaukee River at Milwaukee, Wis. (USGS station 04087000). The aggregate bioassessment rankings for Honey Creek at Wauwatosa, Wis. (USGS station 04087119); and Oak Creek at South Milwaukee, Wis. (USGS station 04087204), were better in 2013 than in 2004. The aggregate assessment rankings for Menomonee River at Wauwatosa, Wis. (USGS station 04087120), and Root River at Grange Avenue at Greenfield, Wis. (USGS station 04087214), were worse in 2013 than in 2004; together with Lincoln Creek at 47th Street at Milwaukee, Wis. (USGS station 040869415), and the Kinnickinnic River at South 11th Street at Milwaukee, Wis. (USGS station 04087159), these four sites ranked the lowest for water quality in 2013. In total, from 2004 to 2013, rankings were better at 2 sites, worse at 2 sites, and did not change at 10 sites.

Summary metrics for physical and chemical stressors correlated significantly to biological metrics for algae, invertebrates, and fish, indicating these stressors may be related to adverse effects at some sites. Algal metrics that correlated most to environmental stressors were those related to nutrients, oxygen, salt, and suspended sediment. For invertebrate metrics, the number of Ephemeroptera-Plecoptera-Trichoptera genera; the Hilsenhoff Biotic Index, modified to limit the number of individuals per taxon to 10 for index computation; the macroinvertebrate Index of Biotic Integrity; the percentage of scraper invertebrates; and the mean nutrient tolerance of invertebrate taxa correlated most with environmental stressors. The Index of Biotic Integrity was the fish metric most commonly correlated with the environmental metrics. Stressors reflected an urban signature related to medium and high-intensity developed land, urban land in the 200-foot (60-meter) stream buffer, and higher percentages of impervious surface in the watershed. Rapid runoff from impervious surfaces can damage stream habitat and wash road salt, nutrients, fecal matter, and other chemical contaminants into local streams. Higher percentages of medium and high-intensity developed land, urban land in the stream buffer, and higher percentages of impervious surface in the watershed were all significantly correlated with each other. Potential toxicity from synthetic organic chemicals was detected at all six sites where passive samplers were deployed. Mean chloride concentrations in water were greater than the U.S. Environmental Protection Agency chronic water-quality criterion for the protection of aquatic life in one or more ecological sampling years at several sites. Algal metrics at the 14 sites correlated to fecal coliform, dissolved oxygen, 5-day biological oxygen demand, ammonia nitrogen, zinc, maximum instantaneous discharge per drainage area as an indicator of flood and scour effects, developed land in the watershed (medium and high intensity) and in the stream buffer, impervious surface in the watershed, deciduous and mixed forest, stream open canopy angle, variability of stream depth and bankfull width-to-depth ratio, and substrate embeddedness. The stressors correlated with invertebrate metrics were fecal coliform, 5-day biological oxygen demand, chloride, specific conductance, zinc, total solids, maximum instantaneous discharge (tentatively greater than 40 cubic feet per second per square mile), developed open space, developed land in the watershed (medium and high intensity) and in the stream buffer, impervious surface in the watershed, and stream channel stability. Similar physical and chemical stressors correlated significantly with fish metrics, including fecal coliform; total nonpurgeable dissolved organic carbon; chloride; specific conductance; nitrite; total solids; maximum instantaneous discharge per drainage area; developed open space; developed land in the watershed (low, medium, and high intensity) and in the stream buffer; impervious surface in the watershed; low variability in stream channel morphology (bankfull width-to-depth and velocity-to-depth ratios); and limited riffle habitat that can help mitigate low dissolved oxygen conditions. In summary, these results underscore the effects of urban developed land through runoff from impervious surfaces with subsequent harm to aquatic communities of nearby waterways; however, algal results indicated that as little as 1-percent mixed forest in a watershed might be beneficial with regard to salt runoff in streams.

Long-term monitoring of aquatic communities coupled with physical and chemical data collected with sufficient frequency proved highly useful in evaluating the ecological status of aquatic communities and overall stream condition at the 14 sites. Because of variability that can occur in any single year, long-term monitoring is needed to fully understand the dynamics of any trends that may be occurring at these sites. This combination of biological, physical, and chemical data also provided insight into the environmental stressors that may be contributing to the ecological status and that may be removed or lessened with stream rehabilitation and changes in watershed management. Looking forward, a better understanding of the relative importance of different stressors at sites in a watershed or region can be key to finding ways to minimize degradation at area streams during earlier stages of transition to developed urban land. 


\section{References Cited}

Alvarez, D.A., 2010, Guidelines for the use of the semipermeable membrane device (SPMD) and the polar organic chemical integrative sampler (POCIS) in environmental monitoring studies: U.S. Geological Survey Techniques and Methods, book 1, chap. D4, 28 p. [Also available at https://doi.org/10.3133/tm1D4.]

Alvarez, D.A., Cranor, W.L., Perkins, S.D., Clark, R.C., and Smith, S.B., 2008, Chemical and toxicological assessment of organic contaminants in surface water using passive samplers: Journal of Environmental Quality, v. 37, no. 3, p. 1024-1033. [Also available at https://doi.org/10.2134/ jeq2006.0463.]

Ang, C.Y., Inouye, L.S., McCant, D.D., and McFarland, V.A., 2000, Protocols for a rapid clean-up/extraction procedure and an improved P450RGS dioxin screening assay for sediments: Vicksburg, Miss., U.S. Army Engineer Research and Development Center, DOER Technical Notes Collection (ERDC TN-DOER-C10), 28 p.

Arar, E.J., and Collins, G.B., 1997, U.S. Environmental Protection Agency method 445.0 - In vitro determination of chlorophyll a and pheophytin a in marine and freshwater algae by fluorescence, revision 1.2: Cincinnati, Ohio, U.S. Environmental Protection Agency, National Exposure Research Laboratory, Office of Research and Development, $22 \mathrm{p}$.

Arnold, C.L., Jr., and Gibbons, C.J., 1996, Impervious surface coverage - The emergence of a key environmental indicator: Journal of the American Planning Association, v. 62, no. 2, p. 243-258. [Also available at https://doi.org/10.1080/ 01944369608975688.]

Bahls, L.L., 1993, Periphyton bioassessment methods for Montana streams: Helena, Mont., Montana Water Quality Bureau, Department of Health and Environmental Sciences, $69 \mathrm{p}$.

Baldwin, A.K., Corsi, S.R., Lutz, M.A., Ingersoll, C.G., Dorman, R., Magruder, C., and Magruder, M., 2017, Primary sources and toxicity of PAHs in Milwaukeearea streambed sediment: Environmental Toxicology and Chemistry, v. 36, no. 6, p. 1622-1635. [Also available at https://doi.org/10.1002/etc.3694.]

Baldwin, A.K., Corsi, S.R., Richards, K.D., Geis, S.W., and Magruder, C., 2013, Organic waste compounds in streamsOccurrence and aquatic toxicity in different stream compartments, flow regimes, and land uses in southeast Wisconsin, 2006-9: U.S. Geological Survey Scientific Investigations Report 2013-5104, 46 p., accessed December 9, 2019, at https://doi.org/10.3133/sir20135104.
Barbour, M.T., Gerritsen, J., Snyder, B.D., and Stribling, J.B., 1999, Rapid bioassessment protocols for use in wadeable streams and rivers - Periphyton, benthic macroinvertebrates, and fish ( $2 \mathrm{~d}$ ed.): Washington, D.C., U.S. Environmental Protection Agency, Office of Water, EPA 841-B-99-002, variously paged. [Also available at https://www3.epa.gov/region1/npdes/merrimackstation/ pdfs/ar/AR-1164.pdf.]

Bjørseth, A., and Ramdahl, T., 1985, Sources and emissions of PAH, chap. 1 of Bjørseth, A., and Ramdahl, T., eds., Handbook of polycyclic aromatic hydrocarbons-Emission sources and recent progress in analytical chemistry, v. 2: New York, Marcel Dekker, Inc., p. 1-20.

Britton, L.J., and Greeson, P.W., eds., 1987, Methods for collection and analysis of aquatic biological and microbiological samples: U.S. Geological Survey Techniques of WaterResources Investigations, book 5, chap. A4, p. 139-140.

Bryant, W.L., Jr., and Goodbred, S.L., 2009, The response of hydrophobic organics and potential toxicity in streams to urbanization of watersheds in six metropolitan areas of the United States: Environmental Monitoring and Assessment, v. 157, p. 419-447. [Also available at https://doi.org/ 10.1007/s10661-008-0546-5.]

Buck, O., Niyogi, D.K., and Townsend, C.R., 2004, Scaledependence of land use effects on water quality of streams in agricultural catchments: Environmental Pollution, v. 130, no. 2, p. 287-299. [Also available at https://doi.org/10.1016/ j.envpol.2003.10.018.]

Bunte, K., and Abt, S.R., 2001, Sampling surface and subsurface particle-size distributions in wadable gravel- and cobble-bed streams for analyses in sediment transport, hydraulics, and streambed monitoring: Fort Collins, Colo., U.S. Department of Agriculture, Forest Service, Rocky Mountain Research Station, General Technical Report RMRS-GTR-74, 428 p.

California Stormwater Quality Association, 2015, Zinc sources in California urban runoff (revised April 2015): California Stormwater Quality Association, 63 p., accessed September 6, 2017, at https://www.casqa.org/sites/default/ files/library/technical-reports/zinc_sources_in_california_ urban_runoff.pdf.

Carter, J.L., and Fend, S.V., 2005, Setting limits-The development and use of factor-ceiling distributions for an urban assessment using macroinvertebrates, in Brown, L.R., Gray, R.H., Hughes, R.M., and Meador, M.R., eds., Effects of urbanization on stream ecosystems: Bethesda, Md., American Fisheries Society Symposium 47, p. 179-192. 
Carter, J.L., Purcell, A.H., Fend, S.V., and Resh, V.H., 2009, Development of a local-scale urban stream assessment method using benthic macroinvertebrates-An example from the Santa Clara Basin, California: Journal of the North American Benthological Society, v. 28, no. 4, p. 1007-1021. [Also available at https://doi.org/10.1899/08-159.1.]

Clarke, K.R., and Gorley, R.N., 2006, PRIMER v6-User's manual/tutorial: Plymouth, United Kingdom, Primer-E Ltd., 192 p.

Clarke, K.R., and Warwick, R.M., 2001, Change in marine communities - An approach to statistical analysis and interpretation ( $2 \mathrm{~d}$ ed.): Plymouth, United Kingdom, Primer-E Ltd., variously paged.

Coles, J.F., Bell, A.H., Scudder, B.C., and Carpenter, K.D., 2009, The effects of urbanization and other environmental gradients on algal assemblages in nine metropolitan areas across the United States: U.S. Geological Survey Scientific Investigations Report 2009-5022, 18 p., accessed December 9, 2019, at https://doi.org/10.3133/sir20095022.

Coles, J.F., McMahon, G., Bell, A.H., Brown, L.R., Fitzpatrick, F.A., Scudder Eikenberry, B.C., Woodside, M.D., Cuffney, T.F., Bryant, W.L., Cappiella, K., FraleyMcNeal, L., and Stack, W.P., 2012, Effects of urban development on stream ecosystems in nine metropolitan study areas across the United States: U.S. Geological Survey Circular 1373, 138 p. [Also available at https://doi.org/ 10.3133/cir1373.]

Corsi, S.R., De Cicco, L.A., Lutz, M.A., and Hirsch, R.M., 2015, River chloride trends in snow-affected urban watersheds-Increasing concentrations outpace urban growth rate and are common among all seasons: The Science of the Total Environment, v. 508, p. 488-497. [Also available at https://doi.org/10.1016/j.scitotenv.2014.12.012.]

Corsi, S.R., Graczyk, D.J., Geis, S.W., Booth, N.L., and Richards, K.D., 2010, A fresh look at road saltAquatic toxicity and water-quality impacts on local, regional, and national scales: Environmental Science \& Technology, v. 44, no. 19, p. 7376-7382. [Also available at https://doi.org/10.1021/es101333u.]

Daniel, E., 2017, Underwood Creek in Wauwatosa is getting a makeover: Milwaukee Magazine, March 27, 2017, accessed December 9, 2019, at https://www.milwaukeemag.com/ underwood-creek-wauwatosa-getting-makeover/.

Data Description, Inc., 1996, Data Desk, version 6.1: Ithaca, N.Y., Data Description, Inc.

Davis, A.P., Shokouhian, M., and Ni, S., 2001, Loading estimates of lead, copper, cadmium, and zinc in urban runoff from specific sources: Chemosphere, v. 44, no. 5, p. 997-1009. [Also available at https://doi.org/10.1016/ S0045-6535(00)00561-0.]
Epping Overholt, G., 2014, Taking back our rivers! in Morgan, K., ed., Rivers Report, Spring 2014: Milwaukee, Wis., Southeastern Wisconsin Watersheds Trust, Inc., (Sweet Water) and University of Wisconsin-Extension, 8 p.

Fitzpatrick, F.A., Waite, I.R., D’Arconte, P.J., Meador, M.R., Maupin, M.A., and Gurtz, M.E., 1998, Revised methods for characterizing stream habitat in the National Water-Quality Assessment program: U.S. Geological Survey WaterResources Investigations Report 98-4052, 67 p. [Also available at https://doi.org/10.3133/wri984052.]

Heiskary, S.A., and Bouchard, R.W., Jr., 2015, Development of eutrophication criteria for Minnesota streams and rivers using multiple lines of evidence: Freshwater Science, v. 34, no. 2, p. 574-592. [Also available at https://doi.org/ 10.1086/680662.]

Hilsenhoff, W.L., 1982, Using a biotic index to evaluate water quality in streams: Madison, Wis., Wisconsin Department of Natural Resources, Technical Bulletin 132, 22 p.

Hilsenhoff, W.L., 1987, An improved biotic index of organic stream pollution: Great Lakes Entomologist, v. 20, no. 1, p. 31-39.

Hilsenhoff, W.L., 1998, A modification of the biotic index of organic stream pollution to remedy problems and permit its use throughout the year: Great Lakes Entomologist, v. 31, no. 1, p. 1-12.

Hohensinner, S., Hauer, C., and Muhar, S., 2018, River morphology, channelization, and habitat restoration, chap. 3 of Schmutz, S., and Sendzimir, J., eds., Riverine ecosystem management-Science for governing towards a sustainable future: Switzerland, Springer, Aquatic Ecology Series, v. 8, p. 41-65, accessed July 25, 2019, at https://doi.org/10.1007/ 978-3-319-73250-3_3.

Johnson, B.T., Petty, J.D., Huckins, J.N., Lee, K., and Gauthier, J., 2004, Hazard assessment of a simulated oil spill on intertidal areas of the St. Lawrence River with SPMD-TOX: Environmental Toxicology, v. 19, no. 4, p. 329-335. [Also available at https://doi.org/10.1002/ tox.20022.]

Judd, J.H., 1970, Lake stratification caused by runoff from street deicing: Water Research, v. 4, no. 8, p. 521-532. [Also available at https://doi.org/10.1016/00431354(70)90002-3.]

Karr, J.R., 1981, Assessment of biotic integrity using fish communities: Fisheries (Bethesda, Md.), v. 6, no. 6, p. 21-27. [Also available at https://doi.org/10.1577/15488446(1981)006\%3C0021:AOBIUF\%3E2.0.CO;2.]

Karr, J.R., and Chu, E.W., 1999, Restoring life in running waters-Better biological monitoring: Washington, D.C., Island Press, 206 p. 
Lange-Bertalot, H., 1979, Pollution tolerance of diatoms as a criterion for water quality estimation: Nova Hedwigia, v. 64, p. $285-304$.

Lenat, D.R., 1988, Water quality assessment of streams using a qualitative collection method for benthic macroinvertebrates: Journal of the North American Benthological Society, v. 7, no. 3, p. 222-233. [Also available at https://doi.org/10.2307/1467422.]

Lyons, J., 1992, Using the Index of Biotic Integrity (IBI) to measure environmental quality in warmwater streams of Wisconsin, General Technical Report NC-149: St. Paul, Minn., U.S. Department of Agriculture, Forest Service, North Central Experiment Station, 51 p.

Mahler, B.J., Van Metre, P.C., Bashara, T.J., Wilson, J.T., and Johns, D.A., 2005, Parking lot sealcoat-An unrecognized source of urban polycyclic aromatic hydrocarbons: Environmental Science \& Technology, v. 39, no. 15, p. 5560-5566. [Also available at https://doi.org/10.1021/ es0501565.]

McMahon, T.E., 1982, Habitat suitability index modelsCreek chub: U.S. Fish and Wildlife Service Report FWS/ OBS-82/10.4, 32 p., accessed October 24, 2017, at https://archive.usgs.gov/archive/sites/www.nwrc.usgs.gov/ wdb/pub/hsi/hsi-004.pdf.

Merritt, R.W., and Cummins, K.W., 1996, An introduction to the aquatic insects of North America 3rd ed.: Dubuque, Iowa, Kendall/Hunt Publishing Company, 862 p.

Milwaukee Journal Sentinel, 2017, Milwaukee Common Council moves to ban coal-tar sealants: Journal Sentinel, January 29, 2017, accessed July 25, 2019, at https://www.jsonline.com/story/news/local/milwaukee/ 2017/01/29/milwaukee-common-council-moves-ban-coaltar-sealants/97098666/.

Milwaukee Metropolitan Sewerage District, 2004, State of the watershed-Menomonee River watershed: Milwaukee, Wis., Milwaukee Metropolitan Sewerage District, Report WQI 04, 18 p.

Milwaukee Metropolitan Sewerage District, 2005, State of the watershed - Root River watershed: Milwaukee, Wis., Milwaukee Metropolitan Sewerage District, Report WQI 03-008-1, $18 \mathrm{p}$.

Milwaukee Metropolitan Sewerage District, 2013, Water quality monitoring data summary statistics report 2013: Milwaukee, Wis., Milwaukee Metropolitan Sewerage District, 459 p., accessed July 25, 2019, at https://www.mmsd.com/application/files/1714/8477/9860/ WQSummaryStatistics2013.pdf
Milwaukee Metropolitan Sewerage District, 2020, Kinnickinnic River flood management: Milwaukee Metropolitan Sewerage District web page, accessed April 6, 2020, at https://www.mmsd.com/what-we-do/floodmanagement/kinnickinnic-river.

Moulton, S.R., II, Kennen, J.G., Goldstein, R.M., and Hambrook, J.A., 2002, Revised protocols for sampling algal, invertebrate, and fish communities as part of the National Water-Quality Assessment Program: U.S. Geological Survey Open-File Report 02-150, 75 p. [Also available at https://doi.org/10.3133/ofr2002150.]

National Institute of Environmental Health Sciences, 2017, Dioxins: National Institute of Environmental Health Sciences web page, accessed December 12, 2017, at https://www.niehs.nih.gov/health/topics/agents/dioxins/ index.cfm.

National Weather Service, 2010, Flash flooding/heavy rain event \& tornado outbreak, July 22, 2010: National Oceanic and Atmospheric Administration web page, accessed December 9, 2019, at https://www.weather.gov/mkx/ 072210_flashflooding-tornadoes.

Paul, M.J., and Meyer, J.L., 2001, Streams in the urban landscape: Annual Review of Ecology and Systematics, v. 32, no. 1, p. 333-365. [Also available at https://doi.org/10.1146/ annurev.ecolsys.32.081501.114040.]

Peters, C.A., Robertson, D.M., Saad, D.A., Sullivan, D.J., Scudder, B.C., Fitzpatrick, F.A., Richards, K.D., Stewart, J.S., Fitzgerald, S.A., and Lenz, B.N., 1998, Water quality in the Western Lake Michigan Drainages, Wisconsin and Michigan, 1992-95: U.S. Geological Survey Circular 1156, 40 p. [Also available at https://doi.org/10.3133/cir1156.]

Porter, S.D., 2008, Algal attributes-An autecological classification of algal taxa collected by the National Water-Quality Assessment Program: U.S. Geological Survey Data Series 329, 22 p., accessed December 9, 2019, at https://doi.org/ $10.3133 / \mathrm{ds} 329$.

Porter, S.D., Mueller, D.K., Spahr, N.E., Munn, M.D., and Dubrovsky, N.M., 2008, Efficacy of algal metrics for assessing nutrient and organic enrichment in flowing waters: Freshwater Biology, v. 53, no. 5, p. 1036-1054. [Also available at https://doi.org/10.1111/j.1365-2427.2007.01951.x.]

Potapova, M., and Charles, D.F., 2007, Diatom metrics for monitoring eutrophication in rivers of the United States: Ecological Indicators, v. 7, no. 1, p. 48-70. [Also available at https://doi.org/10.1016/j.ecolind.2005.10.001.]

Rantz, S.E., and others, 1982, Measurement and computation of streamflow, v. 1 and 2: U.S. Geological Survey WaterSupply Paper 2175, 631 p., accessed March 14, 2019, at https://doi.org/10.3133/wsp2175. 
Richards, K.D., Scudder, B.C., Fitzpatrick, F.A., Steuer, J.J., Bell, A.H., Peppler, M.C., Stewart, J.S., and Harris, M.A., 2010, Effects of urbanization on stream ecosystems along an agriculture-to-urban land-use gradient, Milwaukee to Green Bay, Wisconsin, 2003-2004: U.S. Geological Survey Scientific Investigations Report 2006-5101-E, 210 p. [Also available at https://doi.org/10.3133/sir20065101E.]

Robertson, D.M., Graczyk, D.J., Garrison, P.J., Wang, L., LaLiberte, G., and Bannerman, R., 2006, Nutrient concentrations and their relations to the biotic integrity of wadable streams in Wisconsin: U.S. Geological Survey Professional Paper 1722, 139 p. [Also available at https://doi.org/ 10.3133/pp1722.]

Roy, A.H., Freeman, M.C., Freeman, B.J., Wenger, S.J., Ensign, W.E., and Meyer, J.L., 2006, Importance of riparian forests in urban catchments contingent on sediment and hydrologic regimes: Environmental Management, v. 37, no. 4, p. 523-539. [Also available at https://doi.org/10.1007/ s00267-005-0029-1.]

Russo, R.C., and Thurston, R.V., 1977, The acute toxicity of nitrite to fishes, in Tubb, R.A., ed., Recent advances in fish toxicology-A symposium: Corvallis, Oreg., U.S. Environmental Protection Agency, Report EPA-600/3-77-085, 203 p.

Sauer, E.P., Vandewalle, J.L., Bootsma, M.J., and McLellan, S.L., 2011, Detection of the human specific Bacteroides genetic marker provides evidence of widespread sewage contamination of stormwater in the urban environment: Water Research, v. 45, no. 14, p. 4081-4091. [Also available at https://doi.org/10.1016/j.watres.2011.04.049.]

Schneider, M.A., Lutz, M.A., and others, 2004, Waterresources-related information for the Milwaukee Metropolitan Sewerage District planning area, Wisconsin, 1970-2002: U.S. Geological Survey Water-Resources Investigations Report 2003-4240, 288 p. [Also available at https://doi.org/10.3133/wri034240.]

Schueler, T.R., 1994, The importance of imperviousness: Watershed Protection Techniques, v. 1, no. 3, p. 100-111.

Scudder Eikenberry, B.C., Bell, A.H., Sullivan, D.J., Lutz, M.A., and Alvarez, D.A., 2010, Biological waterquality assessment of selected streams in the Milwaukee Metropolitan Sewerage District Planning Area of Wisconsin, 2007 (ver. 1.1, February 2014): U.S. Geological Survey Scientific Investigations Report 2010-5166, 28 p., accessed December 9, 2019, at https://doi.org/10.3133/ $\operatorname{sir} 20105166$.
Scudder Eikenberry, B.C., Nott, M.A., Stewart, J.S., Sullivan, D.J., Fitzpatrick, F.A., Bell, A.H., and Olds, H.T., 2020, Aquatic community and environmental data for 14 rivers and streams in the Milwaukee Metropolitan Sewerage District Planning Area, 2004-13: U.S. Geological Survey data release, https://doi.org/10.5066/P9FWMODL.

Shannon, C.E., 1948, A mathematical theory of communication: The Bell System Technical Journal, v. 27, no. 3, p. 379-423. [Also available at https://doi.org/10.1002/ j.1538-7305.1948.tb01338.x.]

Siddiqi, M.A., Laessig, R.H., and Reed, K.D., 2003, Polybrominated Diphenyl Ethers (PBDEs) - New Pollutants-Old Diseases: Clinical Medicine \& Research, v. 1, no. 4, p. 281-290. [Also available at https://doi.org/ 10.3121/cmr.1.4.281.]

Simonson, T.D., Lyons, J., and Kanehl, P.D., 1993, Guidelines for evaluating fish habitat in Wisconsin streams: U.S. Forest Service, North Central Forest Experiment Station, General Technical Report NC-164, 36 p. [Also available at https:/www.nrs.fs.fed.us/pubs/gtr/gtr_nc164.pdf.]

Southeastern Wisconsin Regional Planning Commission, Milwaukee Metropolitan Sewerage District, Wisconsin Department of Natural Resources, and U.S. Geological Survey, 2007, A regional water quality management plan update for the Greater Milwaukee Watersheds (amended May 2013): Waukesha, Wis., SEWRPC Planning Report no. 50, part one, chap. 1-12, 1305 p. plus appendixes, accessed March 15, 2019, at https://www.sewrpc.org/SEWRPC/Environment/RegionalWaterQualityManagement.htm.

Sullivan, D.J., 1997, Fish communities of fixed sites in the Western Lake Michigan Drainages, Wisconsin and Michigan, 1993-95: U.S. Geological Survey WaterResources Investigations Report 95-4211-C, 23 p. [Also available at https://doi.org/10.3133/wri954211C.]

Templar, H.A., Dila, D.K., Bootsma, M.J., Corsi, S.R., and McLellan, S.L., 2016, Quantification of human-associated fecal indicators reveal sewage from urban watersheds as a source of pollution to Lake Michigan: Water Research, v. 100, p. 556-567. [Also available at https://doi.org/ 10.1016/j.watres.2016.05.056.]

Thomas, J.C., Lutz, M.A., Bruce, J.L., Graczyk, D.J., Richards, K.D., Krabbenhoft, D.P., Westenbroek, S.M., Scudder, B.C., Sullivan, D.J., and Bell, A.H., 2007, Water-quality characteristics for selected sites within the Milwaukee Metropolitan Sewerage District planning area, Wisconsin, February 2004-September 2005: U.S. Geological Survey Scientific Investigations Report 2007-5084, 187 p. [Also available at https://doi.org/ $10.3133 / \operatorname{sir} 20075084$. 
Trask, P.D., 1932, Origin and environment of source sediments in petroleum: Houston, Tex., Gulf Publishing Company, $324 \mathrm{p}$.

University of Wisconsin-Extension and Wisconsin Department of Natural Resources, 1997, Polluted urban runoff-A source of concern: Madison, Wis., University of WisconsinExtension, 4 p., accessed March 15, 2019, at http://cleanwater.uwex.edu/pubs/pdf/urban.pdf.

U.S. Environmental Protection Agency, 1988, Ambient water quality criteria for chloride-1988: U.S. Environmental Protection Agency Report EPA440/5-88-001, 39 p., accessed April 7, 2020, at https:/www.epa.gov/sites/ production/files/2018-08/documents/chloride-aquatic-lifecriteria-1988.pdf.

U.S. Environmental Protection Agency, 1997, Urbanization and streams - Studies of hydrological impacts: Washington, D.C., U.S. Environmental Protection Agency Report EPA 841-R-97-009, 6 p. plus appendixes.

U.S. Environmental Protection Agency, 2006, Protecting water resources with higher-density development: Washington, D.C., U.S. Environmental Protection Agency Report EPA 231-R-06-001, 38 p., accessed December 28, 2007, at https://www.epa.gov/sites/production/files/2014-03/ documents/protect_water_higher_density1.pdf.

U.S. Environmental Protection Agency, 2010, EPA finishes cleanup on Little Menomonee River: U.S. Environmental Protection Agency Fact Sheet, 4 p., accessed July 25, 2019, at https://nepis.epa.gov/Exe/ZyPDF.cgi/P100AW3B.PDF? Dockey=P100AW3B.PDF.

U.S. Environmental Protection Agency, 2013, Aquatic life ambient water quality criteria for ammonia-Freshwater 2013: U.S. Environmental Protection Agency, Office of Water, Report EPA 822-R-18-002, 242 p., accessed March 15, 2019, at https://www.epa.gov/wqc/aquatic-lifecriteria-ammonia.

U.S. Environmental Protection Agency, 2014, Case summary — \$23 million settlement reached at the Cedar Creek Superfund alternative site: U.S. Environmental Protection Agency web page, accessed April 7, 2020, at https://www.epa.gov/enforcement/case-summary23-million-settlement-reached-cedar-creek-superfundalternative-site.

U.S. Environmental Protection Agency, 2017, Polybrominated diphenyl ethers: U.S. Environmental Protection Agency, Office of Land and Emergency Management, Technical fact sheet EPA 505-F-17-015, 5 p., accessed April 7, 2020, at https://www.epa.gov/sites/production/files/201403/documents/ffrrofactsheet_contaminant_perchlorate_ january2014_final_0.pdf.
U.S. Geological Survey, 2014, National Land Cover Database: U.S. Geological Survey data release, accessed March 15, 2019, at https://www.sciencebase.gov/catalog/item/ 4f70a43ce4b058caae3f8db3.

U.S. Geological Survey, 2016, USGS water data for the Nation: U.S. Geological Survey National Water Information System database, accessed April 25, 2016, at https://doi.org/ 10.5066/F7P55KJN.

van Dam, H., Mertens, A., and Sinkeldam, J., 1994, A coded checklist and ecological indicator values of freshwater diatoms from the Netherlands: Netherlands Journal of Aquatic Ecology, v. 28, no. 1, p. 117-133. [Also available at https://doi.org/10.1007/BF02334251.]

Van Metre, P.C., Mahler, B.J., and Furlong, E.T., 2000, Urban sprawl leaves its PAH signature: Environmental Science \& Technology, v. 34, no. 19, p. 4064-4070. [Also available at https://doi.org/10.1021/es991007n.]

Van Metre, P.C., Mahler, B.J., and Wilson, J.T., 2009, PAHs underfoot - Contaminated dust from coal-tar sealcoated pavement is widespread in the United States: Environmental Science \& Technology, v. 43, no. 1, p. 20-25. [Also available at https://doi.org/10.1021/es802119h.]

Walsh, C.J., Roy, A.H., Feminella, J.W., Cottingham, P.D., Groffman, P.M., and Morgan, R.P., II, 2005, The urban stream syndrome - Current knowledge and the search for a cure: Journal of the North American Benthological Society, v. 24, no. 3, p. 706-723. [Also available at https://doi.org/ 10.1899/04-028.1.]

Waters, T.E., 1995, Sediment in streams - Sources, biological effects and control: American Fisheries Society (Bethesda, Md.), monograph 7, $251 \mathrm{p}$.

Weigel, B.M., 2003, Development of stream macroinvertebrate models that predict watershed and local stressors in Wisconsin: Journal of the North American Benthological Society, v. 22, no. 1, p. 123-142. [Also available at https://doi.org/10.2307/1467982.]

Williams, D.D., Williams, N.E., and Cao, Y., 2000, Road salt contamination of groundwater in a major metropolitan area and development of a biological index to monitor its impact: Water Research, v. 34, no. 1, p. 127-138. [Also available at https://doi.org/10.1016/S0043-1354(99)00129-3.]

Wisconsin Department of Health Services, 2005, Estabrook Impoundment/Lincoln Park contaminated sediment questions and answers: Madison, Wis., Wisconsin Department of Health Services Fact Sheet, 4 p. [Also available at https://www.dhs.wisconsin.gov/environmental/ lincolnparkfaq53.pdf.] 
Wisconsin Department of Natural Resources, 2013, Remedial Action Plan update for the Milwaukee Estuary Area of Concern: Wisconsin Department of Natural Resources, Office of the Great Lakes, 23 p. plus appendixes. [Also available at https://nr.wi.gov/topic/greatlakes/documents/ MilwaukeeEstuaryRAPUpdate2013.pdf.]

Wisconsin Department of Natural Resources, 2016, Remedial Action Plan update for the Milwaukee Estuary Area of Concern: Wisconsin Department of Natural Resources, Office of the Great Lakes, 17 p. plus appendixes. [Also available at https://nr.wi.gov/topic/GreatLakes/documents/ MilwaukeeAOCRAP2016.pdf.]

Wisconsin Department of Natural Resources, 2019, Wisconsin 2020 Consolidated Assessment and Listing Methodology (WisCALM) - Clean Water Act Section 303(d) and 305(b) Integrated Reporting: Madison, Wis., Wisconsin Department of Natural Resources Guidance 3200-2019-04, 35 p. [Also available at https://dnr.wi.gov/ topic/SurfaceWater/Assessments.html.]
Xian, G., Homer, C., Dewitz, J., Fry, J., Hossain, N., and Wickham, J., 2011, The change of impervious surface area between 2001 and 2006 in the conterminous United States: Photogrammetric Engineering and Remote Sensing, v. 77, no. 8, p. 758-762.

Young, B.M., Fitzpatrick, F.A., and Blount, J.D., 2015, Stream geomorphic and habitat data from a baseline study of Underwood Creek, Wisconsin, 2012: U.S. Geological Survey Data Series 947, 14 p. plus data files, accessed December 9, 2019, at https://doi.org/10.3133/ds947.
For more information about this publication, contact:

Director, USGS Upper Midwest Water Science Center

8505 Research Way

Middleton, WI 53562

608-828-9901

For additional information, visit: https://www.usgs.gov/centers/umid-water

Publishing support provided by the Rolla Publishing Service Center 

